\title{
A Feasibility Assessment of Water Quality Trading in the Greenbrier River Watershed, West Virginia
}

Arun Khatri-Chhetri

West Virginia University

Follow this and additional works at: https://researchrepository.wvu.edu/etd

\section{Recommended Citation}

Khatri-Chhetri, Arun, "A Feasibility Assessment of Water Quality Trading in the Greenbrier River Watershed, West Virginia" (2012). Graduate Theses, Dissertations, and Problem Reports. 4875.

https://researchrepository.wvu.edu/etd/4875

This Dissertation is protected by copyright and/or related rights. It has been brought to you by the The Research Repository @ WVU with permission from the rights-holder(s). You are free to use this Dissertation in any way that is permitted by the copyright and related rights legislation that applies to your use. For other uses you must obtain permission from the rights-holder(s) directly, unless additional rights are indicated by a Creative Commons license in the record and/ or on the work itself. This Dissertation has been accepted for inclusion in WVU Graduate Theses, Dissertations, and Problem Reports collection by an authorized administrator of The Research Repository @ WVU.

For more information, please contact researchrepository@mail.wvu.edu. 


\title{
A Feasibility Assessment of Water Quality Trading in the Greenbrier River Watershed, West Virginia
}

\author{
Arun Khatri-Chhetri
}

Dissertation submitted to the Davis College of Agriculture, Natural Resources, and Design at West Virginia University in partial fulfillment of the requirements for the degree of

Doctor of Philosophy

in

Natural Resource Economics

Dissertation Committee:

Alan R. Collins, Ph.D., Chair

Timothy T. Phipps, Ph.D. Mark Sperow, Ph.D.

Michael P. Strager, Ph.D.

Tatiana Borisova, Ph.D.

Division of Resource Management

Agriculture and Resource Economics Program

Morgantown, West Virginia

2012

Keywords: Water Quality Trading; Water Quality Modeling; Best Management Practices; Non-Point Source; Waste Water Treatment Plant 


\section{ABSTRACT \\ A Feasibility Assessment of Water Quality Trading in the Greenbrier River Watershed, West Virginia}

\section{Arun Khatri-Chhetri}

Current water pollution reduction programs for point and non-point sources have not been completely successful in reducing pollutant discharges thereby meeting the water quality goals specified by the Clean Water Act. The Greenbrier River in West Virginia is one such river where pollutant inflows from point and non-point sources cause severe water quality problems. Many segments of this river are listed as impaired due to high levels of nutrients and bacteria along with benthic and biologic impairment.

The main goal of this dissertation was to assess the physical and economic feasibility of a water quality trading (WQT) program in the Greenbrier River watershed which can reduce the nutrient related water pollution. The focus of this dissertation is the feasibility of nutrient trading between wastewater treatment plants (WWTPs) and farmers in the watershed. This dissertation compares 12 WQT scenarios that include different market design parameters of trading ratios (1:1 and 2:1), effluent limitations for point sources (WWTPs), and baseline requirements for agricultural non-point sources. The physical feasibility analysis includes the estimation of nutrient reduction requirements for the WWTPs (potential demand for nutrient credits) and nutrient reduction potential from the agricultural sources (potential supply of nutrient credits) in the watershed. The economic feasibility analysis includes estimation of costs of credit generation from the agricultural sources, cost of nutrient reduction for the WWTPs, demand for and supply of nutrient credits, cost saving for individual WWTP, and total potential economic benefits from the potential WQT program in the watershed.

A water quality model was developed in using water quality modeling program (MapShed) developed by Evans and Corradini (2011) to estimate the current level of nutrient loads from non-point sources and load reduction potentials from the implementation of best management practices (BMPs) by farmers on the crop and pasture/grass lands. The per unit costs of nutrient reduction from the individual BMPs were estimated based on the USDA NRCS West Virginia payment schedules for the 2012 Environmental Quality Incentive Program (EQIP). Nutrient reduction requirements for WWTPs were estimated based on the most likely effluent 
limitations for the WWTPs in the watershed, their current level of nutrient concentration (mg/l), daily amount of nutrient discharge (lb.), and facility's discharge flow (MGD). The cost estimation model used in the Chesapeake Bay Program for point source treatment plant upgrading was used to estimate total nitrogen (TN) and total phosphorus (TP) reduction costs for WWTP in the Greenbrier River watershed.

The results of this feasibility assessment indicate that the Greenbrier River watershed has potential for a WQT program under certain conditions. The pollutants reduction feasibility study shows that the utilization of TN and TP credits under all targeted TN and TP limits can be met through the implementation of agricultural BMPs on the crop and pasture/grass lands in the watershed. Four market design parameters: effluent limitations for WWTPs, trading ratio between point and non-point sources, baseline requirement for agricultural sources, and market type, had significant impacts on the economic feasibility of the WQT program in the watershed. Some WWTPs, for example Pence Spring and Ronceverte cannot participate in the WQT market at 2:1 trading ratio under the existing BMPs baseline requirement. Similarly, many WWTPs cannot save their compliance costs for WWTP upgrades to meet nutrient standard in nutrient management plan baseline requirement (e.g. Alderson and Ronceverte).

The total potential economic benefit from the WQT program in the watershed was estimated by computing aggregate potential demand and supply curves under 12 scenarios and two markets. Equilibrium prices levels (supply = demand) were computed for TP credits in both single market and combined market, and for $\mathrm{TN}$ in combined market. The equilibrium price of phosphorus in a single nutrient market ranged from \$ 52 to $\$ 239$ per pound of TP while the combined market had a price range of between $\$ 9$ and $\$ 61$ per pound under 12 WQT scenarios. For TN credit prices in a combined market, prices ranged from $\$ 5$ to $\$ 45$ per lb.

The total economic benefits were estimated for a single nutrient market (TP) and combined nutrients market (TP and TN). The goal of each WWTP is to reduce TP. A market for TN credits was included to evaluate the impact of this additional market on decreasing the equilibrium price of TP credits. Results show that single nutrient market is economically feasible at less stringent TP limitations (1.0 and $0.5 \mathrm{mg} / \mathrm{l})$. However, combined nutrients market would be economically feasible at a more stringent TP limitation $(0.1 \mathrm{mg} / \mathrm{l})$. The total economic benefits decrease under the nutrient management plan baseline requirements compared to the total economic benefits under existing BMPs baseline requirements for agricultural sources. Under all 
12 WQT scenarios, total economic benefits were low under the $100 \%$ nutrient management plan baseline requirement. The high trading ratio had negative impact on the total economic benefit. The comparisons of total economic benefits between 1:1 and 2:1 trading ratios in two markets show that the total economic benefits were lower in all WQT scenarios with 2:1 trading ratios. Under all scenarios, the presence of a market (either single or combined) generated more economic benefits than without a market (WWTP upgrades only).

All seven WWTPs in the Greenbrier River could experience a cost savings compared to treatment plant upgrade costs by purchasing either TP and/or TN credits. Five out of seven WWTPs (Union PSD, Town of Alderson, City of White Sulfur Springs, Town of Hillsboro, and City of Marlinton) in the watershed can experience cost saving under most of the WQT scenarios in a WQT market. Very limited WQT scenarios were economically feasible for Pence Springs PSD and City of Ronceverte. The highest cost savings per WWTP (ranging over 90\%) were achieved under a 1:1 trading ratio and using existing BMPs as a baseline requirement. For the seven WWTPs along the Greenbrier River, treatment plant upgrades to meet a $0.5 \mathrm{mg} / \mathrm{l}$ effluent standard for TP was projected to cost about $\$ 2.5$ million annually. The percentage of cost savings from the participation in a single market in the watershed ranged from $1 \%$ to $48 \%$ under different baseline requirements and trading ratios. The cost savings from the participation in a combined nutrients market in the watershed was about $61 \%$ under the existing BMPs baseline requirement and 1:1 trading ratio. This cost saving was about 37\% under the existing BMPs baseline requirement and 2:1 trading ratio.

These results provide important information in order to create a viable WQT program in the Greenbrier River watershed. The information generated from the water quality model can be used in the development of TMDLs and nutrient reduction standards, and selection of BMPs eligible to generate credits. The choice of baseline requirements for agricultural sources, trading ratio between agricultural sources and WWTPs, and TN and TP limitations for WWTPs will have great impacts on the economic and environmental outcomes of any WQT program. Baseline requirements, in particular, will determine whether a single TP market is viable (only under a current BMP baseline) or whether a combined market with enforced effluent standards and credits being available for both $\mathrm{TN}$ and $\mathrm{TP}$ is required for a WQT program to exist. 


\section{ACKNOWLEDGEMENTS}

I would especially like to thank my major advisor, Dr. Alan R Collins, for his help and guidance throughout my Ph.D. study in the West Virginia University. Special thanks go to my advisory committee members Dr. Timothy T Phipps, Dr. Mark Sperow, Dr. Michael P Strager, and Dr. Tatiana Borisova for their continued support and guidance for this dissertation. I am grateful to all my friends and professors who had shared their knowledge and ideas in classes and graduate seminars. Thanks also go to U.S. Environmental Protection Agency for research funding and farmers of Greenbrier County, WV for providing valuable information for my research.

Finally, I am extremely gratefully to my wife Nilam Prasai. This Ph.D. would not have been possible without her encouragement, support, and sacrifice. I am also thankful to my son, Nishil Arun KC, and my Mother for their patience and support throughout my study. 


\section{TABLE OF CONTENTS}

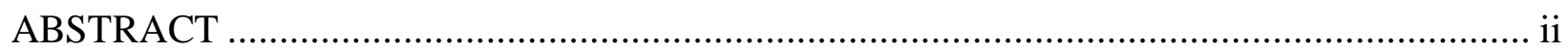

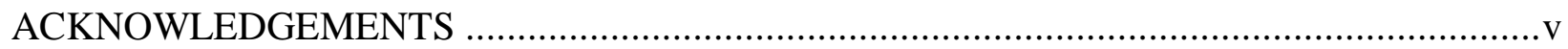

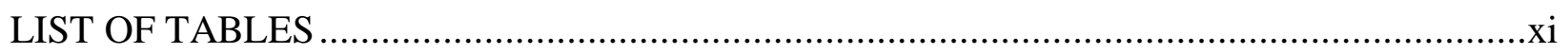

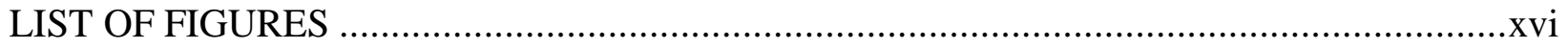

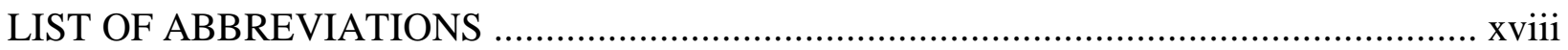

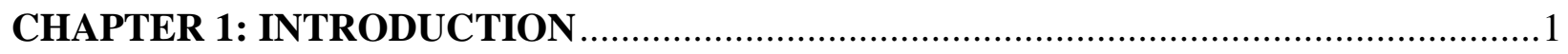

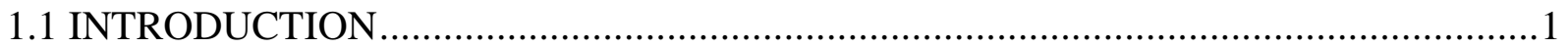

1.2 WATER QUALITY ISSUES IN THE GULF OF MEXICO .........................................

1.3 WATER QUALITY PROBLEMS IN WEST VIRGINIA AND GREENBRIER RIVER ...7

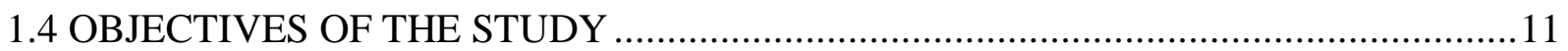

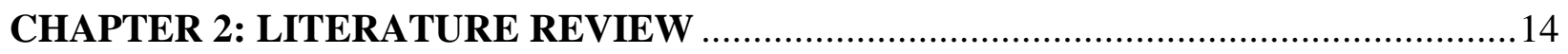

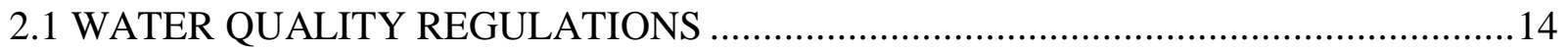

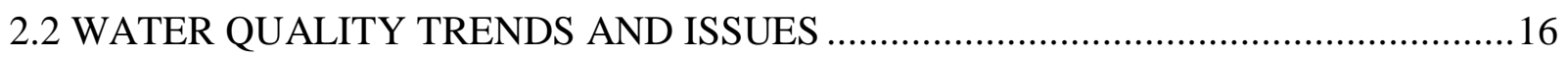

2.3 REQUIREMENTS FOR WATER QUALITY TRADING PROGRAM ...........................18

2.3.1 SETTING WATER QUALITY GOALS ........................................................... 19

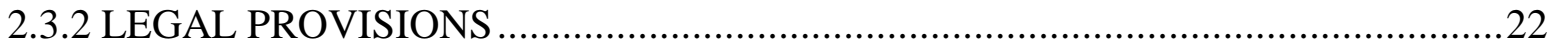

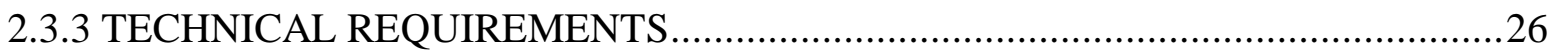

2.4. WQT PROGRAM FEASIBILITY ANALYSIS .....................................................2

2.4.1 SOURCES AND AMOUNTS OF POLLUTION DISCHARGE ............................28

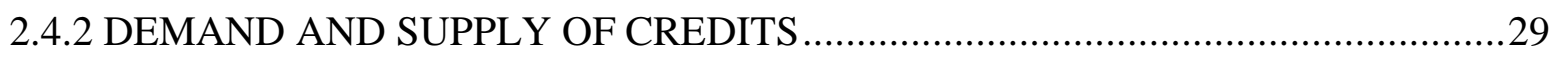

2.5 CURRENT WATER QUALITY TRADING PRACTICES IN THE USA ........................31

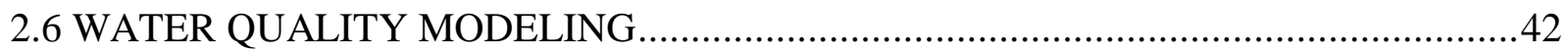


2.6.1 WASP (Water Quality Analysis Simulation Program) ….........................................44

2.6.2 HSPF (Hydrologic Simulation Program-Fortran) .................................................45

2.6.3 SWAT (Soil and Water Assessment Tool) ...........................................................45

2.6.4 SPARROW (SPAtially Referenced Regressions On Watershed attributes)................46

2.6.5 WCMS (Watershed Characterization and Modeling Software) ................................46

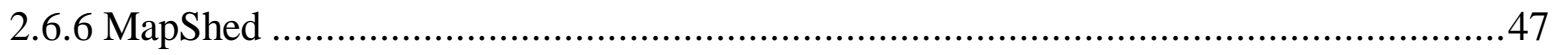

CHAPTER 3: THEORETICAL BACKGROUND AND MODEL ...................................49

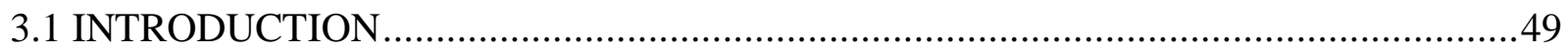

3.2 MARKET-BASED INSTRUMENTS FOR POLLUTION CONTROL ............................49

3.3 THEORETICAL MODEL OF WATER QUALITY TRADING ...................................50

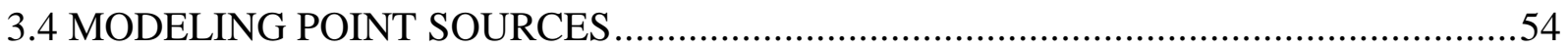

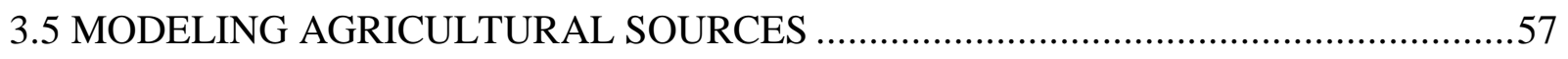

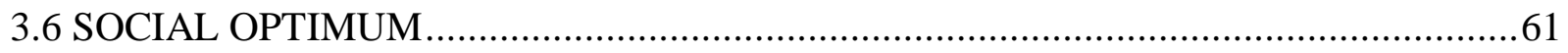

3.7 SINGLE AND COMBINED NUTRIENTS MARKET ……….....................................63

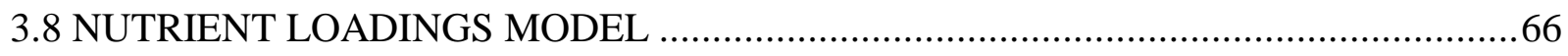

CHAPTER 4: STUDY AREA FOR WQT FEASIBILITY ANALYSIS ...........................68

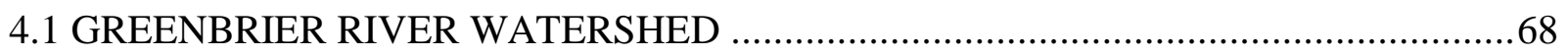

4.2 WATER QUALITY MANAGEMENT IN GREENBRIER RIVER WATERSHED .........71

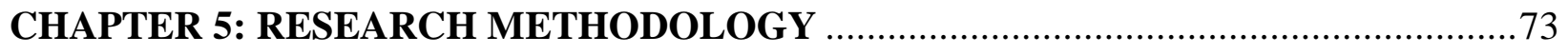

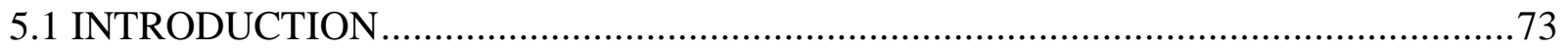

5.2 SURVEY OF AGRICULTURAL BEST MANAGEMENT PRACTICES ........................73

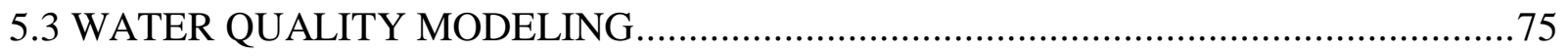

5.3.1 GIS DATA FOR WATER QUALITY MODELING IN THE MAPSHED .................75 
5.3.2 INPUT DATA FOR WATER QUALITY MODELING IN THE MAPSHED .80

5.3.3 WQM ESTIMATION, VALIDATION, AND CALIBRATION .82

5.4. ESTIMATION OF POTENTIAL NUTRIENT CREDIT SUPPLY ...........................8

5.4.1 SELECTION OF BMPS FOR WATER QUALITY MODELING .......................89

5.4.2 ESTIMATION OF TN AND TP CREDIT SUPPLY ....................................... 90

5.4.3 ESTIMATION OF COST OF TN AND TP CREDIT ….................................92

5.5 ESTIMATION OF POTENTIAL NUTRIENT CREDIT DEMAND ...........................93

5.5.1 CURRENT TREATMENT SYSTEM.........................................................93

5.5.2 EXISTING POLLUTANT LOADS ........................................................ 95

5.5.3 ESTIMATION OF NUTRIENTS REDUCTION REQUIREMENT FOR WWTP ....95

5.5.4 ESTIMATION OF NUTRIENTS REDUCTION COSTS FOR WWTP ..................97

5.5.5 ESTIMATION OF COST OF TN AND TP REDUCTION .............................. 100

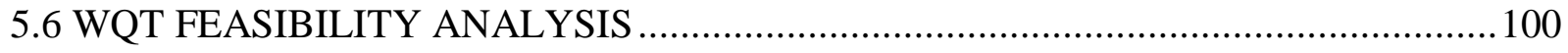

5.7 IMPACT OF EXISTING LEVEL OF BMPS ON THE WQT MARKET ..................... 105

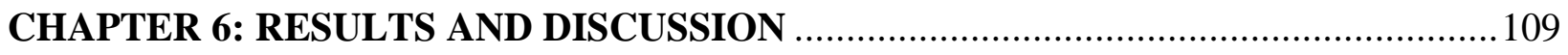

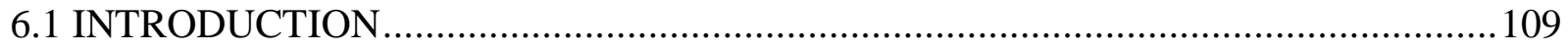

6.2 FARM BEST MANAGEMENT PRACTICES .................................................... 109

6.2.1 CHARACTERISTICS OF RESPONDENTS ................................................. 109

6.2.2 EXISTING LEVELS OF BMPS .......................................................... 111

6.3 EXISTING NUTRIENTS LOADING IN THE GREENBRIER RIVER WATERSHED 116 6.4 POTENTIAL NUTRIENT CREDIT DEMAND .................................................. 125

6.4.1 NUTRIENT LOAD REDUCTION REQUIREMENT ................................... 125

6.4.2 COSTS FOR NUTRIENT REDUCTION ............................................. 127 
6.4.3 POTENTIAL NUTRIENT CREDIT DEMAND 130

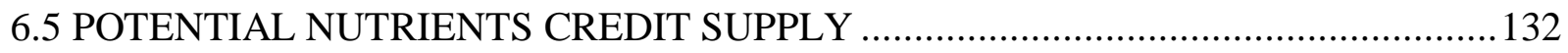

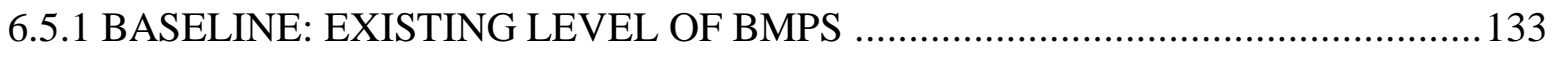

6.5.2 BASELINE: 100\% NUTRIENT MANAGEMENT PLAN_....................................144

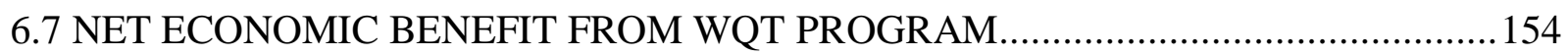

6.8 SINGLE AND COMBINED NUTRIENTS MARKETS FOR WWTP ...........................158

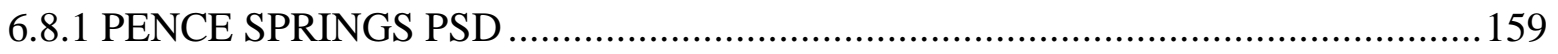

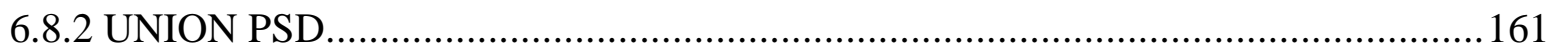

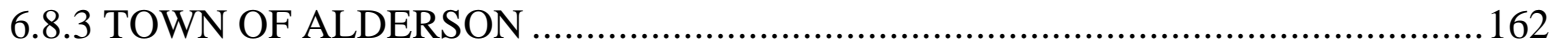

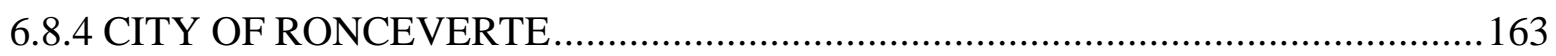

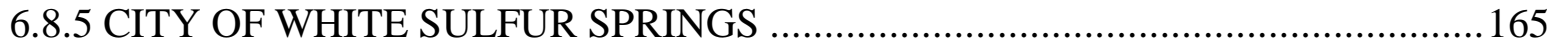

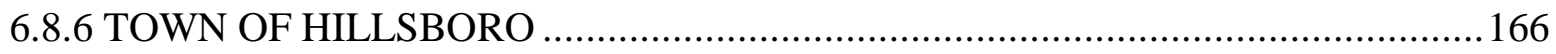

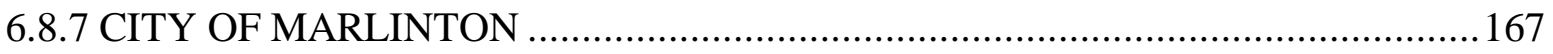

6.9 WQT UNDER THE PROPOSED TP STANDARD BY WVDEP ………………........ 168

6.10 EXISTING BMP, BASELINE REQUIREMENTS, AND WQT MARKET ..................171

6.10.1 NUTRIENTS CREDITS GENERATION ………………................................172

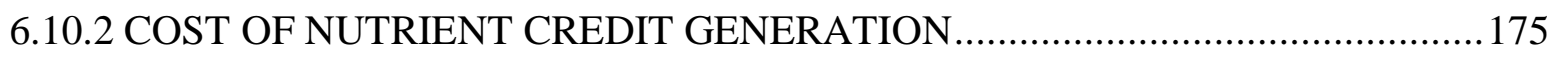

6.10.3 FARMERS PARTICIPATION IN THE WQT MARKET .....................................176

CHAPTER 7: CONCLUSIONS AND POLICY IMPLICATIONS …….......................... 179

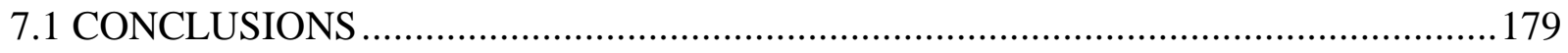

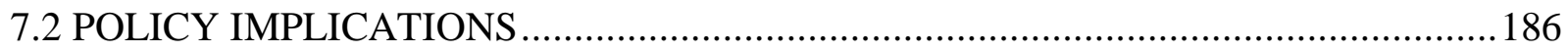

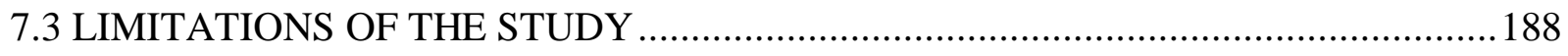

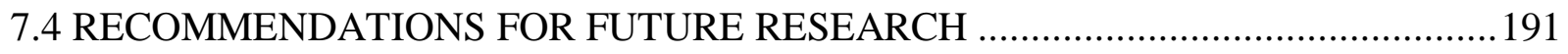


APPENDIX A: THE WCMS MODEL ESTIMATIONS ...............................................2 211

APPENDIX B: COST OF WWTP UPGRADE FOR MEETING DIFFERENT EFFLUENT

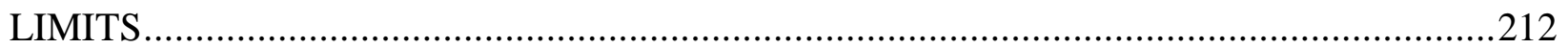

APPENDIX C: POTENTIAL DEMAND AND SUPPLY UNDER 12 WQT SCENAROS AND

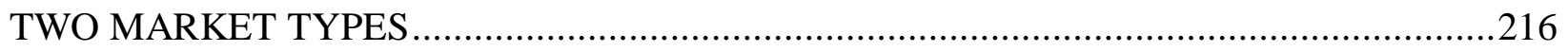

APPENDIX D: SURVEY OF FARM BEST MANAGEMENT PRACTICES IN CROP LAND

APPENDIX E: SURVEY OF FARM BEST MANAGEMENT PRACTICES IN PASTURE

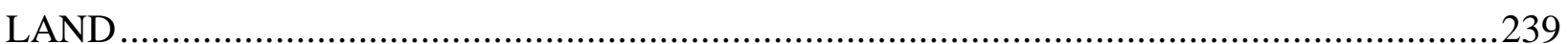




\section{LIST OF TABLES}

Table 2.1: WQT Program by Start Date, State, Water Body and Trading Type ........................32

Table 2.2: WQ Trading Program by Type of Pollutant Trading and Regulatory Drivers ............34

Table 2.3: WQ Trading Program by Total Area, Number of Sources, and Market Structure ......35

Table 2.4: WQ Trading Program by Type of Organization ............................................38

Table 2.5: WQ Trading Program by Type of WQT System and Trading Process ......................39

Table 2.6: WQ Trading Program by Trading Ratio ................................................... 40

Table 2.7: WQ Trading Program by Penalty and Liability ...........................................41

Table 5.1: Overview of GIS data layers prepared for MapShed …...................................75

Table 5.2: Parameters for the Transport File .............................................................. 81

Table 5.3: Parameters for the Nutrient File ........................................................... 82

Table 5.4: BMP Costs and Reduction Efficiencies.......................................................90

Table 5.5: Agricultural Source's Nutrient Credit Supply Scenarios.....................................91

Table 5.6: Summary of CWNS Information for Significant Facilities in the Greenbrier River

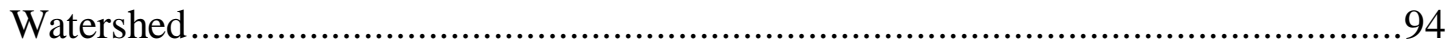

Table 5.7: Existing Nutrient Loads from Permitted NPDES Facilities in the Greenbrier

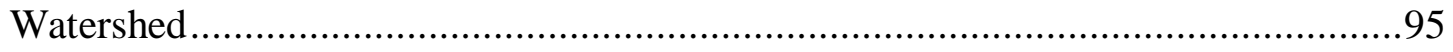

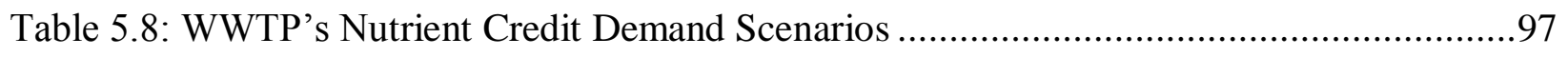

Table 6.1: Type of Land Management based on Survey Responses .................................. 109

Table 6.2: Types of Farm Operations based on Survey Responses .................................. 110

Table 6.3: Percentage of Annual Household Income from Farming (2010) .......................... 111

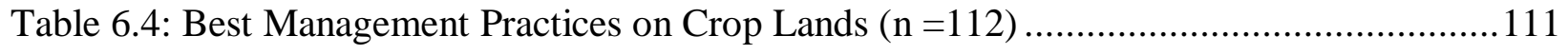

Table 6.5: Interest in Implementing Best Management Practices on the Crop Lands (n=112) ..112 
Table 6.6: Best Management Practices on the Pasture Lands ( $n=66)$.

Table 6.7: Interest in Implementing Best Management Practices on the Pasture Lands (n=66).114

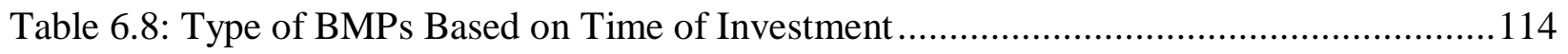

Table 6.9: Existing Level of BMPs Implemented in the Crop and Pasture Lands ................... 116

Table 6.10: Estimated Per Acre Nutrients Discharge from the Agricultural Lands in the Sub-

Watersheds of Greenbrier River Watershed.

Table 6.11: Estimated Existing Nutrient Loads from the Permitted NPDES Facilities in the

Greenbrier Watershed

Table 6.12: Estimated Nutrient Loads Reduction Requirements for Permitted NPDES Facilities in the Greenbrier Watershed 126

Table 6.13: Estimated Nutrient Loads Reduction Requirements for Permitted NPDES Facilities at Sub-Watershed Level

Table 6.14: Estimated Nutrient Reduction Costs for WWTPs in a Single Nutrient Standard .... 127

Table 6.15: Estimated Nutrient Reduction Costs for WWTPs with a Combined Nutrient Standard

Table 6.16: Average Per Unit Cost (\$/lb) of Additional Nutrient Reductions Required for WWTPs to Meet Different Nutrient Limits in a Single (TN or TP) Nutrient Trading Market 129

Table 6.17: Average Per Unit Cost (\$/lb) of Nutrient Reduction for WWTPs to Meet Different Nutrient Limits in Combined (TN and TP) Nutrients Trading Market 130

Table 6.18: Total Pasture and Crop Lands in each Sub-Watershed of Greenbrier River Basin .133 Table 6.19: Potential Nutrient Credits Generation from Agricultural Sources to Meet WWTP Discharge Limits of $8 \mathrm{mg} / \mathrm{TN}$ and $1 \mathrm{mg} / 1 \mathrm{TP}$ at a 1:1 Trading Ratio 134 
Table 6.20: Average per Unit Cost of Nutrient Reduction from BMPs for Crop and

Pasture/Grasslands

Table 6.21: Potential Nutrient Credit Generation from Agricultural Sources to Meet WWTP

Discharge Limits of $5.0 \mathrm{mg} / \mathrm{TN}$ and $0.5 \mathrm{mg} / 1 \mathrm{TP}$ at a $1: 1$ Trading Ratio 138

Table 6.22: Potential Nutrient Credit Generation from Agricultural Sources to Meet WWTP

Discharge Limits of $3 \mathrm{mg} / \mathrm{TN}$ and $0.1 \mathrm{mg} / \mathrm{TP}$ at a 1:1 Trading Ratio

Table 6.23: Potential Nutrient Credit Supply from Agricultural Sources to Meet WWTP

Discharge Limits of $8 \mathrm{mg} / 1 \mathrm{TN}$ and $1 \mathrm{mg} / 1 \mathrm{TP}$ at a $2: 1$ Trading Ratio

Table 6.24: Potential Nutrient Credit Supply from Agricultural Sources to Meet WWTP

Discharge Limits of $5 \mathrm{mg} / 1 \mathrm{TN}$ and $0.5 \mathrm{mg} / 1 \mathrm{TP}$ at a $2: 1$ Trading Ratio

Table 6.25: Potential Nutrient Credit Supply from Agricultural Sources to Meet WWTP

Discharge Limits of $3 \mathrm{mg} / 1 \mathrm{TN}$ and $0.1 \mathrm{mg} / 1 \mathrm{TP}$ at a $2: 1$ Trading Ratio

Table 6.26: Potential Nutrient Credit Supply from Agricultural Sources to Meet WWTP

Discharge Limits of $8 \mathrm{mg} / 1 \mathrm{TN}$ and $1 \mathrm{mg} / 1 \mathrm{TP}$ at a 1:1 Trading Ratio

Table 6.27: Average per Unit Cost of Nutrient Reduction for BMPs on Crop and Pasture/Grass

Lands

Table 6.28: Potential Nutrient Credit Supply from Agricultural Sources to Meet WWTP

Discharge Limits of $5 \mathrm{mg} / 1 \mathrm{TN}$ and $0.5 \mathrm{mg} / 1 \mathrm{TP}$ at a $1: 1$ Trading Ratio .146

Table 6.29: Average per Unit Cost of Nutrient Reduction from BMPs on Crop and Pasture/Grass

Lands

Table 6.30: Potential Nutrient Credit Supply from Agricultural Sources to Meet WWTP

Discharge Limits of $3 \mathrm{mg} / \mathrm{TN}$ and $0.1 \mathrm{mg} / \mathrm{l} \mathrm{TP}$ at a $1: 1$ Trading Ratio 148 
Table 6.31: Average per Unit Cost of Nutrient Reduction from BMPs on Crop and Pasture/Grass Lands

Table 6.32: Potential Nutrient Credit Supply from Agricultural Sources to Meet WWTP

Discharge Limits of $8 \mathrm{mg} / 1 \mathrm{TN}$ and $1 \mathrm{mg} / 1 \mathrm{TP}$ at a $2: 1$ Trading Ratio

Table 6.33: Average per Unit Cost of Nutrient Reduction from BMPs on Crop and Pasture/Grass

Lands 150

Table 6.34: Potential Nutrient Credit Supply from Agricultural Sources to Meet WWTP

Discharge Limits of $5 \mathrm{mg} / 1 \mathrm{TN}$ and $0.5 \mathrm{mg} / \mathrm{l} \mathrm{TP}$ at a $2: 1$ Trading Ratio

Table 6.35: Average per Unit Cost of Nutrient Reduction from BMPs on Crop and Pasture/Grass

Lands

Table 6.36: Potential Nutrient Credit Supply from Agricultural Sources to Meet WWTP

Discharge Limits of $3 \mathrm{mg} / 1 \mathrm{TN}$ and $0.1 \mathrm{mg} / \mathrm{TP}$ at a $2: 1$ Trading Ratio 153

Table 6.37: Average per Unit Cost of Nutrient Reduction from BMPs on Crop and Pasture/Grass Lands .154

Table 6.38: Net Economic Benefit at $1.0 \mathrm{mg} / \mathrm{l} \mathrm{TP}$ Standard in Single and Combined Markets .155

Table 6.39: Net Economic Benefit at $0.5 \mathrm{mg} / \mathrm{l} \mathrm{TP}$ Standard in Single and Combined Markets . 156

Table 6.40: Net Economic Benefit at $0.1 \mathrm{mg} / \mathrm{l} \mathrm{TP}$ Standard in Single and Combined Market... 157

Table 6.41: Equilibrium Nutrient Credit Prices for the 12 WQT Scenarios .159

Table 6.42: Cost of Treatment Facility Upgrade to meet TP Limits and Cost of Credits Purchase in Single Nutrient Market and Combined Nutrients Market for Pence Spring PSD .160

Table 6.43: Cost of Treatment Facility Upgrade to meet TP Limits and Cost of Credits Purchase in Single Nutrient Market and Combined Nutrients Market for Union PSD. 162 
Table 6.44: Cost of Treatment Facility Upgrade to meet TP Limits and Cost of Credits Purchase in Single Nutrient Market and Combined Nutrients Market for Town of Alderson .163 Table 6.45: Cost of Treatment Facility Upgrade to meet TP Limits and Cost of Credits Purchase in Single Nutrient Market and Combined Nutrients Market for City of Ronceverte 164 Table 6.46: Cost of Treatment Facility Upgrade to meet TP Limits and Cost of Credits Purchase in Single Nutrient Market and Combined Nutrients Market for City of White Sulfur Spring . 166

Table 6.47: Cost of Treatment Facility Upgrade to meet TP Limits and Cost of Credits Purchase in Single Nutrient Market and Combined Nutrients Market for Town of Hillsboro.167 Table 6.48: Cost of Treatment Facility Upgrade to meet TP Limits and Cost of Credits Purchase in Single Nutrient Market and Combined Nutrients Market for City of Marlinton ... 168 Table 6.49: Compliance Costs for WWTP Upgrades and Cost in a Single Market of Compliance

TP. 169

Table 6.50: Compliance Costs for WWTP Upgrades and Cost in a Combined Market of

Compliance TP and TN.

Table 6.52: Number and Percentage of Farmers with BMPs in Crop and Pasture/Grass Lands 172 Table 6.53: Current Level of Selected BMPs in Crop and Pasture/Grass Lands 172

Table 6.54: Supply of Nutrient Credits under Different Baseline Requirements .173

Table 6.55: Average Cost of Credit Generation under Different Baseline Requirements for the

Crop Land Owners 175

Table 6.56: Average Cost of Credit Generation under Different Baseline Requirements for the Pasture/Grassland Owners 176

Table 6.57: Percentage of Farmers Who Could Not Participate in a WQT Market 178 


\section{LIST OF FIGURES}

Figure 1.1: State Shares of the Total Nitrogen and Phosphorus to the Gulf of Mexico ................5

Figure 1.2: Stream Impairment in the Greenbrier River Basin ..........................................

Figure 2.1: Leading sources of River and Stream impairment in the United States..................17

Figure 3.1: Equilibrium Market Price and Quantity in a Perfect Competitive WQT Market .......61

Figure 3.2: Demand for and Supply of TP Credits in a TP Nutrients Market under a Combined Market where WWTP can purchase TN Credits

Figure 3.3: Demand for and Supply of N Credits when a WWTP Considers N Credits Purchase

Figure 4.1: Locality Map of Greenbrier River Watershed .............................................68

Figure 4.2: Land Use and Land Cover in the Greenbrier River Basin..................................69

Figure 4.3: Rivers and Streams in the Greenbrier River Watershed ......................................70

Figure 4.4: Location of WWTPs in the Greenbrier River Basin ..................................... 71

Figure 5.1: Sub-Watersheds of Greenbrier River Watershed ............................................76

Figure 5.2: Land Use and Land Cover in the Greenbrier River Watershed ..............................77

Figure 5.3: Streams Network in the Greenbrier River Watershed ......................................78

Figure 5.4: Location of the Significant Point Sources in the Greenbrier River Watershed ..........79

Figure 5.5: Monthly Monitored and Estimated Stream Flow in Alderson, Greenbrier River (Non-

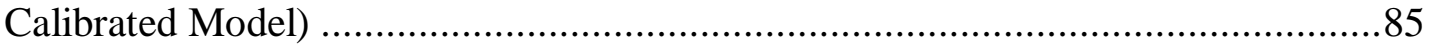

Figure 5.6: Monthly Monitored and Estimated Stream Flow in Alderson, Greenbrier River

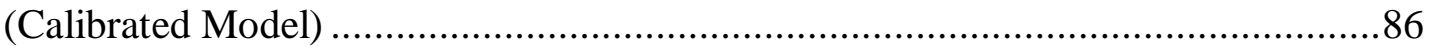

Figure 5.7: Monthly Monitored and Estimated TN (mg/l) In Greenbrier River at Alderson.......87 
Figure 5.8: Monthly Monitored and Estimated TP (mg/l) in Greenbrier River at Alderson ........88

Figure 5.9: Location of the Survey Respondents in the Greenbrier River Watershed............... 107

Figure 6.1: Sub-Watershed Level Average Annual Nitrogen Loadings .............................. 117

Figure 6.2: Sub-Watershed Level Average Annual Phosphorus Loadings ............................ 118

Figure 6.3: Sub-Watershed Level Nitrogen Loadings under Existing BMP Condition .............119

Figure 6.4: Sub-Watershed Level Phosphorus Loadings under Existing BMP condition ..........119

Figure 6.5: Sub-Watershed Level Nitrogen Concentration $(\mathrm{mg} / \mathrm{l})$ in the Streamflow ............... 120

Figure 6.6: Sub-Watershed Level Phosphorus Concentration (mg/l) in the Stream flow ..........121

Figure 6.7: Sub-watershed Level Nitrogen Loadings from Crop and Pasture/Grasslands ......... 122

Figure 6.8: Sub-watershed Level Phosphorus Loadings from Crop and Pasture/Grasslands ..... 122

Figure 6.9: Estimated TN and TP Reduction from the Existing BMPs in the Agricultural Lands

Figure 6.10: Potential TP Credit Demand by WWTPs at Different TP limits in the Greenbrier

River Watershed

Figure 6.11: Potential TN Credit Demand by WWTPs at Different TN limits in the Greenbrier

River Watershed.

Figure 6.12: Potential Supply of TN Credits from the Implementation of BMPs on the

Agricultural Lands.

Figure 6.13: Potential Supply of TP Credits from the Implementation of BMPs on agricultural

Land. 136

Figure 6.14: Supply of TN under Existing BMPs and 100\% NMP Baseline Requirements ......174

Figure 6.15: Supply of TP under Existing BMPs and 100\% NMP Baseline Requirements .......174 


\section{LIST OF ABBREVIATIONS}

BMP: $\quad$ Best Management Practice

CRP: Conservation Reserve Program

CSP: $\quad$ Conservation Security Program

CWA: Clean Water Act

CWNS: $\quad$ Clean Watershed Needs Survey

EQIP: $\quad$ Environmental Quality Incentives Program

GIS: Geographical Information System

GRW: $\quad$ Greenbrier River Watershed

GWLF: Generalized Watershed Loading Function

HSPF: $\quad$ Hydrologic Simulation Program

LA: Load Allocation

MAC: $\quad$ Marginal Abatement Cost

MRB: $\quad$ Mississippi River Basin

NPDES: $\quad$ National Pollutant Discharge Elimination System

NPS: $\quad$ Nonpoint Source

NRCS: $\quad$ Natural Resources Conservation Services

OECD: Organization for Economic Co-operation and Development

PRedICT: Pollution Reduction Impact Comparison Tool

PS: $\quad$ Point Source

SPARROW: SPAtially Referenced Regressions On Watershed attributes

SWAT: $\quad$ Soil and Water Assessment Tool

TC: $\quad$ Total Cost 
TMDL: $\quad$ Total Maximum Daily Load

TN: $\quad$ Total Nitrogen

TP: $\quad$ Total Phosphorus

TSS: $\quad$ Total Suspended Solids

USEPA: United States Environmental Protection Agency

USGAO: United States Government Accountability Office

WASP: $\quad$ Water Quality Simulation Program

WCMS: Watershed Characterization and Modeling Software

WLA: $\quad$ Waste Load Allocation

WQM: $\quad$ Water Quality Model

WQT: $\quad$ Water Quality Trading

WTA: Willingness-to-Accept

WTP: Willingness-to-Pay

WVDEP: West Virginia Department of Environmental Protection

WWTP: $\quad$ Waste Water Treatment Plant 


\section{CHAPTER 1: INTRODUCTION}

\subsection{INTRODUCTION}

Water resources impairment is a continuing concern to healthy aquatic ecosystems in the United States. Despite design and implementation of many policies to reduce the pollution level in water bodies, water quality improvement outcomes have not been completely satisfactory. Since the passage of Clean Water Act (CWA) in 1972, the federal government has provided more than $\$ 85$ billion funding to cities and states for the construction of wastewater treatment facilities to reduce pollutants discharge from industrial and municipal sources throughout the U.S. (Copeland 2011). The CWA emphasizes the federal-state partnership in which the federal government sets the standards for pollution abatements and states carry out implementation and enforcement activities (Copeland 2010). However, many U.S. water bodies are unmonitored. For example, the most recent national water quality inventory indicates that $44 \%$ of rivers and streams, $64 \%$ of lakes, ponds and reservoirs, and $30 \%$ of bay and estuaries remain impaired (USEPA 2009). While the CWA has played a role in curbing pollutants discharge from the point sources, lack of funding for facility upgrades in many places is a current major issue for point source pollution control. Annually, a large amount of wastewater is discharged into the water bodies from point sources without sufficient treatment (USEPA 2008).

Nonpoint source pollution, including agricultural runoff of nutrients and sediments, is the main cause of surface water impairment in the U.S. (USEPA 2009). The control of this pollution is one of the most difficult policy challenges in the U.S. Excess nutrient loading from nonpoint sources is the primary cause of excessive growth of algae in many river and coastal aquatic ecosystems (Osterman et al. 2006). The most critical deficiency of the CWA is that this 
legislation does not regulate agriculture nonpoint sources (James 2003, Faeth 2000). The CWA leaves regulation of nonpoint source pollution to state governments. Nonpoint source pollution is addressed primarily through non-regulatory means, such as incentive and cost-share mechanisms, and voluntary best management practices. These programs have not been successful in making significant progress in controlling pollutant runoff from the agricultural lands (Williams 2002).

The cost of improving impaired waters in the U.S. is very high. Among the 30,000 wastewater treatment and collection facilities in U.S., most of them need to be upgraded to meet new water quality regulatory requirements (USGAO 2008). The U.S. Government Accountability Office (GAO) estimated that investments for upgrading aging and deteriorating water infrastructures lie in the range of $\$ 485$ billion to $\$ 1.2$ trillion over the next 20 years (USGAO 2008). The Clean Watersheds Needs Survey Report also projected infrastructure related investments for publicly owned wastewater systems of $\$ 202.5$ billion through 2024 (USEPA 2008). USGAO also reported that about one-third of the utilities had deferred maintenance due to insufficient funds (USGAO 2002).

Nonpoint source pollution control also requires significant funding. U.S. Environmental Protection Agency (USEPA) (2008) reported that prevention of current water pollutions from nonpoint sources needs $\$ 38.3$ billion amount of funds (USEPA 2008). For nonpoint source pollution control, the U.S. Department of Agriculture (USDA) and most states have long offered farmers incentive payments for the adoption of conservation practices. For example, between 1997 and 2008, the total amount of funds expended on the Environmental Quality Incentive Program (EQIP) was $\$ 753$ million, and on the Conservation Reserve Program (CRP) was $\$ 1.73$ billion (NRCS 2009). This total fund was allocated to the states by NRCS according to the 
proportion of crop land, pasture/grass land, livestock, impaired rivers and streams, and including other factors in the state (Stubbs 2010). The state level funding for EQIP and CRP in 2011 show that the state of Texas and California have received highest amount of funding for EQIP and the state of Iowa and Illinois have received highest amount of funding for CRP (NRCS 2012, EWG 2012). The state of West Virginia ranks $43^{\text {th }}$ and $38^{\text {th }}$ position based on the total amount of EQIP and CRP funding received in 2011, respectively.

Innovative policy solutions are required to overcome this large monetary burden and reduce the pollution discharges from both point and nonpoint sources. The USEPA has advocated least cost strategies for the water quality protection, improvement, and management of river, streams, and coastal waters. One such innovative policy solution recommended by many recent environmental economists is water quality trading (WQT). WQT is based on the concept that pollution dischargers (point and non-point sources) in a watershed face different abatement costs structures. Sources with low abatement costs can abate excess amount of pollution and then sell their excess abatement credits to high-cost abatement sources. The overall costs of pollution reduction in a watershed can be minimized from the trading of credits among the sources in a WQT market (Caplan 2012, Horan and Shortle 2011, King 2005). The USEPA estimates that under the WQT system overall cost saving could be over $\$ 900$ million dollars annually (USEPA 2003).

The potential of agricultural nonpoint source pollution control is widely recognized. Best Management Practices (BMPs) implemented on agricultural lands are considered as effective and economical for reducing agricultural pollution (Cheubey et al. 2010, Cestti et al. 2003). These practices effectively use agricultural chemicals and decrease surface runoff from the agricultural lands. There are several BMPs, for example, conservation tillage, cover crop, 
nutrient management plan, buffer strip etc. currently under implementation on agricultural lands. The costs of pollution reduction from the implementation of BMPs on the agricultural lands are significantly lower than the point source abatement costs (CTIC 2011, Ribaudo and Nickerson 2009).

The USEPA has emphasized a watershed-based approach to address various water quality problems. This approach defines the roles, priorities, and responsibilities of all stakeholders to manage the existing water resources within a watershed. The USEPA recognized that the watershed-based approach would minimize the overall costs of water quality management and can protect and restore water resources more effectively compared to large scale ecosystem restoration (USEPA 2008). Water quality trading is one such program that can help to achieve water quality goals more efficiently within the watershed-based approach.

\subsection{WATER QUALITY ISSUES IN THE GULF OF MEXICO}

Excessive nutrients loading from the Mississippi River basin into the Gulf of Mexico is one of the serious water pollution issues in the U.S. The excessive nutrients loading from both point and nonpoint sources are causing algal blooms and development of hypoxic (oxygen-deficient) water in the Gulf of Mexico (USEPA 2007). In particular, excess nutrients in the water body accelerate eutrophication which is natural aging of water bodies brought on by nutrient enrichment (Rabalais et al. 2002). WV is one of the states within the Mississippi River basin which also contributes nutrients and sediments to the Gulf of Mexico.

Excessive use of chemical fertilizers and improper management of livestock manures in the River basin is causing large amount of nitrogen $(\mathrm{N})$ and phosphorus $(\mathrm{P})$ runoff from agricultural lands (Rabalais et. al. 1996, Goolsby et al. 1999). Recent interest in biofuel production is also encouraging producers to extend and intensify crop production with large amount of chemical 
fertilizers application in the river basin (NRC 2008). Alexander et al. (2008) estimate that agricultural sources contribute about $70 \%$ of the total nitrogen and phosphorus load from the Mississippi River basin into the Gulf of Mexico. Only about 10\% of nitrogen and phosphorus are contributed from the point sources. Figure 1.1 presents the state share of the total nitrogen and phosphorus to the Gulf of Mexico. WV falls under third category which contributes 1-5\% of total nitrogen and phosphorus delivered from the basin to the Gulf of Mexico (Alexander et al. 2008). Alexander et al. estimate that WV contributes $1.8 \%$ of total nitrogen and $2.1 \%$ of total phosphorus flux delivered to the Gulf of Mexico.

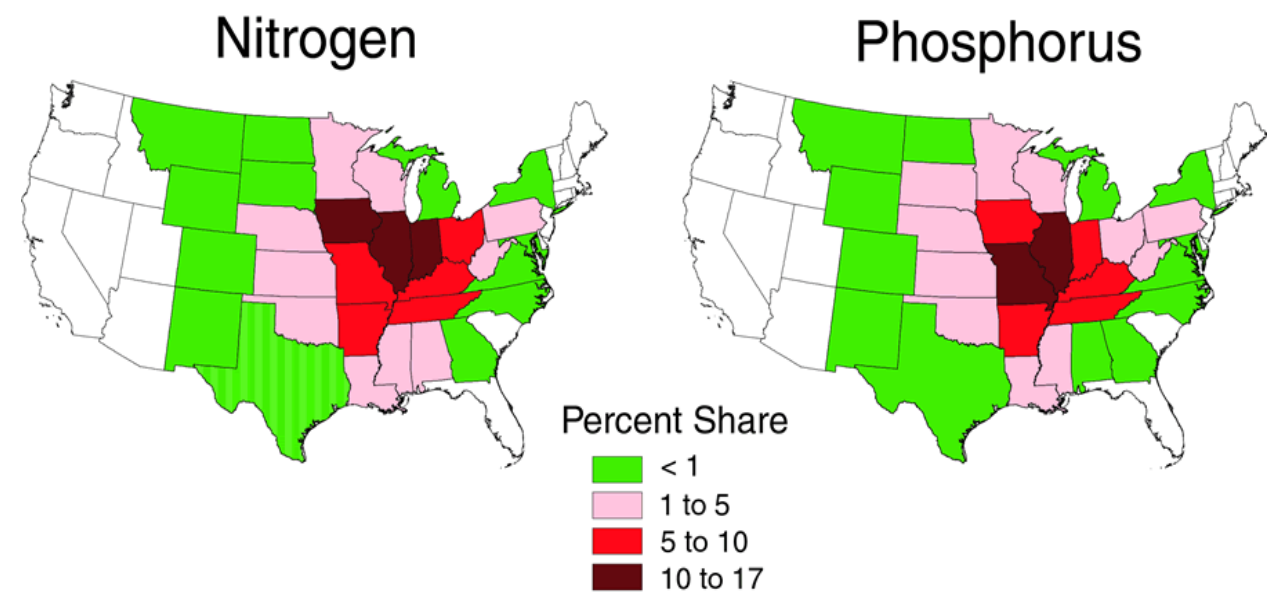

Figure 1.1: State Shares of the Total Nitrogen and Phosphorus to the Gulf of Mexico After the CWA passed in 1972, the Mississippi River basin has received a significant attention of many watershed based water quality management programs as a result of the declining water quality in the river/streams, lakes, and growing hypoxic water zone in the Gulf of Mexico. After the enactment of Harmful Algal Bloom and Hypoxia Research and Control Act of 1998, a task force has been established to conduct a scientific assessment of the causes and consequences of hypoxia in the Gulf of Mexico and develop a plan of action to reduce, mitigate, and control hypoxia problem (CENR 2000). USEPA's Science Advisory Board recommends at least a $45 \%$ total nitrogen and phosphorus discharge reduction in order to decrease the size of the 
hypoxic zone and improve water quality in the Mississippi river and its tributaries (USEPA 2007). The latest estimates of the Mississippi River/Gulf of Mexico Watershed Nutrient Task Force show that a $12 \%$ decline in total nitrogen flux and a $17.5 \%$ increase in total phosphorus flux compared to the averages from the 1980-1996 (USEPA 2011). These estimates indicate that reducing of nutrients discharges into the river and streams from the various sources remains a great challenge to improve the water quality in the Mississippi River Basin.

Many research studies within the Mississippi River basin have focused mainly on the causes of hypoxia in the Gulf of Mexico and possibilities in reducing nutrients discharges into the rivers and streams (Rabalais et al. 2002, Scavia et al. 2003). Some recommendations for nutrients reduction from the agricultural lands include control in fertilizer application in the crop lands, wetland restoration, riparian buffers, and implementation of agricultural BMPs (Doering et al. 1999, Kovacic et al., 2006). Some studies have indicated a possibility of implementing water quality trading programs to reduce the nitrogen and phosphorus discharges from the agricultural lands (Doering et al. 1999, WSTB 2009). The Gulf Hypoxia Action Plan also supports development of WQT programs within the Mississippi River Basin for reducing Mississippi River nutrient inflow to the Gulf of Mexico (Mississippi River/Gulf of Mexico Watershed Nutrient Task Force 2008). The plan recognizes that achieving reduction goals will be expensive and difficult and therefore recommends the market-based programs which combine both voluntary and regulatory programs.

A major proportion of drainage from WV rivers and streams enters to the Ohio River and ultimately to the Gulf of Mexico. Estimates show that WV contributes relatively less nitrogen and phosphorus to the Mississippi River and the development of hypoxia in the Gulf of Mexico (Alexander et al. 2008). Still, nutrient discharged from WV contributes to interstate problems 
and development of hypoxia in the Gulf of Mexico. Any nutrients reduction activities in small and large sub-watershed of Mississippi River basin can contribute to the reduction of hypoxia in the Gulf of Mexico. Thus, it is anticipated that all jurisdictions within the Mississippi River basin will be required to reduce nutrient loads to help reduce Gulf hypoxia.

\subsection{WATER QUALITY PROBLEMS IN WEST VIRGINIA AND GREENBRIER RIVER}

West Virginia is a water rich state. Rivers originating in the state provide a wide range of ecological and economic benefits for its residents. Pollution of rivers, streams, and lakes in WV by point and non-point sources is of great concern (Bhumbla 2010). High levels of pollution in these water bodies can have negative impacts on water quality with associated declines in ecological and economic benefits.

Assessment of nutrient related water quality impairments in WV is very limited. The periodic assessment of streams and rivers in WV indicates that a large proportion of streams and rivers are either impaired or threatened conditions from the nutrient and non-nutrient related pollutants. The most recent water quality assessment report reveals that only $23 \%$ of West Virginia's river and stream miles are either fully supporting all or some assessed uses (i.e. water uses identified in state water quality standards that must be achieved and maintained as required under the Clean Water Act) and one-third of streams are impaired (WVDEP 2010). Streams with insufficient data include $40 \%$ of stream miles. This assessment report explains that the largest percentage of insufficient data is typically for small unnamed tributaries which usually contribute to the larger water bodies. In addition, only $5 \%$ of the lake acreage is fully supporting all uses and $24 \%$ of the lake acreage is fully supporting for some designated uses, whereas $71 \%$ of lakes are impaired for one or more uses (WVDEP 2010). The proportion of streams and rivers that is either fully supporting all or some assessed uses has decreased in the three water quality 
assessment reports. In 2006, the proportion of streams and rivers that is either fully supporting all or some assessed uses was $30 \%$ (WVDEP 2006). This proportion was decreased to $27 \%$ in 2008 and $23 \%$ in 2010 (WVDEP 2010, WVDEP 2008).

The most common impairments of WV waters are: biological impairment, bacterial contamination, pollutants associated with mine drainage (low $\mathrm{pH}$, high concentration of iron, aluminum, and/or manganese), PCB fish tissue contamination, and concentration of mercury, dioxin, selenium, and other elements (WVDEP 2010). Bio-impairment and bacterial contamination in the water bodies are two leading causes of water pollution. In most cases the cause of impairments is listed as unknown but many are suspected to be related to excess nutrients and/or sediment (WVDEP 2010). Run off from the agricultural lands into the water bodies is one of the main causes of bio-impairment and bacterial growth.

Excess growth of algae due to nutrient enrichment is one of the major problems in some of the streams and rivers in WV. This problem is high in the Greenbrier River, Tygart Valley River, Bluestone River, and Cacapon River; moderate in south branch of Potomac River and New River; and low in Hughes River (Summers 2008, WVDEP 2010). The algal growth in many segments of the Greenbrier River is in severe condition. West Virginia Department of Environmental Protection (WVDEP) undertook a detailed study of the problem in response to numerous complaints regarding the growth of algae in the Greenbrier River. According to the study the Greenbrier River had the most severe algae problems of all West Virginia Rivers (Summers 2008).

The WVDEP integrated water quality monitoring and assessment report listed about 103 miles of Greenbrier River as impaired from algal blooms (WVDEP 2010). The primary source of the problem has been identified as high phosphorus concentrations discharged from municipal 
wastewater treatment plants combined with nitrogen discharges from agricultural sources and septic systems in the watershed (WVDEP 2011). The Greenbrier River is more sensitive to phosphorus concentration for algal blooms compared to other rivers and streams in WV. Total phosphorus above $0.01 \mathrm{mg} / \mathrm{l}$ is sufficient for excessive growth of algae in the River (Summers 2008). The excessive levels of phosphorus and algal growth impair the designated recreational and drinking water beneficial uses of the river causing undesirable taste and bad odor. Figure 1.2 presents stream impairments from biological source, fecal and algae, and fecal coliform in the Greenbrier River Basin (WVDEP 2011). The main section of the Greenbrier River is impaired from the growth of fecal and algae.

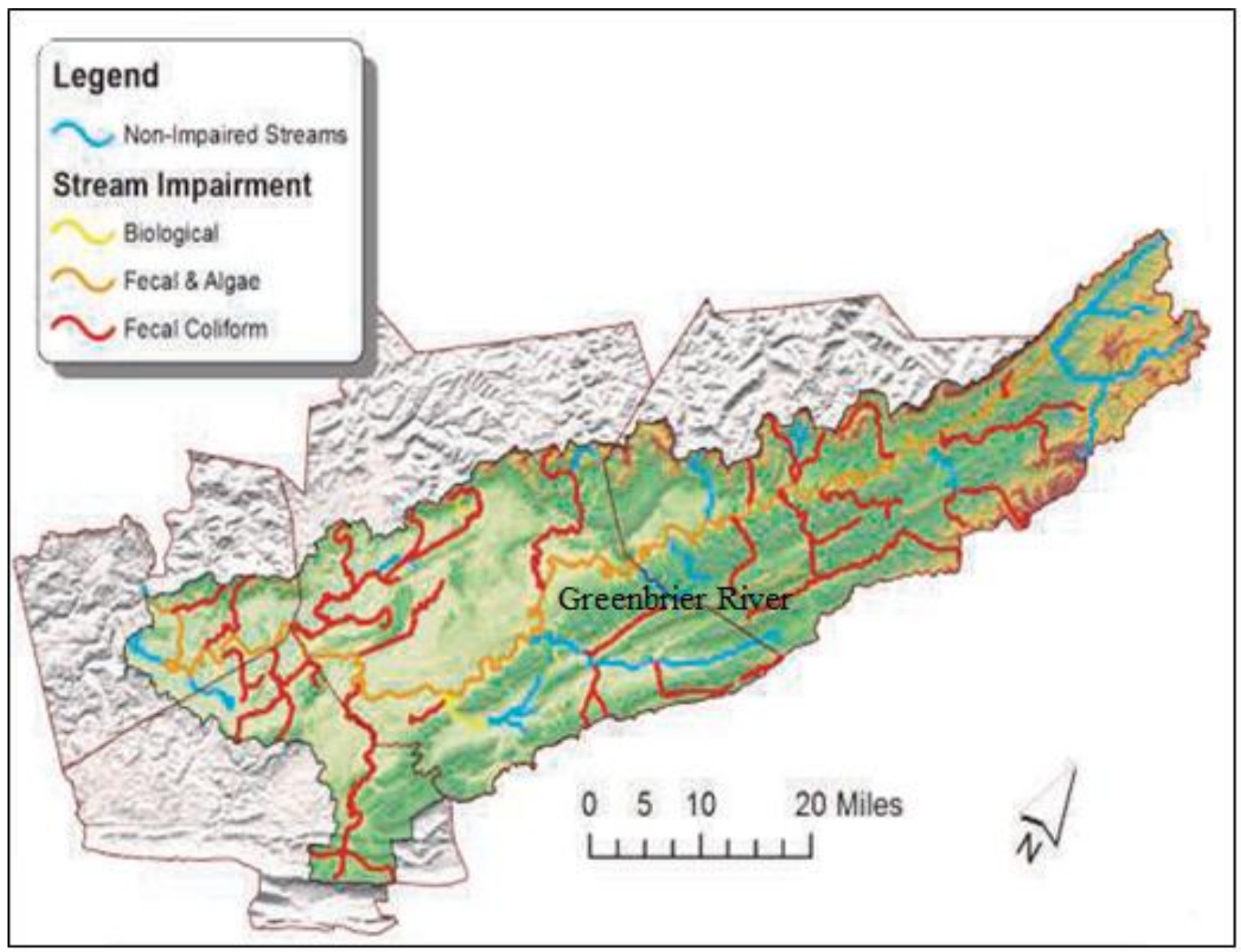

Figure 1.2: Stream Impairment in the Greenbrier River Basin 
Algal blooms in the Greenbrier River create a need for nutrients discharge reduction programs from wastewater treatment plants (WWTP) and agricultural sources in the Greenbrier River watershed. The WVDEP proposed a standard of $0.01 \mathrm{mg} / \mathrm{l}$ for total phosphorus on the Greenbrier River. However, this standard was not approved by the 2011 WV legislature. Recently, WVDEP proposed relatively less stringent total phosphorus standards $(0.5 \mathrm{mg} / \mathrm{l})$ to the wastewater water treatment plants along the River. To meet this new total phosphorus limitation, existing dischargers need to make significant upgrades in their WWTPs and they require large amount of capital investments. Both the WWTPs and the WV legislature recognized that compliance with the proposed standard was too expensive.

A broad watershed-based approach, which can combine both voluntary and regulatory methods, is essential to reduce the serious water quality problems in the Greenbrier River and its tributaries. Research is needed to determine suitable BMPs for reducing nutrients runoff from the crop and pasture lands in the Greenbrier River watershed. This research examines suitability of some agricultural BMPs as potential method of nutrients reduction from the agricultural lands. The research also looks at the possibility of nutrients trading between WWTPs and farmers to minimize the costs of WWTPs upgrade.

As the WVDEP moves towards assigning a total phosphorus discharge limitation of $0.5 \mathrm{mg} / \mathrm{l}$ to the all WWTPs in the Greenbrier River, phosphorus trading between WWTPs and agricultural sources could present a very attractive alternative to treatment plant upgrades. This alternative allows WWTPs to pay for upstream improvements to lands that drain into an impaired water body. In particular, farmers in the upstream can implement agricultural best management practices on their lands and reduce phosphorus discharge at a lower cost than WWTPs with treatment plant upgrades. 


\subsection{OBJECTIVES OF THE STUDY}

The overall goal of this study was to assess the feasibility of a water quality trading program in the Greenbrier River sub-watershed within the Kanawha River watershed. This watershed level study will help Greenbrier River watershed communities, policy makers in WVDEP, and other stakeholders to design and implement a cost effective program to restore and protect river and stream water quality in the watershed. This assessment required information about both quantitative and qualitative aspects of water resources including the information of all pollution dischargers within a watershed. The targeted pollutant for this research was total phosphorus (TP) discharged from wastewater treatment plants and agricultural sources. The research also includes total nitrogen (TN) to compare the single nutrient WQT market (TP) and combined nutrient WQT markets (TP and TN) in the watershed.

A nutrient trading program would be successful when there is sufficient nutrient credit supply to meet the demand for pollutant reduction credits and have potential for improving the overall cost-effectiveness in pollution control (Kieser and Associates 2004, King and Kuch 2003). Thus, the first objective of this dissertation is to quantify the load reduction potentials for total phosphorus (TP) and total nitrogen (TN) from the agricultural lands in the watershed. The potential of TP and TN reduction may differ according to the soil type, topography, hydrology, and land management practices in the different locations. It requires an estimation of the current loadings of TP and TN and future loadings of TP and TN after the implementation of agricultural BMPs in the watershed.

This study uses the GIS based MapShed water quality model to estimate current pollution loadings and potential of future pollutant load reduction from the implementation of BMPs in each sub-watershed of the Greenbrier River watershed. Total potential nitrogen and phosphorus 
credits supply are estimated based on the potential load reductions from the implementation of BMPs in the agricultural lands considering different baseline requirements and trading ratios. The costs of TP and TN reductions from the implementation of BMPs were also estimated to determine the cost of nutrient credits (willingness-to-accept) in each sub-watershed.

The second objective for this dissertation is to estimate the demand for nutrient credits (TP and TN) in the watershed. The demand for nutrient credits depends on the effluent limits set by regulatory authority and costs of treatment plant upgrade for the point source (i.e. WWTPs) to meet a specified effluent limit in the watershed. This study estimates TP and TN load reduction requirements and the costs of such reductions for all the seven major WWTP in the Greenbrier River watershed under different effluent limits. The aggregate $\mathrm{TP}$ and $\mathrm{TN}$ reduction requirements for these WWTPs represent total demand for TP and TN in the watershed. Similarly, the average costs of TP and TN reduction for each WWTP denote its maximum level of willingness-to-pay (WTP) to purchase nutrient credits from agricultural non-point sources.

Following the TP and TN credits supply and demand estimations, this study analyzes the cost effectiveness of nutrient trading in the Greenbrier River watershed. Thus, third objective of this dissertation is to estimate the total net economic benefits from the WQT program and cost savings and load reductions potentially achievable through point/non-point sources trading. This study compares the cost of point source treatment upgrades to achieve load reduction to the cost of comparable load reduction by agricultural sources, estimates the total cost saving, and total economic benefit from the trading. This comparison between demand for and supply of nutrient credits reveals the potential for a nutrient credit market in the watershed level.

The optimal design of WQT program is also influenced by the baseline requirements for agricultural sources (Ghosh et al. 2011), trading ratio (Hung and Shaw 2005), environmental 
target (Nguyen et al. 2010), and number of point and nonpoint pollution dischargers in a watershed (Morgan and Wolverton 2005). A WQT feasibility study requires considering such parameters that can determine the success or failure of a WQT program in a particular watershed. Thus, the fourth objective of this dissertation is to analyze the impacts of market design parameters on the performance of water quality trading markets. Four market design parameters: effluent limitations for WWTPs, trading ratio between point and non-point sources, baseline requirements for agricultural sources, and market type were considered. This analysis examines cost saving and potential economic benefits from the WQT program under different scenarios in the Greenbrier River watershed.

Farmers in the watershed can have already implemented BMPs on their agricultural lands voluntarily and/or with support from the different cost share programs, for example, the Environmental Quality Incentives Program (EQIP), Conservation Reserve Program (CRP), and Conservation Security Program (CSP). This ex-post implementation of BMPs in the agricultural lands can have significant impacts on the total amount of credit generation, per unit cost of credits, and participation by agricultural sources to the WQT program in the watershed. Information about the existing level of agricultural BMPs in the watershed can help in designing baseline requirements for the agricultural sources. Thus, the fifth objective of this dissertation is to assess the impact of ex-post implementation of BMPs in the agricultural land in the potential WQT market. Information collected from the BMPs survey in the watershed is used to analyze the impact of current level of BMPs in the WQT market. 


\section{CHAPTER 2: LITERATURE REVIEW}

\subsection{WATER QUALITY REGULATIONS}

The main legislation governing water pollution within the U.S. is the Clean Water Act (CWA) originally enacted in 1948 (Copeland 2010). The revised Clean Water Act of 1972 aims to restore and maintain the chemical, physical, and biological properties of surface water in all watersheds. This Act had goals to attain fishable and swimmable waters by 1983 and eliminate pollutants discharge into waters by 1985 . The CWA made the USEPA responsible for setting national standards for the discharge of effluents on an industry-by- industry basis considering both the capabilities and the costs of implementation (Adler et al. 1993).

The approach to setting standards included: (1) establishing a nationwide, base-level treatment through an assessment of what is technologically and economically achievable for a particular industry, and (2) requiring more stringent levels of treatment for specific plants if necessary to achieve water quality objectives for a particular body of water into which that plant discharges. This approach established the National Pollutant Discharge Elimination Program (NPDES) permit system to control pollution form point sources, which is administered by the USEPA and state governments awarded primacy. The permit requires point source dischargers to comply with technology-based controls or water quality-based controls to meet the state's water quality standards (USEPA 1994). This Act was amended in 1977 and 1987 to expand the EPA's roles to address nonpoint source pollution through voluntary programs. Besides the NPDES programs, the National Pretreatment Program was designed to reduce the amount of pollutants discharge into municipal sewer systems by industry and other non-domestics wastewater sources (Pharino 2007). 
The CWA requires states to identify those waters which cannot meet the water quality standards and develop Total Maximum Daily Loads (TMDLs). TMDLs are used to calculate and specify the maximum amount of pollutants that a water body can receive and maintain water quality standards (USEPA, 1996). TMDLs are focused primarily on developing better estimates of the contribution of nonpoint sources to total pollution loads in rivers/streams in a watershed (Keplinger 2003). Regulators can use TMDLs outcomes to establish waste load allocation (WLA) for point sources, load allocations (LA) for nonpoint sources and natural sources, and margin of safety to ensure achievement of water quality goals (USEPA 1999).

The exemption of nonpoint source pollution from the NPDES program did not result from a failure to appreciate the problem (Gould 1990). However, the number and variety of nonpoint source pollution sources, the site-specific nature of such pollution, the lack of appropriate control technologies, cost-effective pollution monitoring mechanism, and a traditional state role limit the nonpoint source pollution control from the similar rules and regulations implemented for point source pollution control (USEPA 1989). Currently, the nonpoint pollution controls occur mainly through cost-share programs provided by the USDA and USEPA. USDA programs include the Conservation Reserve Program (CRP), the Environmental Quality Incentive Program (EQIP), and the Conservation Security Program (CSP). These programs aim to balance incentives for crop production with incentive for land and water conservation (Feather and Cooper 1995). Approximately half of the USDA fund goes to the CRP which primarily aims to reduce soil erosion from the agricultural lands by keeping land out of production (Faeth 2000). Adjustments in these programs have attempted to make it more responsive to water quality needs by considering conservation measures on working farmland rather than land retirement (Breetz and Fisher-Vanden 2007). 
Another program, EQIP, was established by the 1996 'Farm Bill' and was considerably expanded and amended by the 2002 'Farm Bill'. Its goals are to promote agricultural production and environmental quality and to optimize environmental benefits per program dollar (USDA/NRCS 2003). All states currently have USEPA-approved nonpoint source water quality management programs. Individual states have a large responsibility to manage nonpoint source of water pollution through voluntary incentive programs that includes best management practices (BMP), education, and technical and financial assistance provided by federal and state government (Shortle and Abler 2001).

\subsection{WATER QUALITY TRENDS AND ISSUES}

Over the last four decades of the Clean Water Act implementation, the approach in the CWA has been greater control of pollution discharges from point sources under the NPDES program than from nonpoint source under voluntary approach. It is generally agreed that the Clean Water Act has achieved some level of success in improving water quality. However, a systematic assessment of the effects of the Clean Water Act on water quality is very difficult and uncertain because of a lack of suitable data and the difficulty in to aggregating trend data across water bodies and pollutants (Harrington 2003). The principle source of information about the US water quality is the EPA's National Water Quality Inventory. This periodic inventory of national water quality provides the information of assessed river/stream, lake, pond and reservoirs, and bays and estuaries waters. The 2004 inventory report identified 55\% of assessed river/stream miles, 53\% of assessed lake, pond and reservoirs, and 68\% assessed bays and estuaries support designated water use (USEPA 2004). Since 1988 the proportion of the waters surveyed that fully support their designated uses has declined, while those waters not supporting or partially supporting has increased. This trend implies that the US is failing to restore the water quality and 
meet the goals of Clear Water Act. Not only is the US failing to meet the goals set out by Clean Water Act, but forward progress seems to be slow and difficult (Faeth 2000).

According to the U.S. National Water Quality Inventory, agricultural nonpoint source is the leading source of impairment to rivers and lakes (USEPA 2009). Figure 2.1 indicates that agricultural sources contribute about $40 \%$ of total pollution in the rivers and streams impairment. Percent do not add up to $100 \%$ because more than one source may impair a waterbody. Pollutants from agricultural croplands and livestock operations include excess fertilizers, herbicides and insecticides, sediments, and manure runoff.

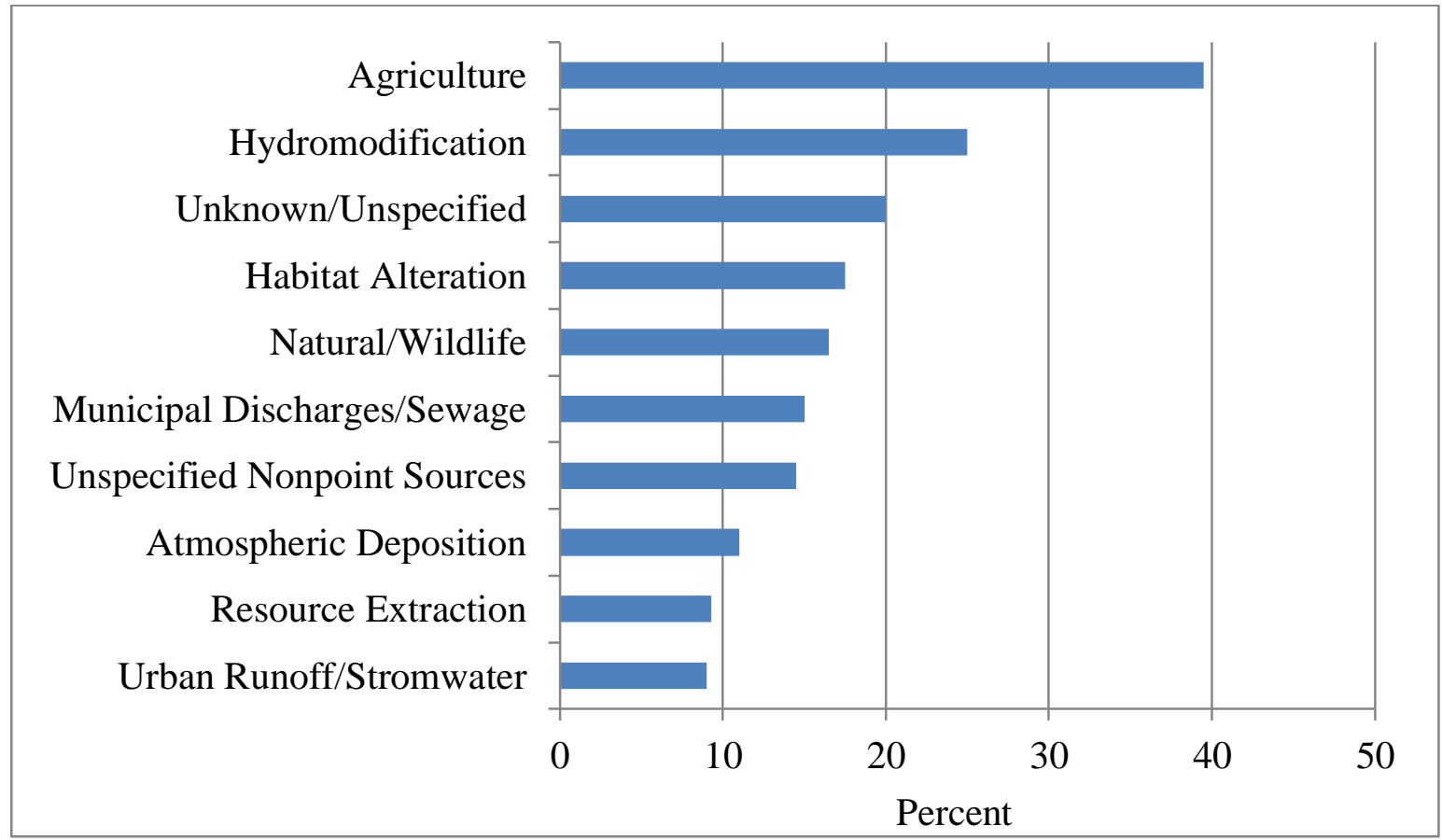

Figure 2.1: Leading sources of River and Stream impairment in the United States

Pollution from agricultural sources enters to the river and streams diffusely in the runoff or leaching from rain or melting snow. The runoff process depends on a number of factors such as the amount of variable production inputs used (e.g. chemical fertilizers, pesticides, irrigation water etc.), management practices (e.g. conservation tillage, crop rotation, pesticide application, etc.), land use, rainfall, soil characteristics, and topography (Horan and Ribaudo 1999). It is very 
difficult and often too costly to observe and measure the diffusion of pollutants from agricultural nonpoint source (Shortle and Abler 1997). Industrial and municipal discharges are leading contributors to impairment in the estuaries.

Nutrient and sediment loadings from agriculture are significant contributors to water quality problems such as hypoxia in the Gulf of Mexico and decreased fish populations in Chesapeake Bay (USEPA 2003). Point source pollution reductions alone are not sufficient to overcome these problems and that the challenges presented by nonpoint sources need to be addressed (Ruppert 2004). The solutions to these water quality problems require innovative approaches that are aligned with water quality regulation programs. To address these problems, water quality regulation policy has begun to shift from direct regulation to a holistic watershedbased approach. Under this approach, water quality trading has been endorsed as a cost effective tool for achieving or preserving water quality and watershed goals (USEPA 1996, 2003). The USDA has recently promoted trading as a means of cooperative conservation with the agricultural sector that can accelerate the restoration and protection of the watersheds (Abdalla $e t$ al. 2007).

\subsection{REQUIREMENTS FOR WATER QUALITY TRADING PROGRAM}

There are several factors that contribute to the design and implementation of a successful water quality trading program in a watershed. The OECD (2001) provides comprehensive information on the overall design and implementation of pollution trading systems for environmental management. This OECD publication broadly discusses the principle issues in designing a tradable permit system including important factors that decision-makers should take into account. The literature also provides theoretical insights into point and nonpoint source nutrient trading systems, discusses practical complexities, and recommends watershed based 
strategies to design and implement a trading program (e.g. Horan and Shortle 2011, Ribaudo and Gottlieb 2011, Ribaudo and Nickerson 2009, Shortle and Horan 2008, Horan and Shortle 2005). King and Kuch (2003) also provide a detail discussion about the basic conditions required for a successful nutrient trading program.

The USEPA provides a watershed-based nutrient trading framework (USEPA 2003). These policy guidelines were first published in 1996 and have been revised in 1999 and 2003. The WQT handbook (USEPA 2004) and WQT toolkit for permit writers (USEPA 2007) further discuss step-by-step processes for determining the feasibility of a watershed-based nutrient trading program. This section discusses different elements of nutrient trading programs including their potential impacts on the establishment of WQT system in a watershed. The discussion is divided into three subsections: setting water quality goals, legal provisions, and technical requirements.

\subsubsection{SETTING WATER QUALITY GOALS}

To begin the discussion on setting water quality goals to establish a water quality trading market, it is useful to discuss Clean Water Act's goals of restoration and maintain water quality in the U.S. This Act aims to "...restore and maintain the chemical, physical, and biological integrity of the Nation's water" (Section 101a) in the all watersheds (CWA 1972). According to this Act, each state is required to set water quality standards for all pollutants in all kinds of surface waters. Such standards must be based on the scientific judgments on pollutant concentrations and its effects on aquatic life and human health (USEPA 2003). All states should follow the CWA and the USEPA guidelines; however, they can modify the standards according to site-specific conditions or adopt other methods that can be scientifically defendable (USEPA 2011). 
The CWA mandated that the USEPA facilitate establishment of limitations for each pollutant that can be discharged by the pollution sources. Initially, the USEPA developed criteria only for toxic chemicals (USEPA 1985), which have limited applicability to nutrients such as TN and TP (Yuan et al. 2010). The National Water Quality Inventory Report of 1988 and subsequent reports indicate that nutrients enrichment in the water body is one of the major causes of water quality impairment. The impacts of these nutrients on water quality are well recognized in the literature (Carpenter et al. 1998, Smith 2003, Hoorman et al. 2008). In response to this problem, USEPA has started to develop nutrient criteria for different types of water bodies since 1998.

Setting water quality goals for a water body includes a specification of designated uses (e.g. boating, fishing, swimming, and drinking), setting criteria to protect those uses, and identification of anti-degradation and water quality improvement strategies in order to protect water quality for designated uses (USEPA 2000a). Each state is required to identify all threatened and impaired waters (303d list) that do not maintain specified water quality standards and need to develop TMDLs.

The USEPA developed the "National Strategy for the Development of Regional Nutrient Criteria" report that provides a framework to assess nutrient status in the surface waters and develop regional-specific numeric nutrient criteria (USEPA 1998). This strategy provided a technical guidance manual to develop nutrient criteria for four types of waters, i.e. rivers and streams (USEPA 2000a), lakes and reservoirs (USEPA 2000b), estuaries and coastal waters (USEPA 2001), and wetlands (USEPA 2008). Each state is required to develop nutrient standards based on EPA guidelines and adopting those standards for their waters. These water quality criteria should be consistent with the CWA's goal of maintaining physical, biological, and chemical properties of all waters and their designated uses. States also are required to 
identify all threatened and impaired waters (303d list) that do not maintain specified water quality standards. Failure to comply the EPA water quality standards may result in development of TMDL for the watershed (Selman et al. 2009).

TMDL is a pollution discharge standard which currently most of states use as an enforcement tool for water quality regulation. During the TMDL process, maximum amounts of pollutants are calculated that a water body can receive and still maintain water quality standards (USEPA 1996). This creates a baseline for pollution discharge for both point and nonpoint sources above which no pollution discharge should be allowed (Faeth 2000). Once a baseline level of water quality standard has been established from TMDLs or other methods (if available); several different approaches can be taken to meet the discharge requirements. This process of setting water quality goals and nutrient discharge criteria are extremely important to initiate a water quality trading program in a particular watershed.

The TMDL is a primary policy driver for most of currently active WQT programs. More than $80 \%$ of currently active WQT programs (17 out of 21 ) are under a TMDL and remaining programs (Bear Creek WQT program, Pennsylvania WQT program, Virginia WQT program, and Red Cedar River nutrient trading pilot program) are under state developed water quality control regulations. In the Bear Creek, Colorado Department of Public Health and Environment issued Watershed Control Regulation which allocates the waste load for total phosphorus among the point and nonpoint sources. Pennsylvania and Virginia WQT program are based on the tributary strategies. These strategies allocated load limits to significant dischargers. The primary regulatory driver for point sources in Red Cedar River nutrient trading pilot program is effluent standards and limitations enforced by the Wisconsin Department of Resources. 


\subsubsection{LEGAL PROVISIONS}

A water quality trading program requires clear legal provisions and enforcement mechanisms in order to run the program successfully. The CWA provides authority for the USEPA and states to develop a variety of programs including WQT to control water pollution. All point sources required to obtain NPDES permits which are administered by USEPA. Point source dischargers must comply with technology-based controls or water quality-based controls to meet the state's water quality standards under this permit system (USEPA 1994). This Act was amended in 1977 and 1987 to expand the EPA's roles to address nonpoint source pollution through voluntary programs. Besides the NPDES programs, the National Pretreatment Program was designed to reduce the amount of pollutants discharge into municipal sewer systems by industry and other non-domestics wastewater sources (Pharino 2007).

The USEPA (2003) recommends that state governments and tribes establish trading program through legislation, rule-making, and incorporating and establishing provision for trading in NPDES permits and TMDLs or other watershed plans. A review of existing WQT programs shows that the NPDES permit system and establishment of TMDLs are two primary regulatory drivers that have been utilized in the almost all WQT programs. The TMDL process is claimed to be the best strategy for addressing impaired waters as it creates pollution trading opportunities in a watershed (USEPA 2004).

There are other important legal issues, such as enforcement and eligibility mechanisms, nutrient credit verification, and liability for noncompliance, for implementing WQT programs (Pharino 2007). It is illegal by law to discharge pollutants beyond the NPDES permit level for all point source NPDES permit holders. Most states have already approved NPDES permit programs which allow them to enforce the law for noncompliance. However, nonpoint source's 
participation in any kind of pollution control programs is voluntary and there is no legal mechanism to enforce noncompliance. This is one of the major obstacles to implementation of point-nonpoint source WQT program. However, many currently active WQT programs overcome this obstacle through different mechanisms.

Nonpoint source's eligibility

The USEPA defines a baseline requirement as a pollutant control requirement that applies to a nutrient credit seller in the absence of trading (USEPA 2007). All agricultural nonpoint sources require that a certain level of pollution reduction must be achieved before a BMP generates pollutant reduction credits. A nonpoint source generating reductions greater than the predefined level of current discharge can sell to the WQT markets (Ribaudo 2009). The regulatory agency can disqualify farmers who have not maintained those requirements. This baseline requirement has major impacts on the cost of pollution reduction from the agricultural sources and overall gains achievable from trading in a watershed (Ghosh et al. 2011).

Different types of baseline requirements for the agricultural sources are discussed in the water quality literature (Ghosh et al. 2011, Ribaudo et al. 2009, CTIC 2006). Some water quality trading programs, for example, Chesapeake Bay Nutrient Trading Program (VA, MD, PA, and Washington, D.C.) and Kalamazoo River water quality trading demonstration project in Michigan, assign a certain percent of pollution reduction from the current discharge for the agricultural sources before BMPs can be used to generate pollutant reduction credits (Breetz et al. 2004). In this type of baseline requirement, all farmers generating any pollutant reductions greater than assigned percent of the current discharge can participate in trading market by selling the excess reductions. This baseline requires the development of TMDL for particular pollutant to allocate loadings for point and nonpoint sources in a watershed. 
A second type of baseline requirement considers existing level of BMPs at a specific date as the baseline. This is the simplest approach to assign a baseline for agricultural sources in the absence of any regulation in place (Ghosh et al. 2011). All farmers can generate pollution reduction credits from BMPs implemented after that date. A third baseline scenario requires all nonpoint sources to adopt some minimum level of BMP or set of BMPs. For example, WQT guidelines in WV state that all farmers must implement nutrient management practices in their agricultural lands before credits can be generated (WVDEP 2009). Only after implementing a nutrient management plan, agricultural sources can generate pollution reduction credits by implementing additional BMPs.

Point source's eligibility

USEPA's WQT guidelines state that all point sources must address the anti-degradation and anti-backsliding conditions under WQT program (USEPA 2003). Point sources sometimes may be end up discharging larger amounts of nutrient under WQT program than before by purchasing nutrient credits from other sources elsewhere in the watershed. This situation has the potential to create hot spot problems in certain areas of the watershed. Therefore, upstream-only or both upstream and downstream trading eligibility must be defined in order to avoid a hot spot problem. The anti-backsliding condition prohibits changes in discharge limitations from more stringent to less stringent in NPDES permits. Such changes can violate the effluent guidelines and water quality standards. Point sources can purchase credits only for over-compliance with the already assigned discharge permits.

\section{Compliance and enforcement}

All WQT programs require creating a strong mechanism for determining and ensuring compliance between trading partners (USEPA 2003). The success of a WQT program depends 
on how well compliance rules are enforced. Enforcement of compliance rules depends on the detection of violations and the legal ability to deal with such violations (Tietenberg 2006). It is very important and difficult task to ensure that a credit-generating practice on agricultural land was properly implemented and it is being properly maintained (Mariola 2009). This requires developing a proper record keeping and reporting system, and monitoring mechanisms.

In many existing WQT programs, either federal agencies (Natural Resource Conservation Service (NRCS)), state agencies (Department of Environmental Protection (DEP) or Water Quality Control Division (WQCD)), or local watershed level authorities are responsible for ensuring compliance, enforcement, and credit verification. All participants of the trading programs are subject to legal action in violation of the compliance. Existing WQT programs use four mechanisms for ensuring compliance: discharge monitoring, stream monitoring, physical inspection, and private contracts.

All currently active WQT programs implement the discharge monitoring system for continuous monitoring of the effluent stream. Trades involving point sources can use the monitoring results of NPDES permits to assist with the verification of compliance. Many programs adopted other mechanisms for ensuring compliance including discharge monitoring system. Stream monitoring (e.g. Chatfield Lake, Great Miami River) involves sampling the water ways to determine nutrient, sediment or temperature levels. Physical inspection (e.g. Cherry Creek, Great Miami River, Lake Dillon, Lower Boise River, Rahr Malting, Beet Sugar, Red Cedar, and Tar-Pamlico) involves site visits to verify the condition of a facility. Some trading programs (Rahr malting, Beet Sugar, Lower Boise River, and Great Miami River WQT programs) use an outside contractor to monitor the responsibilities of the parties in the trade. 


\subsubsection{TECHNICAL REQUIREMENTS}

\section{Unit of nutrient credit}

One of the basic requirements in a WQT market is buyers and sellers agreement upon common unit of nutrient credit measurement. Trading of nutrient credits can occur only when a unit of the credit measurement among the sources is viewed as equivalent (Woodward et al. 2002). The common unit of credit used in nutrient based WQT markets is expressed as a mass per unit time, most specifically pounds per year of either nitrogen or phosphorus.

\section{Trading boundary}

The nature of the water pollution restricts boundaries for nutrient credit trading. In contrast to greenhouse gas emission trading markets, the location of pollution discharges plays a crucial role in WQT trading. Non-uniformly mixed pollutants, such as nitrogen and phosphorus, do not disperse quickly and a spatial pattern of water quality damages may exist (Keudel 2006). Allowing trading between watersheds could result in better water quality in one watershed and lower water quality in the other watershed (Jarvie and Solomon 1998). The USEPA's final water quality trading policy states that "all water quality trading should occur within a watershed or a defined area for which a TMDL has been approved" (USEPA, 2003: 4).

\section{Duration of nutrient credit}

Current USEPA water quality trading policy does not mention banking of nutrient credits. The relatively temporal nature of water quality makes long-term credit banking undesirable. If a buyer purchases more than required credits this year and then uses remaining credits next year; his action have the potential to cause an impairment of water quality next year. This action is only possible under the condition where overproduction of nutrient credits occurs in the next period. Therefore, the credits purchased in one period of time should be used in 
monthly, seasonal or annual basis. Most current active WQT programs and USEPA WQT rules state that any BMP may continue to generate credits for as long as it is properly implemented and functioning (USEPA 2003).

\section{Addressing uncertainty}

Nutrient credit trading with agricultural nonpoint sources possesses greater uncertainty than trading between point sources (King 2005). Several factors such as variation in precipitation, performance of nutrient reduction practices, soil and topographical characteristics, and location differences between credit buyers and sellers in a watershed may affect the expected nutrient reduction from the nonpoint sources. The inability to address uncertainty in trades between point and nonpoint sources creates obstacle in a WQT market (Lee 2009). The literature states that this uncertainty can be minimized by setting an appropriate credit trading ratio between the point and nonpoint sources (Feng et al. 2005; Hung and Shaw 2005; King and Kuch 2003; Malik et al. 1993). Typical trading ratios used in currently active point-nonpoint trading programs ranges from $2: 1$ to $3: 1$. These ratios reflect that point sources are required to buy two or three pounds of $\mathrm{N}$ or $\mathrm{P}$ for each pound of its $\mathrm{N}$ or $\mathrm{P}$ discharge. Other instruments to address uncertainty in WQT market include maintaining a margin of safety or creation of a credit reserve pool. These instruments can help in dealing with the occurrence of any negative circumstances such as BMP failure to generate credits due to some unavoidable catastrophes.

\subsection{WQT PROGRAM FEASIBILITY ANALYSIS}

The purpose of a feasibility study is to assess the physical and economic suitability of WQT as an option for reducing nutrients discharges and improving water quality in a watershed. The previous section discusses the general requirements for establishing a WQT program. The feasibility of WQT program in a particular watershed depends not only on the legal and the 
technical provisions but also on other important factors, such as number and distribution of pollution dischargers, amount of particular pollutants discharge, potential demand for and supply of credits in the watershed, and point and nonpoint source's willingness to participate in WQT program. This section reviews the literature on such factors that are vital for feasibility of a WQT program.

\subsubsection{SOURCES AND AMOUNTS OF POLLUTION DISCHARGE}

The numbers and types of pollution dischargers in a watershed play an important role in a successful WQT market. The presence of a large number of dischargers creates divergence in abatement costs among the pollution dischargers (Pharino 2007). A limited number of dischargers may result in low volumes of nutrient credit trading in a watershed and fail to achieve pollution reduction targets. Also trading among the small number of pollution dischargers tends to increase transaction costs, economic inefficiencies or both (Stavins 1995). However, Hoag and Hughes-Popp (1997, p 254) state that "trading is feasible where there is a small number of large point sources and a fairly small number of large nonpoint sources". Their argument seems reasonable for two reasons: first, large point and nonpoint source dischargers can transact credits more effectively to each other compared to dealing with a large number of small dischargers, and second is economy of scale - the cost of pollution abatement reduces as the size of discharge increases. For example, in the Tar-Pamlico River Basin WQT program, nutrient credit trading between point and nonpoint sources is successful with a small number of point and nonpoint sources, each with large discharges.

Most of the currently active WQT programs that allow nutrient credits trading between point and nonpoint sources have a large number of potential nonpoint traders. In the Grassland Area Farmer Tradable Load Program and Lower Boise River effluent trading demonstration 
project, non-point sources have been aggregated into irrigation districts. The number of point sources in the currently active WQT programs ranges from 1 to 314 . Among the 21 active programs, 13 have less than 20 point sources. This information indicates that both the number and size of dischargers in a watershed are important determinants in WQT feasibility analysis.

\subsubsection{DEMAND AND SUPPLY OF CREDITS}

\section{Demand for Credits}

Demand for nutrient credits in WQT market is created by the regulatory imposition of a limit (nutrient cap) on pollution discharge levels from point sources. This limit on pollution discharge levels serves as a foundation for a WQT market (Boisvert et al. 2007). King and Kuch (2003) also state that the most significant factors affecting demand for nutrient discharge offsets is the level of these caps and how they are enforced. In the case of water quality markets, nutrient caps are derived from a combination of two regulatory mechanisms administered by the USEPA: the National Pollutant Discharge Elimination System (NPDES) and the Total Maximum Daily Load (TMDL). The NPDES is issued to point source dischargers that require them to maintain pollution loadings at or below a designated threshold (USEPA 1994). Permits are issued and monitored by state's environmental protection agency.

Originally, the nutrient limits specified in NPDES were technology-based standards: a facility was required to meet a pollutant output level based on available technologies at the time.

One problem with the NPDES permit system is that technology-based standards do not necessarily keep the discharge level sufficiently low to maintain acceptable water quality standards. At present, technology-based standards are being replaced by quality-based standards, which are not based on technological feasibility but on the maximum amount of pollutant that a water body can absorb and still meet designated water quality goals (USEPA 2003). 
Demand for pollutant reduction is driven by current and future loads as compared to target loads identified in the TMDLs (USEPA 2004). The TMDLs provides information about current and target loads for rivers and its tributaries. When any firm wants to produce more (or discharge more pollutants) than initial allocation, it must get pollution permits (credits) from other firms. This creates demand for pollutant reduction (via either permits or credit) in the water quality markets.

Besides regulatory limits, there are other important factors that also significantly affect the demand for nutrient credits. According to King and Kuch (2003), the demand for nutrient credits at a given price level requires at least three adjustments: (1) transaction costs - these include the costs of finding and negotiating with potential suppliers along with monitoring and validating results, (2) costs associated with accepting liability for trade risks if the nonpoint source does not perform an activity, and (3) the effect of the trading ratio. All of these factors determine the amount of nutrient credits demanded by point sources including regulatory nutrient limits.

\section{Supply Response}

Most of the literature on WQT assumes that supply follows demand. Given that nonpoint sources commonly can reduce their pollution discharge limit at lower costs than point sources; they would have economic incentive to engage in a WQT market (Boisvert et al. 2007, Shabman and Stephenson 2007, Ribaudo and Nickerson 2009). From an economic point of view, the supply of nutrient credits by nonpoint sources depends on their nutrient reduction costs (King and Kuch 2003). This nutrient reduction cost includes not only BMP implementation costs, but also any additional costs of reduced agriculture production. 
All agricultural nonpoint sources require achieving a certain defined percentage of pollution reduction before a BMP generates pollutant reduction credits. The USEPA defines a baseline requirement as a pollutant control requirement that applies to a seller in the absence of trading (USEPA 2007). These baseline requirements are either already required by law or established by a TMDL. A source generating reductions greater than the predefined percentage of current discharge can sell to the WQT markets. One study conducted by Ribaudo et al. (2009) indicates that baseline conditions in a WQT program have a profound impact on the nutrient credits supply from the nonpoint sources. As Ribaudo et al. (2009) note, "a baseline that requires a minimum level of stewardship prior to market entry will benefit those good stewards who had already adopted those practices. Poor stewards are at a distinct competitive disadvantage, and would most probably not find it in their interest to enter the market”. King and Kuch (2005) also mention that additional nutrients reductions above the baseline are relatively expensive and farmers only can supply the nutrient credits at relatively high prices.

\subsection{CURRENT WATER QUALITY TRADING PRACTICES IN THE USA}

There are 21 WQT programs that are active as of 2012 in the U.S. Four of these WQT programs are in the state of Colorado. The states of Idaho, Minnesota, North Carolina, and Ohio have two WQT programs in each state. The remaining nine WQT programs are currently active in the state of California, Connecticut, Delaware, Nevada, New Mexico, Oregon, Pennsylvania, Virginia, and Wisconsin. Table 2.1 presents trading program information by start date, state, type of water body, and trading type. 
Table 2.1: WQT Program by Start Date, State, Water Body and Trading Type

\begin{tabular}{|c|c|c|c|c|c|}
\hline S.N. & Program & Start Date & State & Water body & Trading \\
\hline 1 & $\begin{array}{c}\text { Grassland Area Farmer Tradable Loads } \\
\text { Program }\end{array}$ & 1998 & $\mathrm{CA}$ & San Joaquin River & NPS-NPS \\
\hline 2 & Bear Creek Water Quality Trading Program & 1992 & $\mathrm{CO}$ & Bear Creek Reservoir & PS-PS/NPS \\
\hline 3 & Chatfield Reservoir Trading Program & 1993 & $\mathrm{CO}$ & Chatfield Reservoir & PS-PS/NPS \\
\hline 4 & $\begin{array}{l}\text { Cherry Creek Reservoir Watershed } \\
\text { Phosphorus Trading Program }\end{array}$ & 1997 & $\mathrm{CO}$ & $\begin{array}{l}\text { Cherry Creek } \\
\text { Reservoir }\end{array}$ & PS-PS/NPS \\
\hline 5 & Lake Dillon Trading Program & 1984 & $\mathrm{CO}$ & Dillon Reservoir & PS-PS/NPS \\
\hline 6 & Long Island Sound Nitrogen Credit Program & 2002 & CT & Long Island Sound & PS-PS \\
\hline 7 & Delaware Inland Bays & 2008 & DL & $\begin{array}{c}\text { Delaware Inland } \\
\text { Bays }\end{array}$ & PS-NPS \\
\hline 8 & $\begin{array}{c}\text { Lower Boise River Effluent Trading } \\
\text { Demonstration Project }\end{array}$ & 1998 & ID & Boise River & PS-NPS \\
\hline 9 & Middle Snake River Demonstration Project & 2001 & ID & Middle Snake River & PS-PS \\
\hline 10 & Rahr Malting Nutrient Trading Program & 1997 & MN & Minnesota River & PS-NPS \\
\hline 11 & $\begin{array}{c}\text { Southern Minnesota Beet Sugar Cooperative } \\
\text { Program }\end{array}$ & 1999 & MN & Minnesota River & PS-NPS \\
\hline 12 & $\begin{array}{c}\text { Neuse River Basin Total Nitrogen Trading } \\
\text { Program }\end{array}$ & 2002 & $\mathrm{NC}$ & Neuse River Estuary & PS-PS/NPS \\
\hline 13 & Tar-Pamlico Nutrient Trading Program & 1990 & $\mathrm{NC}$ & $\begin{array}{l}\text { Pamlico River } \\
\text { Estuary }\end{array}$ & PS-PS/NPS \\
\hline 14 & Las Vegas Wash & & NE & Lake Mead & PS-PS \\
\hline 15 & Taos Ski Valley & & NM & Rio Grande River & PS-NPS \\
\hline 16 & Great Miami River Watershed Trading Pilot & 2004 & $\mathrm{OH}$ & Great Miami River & PS-PS/NPS \\
\hline 17 & Alpine Cheese Company/Sugar Creek & 2007 & $\mathrm{OH}$ & Tuscarawas River & PS-NPS \\
\hline 18 & Clean Water Services/Tualatin River & 2004 & OR & Tualatin River & PS-PS/NPS \\
\hline 19 & Pennsylvania Water Quality Trading & & & & \\
\hline 20 & $\begin{array}{l}\text { Program } \\
\text { Virginia Water Ouality Trading Program }\end{array}$ & $\begin{array}{l}2005 \\
2007\end{array}$ & $\begin{array}{l}\text { PA } \\
\text { VA }\end{array}$ & $\begin{array}{l}\text { Chesapeake Bay } \\
\text { Chesapeake Bay }\end{array}$ & $\begin{array}{l}\text { PS-PS/NPS } \\
\text { PS-PS/NPS }\end{array}$ \\
\hline 21 & $\begin{array}{c}\text { Red Cedar River Nutrient Trading Pilot } \\
\text { Program }\end{array}$ & 1997 & WI & Tainter Lake & PS-NPS \\
\hline
\end{tabular}

Source: Selman et al. 2009, Morgan and Wolverton 2005, Breetz et al. 2004

In terms of trading type, only one program allows trading between nonpoint sources (Grassland Area Farmer); three programs allow trading between point sources (Long Island Sound, Middle Snake River, and Las Vegas Wash); eight programs allow trading between point and nonpoint sources (Lake Dillon, Delaware, Lower Boise River, Rahr malting, Beet Sugar Cooperative, Taos Ski Valley, Alpine Cheese, and Red Cedar River); and nine programs allow trading between both point-point and point-nonpoint sources (Bear Creek, Chatfield Reservoir, Cherry Creek, Neuse River Basin, Tar-Pamlico, Great Miami River, Clean Water Services, Pennsylvania, and Virginia). Most of the trading programs (11 out of 21) intend to improve the water quality of rivers. Six programs aim to restore the water quality in the reservoirs/lakes, the 
remaining four programs were implemented in the watershed where large amount of nutrients and sediments delivered to inland Bay and coastal areas.

Table 2.2.2 shows WQT programs by type of pollutant trading and regulatory drivers. The most common pollutant traded in WQT programs is TP followed by TN. Of the 21 programs, 10 target only phosphorus trading (Bear Creek, Chatfield Reservoir, Cherry Creek, Lake Dillon, Delaware, Lower Boise River, Middle Snake River, Beet Sugar Cooperative, Alpine Cheese, and Red Cedar River); three target only nitrogen trading (Long Island Sound, Neuse River Basin, and Taos Ski Valley); five target both phosphorus and nitrogen trading (TarPamlico, Las Vegas Wash, Great Miami River, Pennsylvania, and Virginia); and Grassland Areas Farmer, Rahr malting, Clean Water Services, and Pennsylvania WQT programs target selenium, phosphorus/CBOD 5 , temperature, and sediments, respectively.

TMDL is the primary policy driver for most active WQT programs. More than $80 \%$ of currently active WQP programs (17 out of 21) are under a TMDL and the remaining programs (Bear Creek WQT program, Pennsylvania WQT program, Virginia WQT program, and Red Cedar River nutrient trading pilot program) are under state developed water quality control regulations. In Bear Creek, the Colorado Department of Public Health and Environment has issued Watershed Control Regulation which allocates the waste load for total phosphorus among point and nonpoint sources. The Pennsylvania and Virginia WQT programs are based on tributary strategies. These strategies allocated load limits to significant dischargers. The primary regulatory driver for point sources in Red Cedar River nutrient trading pilot program is effluent standards and limitations enforced by the Wisconsin Department of Resources. 
Table 2.2: WQ Trading Program by Type of Pollutant Trading and Regulatory Drivers

\begin{tabular}{lccc}
\hline S.N. & Program & Pollutant trading & Regulatory drivers \\
\hline 1 & Grassland Area Farmer Tradable Loads Program & Selenium & TMDL \\
2 & Bear Creek Water Quality Trading Program & Phosphorus & Watershed Control \\
& & & Regulation \\
3 & Chatfield Reservoir Trading Program & Phosphorus & TMDL \\
4 & Cherry Creek Reservoir Watershed Phosphorus & Phosphorus & Reservoir Control \\
& Trading Program & & Regulation, TMAL \\
5 & Lake Dillon Trading Program & Phosphorus & TMDL \\
6 & Long Island Sound Nitrogen Credit Program & Nitrogen & TMDL \\
7 & Delaware Inland Bays & Phosphorus & TMDL \\
8 & Lower Boise River Effluent Trading Demonstration & Phosphorus & TMDL \\
& Project & & \\
9 & Middle Snake River Demonstration Project & Phosphorus & TMDL \\
10 & Rahr Malting Nutrient Trading Program & Phosphorus/CBOD & TMDL \\
11 & Southern Minnesota Beet Sugar Cooperative Program & Phosphorus & TMDL \\
12 & Neuse River Basin Total Nitrogen Trading Program & Nitrogen & TMDL \\
13 & Tar-Pamlico Nutrient Trading Program & Phosphorus, nitrogen & TMDL \\
14 & Las Vegas Wash & Phosphorus, Ammonia & TMDL \\
15 & Taos Ski Valley & Nitrogen & TMDL \\
16 & Great Miami River Watershed Trading Pilot & Phosphorus, nitrogen & TMDL \\
17 & Alpine Cheese Company/Sugar Creek & Phosphorus & TMDL \\
18 & Clean Water Services/Tualatin River & Temperature & TMDL \\
19 & Pennsylvania Water Quality Trading Program & Phosphorus, Nitrogen, & Tributary Strategy \\
& & Sediments & Tributary Strategy \\
20 & Virginia Water Quality Trading Program & Phosphorus, Nitrogen & Administrative \\
21 & Red Cedar River Nutrient Trading Pilot Program & Phosphorus & Code \\
& & &
\end{tabular}

Sources: Selman et al. 2009, Morgan and Wolverton 2005, Breetz et al. 2004

Market size is one of the important factors in determining the success of a WQT program.

When there are fewer buyers and sellers, often called a thin market, there will be fewer opportunities for trading. While there are limited data available about market size and the number of trades occurs in each active program, Table 2.3 illustrates two indicators of market size for trading program: geographic size, and the number of sources in the watershed that can potentially be involved in trading activates. The geographic size of WQT watersheds ranges from 3,200 acres (Lake Dillon) to 6,521.6 million acres (Virginia WQT program). 
Table 2.3: WQ Trading Program by Total Area, Number of Sources, and Market Structure

\begin{tabular}{|c|c|c|c|c|}
\hline S.N. & Program & Total Area & Sources & Market Structure \\
\hline 1 & $\begin{array}{c}\text { Grassland Area Farmer Tradable Loads } \\
\text { Program }\end{array}$ & 97,000 Acres & $\begin{array}{l}7 \text { irrigation and } \\
\text { drainage districts }\end{array}$ & Bilateral \\
\hline 2 & $\begin{array}{c}\text { Bear Creek Water Quality Trading } \\
\text { Program }\end{array}$ & 83,700 Acres & 14 PSs, many NPSs & Bilateral \\
\hline 3 & Chatfield Reservoir Trading Program & 1.92 million Acres & 7 PSs, many NPSs & Sole-source offsets \\
\hline 4 & $\begin{array}{l}\text { Cherry Creek Reservoir Watershed } \\
\text { Phosphorus Trading Program }\end{array}$ & 243,000 Acres & 6 PSs, many NPSs & Sole-source offsets \\
\hline 5 & Lake Dillon Trading Program & 3,200 Acres & 4 PSs, many NPSs & Bilateral \\
\hline 6 & $\begin{array}{c}\text { Long Island Sound Nitrogen Credit } \\
\text { Program }\end{array}$ & 3.5 million Acres & 79 PSs & Clearinghouse \\
\hline 7 & Delaware Inland Bays & 320 square miles & & Sole-source offsets \\
\hline 8 & $\begin{array}{c}\text { Lower Boise River Effluent Trading } \\
\text { Demonstration Project }\end{array}$ & 41,000 Acres & $\begin{array}{l}10 \text { PSs, } 8 \text { irrigation } \\
\text { districts }\end{array}$ & Bilateral \\
\hline 9 & $\begin{array}{c}\text { Middle Snake River Demonstration } \\
\text { Project }\end{array}$ & 7.2 million Acres & 85 PSs & Bilateral \\
\hline 10 & $\begin{array}{c}\text { Rahr Malting Nutrient Trading } \\
\text { Program }\end{array}$ & - & 1 PS, many NPSs & Bilateral \\
\hline 11 & $\begin{array}{c}\text { Southern Minnesota Beet Sugar } \\
\text { Cooperative Program }\end{array}$ & - & 1 PS, many NPSs & Bilateral \\
\hline 12 & $\begin{array}{c}\text { Neuse River Basin Total Nitrogen } \\
\text { Trading Program }\end{array}$ & 3.96 million Acres & 22 PSs, many NPSs & Clearinghouse \\
\hline 13 & Tar-Pamlico Nutrient Trading Program & 2.88 million Acres & 16 PSs, many NPSs & Clearinghouse \\
\hline 14 & Las Vegas Wash & & $3 \mathrm{PSs}$ & Clearinghouse \\
\hline 15 & Taos Ski Valley & & & Sole-Source offsets \\
\hline 16 & $\begin{array}{c}\text { Great Miami River Watershed Trading } \\
\text { Pilot }\end{array}$ & 2.56 million Acres & $\begin{array}{l}314 \text { PSs, many } \\
\text { NPSs }\end{array}$ & Clearinghouse \\
\hline 17 & Alpine Cheese Company/Sugar Creek & 233,600 Acres & 1 PS, many NPSs & Bilateral \\
\hline 18 & Clean Water Services/Tualatin River & 454,400 Acres & 4 PSs, many NPSs & $\begin{array}{c}\text { Bilateral } \\
\text { Sole-source offsets }\end{array}$ \\
\hline 19 & $\begin{array}{c}\text { Pennsylvania Water Quality Trading } \\
\text { Program }\end{array}$ & 1.45 million Acres & $\begin{array}{l}142 \text { PSs, many } \\
\text { NPSs }\end{array}$ & Exchange market \\
\hline 20 & $\begin{array}{c}\text { Virginia Water Quality Trading } \\
\text { Program }\end{array}$ & 6521 million Acres & $\begin{array}{l}127 \text { PSs, many } \\
\text { NPSs }\end{array}$ & $\begin{array}{l}\text { Clearinghouse } \\
\text { Bilateral }\end{array}$ \\
\hline 21 & $\begin{array}{c}\text { Red Cedar River Nutrient Trading Pilot } \\
\text { Program }\end{array}$ & 1.92 million Acres & $\begin{array}{l}1 \text { Municipal, many } \\
\text { NPSs }\end{array}$ & Clearinghouse \\
\hline
\end{tabular}

Sources: Selman et al. 2009, Morgan and Wolverton 2005, Breetz et al. 2004

Most of the trading programs that allow nonpoint source trading have a large number of potential nonpoint traders. In the Grassland Area Farmer Tradable Load Program and Lower Boise River effluent trading demonstration project, non-point sources have been aggregated into irrigation districts. The number of point sources in a trading program ranges from 1 to 314 . For the 20 programs (except Taos Ski Valley), 13 have less than 20 point sources and seven have more than 20 point sources. 
Many WQT programs follow the bilateral market structure (Table 2.3). In a bilateral market structure, each transaction is negotiated separately based on the interaction between the buyer and the seller who exchange information and negotiate terms of trade. Nine WQT programs (the Grassland Area Farmer, Bear Creek, Lake Dillon, Lower Boise River, Middle Snake River, Rahr Malting, Beet Sugar, Alpine Cheese, and Clean Water Service) have used bilateral negotiation for nutrient credit trading. This is quite a decentralized market where risks and responsibilities are born by traders themselves. However, substantial transaction cost in this type of market can be expected (Woodward and Kaiser 2002).

Of the 21 programs, seven trading programs (Long Island Sound, Neuse River Basin, Tar Pamlico, Las Vegas Wash, Great Miami River Watershed, Virginia and Red Cedar River) rely solely on use of a clearinghouse. In this market structure, an intermediary purchases many products and sells them to buyers. The intermediary can be a state agency or any agent who purchases many non-uniform products and sells them as a uniform product. In the Long Island Sound Nitrogen Credit Program, credits are bought and sold through a Department of Environmental Protection (DEP) operated Nitrogen Credit Exchange. The exchange acts as a bank administering trades and establishing the credit values. North Carolina Wetlands Restoration Fund (NCWRF) serves as an agent for the credit trading between point sources and point and nonpoint sources in the Neuse River basin nitrogen trading program. Point sources require paying to NCWRF when their discharge exceeds the permit limit. The nonpoint source offsets are funded through the NCWRF at a fixed price of nitrogen each year. In the Tar-Pamlico PS/NPS Program, point sources pay an offset fee for each mass unit of pollutant as a group when they exceed their annual cap. These offset funds go to a voluntary agricultural cost share 
program. The state's agriculture program shares $75 \%$ of the cost of implementing best management practices (BMPs) that reduces runoff.

In the Miami River watershed nutrient trading program, Miami Conservancy District purchases and sells phosphorus and nitrogen credits. Point sources in Virginia pay a fee to state's Water Quality Improvement Fund when they exceed their discharge level. However, point sources have the option of purchasing nutrients reduction generated by other point sources or nonpoint source BMPs (bilateral market structure). Similarly, in the Red Cedar River nutrient trading pilot program, the Barron County Land Conservation Department served as a liaison with farmers. The City of Cumberland supplies funds to the farmers via Land Conservation Department to reduce loadings from their land.

Five trading programs (Bear Creek, Chatfield Reservoir, Delaware Inland Bay, Taos Ski Valley, and Clean Water Services) depend on the sole-source-offset type of market structure. In this market structure, a source is allowed to meet water quality standards at one point if pollution is reduced elsewhere. Point sources design and implement the nonpoint source offset projects and generate the credits. The Pennsylvania WQT program is the only WQT program that relies on this exchange market. Certified credits can be made available online through NutrientNet and buyers and sellers can negotiate a price and enter into a contract. Table 2.4 lists the organizations that are involved in implementing WQT programs. Eight programs (Grassland Area Farmer, Bear Creek, Chatfield Reservoir, Cherry Creek Reservoir, Las Vegas Wash, Great Miami River, Clean Water Services, and Red Cedar River WQT programs) were implemented by local organizations. The other 13 programs were implemented by state agencies related to environmental or water quality management in cooperation with local stakeholders. 
Table 2.4: WQ Trading Program by Type of Organization

\begin{tabular}{|c|c|c|}
\hline S.N. & Program & Organization \\
\hline 1 & $\begin{array}{c}\text { Grassland Area Farmer Tradable Loads } \\
\text { Program }\end{array}$ & Grassland Area Farmer \\
\hline 2 & Bear Creek Water Quality Trading Program & Evergreen Metropolitan District \\
\hline 3 & Chatfield Reservoir Trading Program & Chatfield Watershed Authority \\
\hline 4 & $\begin{array}{c}\text { Cherry Creek Reservoir Watershed Phosphorus } \\
\text { Trading Program }\end{array}$ & Cherry Creek Basin Water Quality Authority \\
\hline 5 & Lake Dillon Trading Program & $\begin{array}{c}\text { Colorado Department of Public Health and } \\
\text { Environment }\end{array}$ \\
\hline 6 & Long Island Sound Nitrogen Credit Program & Connecticut Department of Environmental Protection \\
\hline 7 & Delaware Inland Bays & $\begin{array}{c}\text { Delaware Department of Natural Resources and } \\
\text { Environmental Control }\end{array}$ \\
\hline 8 & $\begin{array}{c}\text { Lower Boise River Effluent Trading } \\
\text { Demonstration Project }\end{array}$ & Idaho Department of Environmental Quality \\
\hline 9 & Middle Snake River Demonstration Project & Idaho Department of Environmental Quality \\
\hline 10 & Rahr Malting Nutrient Trading Program & Minnesota Pollution Control Agency \\
\hline 11 & $\begin{array}{c}\text { Southern Minnesota Beet Sugar Cooperative } \\
\text { Program }\end{array}$ & Minnesota Pollution Control Agency \\
\hline 12 & $\begin{array}{c}\text { Neuse River Basin Total Nitrogen Trading } \\
\text { Program }\end{array}$ & $\begin{array}{l}\text { North Carolina Department of Environment and } \\
\text { Natural Resources }\end{array}$ \\
\hline 13 & Tar-Pamlico Nutrient Trading Program & $\begin{array}{l}\text { North Carolina Department of Environment and } \\
\text { Natural Resources }\end{array}$ \\
\hline 14 & Las Vegas Wash & Las Vegas Wash Coordination Committee \\
\hline 15 & Taos Ski Valley & New Mexico Environment Department \\
\hline 16 & Great Miami River Watershed Trading Pilot & Miami Conservancy District \\
\hline 17 & Alpine Cheese Company/Sugar Creek & \\
\hline 18 & Clean Water Services/Tualatin River & Clean Water Services \\
\hline 19 & Pennsylvania Water Quality Trading Program & Pennsylvania Department of Environmental Protection \\
\hline 20 & Virginia Water Quality Trading Program & Virginia Department of Environmental Quality \\
\hline 21 & $\begin{array}{l}\text { Red Cedar River Nutrient Trading Pilot } \\
\text { Program }\end{array}$ & City of Cumberland \\
\hline
\end{tabular}

Sources: Morgan and Wolverton 2005, Breetz et al. 2004

Trading processes are listed in Table 2.5. This table shows how point and nonpoint sources are involved in the water quality trading process. Most of WQT programs are based on the offset system. Only three programs (Grassland Area Farmer, Neuse River Basin, and TarPamlico) rely on a fee system. 
Table 2.5: WQ Trading Program by Type of WQT System and Trading Process

\begin{tabular}{|c|c|c|c|}
\hline S.N. & Program & Type & Trading \\
\hline 1 & $\begin{array}{c}\text { Grassland Area Farmer Tradable Loads } \\
\text { Program }\end{array}$ & $\mathrm{TF}$ & $\begin{array}{c}\text { Drainage districts pay a fee or receive a rebate } \\
\text { based upon achieving or not achieving their } \\
\text { allotment. }\end{array}$ \\
\hline 2 & Bear Creek Water Quality Trading Program & $\mathrm{A}, \mathrm{O}$ & $\begin{array}{c}\text { PSs formed an Association to facilitate PS to PS } \\
\text { offset. }\end{array}$ \\
\hline 3 & Chatfield Reservoir Trading Program & $\mathrm{O}$ & PS buy offsets from NPS via a clearinghouse \\
\hline 4 & $\begin{array}{c}\text { Cherry Creek Reservoir Watershed } \\
\text { Phosphorus Trading Program }\end{array}$ & $\mathrm{O}$ & PS and NPSs trade phosphorus. \\
\hline 5 & Lake Dillon Trading Program & $\mathrm{O}$ & $\begin{array}{l}\text { PS and NPSs sell credits to an authority to offset } \\
\text { phosphorus load. }\end{array}$ \\
\hline 6 & $\begin{array}{c}\text { Long Island Sound Nitrogen Credit } \\
\text { Program }\end{array}$ & A & $\begin{array}{l}\text { PS buy and sell allowances to an association to } \\
\text { achieve their regulatory requiremen.t }\end{array}$ \\
\hline 7 & Delaware Inland Bays & NA & NA \\
\hline 8 & $\begin{array}{c}\text { Lower Boise River Effluent Trading } \\
\text { Demonstration Project }\end{array}$ & $\mathrm{O}$ & $\begin{array}{l}\text { PS buy NPS reductions from a list of acceptable } \\
\text { BMPs. }\end{array}$ \\
\hline 9 & Middle Snake River Demonstration Project & $\mathrm{O}$ & NA \\
\hline 10 & Rahr Malting Nutrient Trading Program & $\mathrm{O}$ & $\begin{array}{l}\text { Rahr requires offset new load with NPS reduction } \\
\text { as part of NPDES permit. }\end{array}$ \\
\hline 11 & $\begin{array}{c}\text { Southern Minnesota Beet Sugar } \\
\text { Cooperative Program }\end{array}$ & $\mathrm{O}$ & $\begin{array}{l}\text { SMBSC requires offset new load with NPS } \\
\text { reduction as part of NPDES permit. }\end{array}$ \\
\hline 12 & $\begin{array}{c}\text { Neuse River Basin Total Nitrogen Trading } \\
\text { Program }\end{array}$ & $\mathrm{A}, \mathrm{TF}$ & $\begin{array}{l}\text { PSs issued individual and group permit. Group } \\
\text { pays fine if group permit exceeded. }\end{array}$ \\
\hline 13 & Tar-Pamlico Nutrient Trading Program & $\mathrm{A}, \mathrm{TF}$ & $\begin{array}{l}\text { PSs buy agricultural BMP credits from an } \\
\text { association if the PSs fail to meet discharge limit. }\end{array}$ \\
\hline 14 & Las Vegas Wash & NA & NA \\
\hline 15 & Taos Ski Valley & NA & NA \\
\hline 16 & $\begin{array}{c}\text { Great Miami River Watershed Trading } \\
\text { Pilot }\end{array}$ & $\mathrm{O}$ & $\begin{array}{l}\text { PSs may purchase upstream credits to comply } \\
\text { with new water standards. }\end{array}$ \\
\hline 17 & Alpine Cheese Company/Sugar Creek & $\mathrm{O}$ & $\begin{array}{l}\text { Alpine Cheese pays farmers cost of adopting } \\
\text { BMPs. }\end{array}$ \\
\hline 18 & Clean Water Services/Tualatin River & $\mathrm{O}$ & PS pays through cost-share program. \\
\hline 19 & $\begin{array}{c}\text { Pennsylvania Water Quality Trading } \\
\text { Program }\end{array}$ & $\mathrm{O}$ & $\begin{array}{l}\text { PSs buy and sell allowance; NPSs sell credits } \\
\text { when reductions are above the baseline. }\end{array}$ \\
\hline 20 & Virginia Water Quality Trading Program & $\mathrm{O}$ & $\begin{array}{l}\text { PSs buy and sell allowance; NPSs sell credits } \\
\text { when reductions are above the baseline. }\end{array}$ \\
\hline 21 & $\begin{array}{c}\text { Red Cedar River Nutrient Trading Pilot } \\
\text { Program }\end{array}$ & $\mathrm{O}$ & PSs pays to farmer through cost-share program. \\
\hline
\end{tabular}

Note: $\mathrm{A}=$ Association, $\mathrm{O}=$ Offset systems, $\mathrm{TF}=$ Tax or fee system, $\mathrm{NA}=$ not available

Most trading programs have adopted a 1:1 trading ratio for point to point credit trading and 2:1 for nonpoint to point credit trading (Table 2.6). However, some of the programs do not have a fixed trading ratio. These programs determine ratios based on location, an uncertainty discounting factor, water quality ratio, and other factors. 
Table 2.6: WQ Trading Program by Trading Ratio

\begin{tabular}{|c|c|c|c|}
\hline S.N. & Program & TR & Note \\
\hline 1 & $\begin{array}{c}\text { Grassland Area Farmer Tradable } \\
\text { Loads Program }\end{array}$ & $1: 1$ & $\begin{array}{c}\text { There is no need for a trading ratio because dischargers } \\
\text { have a single discharge location and high certainly of } \\
\text { load. }\end{array}$ \\
\hline 2 & $\begin{array}{l}\text { Bear Creek Water Quality } \\
\text { Trading Program }\end{array}$ & $1: 1-2: 1$ & $\begin{array}{l}\text { Trades between PSs use a ratio of } 1: 1 \text {, Trade ratio is } 2: 1 \\
\text { for Association Trade Projects (PS-NPS). }\end{array}$ \\
\hline 3 & $\begin{array}{c}\text { Chatfield Reservoir Trading } \\
\text { Program }\end{array}$ & $2: 1$ & $\begin{array}{l}\text { Trade Ratio is } 2: 1 \text { for all unless the applicant requests an } \\
\text { exemption of the } 2: 1 \text { trade ratio based on adequate water } \\
\text { quality data collected on a project-specific basis. }\end{array}$ \\
\hline 4 & $\begin{array}{c}\text { Cherry Creek Reservoir } \\
\text { Watershed Phosphorus Trading } \\
\text { Program }\end{array}$ & $1: 1-2: 1$ & $\begin{array}{c}\text { Trades between PSs use a ratio of } 1: 1 \text {. The minimum trade } \\
\text { ratio of } 2: 1 \text { incorporates a margin of safety to address } \\
\text { potential uncertainty associated with nonpoint source } \\
\text { reductions. }\end{array}$ \\
\hline 5 & Lake Dillon Trading Program & $1: 1-2: 1$ & $\begin{array}{c}\text { Trades between PSs use a ratio of } 1: 1 \text { and trades between } \\
\text { PS and NPSs use a ratio of } 2: 1 .\end{array}$ \\
\hline 6 & $\begin{array}{l}\text { Long Island Sound Nitrogen } \\
\text { Credit Program }\end{array}$ & $1: 1-7.7: 1$ & $\begin{array}{l}\text { The trading ratio considers the location at which the load } \\
\text { enters the watershed and the watershed enters the sound. }\end{array}$ \\
\hline 7 & Delaware Inland Bays & NA & NA \\
\hline 8 & $\begin{array}{l}\text { Lower Boise River Effluent } \\
\text { Trading Demonstration Project }\end{array}$ & vary & $\begin{array}{l}\text { Ration will vary according to a formula. Formula accounts } \\
\text { uncertainly discounting factor, location of the river, } \\
\text { location of the source, etc. }\end{array}$ \\
\hline 9 & $\begin{array}{l}\text { Middle Snake River } \\
\text { Demonstration Project }\end{array}$ & NA & NA \\
\hline 10 & $\begin{array}{l}\text { Rahr Malting Nutrient Trading } \\
\text { Program }\end{array}$ & $2: 1-10: 1$ & Trading ratios are discounted for location and distance. \\
\hline 11 & $\begin{array}{l}\text { Southern Minnesota Beet Sugar } \\
\text { Cooperative Program }\end{array}$ & 2.6:1 & $\begin{array}{l}\text { Trading ratio includes } 1.6: 1 \text { for the offset: } 1: 1 \text { for } \\
\text { environmental improvement and } 0.6: 1 \text { for other costs. }\end{array}$ \\
\hline 12 & $\begin{array}{l}\text { Neuse River Basin Total } \\
\text { Nitrogen Trading Program }\end{array}$ & $2: 1$ & $\begin{array}{l}\text { The trading ratio is embedded in the offset because new } \\
\text { dischargers must pay } 200 \% \text { of the projected cost of the } \\
\text { nonpoint source reduction. }\end{array}$ \\
\hline 13 & $\begin{array}{l}\text { Tar-Pamlico Nutrient Trading } \\
\text { Program }\end{array}$ & 2.1:1 & $\begin{array}{l}\text { The trading ratio is embedded in the offset because new } \\
\text { dischargers must pay } 200 \% \text { of the projected cost of the } \\
\text { nonpoint source reduction. }\end{array}$ \\
\hline 14 & Las Vegas Wash & & NA \\
\hline 15 & Taos Ski Valley & & NA \\
\hline 16 & $\begin{array}{l}\text { Great Miami River Watershed } \\
\text { Trading Pilot }\end{array}$ & $1: 1-3: 1$ & $\begin{array}{c}\text { The trading is based upon the water quality of the segment } \\
\text { into which the discharge occurs. }\end{array}$ \\
\hline 17 & $\begin{array}{c}\text { Alpine Cheese Company/Sugar } \\
\text { Creek }\end{array}$ & $1: 1-12: 1$ & $\begin{array}{c}\text { Trading ratio based on the source of phosphorus loading } \\
\text { and its location in the watershed relative to the Alpine } \\
\text { Cheese discharge location. }\end{array}$ \\
\hline 18 & $\begin{array}{c}\text { Clean Water Services/Tualatin } \\
\text { River }\end{array}$ & $1: 1-2: 1$ & $\begin{array}{c}\text { Trading ratio } 2: 1 \text { for stream over } 7 \text { feet across and } \\
\text { duration of credit establishment- } 20 \text { years. Trading ratio } \\
\text { 1:1 for stream over } 7 \text { feet across and under and duration of } \\
\text { credit establishment }-10 \text { years. }\end{array}$ \\
\hline 19 & $\begin{array}{c}\text { Pennsylvania Water Quality } \\
\text { Trading Program }\end{array}$ & $1: 1-3: 1$ & $\begin{array}{l}\text { The trading ratio fixed based on delivery ratio, uncertainty } \\
\text { ratio, water quality ratio ( } 10 \% \text { of credit), and retirement } \\
\text { ratio ( } 10 \% \text { of credit). }\end{array}$ \\
\hline 20 & $\begin{array}{c}\text { Virginia Water Quality Trading } \\
\text { Program }\end{array}$ & $1: 1$ & NA \\
\hline 21 & $\begin{array}{l}\text { Red Cedar River Nutrient } \\
\text { Trading Pilot Program }\end{array}$ & $2: 1$ & Trading ratio is for net environmental improvement. \\
\hline
\end{tabular}

Sources: Morgan and Wolverton 2005, Breetz et al. 2004 
All participants of the trading programs are subject to legal action when they are in violation of compliance with terms of a trade. Table 2.7 presents WQT programs by penalty and liability practiced. Existing WQT programs use four mechanisms for ensuring compliance: discharge monitoring, stream monitoring, physical inspection, and private contracts.

Table 2.7: WQ Trading Program by Penalty and Liability

\begin{tabular}{|c|c|c|}
\hline S.N. & Program & Penalty and liability \\
\hline 1 & $\begin{array}{c}\text { Grassland Area Farmer Tradable Loads } \\
\text { Program }\end{array}$ & $\begin{array}{l}\text { Trades are retroactive, based upon monitoring, and } \\
\text { involve a fee and rebate policy. }\end{array}$ \\
\hline 2 & Bear Creek Water Quality Trading Program & $\begin{array}{l}\text { Legal action. Failure of PSs to satisfy the discharge limit } \\
\text { is a violation of NPDES permit. }\end{array}$ \\
\hline 3 & Chatfield Reservoir Trading Program & $\begin{array}{c}\text { Legal action. The credits are incorporated in the NPDES } \\
\text { permit. }\end{array}$ \\
\hline 4 & $\begin{array}{c}\text { Cherry Creek Reservoir Watershed } \\
\text { Phosphorus Trading Program }\end{array}$ & $\begin{array}{c}\text { Legal action. Pont sources are incorporated in the } \\
\text { NPDES permit. }\end{array}$ \\
\hline 5 & Lake Dillon Trading Program & Legal action. NPDES permit reflects NPS control. \\
\hline 6 & Long Island Sound Nitrogen Credit Program & $\begin{array}{l}\text { Legal action. Failure is a violation of group permit. } \\
\text { Payments are for participation. }\end{array}$ \\
\hline 7 & Delaware Inland Bays & NA \\
\hline 8 & $\begin{array}{l}\text { Lower Boise River Effluent Trading } \\
\text { Demonstration Project }\end{array}$ & Legal action. PS is liable and sign PC with NPS. \\
\hline 9 & Middle Snake River Demonstration Project & \\
\hline 10 & Rahr Malting Nutrient Trading Program & $\begin{array}{c}\text { Legal action. PS inspects BMPs, signs contract with } \\
\text { NPS, and maintains liability. }\end{array}$ \\
\hline 11 & $\begin{array}{c}\text { Southern Minnesota Beet Sugar Cooperative } \\
\text { Program }\end{array}$ & $\begin{array}{l}\text { Legal action. PS inspects BMPs, signs contract with } \\
\text { NPS, and maintains liability. }\end{array}$ \\
\hline 12 & $\begin{array}{c}\text { Neuse River Basin Total Nitrogen Trading } \\
\text { Program }\end{array}$ & $\begin{array}{c}\text { Legal action, fee, or rebate. The association pays fee for } \\
\text { group failure. }\end{array}$ \\
\hline 13 & Tar-Pamlico Nutrient Trading Program & $\begin{array}{c}\text { Legal action and fee. State assumes responsibility for } \\
\text { verification of BMPs. }\end{array}$ \\
\hline 14 & Las Vegas Wash & NA \\
\hline 15 & Taos Ski Valley & NA \\
\hline 16 & Great Miami River Watershed Trading Pilot & $\begin{array}{l}\text { Legal action. PS and NPS develop an agreement. } 5 \%- \\
10 \% \text { of sites are inspected. }\end{array}$ \\
\hline 17 & Alpine Cheese Company/Sugar Creek & $\begin{array}{l}\text { Legal action. PS inspects BMPs, signs contract with } \\
\text { NPS, and maintains liability. }\end{array}$ \\
\hline 18 & Clean Water Services/Tualatin River & $\begin{array}{l}\text { Legal action. PS inspects BMPs, signs contract with } \\
\text { NPS, and maintains liability. }\end{array}$ \\
\hline 19 & $\begin{array}{c}\text { Pennsylvania Water Quality Trading } \\
\text { Program }\end{array}$ & $\begin{array}{l}\text { Legal action. Pont sources are incorporated in the } \\
\text { NPDES permit. }\end{array}$ \\
\hline 20 & Virginia Water Quality Trading Program & $\begin{array}{l}\text { Legal action. Pont sources are incorporated in the } \\
\text { NPDES permit. }\end{array}$ \\
\hline 21 & $\begin{array}{c}\text { Red Cedar River Nutrient Trading Pilot } \\
\text { Program }\end{array}$ & $\begin{array}{l}\text { Legal action. Pont sources are incorporated in the } \\
\text { NPDES permit, Barron County Land Conservation } \\
\text { Department served as a liaison with farmers, signing } \\
\text { farmers up for trading and verifying BMPs. }\end{array}$ \\
\hline
\end{tabular}

Sources: Morgan and Wolverton 2005, Breetz et al. 2004. Note: NPDES = National Pollution Discharge Elimination System, NPS $=$ Non-Point Source, $\mathrm{PC}=$ Point Source, NA $=$ not available, $\mathrm{PC}=$ Personal Contract, $\mathrm{BMPs}=$ Best Management Practice. 
All trading programs implement a discharge monitoring system by continuous monitoring of effluent. Trades involving point sources can use the monitoring results from NPDES permits to assist with verification of compliance. Many programs have adopted other mechanisms for ensuring compliance. Stream monitoring (e.g. Chatfield Lake, Great Miami River) involves sampling the water ways to determine nutrient, sediment or temperature levels in the water bodies. Physical inspection (e.g. Cherry Creek, Great Miami River, Lake Dillon, Lower Boise River, Rahr Malting, Beet Sugar, Red Cedar, and Tar-Pamlico) involves site visits to verify the condition of a facility. This mechanism is applied for trades between point and nonpoint sources that involve BMPs. Some trading programs (Rahr malting, Beet Sugar, Lower Boise River, and Great Miami River WQT programs) use an outside contractor to monitor the responsibilities of the parties in trade.

\subsection{WATER QUALITY MODELING}

Multiple uses of water resources create many environmental problems that need to be addressed through water resource planning and development of effective management strategies. Water pollution from agricultural and non-agricultural sources, soil erosion, flooding, and deterioration of surface water bodies are some of the environmental problems which need to be addressed for sustainable water resource management. In response to severe water quality problems in streams, rivers, lakes, estuaries, and coastal waters, the U.S. government has approved and implemented the 1956 Federal Water Pollution Control Act, including the Clean Water Act and amendments of 1972, 1977, 1981, and 1987. These regulatory frameworks are the primary drivers for the development of watershed models in the U.S. (Ambrose et al. 2009). Many governmental and non-governmental organizations have been involved in the development of watershed-based, water quality models. Among them, the USEPA has played a leading role in 
the development and use of water quality models collaborating with other federal and state agencies. Public teaching and research institutions, and private consulting firms have also contributed in the development of the models (Singh and Frevert 2006).

The development of water quality models is directly related to the advancement of computer technology. During late 1970s to mid-1980s, the USEPA and U.S. Army Corps of Engineers developed many water quality models using DOS based microcomputers. These models were developed for rivers, lakes, and estuaries by linking hydrodynamic and water quality models (Ambrose et al. 2009). The development of Windows Operating Systems during 1990s helped to include the graphical user interfaces (GUIs) including GIS and internet linkages in water quality models. Most current advanced water quality models include a diversity of pollutant sources and are of capable conducting sensitivity and uncertainly analyses in a short period of time using powerful desktop computers. These models consider a wide range of information to simulate the movement of pollutants from the various sources to receiving waters in a watershed. Models include meteorological, agricultural, soil, geologic, and hydrologic data in the simulation process.

Until the early 1980s, controlling point source pollution from waste water treatment plants and industrial facilities received the primary focus in protection of surface water quality. Starting in the late 1980s, nonpoint sources of pollution such as urban and agricultural runoff were considered the greatest remaining threats to surface water quality and beneficial uses (USEPA 1989). These threats have led to the development of many point and nonpoint source water quality models, which have supported the design of cost-effective watershed management plans including TMDLs. These models integrate GIS technology and environmental databases to simulate and estimate water pollution from different sources, spatial locations, and land use 
practices (Karigomba 2009). Results of these models provide estimates of the total amount of pollutants entering to a water body from multiple sources and can be used to allocate pollution loads among sources. Models are also used to predict changes in the current state of pollution discharges from particular sources when certain initial conditions are altered.

In the last few decades, researchers have used a wide range of water quality models including a combination of scientific, economic, and social data. All models have contributed significantly to water resource management related decision-marking. Currently widely used models are: WASP (Water Quality Simulation Program), HSPF (Hydrologic Simulation Program), SWAT (Soil and Water Assessment Tool), and SPARROW (SPAtially Referenced Regressions On Watershed attributes). Other water quality models used for modeling of surface water quality include WCMS (Watershed Characterization and Modeling Software) and MapShed. All models have their own advantages and disadvantages and each model can be used for a specific purpose. The majority of currently applied models integrate GIS technology, environmental databases, analytical tools, and modeling programs to support the development of cost-effective watershed management plans. In the following section, some water quality models relevant for this study are briefly reviewed.

\subsubsection{WASP (Water Quality Analysis Simulation Program)}

The water quality analysis simulation program (WASP) is a dynamic compartmentmodeling program used for modeling the surface water quality (Wool et al. 2004, Amborse et al. 1987). This multi-dimensional model allows for simulation of multiple water quality parameters. The model can predict nutrients and sediments, phytoplankton, periphyton, organic matter, and dissolve oxygen (Ambrose et al. 2009). 
The WASP model has been used to examine water quality in several water bodies. The model was used to examine eutrophication of river and reservoirs, bays, estuaries, and nutrients loadings to the rivers and lakes (USEPA 2012). The model is primarily used to support the estimation of TMDL and waste load allocations for pollutant sources in a watershed. This model can be useful for modeling agricultural sources. However, this model requires large data sets and high level of expertise. The model has been found to slightly under-predict upstream and overpredict downstream nitrogen concentrations (Kaufman 2011).

\subsubsection{HSPF (Hydrologic Simulation Program-Fortran)}

HSPF can simulate watershed hydrology and associated water quality for both conventional and toxic organic pollutants in the surface waters (Bicknell et al. 1996). The HSPF model incorporates watershed-scale Agricultural Runoff Model (ARM) and Non-Point Source (NPS) models in a basin-scale analysis framework. This model simulates a wide range of pollutants including nitrogen, phosphorus, sediments, BOD, temperature, and toxic substances. The model is generally used to assess the effects of land use change, reservoir operations, point and non-point source treatment alternatives, etc. (Deliman et al. 1999). This model also requires detailed metrological data and land and water related parameters. A comparison of water quality models by Im et al. (2003) indicates that HSPF is not user-friendly due to numerous parameters to control and represent the hydrologic cycle, sediment and nutrients transport.

\subsubsection{SWAT (Soil and Water Assessment Tool)}

SWAT was developed by Dr. Jeff Arnold for the USDA Agricultural Research Service (ARS) in the early 1990s to predict the impact of land management practices on water quality over long periods of time. This model requires specific information about weather, soil properties, topography, vegetation, and land management practices occurring in the watershed 
(Neitsch et al. 2011). The model was developed to assist water resource managers in assessing the impact of management and climate on water supplies and non-point source pollution in watersheds (Arnold and Fohrer 2005). Some recent WQT feasibility studies have used SWAT model for non-point source modeling (CTIC 2011, Lee 2009, Kieser and Associates 2004). While SWAT is widely used for water quality modeling, it is considered as a complex model that incorporates many interrelated watershed processes which requires some level of expertise for its application.

\subsubsection{SPARROW (SPAtially Referenced Regressions On Watershed attributes)}

SPARROW is a watershed modeling technique to estimate pollutant discharges from various sources in the surface waters. This model was developed by Smith and others in 1997 and employs statistically estimated nonlinear regression models to predict surface water quality in the watershed (Smith et al. 1997). The model requires data on pollutant sources (e.g., atmospheric deposition, fertilizers, human and animal wastes) along with climatic and hydrogeologic parameters (e.g., precipitation, topography, vegetation, soils, water routing). SPARROW has been applied to the analysis of sources and transport of surface-water nutrients, pesticides, suspended sediment, organic carbon, and fecal bacteria. Federal and state environmental managers are using SPARROW to assess the sources of nutrient loadings in streams as well as for developing TMDLs in the watersheds (Schwarz et al. 2006). SPARROW is SAS software based model which requires some level of SAS programming knowledge for model executions.

\subsubsection{WCMS (Watershed Characterization and Modeling Software)}

WCMS was developed by West Virginia University Natural Resources Center (NRAC) for stream and river water quality modeling in West Virginia. The model is based on a 
hydrologically corrected digital elevation model for stream flow modeling, calculating drainage area, estimating cumulative flow of pollution, fate and transportation of pollution, expected mean concentration (EMCs), and distance calculation (NRCS 2007). It can be used to estimate concentrations and loadings of nitrogen $(\mathrm{N})$, phosphorous $(\mathrm{P})$, and total suspended solids (TSS) in the streams and rivers from the various sources. The West Virginia Department of Environmental Protection (WVDEP) is currently using WCMS to design policies for water quality management throughout the state (Strager et al. 2010).

\subsubsection{MapShed}

MapShed is an extended version of the Generalized Watershed Loading Function (Evans et al. 2002) which can be used to model sediment and nutrient transport within a watershed (Evan and Corradini 2012). The watershed simulation tools used in MapShed are based on the Generalized Watershed Loading Function (GWLF) and RunQual models originally developed by Haith and Shoemaker (1987). This model is a lumped parameter watershed model that simulates monthly nutrient and sediment loads from both point and nonpoint sources. This model is characterized as a "mid-range" model for watershed assessment and TMDL development (USEPA 1997). This model was originally applied and tested on the West Branch Delaware River at Walton, New York (Haith and Shoemaker 1997). The model has been applied to water quality modeling in different watersheds such as Cannonsville Reservoir Watershed, New York (Schneiderman et al. 2002), Choptank River Basin, Maryland (Lee et al. 2000), and New York City watersheds (Rao et al. 2009).

The Pennsylvania Department of Environmental Protection (PDEP) has adopted GWLF to support ongoing TMDL estimation within Pennsylvania (Evans et al. 2002). This model is easy to use and relies on data input that is generally less exotic and easier to compile than other 
watershed models such as SWAT and HSPF (Deliman et al. 1999). Many watershed models require water quality monitoring data for model calibration. The MapShed model is one such model that can be used without calibration and has been widely used throughout the Northeast of US (Evan and Corradini 2012). In many watersheds, this model requires minimum calibration for water quality modeling (Haith et al. 2009).

The GWLF-E in the MapShed can simulate nutrient ( $\mathrm{N}$ and $\mathrm{P}$ ) and sediment loadings from a watershed from the various sources. MapShed includes the PRedICT tool which can be used to evaluate the implementation of both agricultural and non-agricultural pollution reduction strategies at the watershed scale. This tool allows the user to create various agricultural BMPs scenarios to predict current and future nutrient and sediment loadings in the watershed. The tool also can predict the nutrient load reductions from the various wastewater treatment plant upgrades. It uses daily weather data (temperature and precipitation), land use/cover, soil map, stream network, digital elevation model, and other parameters to estimate monthly sediment and nutrients discharges from a watershed (Haith et al. 1992, Evans et al. 2002, Evan and Corradini 2012). This model requires minimum calibration for water quality modeling in the watershed (Haith et al. 2009). 


\section{CHAPTER 3: THEORETICAL BACKGROUND AND MODEL}

\subsection{INTRODUCTION}

Environmental economists have been involved in developing alternative policy instruments to deal with environmental problems that can be economically efficient, ecologically effective, and politically feasible. Market-based policy instruments for improving air and water qualities, enhancing wildlife habitats, and conserving other ecosystem services are receiving interest as efficient, effective, and convenient tools (Miller 2010, Serre 2008, Tietenberg 2007). This section discusses market market-based instruments for pollution control, introduces a theoretical model of water quality trading, and economic models of point and non-point sources.

\subsection{MARKET-BASED INSTRUMENTS FOR POLLUTION CONTROL}

It is generally accepted that rational and self-interested individuals in a free market interact with each other for the exchange of goods and services, which leads to efficient allocation of resources. The efficient allocation of resources indicates a situation in which no one can be made better off unless someone is made worse off, which is commonly known as "pareto optimal" condition. This ideal market does not exist for all kinds of goods and services. Consequently, efficiency in resource allocation may not be achieved and price signals do not reflect actual costs and benefits of production and consumptions of the goods and services in the economy. The term "market failure" or "market distortions" is widely used to describe this scenario in economics. Common reasons of market failure or distortions are the presence of public goods or externalities (Miller 2010).

Public goods are non-excludable and non-rival. Such characteristics of goods can cause market failure as people have a low incentive to pay for the goods (Cornes and Sandler 1996). 
Externalities occur when production or consumption of private or public goods can generate external benefits or costs to the good producer or consumer. From economic point of view, these externalities impacts on the profit or utility of a third party that would be unintended. If the production or consumption activities of one individual adversely impact on other, it is termed as negative externality. Water and air pollution are primary examples of negative externalities. Economists have been involved in designing policies to internalize such externalities in the production or consumption processes in the market economy.

Market-based instruments, which are more efficient and flexible for pollution control, have emerged as an alternative to traditional regulatory approaches (Tietenberg 1990). They can address pollution problems by altering the behavior of the pollution dischargers through incorporating the costs of pollution damages in the production process (Jenkins and Lamech 1992). This will internalize the negative externalities and encourage the dischargers to reduce pollution.

\subsection{THEORETICAL MODEL OF WATER QUALITY TRADING}

The economic objective of environmental regulatory design is one of cost effectiveness where the aim is to achieve a target level of pollution or equivalent pollution abatement at the lowest possible cost. Using economic optimization methods, a desired level of pollution abatement for uniformly mixed pollutants is achieved at the point where the marginal costs are equated across all pollution sources (Tietenberg 2006). In the case of non-uniform mixing pollutants (e.g. nitrogen and phosphorus in water), this general assumption is inappropriate. The concentration of pollutants in a water body depends on both the level of discharges and the location of dischargers relative to receptor sites. Due to dilution, dispersion, and other biophysical interactions, the impact on ambient levels of a pollutant at a given receptor are 
expected to decline as the distance between the discharger and the receptor increases (Boisvert et al. 2007). Thus, a cost-effective solution for non-uniform mixing pollution can be achieved at the point where marginal costs of concentration reduction at each receptor location that are equalized (Tietenberg 2006).

Similar to air quality trading (e.g. $\mathrm{CO}_{2}, \mathrm{SO}_{2}$ ), differences in marginal abatement costs across the pollution sources plays a fundamental role in determining the direction and amount of trade, and magnitude of gains from pollution trading in a WQT market (Shortle 1987; Letson 1992). Pollution trading allocates reductions in pollutants loadings across discharge sources in a watershed using a least-cost criterion, allowing sources with high marginal abatement costs to purchase pollution credits from sources that have lower marginal abatement costs, thereby reducing the overall abatement costs of desired water quality improvement (Malik et al. 1993). The theoretical model of WQT is based on this basic principle of pollution trading.

Consider that a given water quality problem in a watershed is caused by both point source discharges and nonpoint source runoff. The point source discharges are non-stochastic and measurable. But nonpoint source runoff is stochastic and cannot be accurately measured at reasonable cost. Runoff depends on land management practices, environmental variables (e.g. weather), and site characteristics (e.g. soil type, topography) (Shortle et al. 1998). Researchers have developed models which estimate the expected pollution discharges from the nonpoint sources utilizing information on farm management practices, weather, soil characteristics, and other relevant factors. These models include the Soil and Water Assessment Tool (SWAT) (Neitsch et al. 2002), Watershed Characterization and Modeling System (WCMS) (Strager et al. 2010), and MapShed (Evans and Corradini 2012). While these models cannot provide a perfect 
substitute for accurate direct monitoring, they can serve as an appropriate tool for making decisions about the allocation of pollution abatement across numerous sources.

Following the cost-effectiveness pollution control models proposed by Shortle et al. (1998) and Horan et al. (2004), assume that a particular river or lake is polluted by a single pollutant $(\mathrm{N}$ or $\mathrm{P})$. The ambient concentration of pollution, $a$, depends on point source discharges, $e_{k}(k=1, \ldots \ldots, n)$, runoff from nonpoint sources, $r_{i}(i=1, \ldots, m)$, natural generation of the pollution, $\mathrm{g}$, stochastic environmental variables that influence transport and fate, $\gamma$, and watershed characteristics and parameters, $\lambda$.

$$
\begin{aligned}
& a=a\left(e_{1}, e_{2}, \ldots ., e_{n}, r_{1}, r_{2}, \ldots . . r_{m}, g, \gamma, \lambda\right) . \\
& \text { Where } \frac{\partial a}{\partial r_{i}} \geq 0 \forall_{i}, \frac{\partial a}{\partial e_{k}} \geq 0 \forall_{j}
\end{aligned}
$$

For simplicity, let's consider a water quality damage cost function, D $(a)$, which is continuous and increasing. However, the damage function or abatement cost function may not be continuously increasing in all the cases (Perman et al. 2003 p.188). The expected damage cost constraint is:

$$
E\{D(a)\} \leq T
$$

Where $\mathrm{T}$ is target level of water quality set by a regulatory agency.

The total cost of reducing pollution discharges from point sources is an increasing function of the level of pollution abatement. The $k^{\text {th }}$ point source expected pollution control costs would be a function of abatement, denoted by $e_{k 0}-e_{k}$, where $\mathrm{e}_{\mathrm{k} 0}$ is base level of pollution discharge. The abatement costs as a function of pollution discharges can be $c_{e k}\left(m_{k}\right)$. Where, $m_{k}$ is an abatement activity implemented by a point source. Assume that all point sources directly discharge their effluent into the water body so that stochastic environmental variables and site specific characteristics do not influence the expected loadings from point sources. 
The expected loadings from nonpoint sources depend on the inputs used in the production process (let $x_{i}$ denote a vector of all inputs including land, fertilizer, pesticides, agronomic practices, and practices undertaken specifically to control pollution runoff from the agricultural land), stochastic environmental variables, $\gamma$, site-specific characteristics, $\lambda$. The expected loading from farm $i$ in a particular location is: $r_{i}=r_{i}\left(x_{i}, \gamma_{i}, \lambda_{i}\right)$. Let $\pi_{r i}\left(x_{i}\right)$ denote the economic returns to the $i^{\text {th }}$ farm from the choice of input vector $\mathrm{x}$. The total cost of pollution control for each nonpoint source can be defined as the reduction in net economic returns from the application of nonpolluting method or pollution control practices (Freeman 2003). Thus, the nonpoint source pollution control cost function can be represented as:

$$
c_{r i}\left(x_{i}\right)=\pi_{r i}^{*}-\pi_{r i}\left(x_{i j}\right)
$$

Where $\pi_{r i}^{*}$ total economic return under without pollution control condition and $\frac{\partial c_{\mathrm{ri}}}{\partial \mathrm{x}_{\mathrm{ij}}}=-\frac{\partial \pi_{\mathrm{ri}}}{\partial \mathrm{x}_{\mathrm{ij}}}$. A cost effective allocation of pollution control efforts minimizes the sum of private control costs and expected damage costs in a watershed. Thus the least-cost allocation solves:

$$
\begin{gathered}
{\underset{w_{k}}{\operatorname{Min} x_{i j}} T C=} \sum_{k=1}^{m} c_{e k}\left(m_{k}\right)+\sum_{i=1}^{n} c_{r i}\left(x_{i j}\right) \\
\text { Subject to } E\{D(a)\} \leq T
\end{gathered}
$$

With appropriate continuity and convexity assumptions, first order conditions for this problem are:

$$
\begin{gathered}
\frac{\partial c_{e k}\left(e_{k}\right)}{\partial m_{k}}=\lambda E\left\{D^{\prime}(a) \frac{\partial a}{\partial e_{k}} \frac{\partial e_{k}}{m_{k}}\right\} \ldots \\
\frac{\partial c_{r i}\left(x_{i j}\right)}{\partial x_{i j}}=\lambda E\left\{D^{\prime}(a) \frac{\partial a}{\partial r_{i}} \frac{\partial r_{i}}{x_{i j}}\right\} \ldots
\end{gathered}
$$

Condition (3.5) equates the marginal cost and expected marginal damages that result from point source's abatement activity. Similarly, condition (3.6) equates the marginal cost and expected marginal damages that result from nonpoint source abatement activity. Conditions (3.5) 
and (3.6) indicate total cost of pollution reduction in a watershed can be achieved at condition where marginal cost of abatement is equal to expected marginal damages.

The expected marginal damage function can be equivalently interpreted as expected benefit function. For both point and nonpoint sources as the amount of allowable discharge level rises, they can avoid the pollution abatement costs and make cost savings. Thus, for given level of output, the larger is the amount of pollution discharges, the greater will be the cost savings. Symbolically, it can be represented by the function $E\{B(a)\}$. Similar to conditions (3.5) and (3.6), the net benefits of pollution reduction can be maximized only where the marginal benefits of pollution equal the marginal damage of pollution, $\frac{\partial B(a)}{\partial(a)}=\frac{\partial D(a)}{\partial(a)}$.

\subsection{MODELING POINT SOURCES}

A point source (such as a WWTP) is assumed to discharge pollution directly into the water body and it controls discharges by selecting wastewater treatment technologies. Let $w_{k 0}^{i}$ denote the total quantity of water inflow to the firm i's treatment plant and $e_{k 0}^{i}$ denote the nutrient concentration of the inflow water. The total amount of nutrient inflow to the firm $i^{\text {th }}$ treatment plant is $e_{k 0}^{i} w_{k 0}^{i}$. Similarly, $w_{k 1}^{i}$ denotes the total quantity of water outflow from the $i^{\text {th }}$ firm following treatment with technology $k_{1}$ and $e^{i}{ }_{k 1}$ denote the nutrient concentration of the outflow water. The total amount of nutrient outflow from the $i^{\text {th }}$ firm after treatment is $e^{i}{ }_{k 1} w^{i}{ }_{k 1}$. The firm faces the abatement cost, $C_{e k}\left(\mathrm{e}_{\mathrm{k} 1}^{\mathrm{i}} \mathrm{w}_{\mathrm{k} 1}^{\mathrm{i}}\right)$, which depends directly on the nutrient reductions. This is a continuous, twice differentiable function and $C^{\prime}>0$ and $C^{\prime \prime}>0$. An nutrient discharge cap is set below the current discharge level for this firm so that the total discharge cannot exceed firm's mandated pollution discharge level, $q_{m}^{i}$. The firm i now aims to minimize its abatement cost subject to the set discharge constraint.

$$
\operatorname{Min} C_{e k}\left(e_{k 1}^{i} w_{k 1}^{i}\right)
$$


Subject to

$$
e_{k 1}^{i} w_{k 1}^{i} \leq q_{m}^{i}
$$

and

$$
e_{k 1}^{i} \geq 0
$$

The constraint (3.2) shows that the amount of total emissions must not exceed the set discharge limit. This minimization problem can be solved by using the Kuhn-Tucker conditions.

$$
L=C_{e k}\left(\mathrm{e}_{\mathrm{k} 1}^{\mathrm{i}} \mathrm{w}_{\mathrm{k} 1}^{\mathrm{i}}\right)+\lambda\left(q_{m}^{i}-\mathrm{e}_{\mathrm{k} 1}^{\mathrm{i}} \mathrm{w}_{\mathrm{k} 1}^{\mathrm{i}}\right)
$$

By differentiating this with respect to $\mathrm{e}_{\mathrm{k} 1}^{\mathrm{i}}$ we get the Kuhn-Tucker conditions for the optimum:

$$
\begin{aligned}
& \frac{\partial C_{e k}\left(e_{k 1}^{i} w_{k 1}^{i}\right)}{\partial e_{k 1}^{i}}-\lambda \geq 0, \quad e_{k 1}^{i}\left[C^{\prime}{ }_{e k}\left(e_{k 1}^{i} w_{k 1}^{i}\right)-\lambda\right]=0 \\
& e_{k 1}^{i} w_{k 1}^{i} \leq q_{m}^{i}, \quad \lambda\left[e_{k 1}^{i} w_{k 1}^{i}-q_{m}^{i}\right]=0 \\
& e_{k 1}^{i} \geq 0 ; \lambda \geq 0
\end{aligned}
$$

The $\lambda$ represents the marginal abatement costs (MAC) of the firm, expressed as $\frac{\partial C_{e k}\left(\mathrm{e}_{\mathrm{k} 1}^{\mathrm{i}} \mathrm{w}_{\mathrm{k} 1}^{\mathrm{i}}\right)}{\partial \mathrm{e}_{\mathrm{k} 1}^{\mathrm{i}}}$. This $\lambda$ is positive only when the nutrient discharge constraint (3.2) is binding.

Let us assume that nutrient trading market exist in the watershed and firm i can purchase nutrient credits, $q_{d}^{i}$, from other sources. Now, the $\mathrm{i}^{\text {th }}$ firm's total discharge is:

$$
e_{k 1}^{i} w_{k 1}^{i} \leq q_{m}^{i}+q_{d}^{i}
$$

Where $q_{d}^{i}=e_{k 1}^{i} \mathrm{w}_{\mathrm{k} 1}^{\mathrm{i}}-q_{m}^{i}$

The total cost of firm is:

$$
C_{e k}\left(\mathrm{e}_{\mathrm{k} 1}^{\mathrm{i}} \mathrm{w}_{\mathrm{k} 1}^{\mathrm{i}}\right)+p\left(e_{k 1}^{i} \mathrm{w}_{\mathrm{k} 1}^{\mathrm{i}}-q_{m}^{i}\right)
$$

Where, $C_{e k}$ is the cost of operating the $k^{\text {th }}$ technology and $p$ is the per unit price of nutrient credit that prevails in the WQT market. It is assumed that the total quantity of water inflow to the firm $i$ 's treatment plant and the total quantity of water outflow from the $i^{\text {th }}$ firm following treatment 
with technology $\mathrm{k}_{1}$ remains the same. Now the firm faces the problem of minimizing total costs which consists of abatement costs and cost of nutrient credits as follows:

$$
\begin{aligned}
& \operatorname{Min} C_{e k}\left(\mathrm{e}_{\mathrm{k} 1}^{\mathrm{i}} \mathrm{w}_{\mathrm{k} 1}^{\mathrm{i}}\right)+p\left(e_{k 1}^{i} \mathrm{w}_{\mathrm{k} 1}^{\mathrm{i}}-q_{m}^{i}\right) \\
& \text { Subject to } \quad e_{k 1}^{i} w_{k 1}^{i} \leq q_{m}^{i}+q_{d}^{i} \ldots \ldots \ldots \\
& \text { and } \quad e_{k 1}^{i} \geq 0 \ldots \ldots \ldots \ldots \ldots \ldots
\end{aligned}
$$

The constraint (3.11) shows that the amount of total nutrient discharge from the firm i must not exceed the mandated amount of nutrient discharge plus amount of nutrient credits purchased in the WQT market. The solution for the minimizing problem can be reached by solving following Kuhn-Tucker conditions:

$$
\begin{gathered}
\frac{\partial C_{e k}\left(e_{k 1}^{i} w_{k 1}^{i}\right)}{\partial e_{k 1}^{i}}-p \geq 0 \ldots \ldots \\
e_{k 1}^{i}\left[C^{\prime}{ }_{e k}\left(e_{k 1}^{i} w_{k 1}^{i}\right)-p\right]=0 \\
e_{k 1}^{i} \geq 0 \ldots \ldots \ldots \ldots \ldots \ldots \ldots \ldots \ldots
\end{gathered}
$$

A comparison of equations 3.5 through 3.7 with equations 3.13 through 3.15 shows that $p=\lambda=$ MAC to be a sufficient condition for this cost minimization problem. All participating firms make decisions about how many of nutrient credits they would buy based on their own MAC and market price of nutrient credit. If the credit price drops, then each firm purchases more credits and at the same time controls less amount of pollution. Thus, the firm's MAC curve represents nutrient credit demand function which can be represented by $q_{d}^{i}\left(p, e_{k 1}^{i}\right)$. The market-level demand for nutrient credits can be obtained by aggregating individual point source's demands: $D(p)=\sum_{i} q_{d}^{i}\left(p, e_{k 1}^{i}\right)$ 


\subsection{MODELING AGRICULTURAL SOURCES}

Building on the model of Peterson et al. (2005), assume that agricultural production exhibits constant returns to scale which can be expressed in per acre term. Let, $y=y_{1}, y_{2} \ldots \ldots . . y_{J}$ denote a vector of yields of $J$ crops, $x=x_{1}, x_{2}, \ldots \ldots x_{k}$ denotes a vector of $\mathrm{K}$ inputs, $\mathrm{p}$ and $\mathrm{s}$, are vector of output and input prices. Total cost of crop production is denoted by $c$. Profit for a farm in the absence of pollution abatement is:

$$
\pi_{i}^{*}=p y-c_{i}\left(x_{i}\right)
$$

Pollution discharges are generated based on the level of inputs $(x): r_{i}^{*}=r_{i}\left(x_{i}\right)$. In the absence of pollution controls, firm chooses zero abatement and produces $y^{*}$ level of output discharging $r^{*}$ level of pollution.

Farms can reduce the pollution discharge through three general techniques. First, discharge can be reduced by reducing the scale of output. Second, by adopting pollution reduction agronomic practices (e.g. conservation tillage, cover crops, contour strip-cropping, and contour farming) or the input used such as fertilizer application can be altered. Third, discharge reduction structure, such as filter strips, grassed waterway, and diversions can be constructed to reduce pollutants discharge to the water body. The total cost of pollution reduction from a farm is composed of two terms: the change in gross income from altering the output vector and implementation costs of discharge reduction structures.

For this model, it is assumed that all abatement activities increase the cost of agricultural production so that farmers would not implement any abatement activities unless they are compensated (cost-share or purchase of nutrient reduction credits by point sources). In a WQT market, a nonpoint source would have the incentive to reduce their pollution discharge level 
through abatement activities $(z) . z=\left(z_{1}, z_{2}, z_{3} \ldots \ldots z_{j}\right)$ denotes a vector of $z$ abatement activities in a farm. The profit for a firm in the adoption of pollution abatement activities is:

$$
\pi_{i}=p y-c_{i}\left(x_{i} z_{j}\right)
$$

The total pollution discharge after implementation of abatement activities is: $r_{j}=r_{j}\left(x_{i}, \mathrm{z}_{\mathrm{j}}\right)$. However, a firm cannot implement any abatement activity more than the land area that the firm own. Thus, the first constraint is:

$$
z_{j} \leq A_{i}
$$

Where $A_{i}$ is the total agricultural land of the $i^{\text {th }}$ firm

Assume that pollution discharges are convex-increasing in inputs (e.g. fertilizer application) and convex-decreasing in abatement activities, so $r_{x}>0, r_{x x}>0, r_{z}<0, r_{z z}>0$. A farmer chooses level of $z_{j}$ so that the pollution discharges are reduced to $r_{j}=r_{j}\left(x, z_{\mathrm{j}}\right)$. Thus, the total pollution reduction from the $\mathrm{i}^{\text {th }}$ firm is equal to $r_{i}\left(x_{i}\right)-r_{j}\left(x, z_{j}\right)$.

In a WQT market, nutrient credit demand from the point sources (i.e. WWTPs) motivates the non-point sources (i.e. farmers) to implement abatement activities (i.e. agricultural BMPs) and generate nutrient reduction credits to supply in a WQT market. In order to participate in the WQT market, farmers need to satisfy certain baseline level of pollution reduction $\left(q_{b}\right)$ specified by the regulatory authority. Thus, the farmer reduces regulated nutrient runoff by implementing BMPs to meet baseline requirements. The nutrient reduction before generate nutrient credit to supply in a WQT market is:

$$
\mathrm{r}_{\mathrm{i}}\left(x_{i}\right)-r_{j}\left(x, \mathrm{z}_{\mathrm{j}}\right) \geq q_{b}
$$

The firm $i$ aims to maximize its profit from the agricultural production.

$$
\operatorname{Max} \widehat{\pi}_{l}\left(x_{i} z_{j}\right)
$$

Subject to: (3.18) and (3.19) 
The constraint (3.19) shows that the amount of nutrient reduction cannot exceed the baseline requirement. This maximization problem can be solved by using the Kuhn-Tucker conditions.

$$
L=\operatorname{Max} \widehat{\pi}_{l}\left(x_{i} z_{j}\right)+\lambda\left(q_{b}-\mathrm{r}_{\mathrm{i}}\left(x_{i}\right)-r_{j}\left(x, \mathrm{z}_{\mathrm{j}}\right)\right)
$$

By differentiating this with respect to $z_{j}$ we get the Kuhn-Tucker conditions for the optimum:

$$
\begin{aligned}
& \frac{\partial \widehat{\pi}_{l}\left(x_{i} z_{j}\right)}{\partial z_{j}}-\lambda \geq 0, \quad z_{j}\left[\widehat{\pi}_{\imath}^{\prime}\left(x_{i} z_{j}\right)-\lambda\right]=0 \\
& \mathrm{r}_{\mathrm{i}}\left(x_{i}\right)-r_{j}\left(x, \mathrm{z}_{\mathrm{j}}\right) \geq q_{b}, \quad \lambda\left[q_{b}-\mathrm{r}_{\mathrm{i}}\left(x_{i}\right)-r_{j}\left(x, \mathrm{z}_{\mathrm{j}}\right)\right]=0 \\
& z_{j} \geq 0 ; \quad \lambda \geq 0
\end{aligned}
$$

The $\lambda$ represents the marginal abatement cost (MAC) of the firm, expressed as $\frac{\partial \widehat{\pi}_{l}\left(x_{i} z_{j}\right)}{\partial z_{j}}$, where $\pi_{i}$ profit from the agricultural production practices based on production costs and revenues. The reduction in the total profit from the implementation of abatement activities represents total cost of abatement for the farmer. This $\lambda$ is positive only when the nutrient reduction constraint (3.19) is binding.

Farmer $i$ can participate in a WQT market after meeting the baseline requirement. Let us assume that it will generate certain amount of credits $\left(q_{s}\right)$ to supply in a WQT market. Thus, the $i^{\text {th }}$ farmer's total nutrient reduction is:

$$
\mathrm{r}_{\mathrm{i}}\left(x_{i}\right)-r_{j}\left(x, \mathrm{z}_{\mathrm{j}}\right) \leq q_{s}+q_{b}
$$

Now, the objective of a firm is assumed to be maximized by gains from production and nutrient credit sales. The decision problem facing a typical farmer is:

$$
\operatorname{Max} \widehat{\pi}_{l}\left(x_{i} z_{j}\right)+\mathrm{p}\left\{\left(\mathrm{r}^{*}(\mathrm{x})-\mathrm{r}_{\mathrm{j}}\left(\mathrm{x}_{i}, \mathrm{z}_{\mathrm{j}}\right)\right)-\mathrm{q}_{\mathrm{b}}\right\}
$$

Subject to: (3.18) and (3.25) 
The constraint (3.19) shows that the amount of total nutrient reduction from the $i^{\text {th }}$ firm cannot exceed baseline requirement plus total supply of credits in the WQT market. The solution for the maximizing problem can be reached by solving following Kuhn-Tucker conditions:

$$
\begin{gathered}
\frac{\partial \hat{\pi}\left(x_{i} z_{j}\right)}{\delta z_{j}}-p \geq 0 \ldots \ldots \\
z_{j}\left[\hat{\pi}^{\prime}\left(x_{i} z_{j}\right)-p\right]=0 \\
z_{j} \geq 0 \ldots \ldots \ldots \ldots \ldots
\end{gathered}
$$

A comparison of equations 3.22 through 3.24 with equations 3.27 through 3.29 shows that $p=\lambda=$ MAC to be a sufficient condition for profit maximization problem. All participating farmers make decisions about how many of nutrient credits they would supply based on their own MAC and market price of nutrient credit. When the price of credit goes up, then the farmer will supply more credits and at the same time controls more pollution. For a farmer (i), the supply function of nutrient credit is $q_{s}^{i}\left(p ; z_{j}\right)$, which is conditional on the abatement activity (i.e. type of BMP implemented) and market price of the nutrient credit. The market level supply curve is obtained by aggregating the supply of all farmers across $\mathrm{i}: \mathrm{S}(p)=\sum_{j} q_{s}^{i}\left(p ; z_{j}\right)$.

In a perfectly competitive WQT market, point and nonpoint sources are involved in nutrient credit trading to the point where marginal costs of both parties are equal. At the equilibrium condition, point sources purchases $Q^{*}$ credits from nonpoint sources and/or point sources at a price of $\mathrm{P}^{*}$ (Figure 3.1). Area under the demand curve and above the price line represents the net market gains (consumer surplus) to point sources reflecting the difference between the potential cost of technology upgrades and the actual cost of nutrient credits at price P*. Similarly, area under the price line and above the supply curve is the net gain (producer 
surplus) to nonpoint sources from the sale of nutrient credits at price $\mathrm{P}^{*}$. The sum of these two areas is equal to total benefits or total cost savings from the WQT program.

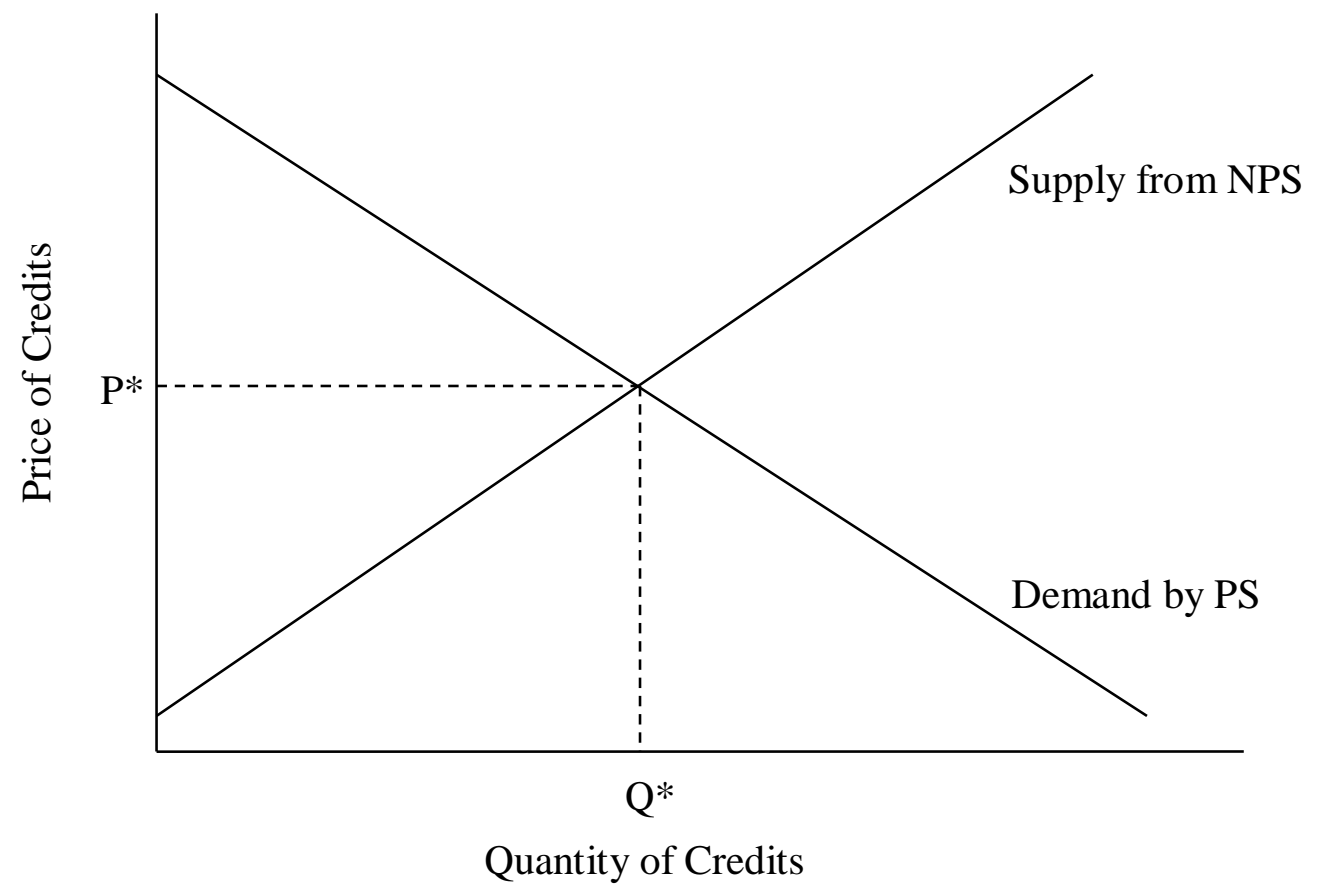

Figure 3.1: Equilibrium Market Price and Quantity in a Perfect Competitive WQT Market

\subsection{SOCIAL OPTIMUM}

The social optimum in the above model involves choosing the optimal values for point source discharge $\left(e^{*}\right)$, agricultural input $\left(x^{*}\right)$, and abatement activity $\left(z^{*}\right)$. The benefit function for point and nonpoint sources can be represented by $\pi_{1}(e)$ and $\pi_{2}(x, z)$, respectively. The pollution discharges from both sources causes water quality damages, defined as $D(e, r)$, which indicates that increase in emission or runoff will increase the economic costs of pollution. Following the models developed by Heberling et al. (2010), the total social welfare $(W)$ can be expressed as:

$$
W(e, x, z)=\pi_{1}(e)+\pi_{2}(x, z)-D(e, r)
$$


Where, $r=r(x, z)$, farmer's profit as a function of runoff can be represented by $\pi_{2}(r)$

Differentiation of equation (3.30) with respect to $e, x$, and $z$ will gives:

$$
\begin{gathered}
\frac{\partial W}{\partial e}=\pi_{e 1}-D_{e}=0 \\
\frac{\partial W}{\partial x}=\pi_{x 2}-D_{r}=0 \\
\frac{\partial W}{\partial z}=\pi_{z 2}-D_{r}=0
\end{gathered}
$$

Dividing equation (3.31) by (3.32) gives:

$$
\frac{\pi_{e 1}}{\pi_{x 2}}=\frac{D_{e}}{D_{r}}
$$

Where, $\pi_{x 2}=\pi_{r 2} . \quad \pi_{2}$ is the farmer's marginal profit as a function of runoff. Equation (3.34) represents the optimal condition where the ratio of marginal benefit of point source's emission and agricultural runoff should be equal to the ratio of the marginal costs of damages from point and nonpoint sources. Similarly, dividing equation (3.31) by (3.33) gives:

$$
\frac{\pi_{e 1}}{\pi_{z 2}}=\frac{D_{e}}{D_{r}}
$$

This condition indicates the optimal condition for the application of abatement activities in the agricultural land. The optimal condition for the abatement activities is represented by the ratio of marginal benefit of point source's emission and abatement activities equal to the ratio of the marginal costs of damages.

Equations (3.34) and (3.35) provide an important implication for the application of agricultural inputs (e.g. fertilizers) and abatement alternative (e.g. implementation of cover crop). Using equation (3.34) and (3.35), we can get $\pi_{x 2}=\pi_{z 2}$, which indicates that farmers can tradeoff between agricultural input and abatement activity until the point where marginal benefit of agricultural input is equal to the marginal benefit of abatement activity. Equations (3.34), (3.35), and equality of marginal benefit of agricultural input and marginal benefit of abatement 
activity are necessary conditions to maximize social welfare. Solutions of this problem gives $e^{*}$, $x^{*}$, and $z^{*}$ that maximizes the economic gains.

\subsection{SINGLE AND COMBINED NUTRIENTS MARKET}

The theoretical models in section 3.5 and 3.6 represent a single nutrient, either TN or TP, credit trading in a WQT market. Some abatement technologies, e.g. biological nutrients removal (BNR), can reduce both nutrients simultaneously and can save operational costs (Jayanagagam 2005). Under these technologies, the total cost of nutrient removal needs to be allocated between the cost of TP reduction and cost of TN reduction. In this case, this allocation was based on the ratio of TN and TP inflow to the treatment plant. In a combined $\mathrm{P}$ and $\mathrm{N}$ WQT market, this simultaneous nutrient reduction will affect the per unit price of TP credit and TN credit.

Similar to a point source's nutrient reduction, nonpoint sources can reduce TP and TN simultaneously from the BMP within same cost of implementation. For cost allocation, the total cost of nutrients removal can be divided among the cost of TN reduction and the cost of TP reduction based on the ratio of TN and TP reduction from the BMP (CTIC 2011). In a combined TN and TP WQT market, a farmer can supply both nutrient credits together that will affect the per unit price of TN credit and TP credit.

In the combined nutrient market, all WWTPs are required to reduce TN in addition of TP reduction. While this requirement increases the total cost of compliance to meet multiple standards, multiple nutrients reduction from the agricultural non-point sources significantly reduces per unit costs for both $\mathrm{TN}$ and TP reduction. The operational costs for combined nutrient reduction and single nutrient reduction from the implementation of BMPs in the agricultural lands remain same. Therefore, WWTPs can purchase TP and TN credits at lower cost in a combined nutrients market than the total cost of compliance and the total cost of TP credits 
purchase in the single nutrient market. Figures 3.2 and 3.3 present the demand and supply TP and TN credits in a combined nutrients market. The goal of each WWTP is to reduce TP. A market for TN credits was included to drive down the equilibrium price of TP credits. Per unit cost of TP reduction from WWTPs and credit generation from the agricultural sources both decrease in the combined nutrient market thereby shifting downward both the demand and supply curves in a combined nutrient market.

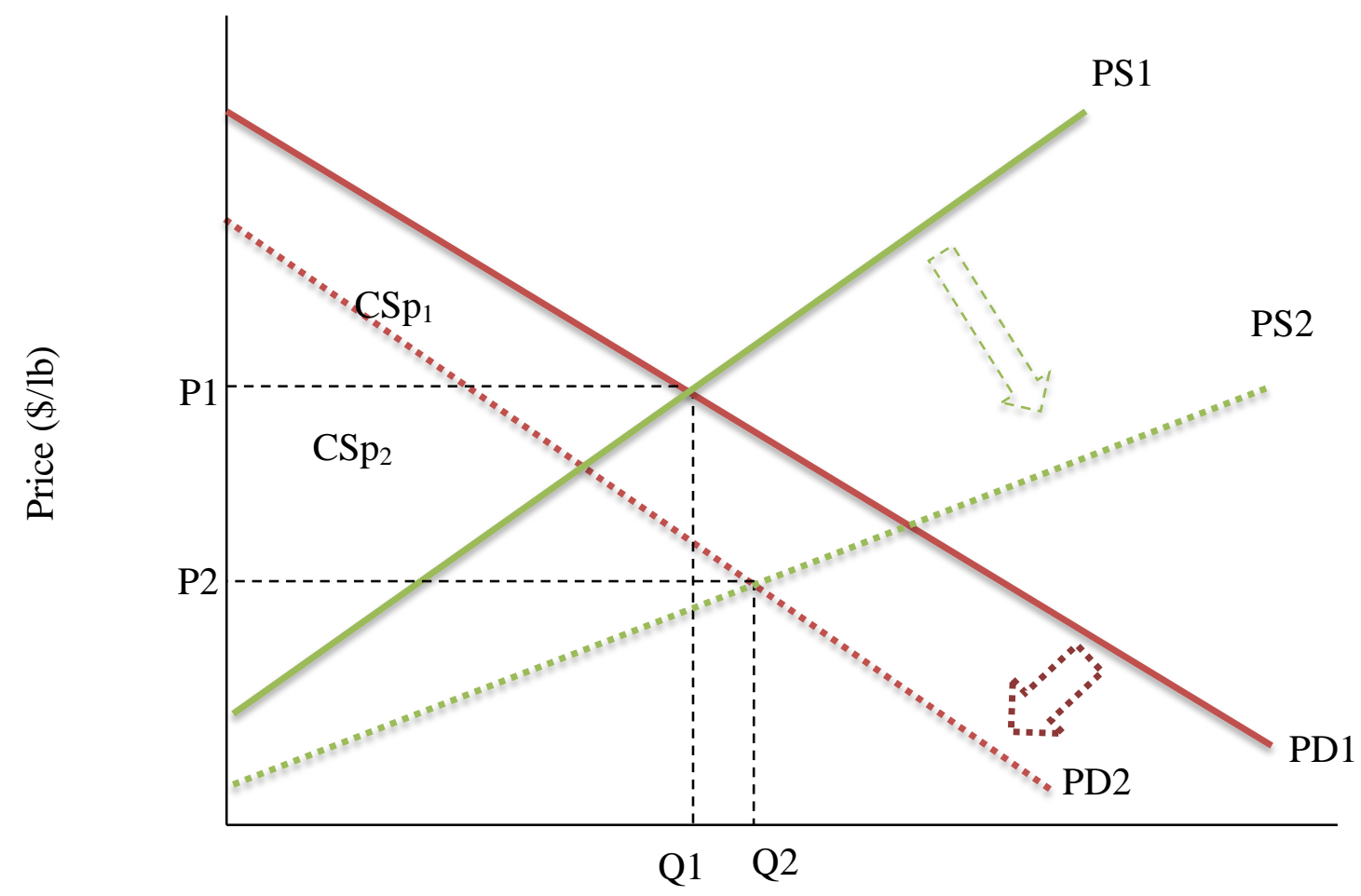

Phosphorus (lb)

Figure 3.2: Demand for and Supply of TP Credits in a TP Nutrients Market under a Combined Market where WWTP can purchase TN Credits 


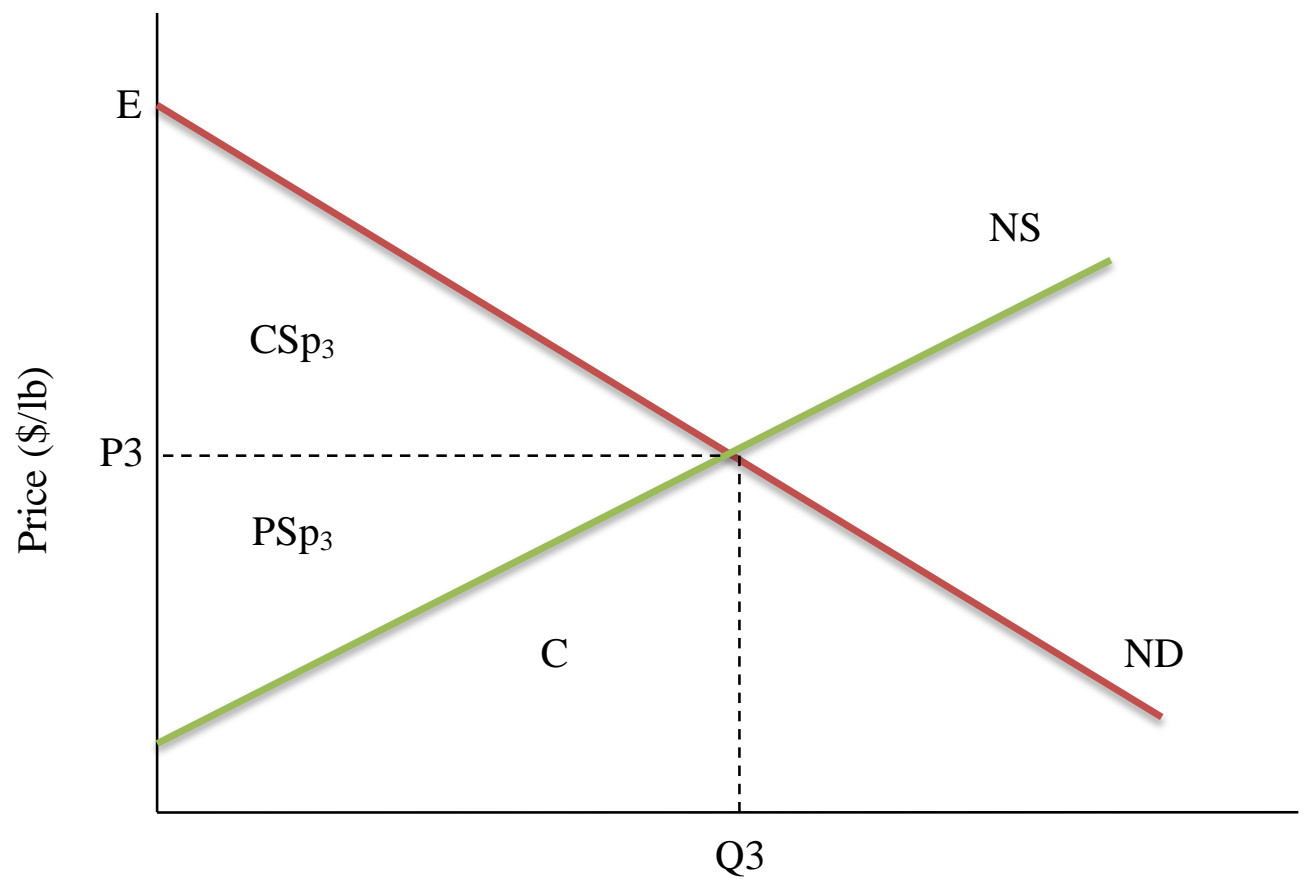

Nitrogen (lb)

Figure 3.3: Demand for and Supply of N Credits when a WWTP Considers N Credits Purchase From the perspective of WWTPs, it makes economic sense to include a TN market with TP market when:

$$
C S_{P 2}-C \geq C S_{P 1}
$$

Where, $C S_{P 1}=$ Consumer Surplus at PS1 supply in a single market, $C S_{P 2}=$ Consumer Surplus at PS2 supply in a combined market, $\mathrm{C}=$ cost to farmers to generate $\mathrm{N}$ credits, $\mathrm{P} 1=$ Equilibrium price at PS1 supply of P, P2 = Equilibrium price at PS2 supply of P, P3 = Equilibrium price at NS supply of $\mathrm{N}, \mathrm{Q} 1$ = Equilibrium quantity at PS1 supply of $\mathrm{P}$ and PD demand, $\mathrm{Q} 2=$ Equilibrium quantity at PS2 supply of P and PD demand, and Q3 = Equilibrium quantity at NS supply of N and ND demand.

The feasibility condition to consider the combined nutrient market is:

$$
\mathrm{CSp}_{2}+\mathrm{PSp}_{2}-\mathrm{C}>\mathrm{CSp}_{1}+\mathrm{PSp}_{1}
$$


Where, $C S_{P 2}=$ Consumer Surplus at PS2 supply in a combined market, $P S_{P 2}=$ Producer Surplus at PS2 supply in a combined market, $C S_{P 1}=$ Consumer Surplus at PS1 supply in a single market, $P S_{P 1}=$ Producer Surplus at PS1 supply in a single market, $\mathrm{C}=$ cost to farmers to generate $\mathrm{N}$ credits

Equation 3.67 indicates that a combined nutrients market would be feasible when the total economic gain (CS + PS) in a combined market is greater than the total economic gain (CS + PS) in a single market minus total cost of farmer to generate nitrogen credits.

\subsection{NUTRIENT LOADINGS MODEL}

Measurement of pollutants discharge from various sources to river and stream is very costly and sometimes almost infeasible. Water quality modeling techniques can serve as an alternative to the monitoring of river and stream water quality. Water quality models are used to estimate current pollution load from the different sources in a watershed. Models can predict the amount of pollution reductions from the implementation of BMPs in agricultural lands and upgrade of point source's treatment systems. Water quality modeling assists in estimating amount of tradable pollutants (supply of credits) from the non-point sources in different locations within a watershed. These estimates support feasibility analysis of water quality trading as well as development of a water quality trading program in a watershed.

The MapShed hydrologic simulation program was used to support the water quality trading feasibility analysis in the Greenbrier River watershed. The modeling process involved creating GIS based data compatible for the MapShed. The water quality modeling in the MapShed is grid based comprising of stream network, digital elevation model (DEM), land use/land cover grids, and soil map. The model also requires temperature and precipitation data. The MapShed model simulates a daily stream flow and monthly nutrients (nitrogen and 
phosphorus) and sediment loads from various sources (e.g. agricultural, forested, and developed land) in a watershed.

The Generalized Watershed Loading Function (GWLF) in the MapShed model simulates surface runoff using the soil conservation service- curve number (SCS-CN) approach with daily weather data inputs. It uses a universal soil loss equation (USLE) algorithm and KLSCP (soil loss/erosion (K), the length/slope factor (LS), the vegetation cover factor (C), and the conservation practices factor $(\mathrm{P})$ ) values for each source to estimate erosion and sediment yield from different sources in a watershed. Total nitrogen and phosphorus losses from the various sources are estimated by applying dissolved $\mathrm{N}$ and $\mathrm{P}$ coefficients to surface runoff and a sediment coefficient to the yield portion for each source. Within MapShed, each standard land cover class has a unique loading coefficient for $\mathrm{N}$ and $\mathrm{P}$ based on published literature values (Evans and Corradini 2012). Similar to land cover class, specific N and P reduction coefficients associated with each BMP are used to estimate the potential total $\mathrm{N}$ and $\mathrm{P}$ reductions from the use of BMPs. The water quality model used in this study analyzes current pollutants loads and potential reduction from the implementation of agricultural BMPs in the crop and pasture/grasslands in the watershed.

The MapShed water quality model simply aggregates the loads from each source area into a watershed total without considering spatial distribution. For sub-surface loading, the model acts as a lumped parameter model using a water balance approach. The detail description of water quality estimation mechanisms are discussed in the MapShed manual. 


\section{CHAPTER 4: STUDY AREA FOR WQT FEASIBILITY ANALYSIS}

\subsection{GREENBRIER RIVER WATERSHED}

The Greenbrier River Watershed (GRW) is located in southeastern West Virginia which covers a large area of Pocahontas and Greenbrier Counties and some area of Monroe and Summers Counties (Figure 4.1). The Greenbrier River is a major tributary of Kanawha River which drains into Ohio River from the west side of West Virginia. The waters of the Greenbrier River ultimately flow into the Ohio and Mississippi Rivers and eventually to the Gulf of Mexico.

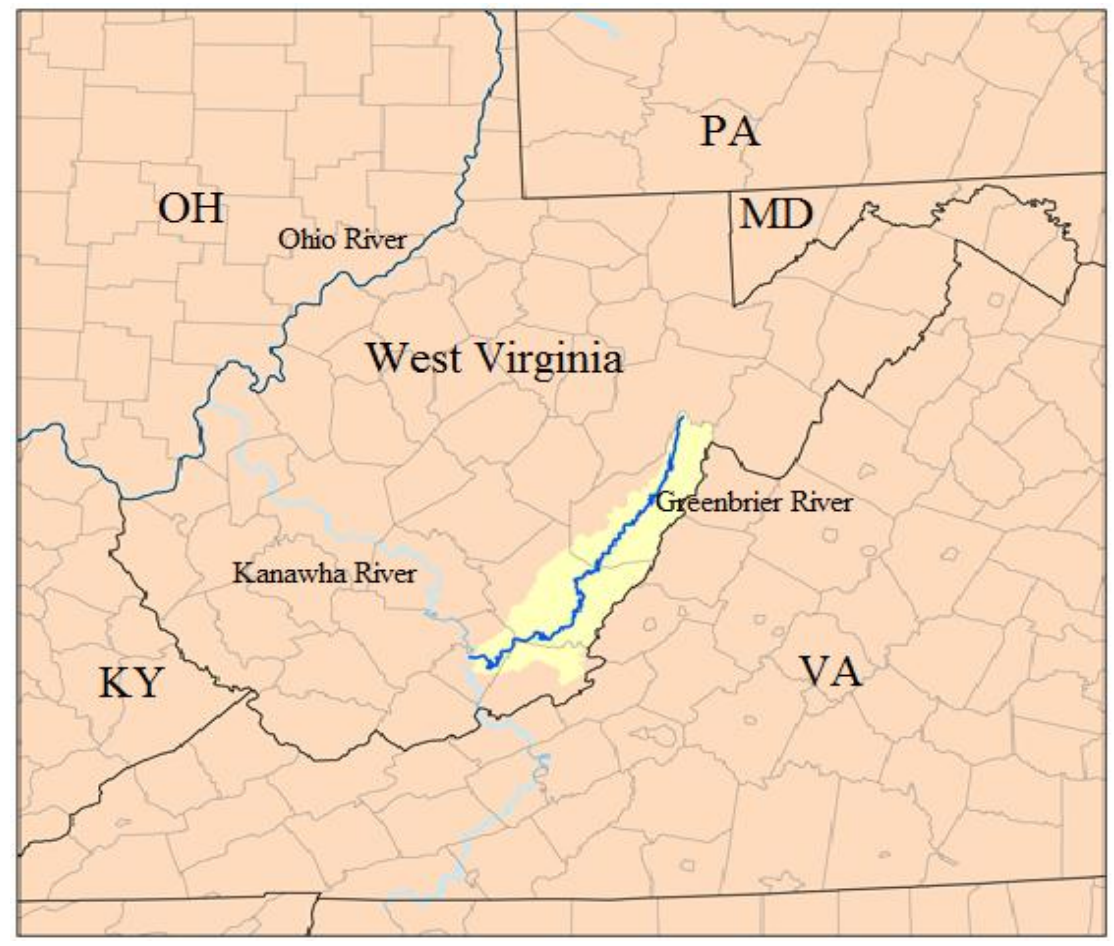

Figure 4.1: Locality Map of Greenbrier River Watershed

The Greenbrier River emerges in the Pocahontas County. Over half of area of this County is covered by state forest, state parks, and national forests. Greenbrier County is known for its karst topography. Karst is an area of limestone terrain characterized by sinks, ravines, and underground streams. This area creates rapid and direct connection between surface and ground 
water as a result pollution discharge to the rivers and streams percolate to the ground water very rapidly. The pollutants also travel far from the point of origin in a very short time (Boyer 2005).

Greenbrier County is known for its recreational opportunities, rich farm lands, and large commercial caves. This river flows through Monroe County and joins at the New River in the town of Hinton, Summers County. Monroe County is well known for agriculture especially apple orchards and cattle and dairy farm, and trout waters. Summers County contains the least amount of karst topography of all the watershed Counties. This watershed is home to over 38,000 residents and drains an area of over 1640 square miles. Cities and towns in the watershed include Durbin, Green Bank, Marlinton, Hillsboro, Frankford, Lewisburg, Alderson, Hilton, and White Sulphur Springs. The land use land cover classification for Greenbrier River watershed is shown on Figure 4.2.

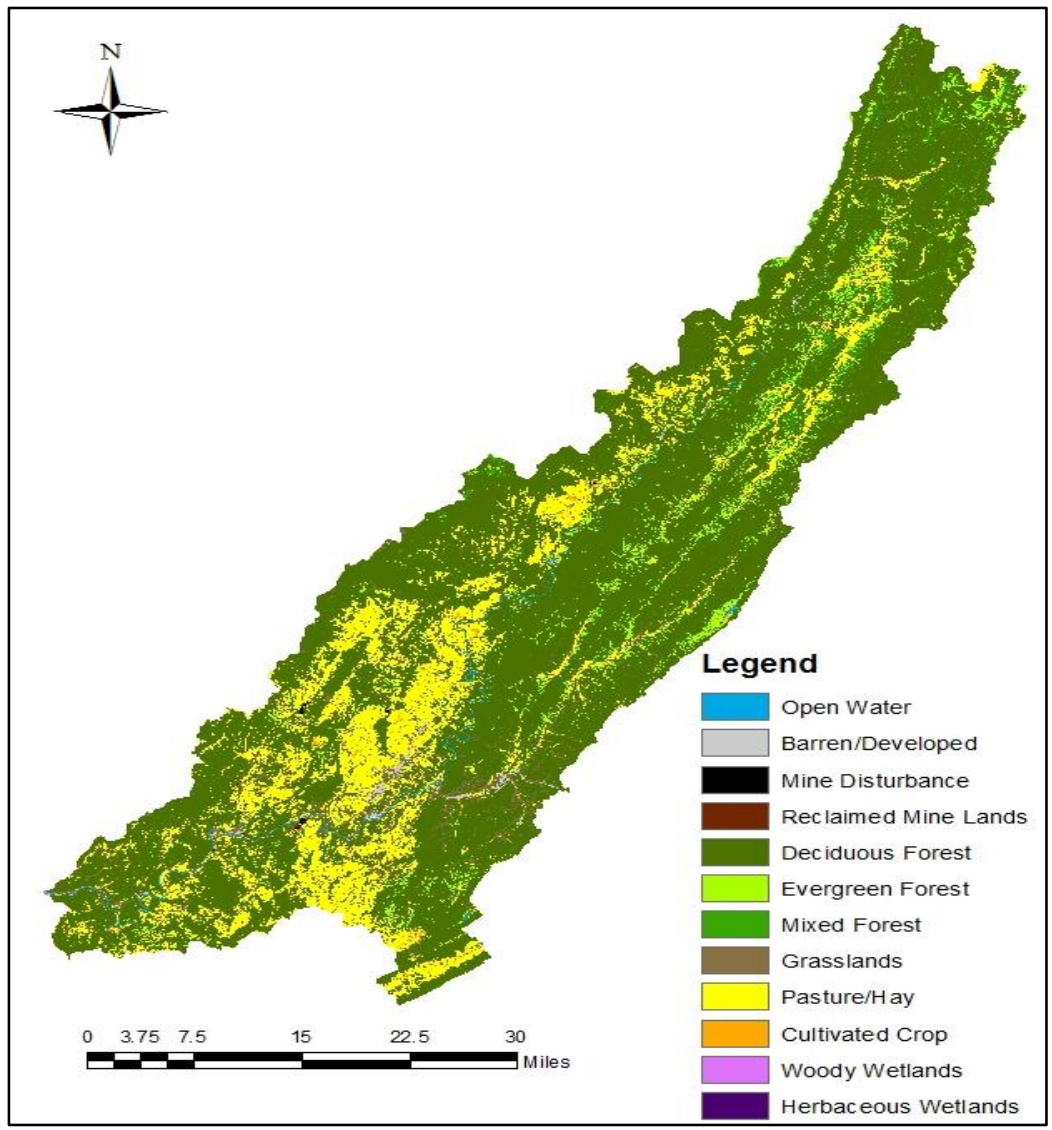

Figure 4.2: Land Use and Land Cover in the Greenbrier River Basin 
The Greenbrier River Watershed is dominated by forest land uses (77.9\%), with some karst landscape (10.1\%), grassland (6.2\%), pasture (4.0\%) land, and other (1.8\%) uses.

This research is focused on the entire Greenbrier River watershed, with fifteen subwatersheds: Upper Greenbrier River, Deer Creek, Sitlington Creek, Stony Creek, Knapp Creek, Marling Creek, Anthony Creek, Spring Creek, Howard Creek, Second Creek, and Muddy Creek (Figure 4.3).

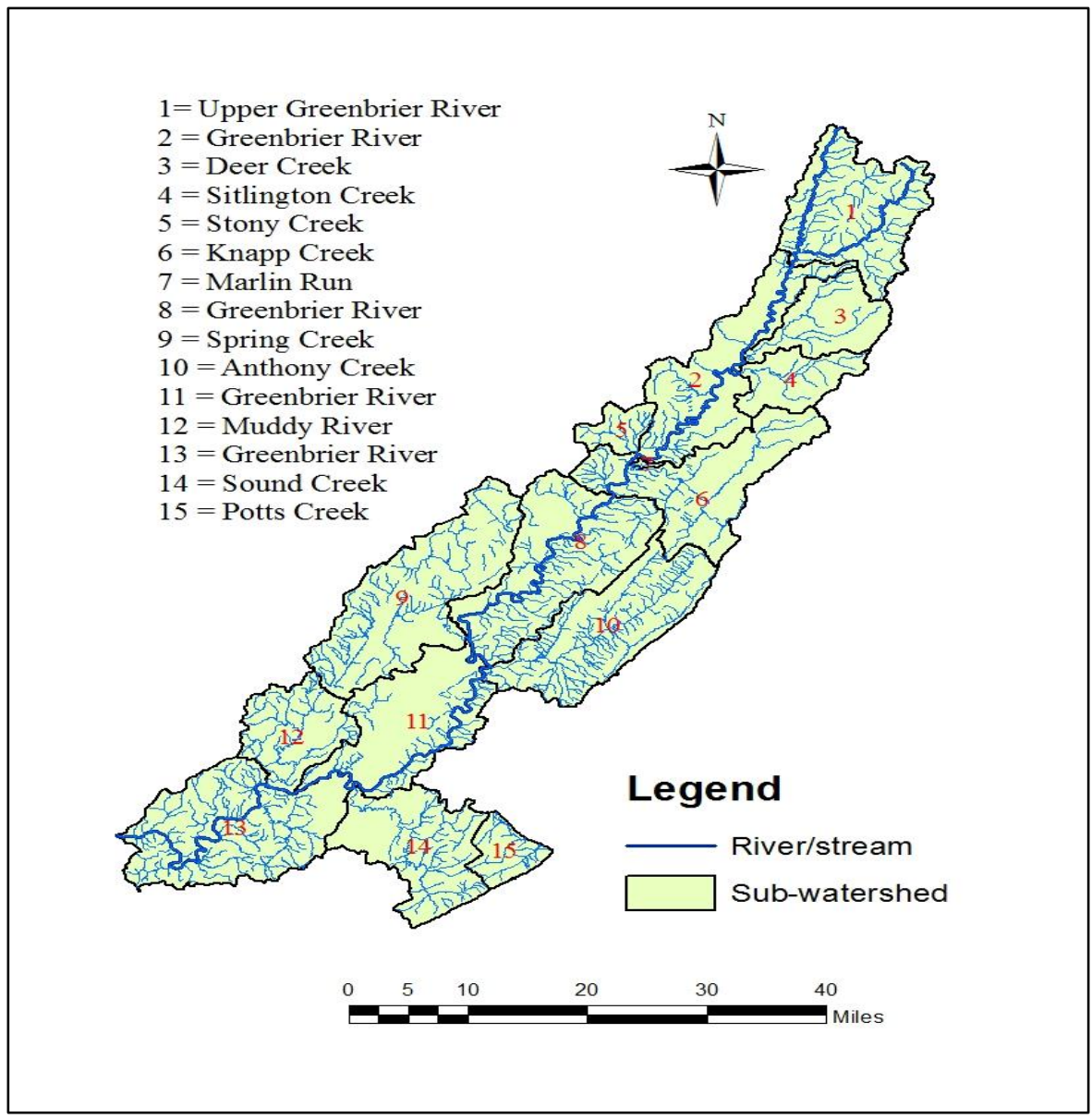

Figure 4.3: Rivers and Streams in the Greenbrier River Watershed

Figure 4.4 presents location of WWTPs in the Greenbrier River watershed. WVDEP has recognized six wastewater treatment plants (Alderson, Ronceverte, Greenbrier PSD No.1, White Sulfur Spring, Hillsboro, and Marlinton) in the Greenbrier River watershed as significant nutrient dischargers into the Greenbrier River (USEPA 2010). 


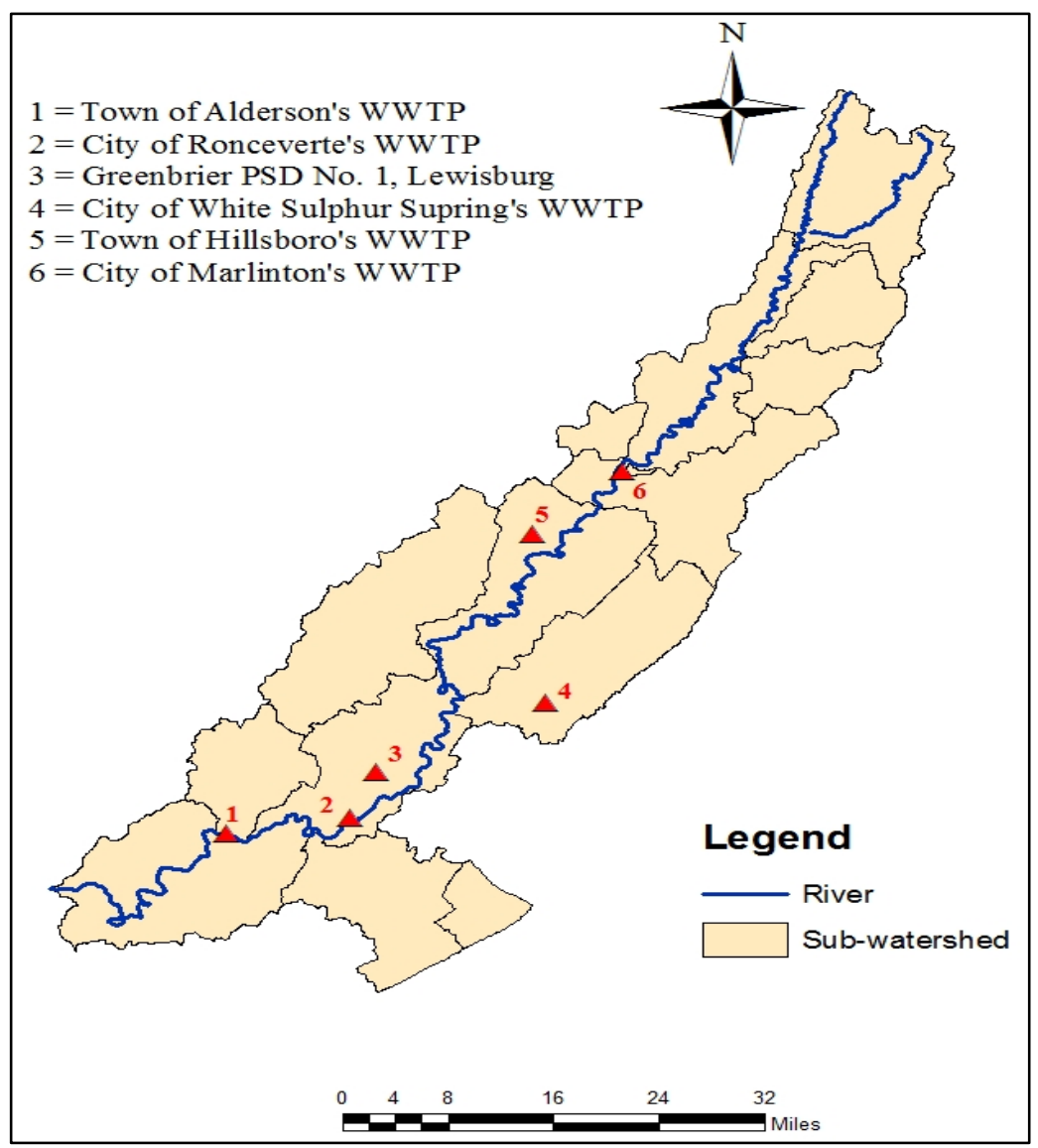

Figure 4.4: Location of WWTPs in the Greenbrier River Basin

\subsection{WATER QUALITY MANAGEMENT IN GREENBRIER RIVER WATERSHED}

The high level of phosphorus in the Greenbrier River is one of the major water quality problems in the Greenbrier River watershed (Summers 2008). Many rivers and streams within the watershed are impaired from the growth of benthic macro-invertebrates (biological impairment) and fecal coliform bacteria (WVDEP 2011). Most streams listed with biological impairments have an unknown pollutant (WVDEP 2011). WVDEP lists failing septic systems, runoff from agricultural and residential lands, wastewater treatment plant discharges and combined sewage overflows are primary sources of surface water pollution in the watershed (WVDEP 2011). This high level of impairment affects the public water supply and recreational uses on the Greenbrier River. 
The WCMS model estimations by Dr. Michael Strager for nitrogen and phosphorus discharges from agricultural sources indicate that the marginal contributions of nitrogen and phosphorus from the agricultural land are high in wolf creek, second creek, sinking creek, and muddy creek sub-watersheds in the Greenbrier River watershed (Appendix A). These subwatersheds include a large area of crop and grass/pasture lands and most of significant point source dischargers (i.e. WWTPs). The MapShed model used for this study also estimates a high level of nitrogen and phosphorus discharges from the agricultural sources in these subwatersheds.

The Clean Water Act (CWA) requires a Total Maximum Daily Load (TMDL) to be developed for those water bodies identified as impaired by a state where technology-based and other controls do not provide attainment of water quality standards (USEPA 1997). TMDLs were completed in 2008 for the 39 impaired streams listed on the 2006 303(d) impaired list for fecal coliform bacteria in the Greenbrier River watershed. The WVDEP is currently developing nutrient criteria to maintain water quality standards in the Greenbrier River and its tributaries (WVDEP 2012).

The WVDEPs proposed plan for point source nutrient discharge reduction is to upgrade WWTPs along the Greenbrier River. The WV Chesapeake Bay Bill (SB245) passed in 2011 legislative session will grant funds to three communities along the lower Greenbrier River for upgrading their wastewater treatment plants to remove excess phosphorus and other nutrients (Hemmelgarn 2011). Wastewater treatment plants at White Sulfur Springs, Ronceverte, and Alderson qualify for the funds with a pumping capacity of at least 400,000 gallons per day (WVDEP 2011). Funds for both Hillsboro and Marlinton sewage treatment plants are still being sought. 


\section{CHAPTER 5: RESEARCH METHODOLOGY}

\subsection{INTRODUCTION}

This chapter describes the methods and techniques used for the water quality modeling, nutrient credits demand and supply estimations, and methods of water quality trading feasibility analysis. The first section of the chapter discusses data collection from farm best management practices in the Greenbrier County, WV. The second section describes the collection and preparation of GIS data layers for water quality modeling, data integration and model building, and model validation and calibration for the estimation of nutrient load discharges in the watershed. Methods of potential nutrient credit supply and the cost of nutrient credit estimations are discussed in section three. The fourth section presents the method of nutrient credit demand estimation and cost of WWTPs for nutrients reduction. The final section of this chapter discusses the method of evaluating the impact of existing levels BMPs in the potential WQT market.

\subsection{SURVEY OF AGRICULTURAL BEST MANAGEMENT PRACTICES}

In the Greenbrier River watershed, large areas of pasture, hay, grass, and crop lands are concentrated in the Greenbrier County. This county was selected to account for the diversified farm practices within the Greenbrier River watershed. Farmers in the Greenbrier County were surveyed between May 2011 and August 2011 to identify and estimate the current agricultural best management practices implemented since January 2000. The survey included four sections of questions in the following order: a) general information about farm operation; b) best management practices; c) farmer's concern on water quality, interest in water quality trading, economic and demographic questions; and d) information about current land manager if land was leased to another farmer. 
Section 'a' identified how crop and pasture lands were managed (own managed, leased, idle or other), the major farm operation (e.g. livestock, crop, hay, and dairy), and percentage contribution of farming to annual household income. Section ' $b$ ' focused on current BMPs implemented at the owner's expense and with NRCS cost share assistance, areas of BMPs implemented at the owner's cost and with NRCS cost share, and interest in implementing BMPs in the crop and pasture lands. Section 'c' asked concerns about the river and stream water quality, knowledge of nutrient trading program, interest in learning about water quality trading, and socio-economic and demographic characteristics (i.e. age, education, and income). The survey questionnaire was constructed based on the review of previous BMPs surveys and pretests. In the survey, farmers were asked which of the eight BMPs in the crop land and nine BMPs in the pasture land they had adopted. Farmers were also asked to mention any BMPs which were not included in the BMP list but they had adopted since January 2000. Copies of survey questions for crop and pasture land owners are presented in the Appendix D and Appendix E respectively.

The survey population was agricultural land owners in Greenbrier County. Crop and pasture land owners mailing address, parcel ID, type of land uses, and parcel size were obtained from the Greenbrier County Assessor's office in Lewisburg, WV. All land owners who owned a pasture parcel $\geq 50$ acres and/or crop parcel $\geq 10$ acres were included in the survey. The mailing list included 349 crop land owners and 194 pasture land owner. Two survey instruments, one for pasture land and another for crop land were sent to agricultural land owners. The first mailing was followed by a postcard reminder to all who received the survey. One month later, a second copy of the survey was sent to all non-responders. Total survey responses from both mailings 
were 178: 112 from crop land owners (33\%) and 66 from pasture land owners (35\%). The overall survey response was 34 percent.

\subsection{WATER QUALITY MODELING}

The MapShed program was selected for its simplicity in model construction and various advantages over other water quality models. It does not require highly detailed datasets and is very flexible to allow updates and calibrations. Moreover, it offers the following specific features that were useful for this research: i) it estimates monthly and yearly total nitrogen and phosphorus discharge from various land uses (e.g. crop, pasture/hay, grassland, and barren land), ii) the model allows for simulation of various agricultural BMPs scenarios to estimate pollution loads reductions, and iii) it has the ability to simulate pollutant loads from multiple subwatersheds within a larger watershed.

\subsubsection{GIS DATA FOR WATER QUALITY MODELING IN THE MAPSHED}

Although MapShed comes with a default dataset, the user has to generate GIS data for a specific watershed area. Table 5.1 presents a list of GIS data layers prepared for MapShed watershed modeling program on the Greenbrier River watershed.

Table 5.1: Overview of GIS data layers prepared for MapShed

\begin{tabular}{lc}
\hline File Name & Description \\
\hline Shape Files & \\
Watershed Basin & Basin boundary used for modeling (polygons) \\
Streams & Map of stream network (lines) \\
Soils & Soil characteristics data (polygon) \\
Point sources & Point source discharge locations (points) \\
Weather stations & Weather station locations (points) \\
Grid Files & Map of land use/cover classes \\
Land use/cover & Digital Elevation Model (DEM) file \\
Elevation & \\
\hline
\end{tabular}

A watershed boundary shapefile for the Greenbrier River watershed was clipped from the West Virginia watershed boundary shapefile obtained from WV GIS technical center 
(WVGISTC 2012). This watershed includes 14 sub-watersheds in eleven digits hydrologic unit size range from 40,000 to 250,000 acres. The sub-watersheds of the Greenbrier River watershed are shown on Figure 5.1. Nutrient loadings from each sub-watershed are simulated at the mouth of the watershed. The estimates of load reduction from the implementation of agricultural BMPs were also evaluated at the mouth of each sub-watershed.

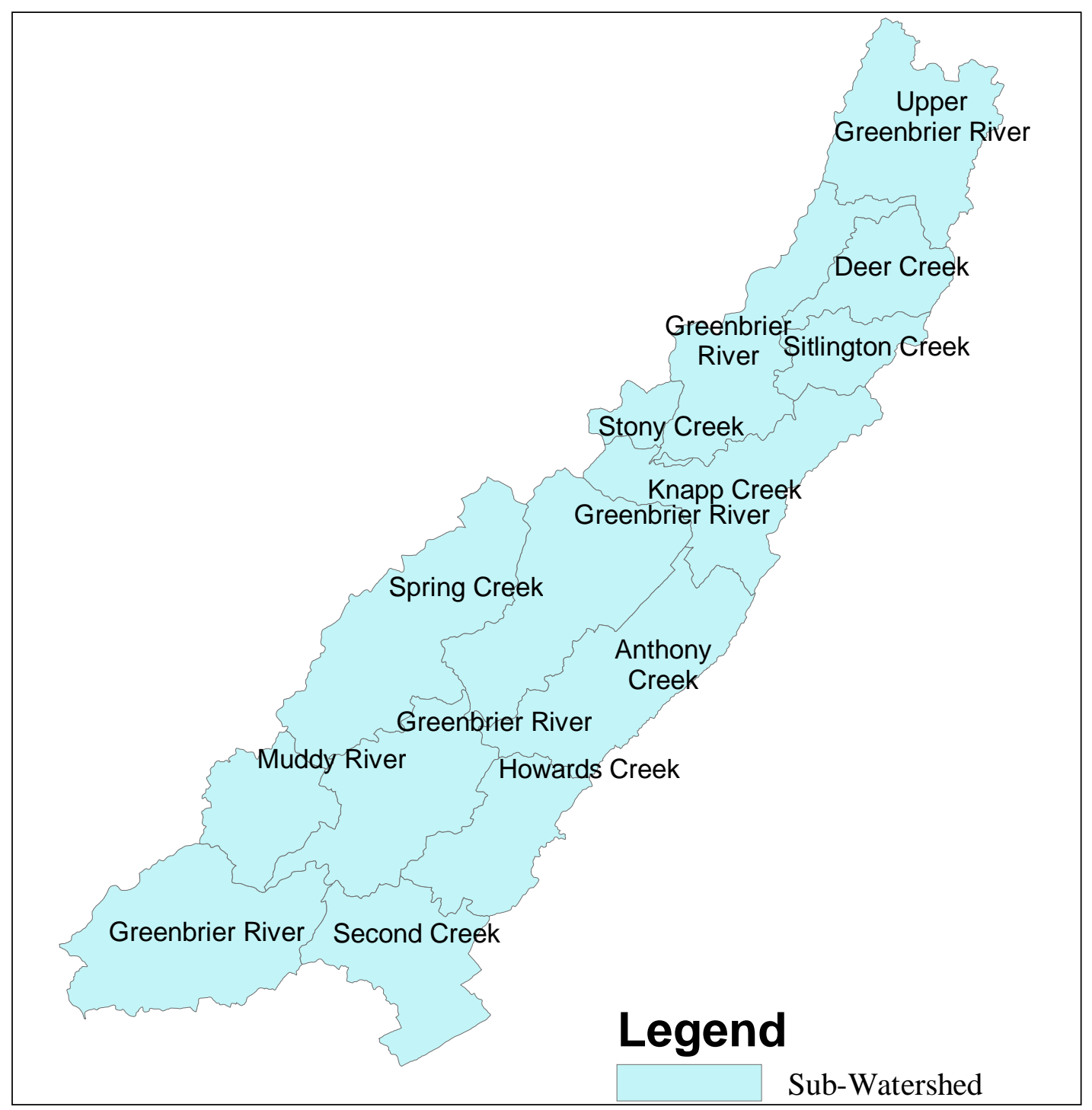

Figure 5.1: Sub-Watersheds of Greenbrier River Watershed

Land use/land cover data (grid file) for the Greenbrier River watershed were obtained from Natural Resource Analysis Center, WVU. Twelve land use classes were distinguished in 
the land use classification: open water, barren/developed, mine disturbance, reclaimed mine lands, deciduous forest, evergreen forest, mixed forest, grasslands, pasture/hay, cultivated crop, woody wetlands, and herbaceous wetlands. These land use classes were reclassified in ArcGIS map to match the land use categories used in the MapShed. Since MapShed does not include grassland category in its land use class, pasture/hay and grassland were included in a single group. Mine disturbance and reclaimed mine land classes were included to the disturbed land class of the MapShed.

The Greenbrier River watershed is dominated by forest land uses (77.9\%), with some karst landscape $(10.1 \%)$, grassland $(6.2 \%)$, pasture $(4.0 \%)$ land, and other $(1.8 \%)$ uses. The land use land cover classification for Greenbrier River watershed is shown on Figure 5.2

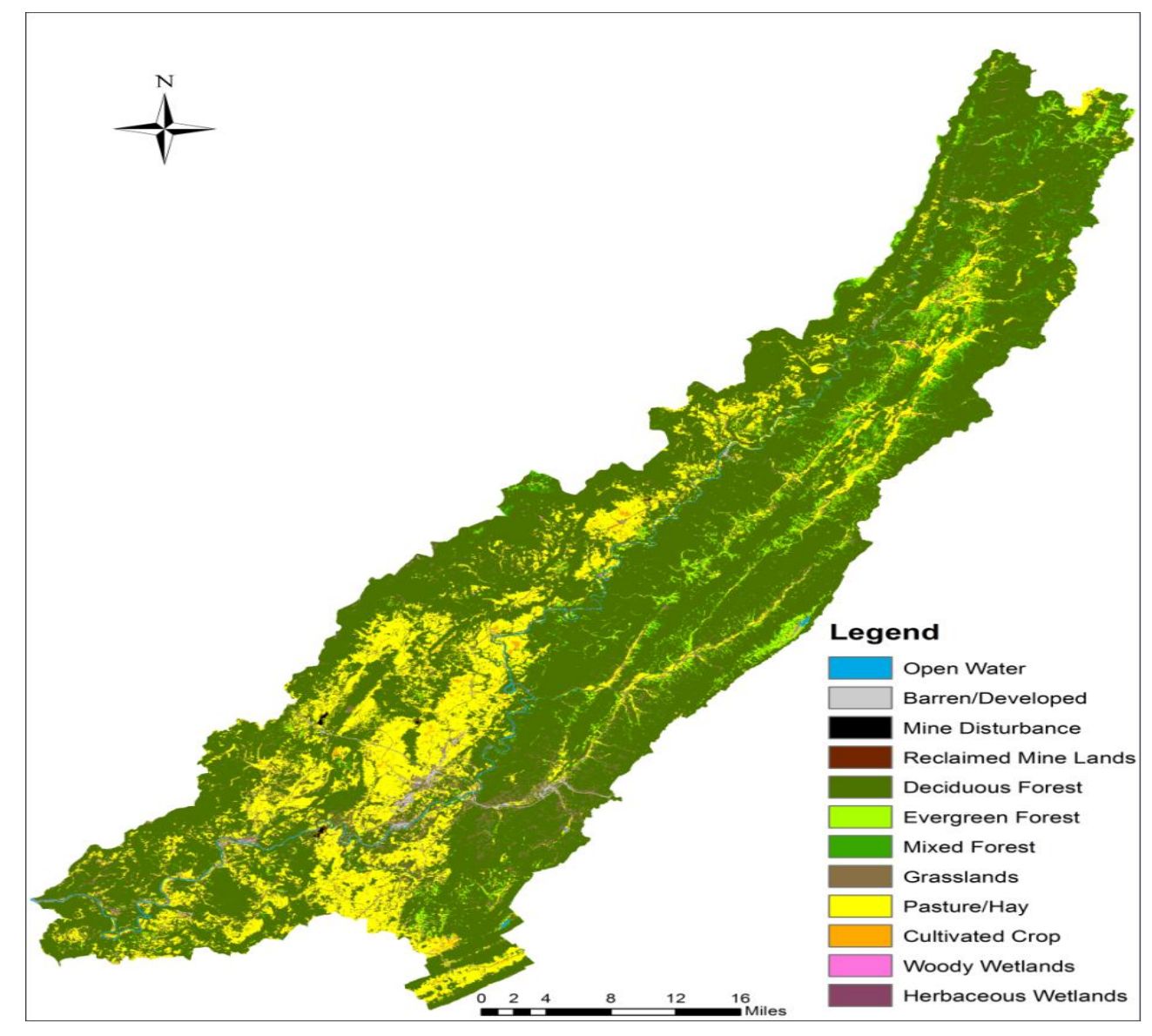

Figure 5.2: Land Use and Land Cover in the Greenbrier River Watershed 
The MapShed uses surface elevation (DEM) layer to calculate land slope related data for runoff estimation. Evans and Corradini (2012) recommend higher resolution grid cell data (20-50 meters) for good model results. A DEM layer (30 meters) for WV was obtained from WV GIS technical center (WVGISTC 2012).

The stream layer contains stream segments for the Greenbrier River watershed (Figure 5.3). These features were derived from the existing National Hydrography Datasets (USGS 1:24000-scale data sets) available from the US Geological Survey. MapShed only supports single line stream features for calculations within MapShed. Thus, polyline stream features in the National Hydrography Dataset were converted to single line.

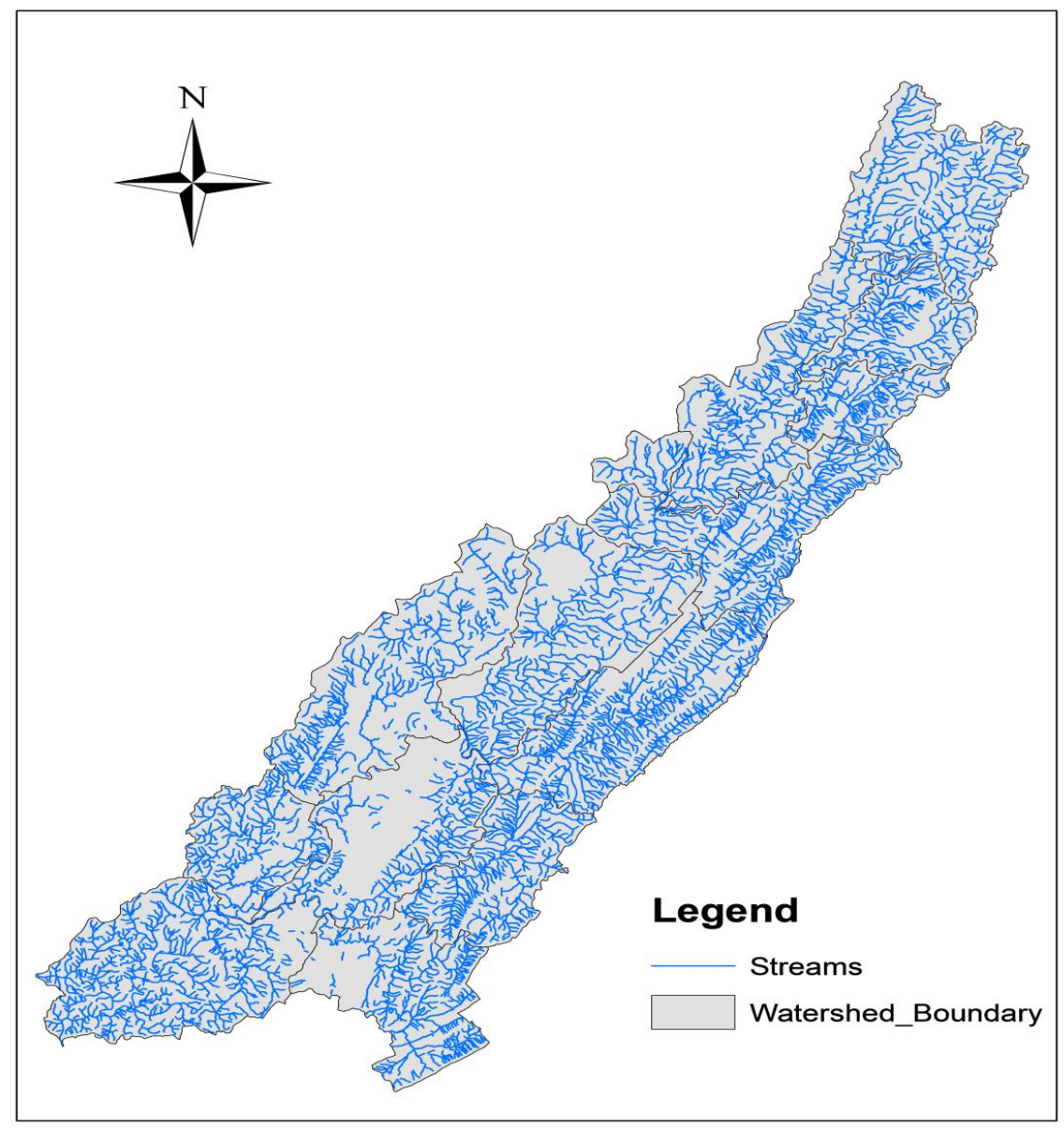

Figure 5.3: Streams Network in the Greenbrier River Watershed 
Digital soil layer and associated data were obtained from the Geospatial Data Gateway of USDA-NRCS. This layer contains the following four important characteristics of soil: i) available water holding capacity (typical range of 2-20 com), ii) soil erodibility (K) factor (typical range of $0.1-0.5$ ), iii) dominant hydrologic soil group (values of $\mathrm{A}, \mathrm{B}, \mathrm{C}$, or D), and iv) organic matter content (typical range of $1.0-6.0$ ). A GIS layer for point source (WWTPs) was created to identify the locations of point sources discharges within the watershed. There are seven NPDES permitted significant dischargers in the Greenbrier River watershed. Names and locations of each point source in the Greenbrier River watershed are shown on Figure 5.4.

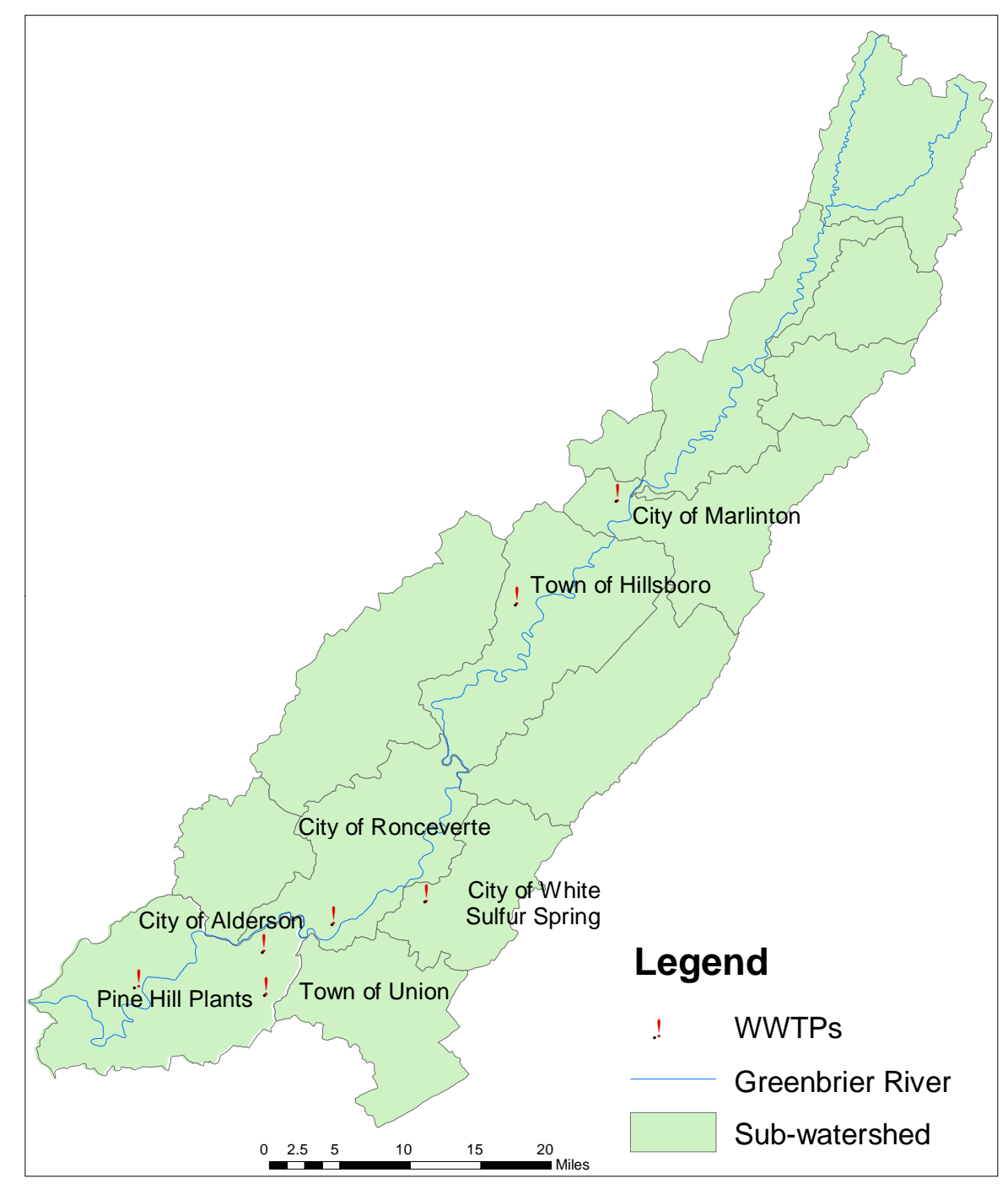

Figure 5.4: Location of the Significant Point Sources in the Greenbrier River Watershed 
All point sources are linked with associated Table which contains information of design flow (MGD), average nutrient concentration (mg/l) in the discharge, and average amount of daily discharge (lb/day). This information was obtained from the EPA's online Discharge Monitoring Report (DMR) for each point source in the Greenbrier River watershed (USEPA 2010).

The MapShed model requires a GIS layer of weather stations located in the watershed. Temperature and precipitation data were collected from the Lewisburg weather station of the Greenbrier County, WV. A GIS layer for the Lewisburg weather station was created to include in the MapShed model. This station in the GIS layer is linked to an excel file containing daily temperature (max and $\min )$ and precipitation data. Daily temperature and precipitation data for Lewisburg station were collected from the online data source of US National Climatic Data Center. Data includes daily temperature and precipitation from January 1990 to December 2011 (21 years of data). The MapShed model determines mean daily temperatures by averaging the daily minimum and maximum temperatures.

\subsubsection{INPUT DATA FOR WATER QUALITY MODELING IN THE MAPSHED}

The MapShed model requires three separate input files: weather.dat, transport.dat, and nutrient.dat. These three files provide the model with the necessary input data for land use, hydrology, erosion and sediment, nutrient concentrations in runoff, and daily temperature and precipitation data. They also provide complete descriptions of the land uses, land cover, soils, topography, sources of discharges, and other relevant information for watershed modeling.

The Weather.dat input file contains daily average temperature and total precipitation values for each year simulated. The transport.dat file includes watershed size, land use and cover, and soil map including curve numbers, erosivity coefficient, daylight hours, initial storage, recession coefficient, etc. The nutrient.dat file specifies the various loading parameters 
for the different sources such as number of septic systems, urban source area accumulation rates, manure concentrations, etc. This study assigns all input parameters based on available data for the watershed and default parameters suggested in the MapShed User's Manual (Haith et al. 1992, Evans and Corradini 2012). Defaults are normally used for many parameters due to the lack of watershed level data.

Transport.dat file

Transport parameters include the necessary hydrologic, erosion and sediment constants.

Table 5.2 presents parameters of transport.dat file and corresponding data sources.

Table 5.2: Parameters for the Transport File

\begin{tabular}{|c|c|c|}
\hline Parameter & Description & Data Source \\
\hline Source area estimates & $\begin{array}{l}\text { Sub-unit of land defined by different land } \\
\text { use/cover types }\end{array}$ & Land use/cover layer \\
\hline Soil curve number & $\begin{array}{l}\text { The relative amounts of surface runoff } \\
\text { and infiltration occurring at a given } \\
\text { location }\end{array}$ & $\begin{array}{l}\text { Land use/cover layer } \\
\text { Soil layer }\end{array}$ \\
\hline Soil Erodibility (K) Factor & $\begin{array}{l}\text { A measure of inherent soil erosion } \\
\text { potential, and is primarily a function of } \\
\text { soil texture and composition }\end{array}$ & $\begin{array}{l}\text { Land use/cover layer } \\
\text { Soil layer }\end{array}$ \\
\hline Slope-Length (LS) Factor & $\begin{array}{l}\text { Additional factor used in the Universal } \\
\text { Soil Loss Equation (USLE) equation. }\end{array}$ & $\begin{array}{l}\text { DEM grid layer, basin boundary } \\
\text { layer, total length of streams within } \\
\text { the watershed }\end{array}$ \\
\hline $\begin{array}{l}\text { Cropping Management }(\mathrm{C}) \\
\text { and Erosion Control Practice } \\
\text { (P) Factors }\end{array}$ & $\begin{array}{l}\text { These are two additional factors used in } \\
\text { the USLE equation }\end{array}$ & $\begin{array}{l}\text { Default value from MapShed: Evans } \\
\text { and Corradini } 2012\end{array}$ \\
\hline $\begin{array}{l}\text { Evapotranspiration cover } \\
\text { coefficients }\end{array}$ & $\begin{array}{l}\text { The ratio of water loss by } \\
\text { evapotranspiration from ground and plants } \\
\text { compared }\end{array}$ & $\begin{array}{c}\text { Coefficients are assigned by land } \\
\text { use/cover type: Evans and Corradini } \\
2012\end{array}$ \\
\hline Daylight hours & $\begin{array}{l}\text { The length of direct and indirect sunlight } \\
\text { during the daytime }\end{array}$ & $\begin{array}{l}\text { Computed automatically for } \\
\text { watershed }\end{array}$ \\
\hline $\begin{array}{l}\text { Rainfall Erosivity } \\
\text { Coefficients }\end{array}$ & $\begin{array}{l}\text { Additional factor used in the Universal } \\
\text { Soil Loss Equation (USLE) equation. }\end{array}$ & GWLF Manual: Haith et al. 1992 \\
\hline $\begin{array}{l}\text { Groundwater Seepage } \\
\text { Coefficient }\end{array}$ & $\begin{array}{c}\text { Groundwater seepage basically refers to } \\
\text { that fraction of infiltrated water that is lost } \\
\text { to an underlying aquifer or deep saturated } \\
\text { zone }\end{array}$ & GWLF Manual: Haith et al. 1992 \\
\hline Growing season months & $\begin{array}{l}\text { A period of plant growth : growing season } \\
\text { (April } 15 \text { - Oct. 15), } 0=\text { non-growing } \\
\text { season (Oct. 16-April 14) }\end{array}$ & WV Department of Agriculture \\
\hline Recession coefficient & $\begin{array}{l}\text { Estimated from historical stream flow } \\
\text { records using standard hydrograph } \\
\text { separation techniques }\end{array}$ & GWLF Manual: Haith et al. 1992 \\
\hline Sediment delivery ratio & $\begin{array}{l}\text { Proportion of the material } \\
\text { eroded from the land surface }\end{array}$ & GWLF Manual: Haith et al. 1992 \\
\hline
\end{tabular}


Land use/cover, soil, and DEM grid layers for the Greenbrier River watershed provide data for estimation of source area, soil curve number, soil erodibiliy $(\mathrm{K})$ factor, and slope-length (LS) factor. Information about the growing season months for West Virginia was collected from the WV Department of Agriculture. Default values of MapShed model were used for all other parameter to create the transport file.

Nutrient.dat file

The nutrient file contains information for calculating nitrogen and phosphorus runoff from various land use type. Table 5.3 presents the parameters of nutrient file and data sources.

Table 5.3: Parameters for the Nutrient File

\begin{tabular}{lc}
\hline Parameter & Data sources \\
\hline Dissolved N in runoff by land cover type & Default value: GWLF Manual: Haith et al. \\
& 1992 \\
Dissolved P in runoff by land cover type & Default value: GWLF Manual: Haith et al. \\
& 1992 \\
Point source's TN and TP loads & EPA's online Discharge Monitoring Report \\
& (DMR) 2010 \\
Background P concentrations in soil & Evans and Corradini (2007) \\
Background N concentrations in soil & Evans and Corradini (2007) \\
\hline
\end{tabular}

Weather.dat file

The Weather.dat file requires actual temperature and precipitation data from a weather station within the Greenbrier River watershed. These data were collected from the US National Climatic Data Center which includes weather data from 1990 to 2011. A shape file of weather station links the temperature and precipitation data stored in the associated excel files.

\subsubsection{WQM ESTIMATION, VALIDATION, AND CALIBRATION}

All GIS data layers prepared for water quality modeling were loaded to MapShed using GIS Data Layer Loading Tool. After loading GIS data and checking data layers, layer alignment, and weather data, the MapShed GWLF interface was used to crate GWLF input files (weather, 
transport, and nutrient) for each sub-watershed. A GWLF model was run to calculate streamflow, TN, and TP loads for the 1990-2011 periods for each sub-watershed.

The overall goal of water quality modeling was to estimate total nitrogen (TN) and total phosphorus (TP) discharge from the agricultural sources in the Greenbrier river watershed. Thus, the outcomes of the water quality model need to be more accurate to get valid results. In the first step, the water quality model was estimated without calibration allowing default parameters for the hydrological components and the dissolved nutrient transport components of the model. In the second step, accuracy of the model estimation was evaluated based on three parameters: stream flow, nitrogen concentration, and phosphorus concentration. This validation process required collecting stream flow and nutrients concentration data for the simulation periods of this study. In the third step, model was calibrated to predict TN and TP discharges from the various land use categories in the watershed.

\section{Observed Stream Flow}

Monthly stream flow data (cubic meter per second) were obtained from the National Water Information System (NWIS) of the U.S. Geographical Survey. The NWIS provides stream flow data for few locations in the Greenbrier River. Stream flow data for Greenbrier River at Alderson was most appropriate for model validation which includes all years (January 1990 September 2011) considered in the model simulation.

\section{Observed Dissolved Nitrogen and Phosphorus}

U.S. Environmental Protection Agency's STORET Legacy Data Center provides observed data for dissolved nitrogen and phosphorus at different locations in the Greenbrier River. Data for majority of the locations does not include dissolved nitrogen and phosphorus for the simulation period (1990-2011). Many locations have the nutrient concentration data before 
1990 which were not appropriate for model validation. Monthly dissolved nitrogen and phosphorus data for Greenbrier River at Alderson was obtained for the year 1990.

\section{Validation and Calibration of the Model}

The water quality model was validated by comparing estimated versus observed monthly data for stream flow, dissolved nitrogen, and dissolved phosphorus. For stream flow, the validation period was 1990 through 2011. For nitrogen and phosphorus, the validation period was January 1990 through November 1990.

Two statistics were used as measures of model performance. First, the Nash-Sutcliffe coefficient $\left(\mathrm{r}^{2}\right)$ was estimated to measure the goodness of fit of model estimated versus observed data. This coefficient is used to assess the predictive power of hydrological models (Nash and Sutcliffe, 1970). The $r^{2}$ statistic ranges from $-\infty$ to 1 . Prediction from the model can be more accurate with the $r^{2}$ value closer to 1 . As $r^{2}$ values become much less than 1 , this indicates the model predicted values are less accurate.

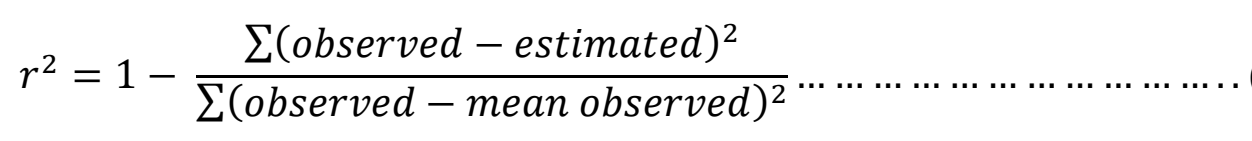

Another statistic was mean T-test between observed and estimated values of stream flow, dissolved nitrogen, and dissolved phosphorus for the simulation period. In addition to these statistics, estimated and observed values were plotted in graph for visual inspection of differences in estimated and observed values.

This study used the water quality model through minimal calibration. The model required seasonal stream flow calibration. The only parameter that required adjustment during seasonal stream flow calibration was the ground-water recession coefficient. A suitable ground-water recession coefficient for model calibration was determined (as reported below) using different coefficients and comparing estimated and observed seasonal stream flows. The calibrated water 
quality model estimates stream flows with minimum variations between estimated and observed values. The performance for the calibrated model was assessed in a similar manner using NashSutcliffe coefficient and mean T-test.

Monthly monitored and estimated stream flows in the Greenbrier River at Alderson are compared in Figure 5.5. Nash-Sutcliff coefficient of model efficiency for the non-calibrated model was 0.61 and $\mathrm{R}^{2}$ value in regression analysis between observed and estimated was 0.65 . A null hypothesis of no difference between observed and estimated monthly stream flows in the simulation period cannot be rejected. The mean t-test between monthly observed stream flows and estimated stream flows was not significant. These statistical tests indicate that the water quality model predicts stream flows with minimum errors.

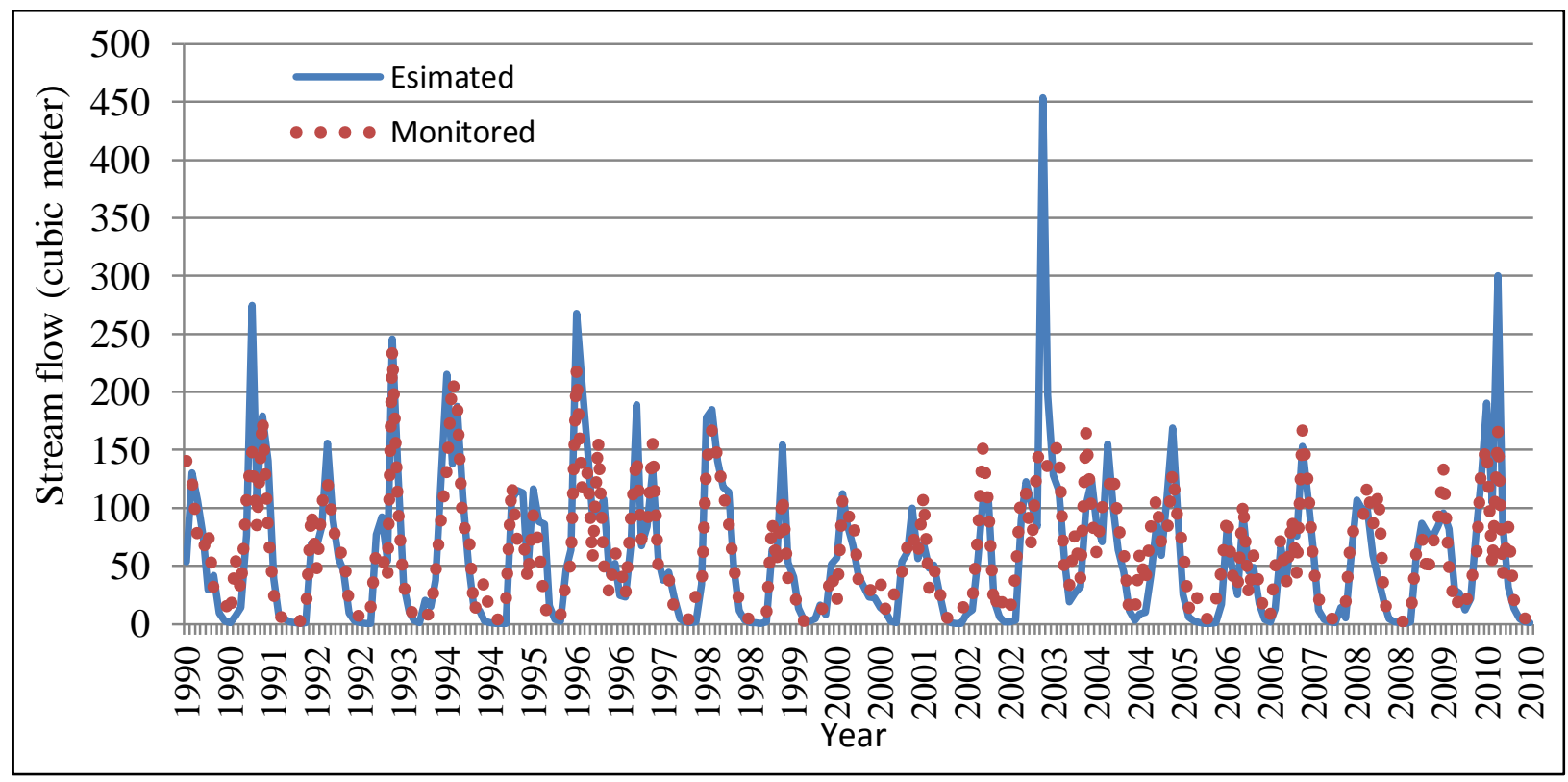

Figure 5.5: Monthly Monitored and Estimated Stream Flow in Alderson, Greenbrier River (NonCalibrated Model)

The differences between estimated and observed values were high for low stream flow months. This difference was minimized by adjusting the ground-water recession coefficient. The ground-water recession coefficient value of 0.02 provided better results than other values range 
between 0.01 and 0.20 . Monthly monitored stream flow in the Greenbrier River at Alderson and estimated stream flows simulated from the calibrated model are compared in Figure 5.6. This calibrated model adjusted seasonal variations in the stream flows. The performance for the calibrated model was assessed in a similar manner to non-calibrated model: using Nash-Sutcliff coefficient, $\mathrm{R}^{2}$ value, and t-test. The Nash-Sutcliff coefficient of model efficiency for calibrated model was 0.63 and $\mathrm{R}^{2}$ value in regression analysis between observed and estimated was 0.71 . In the calibrated model, the null hypothesis of no difference between observed and estimated monthly stream flows in the simulation period cannot be rejected. The statistical tests for model preference indicate that the calibrated model predicts stream flow better than non-calibrated model.

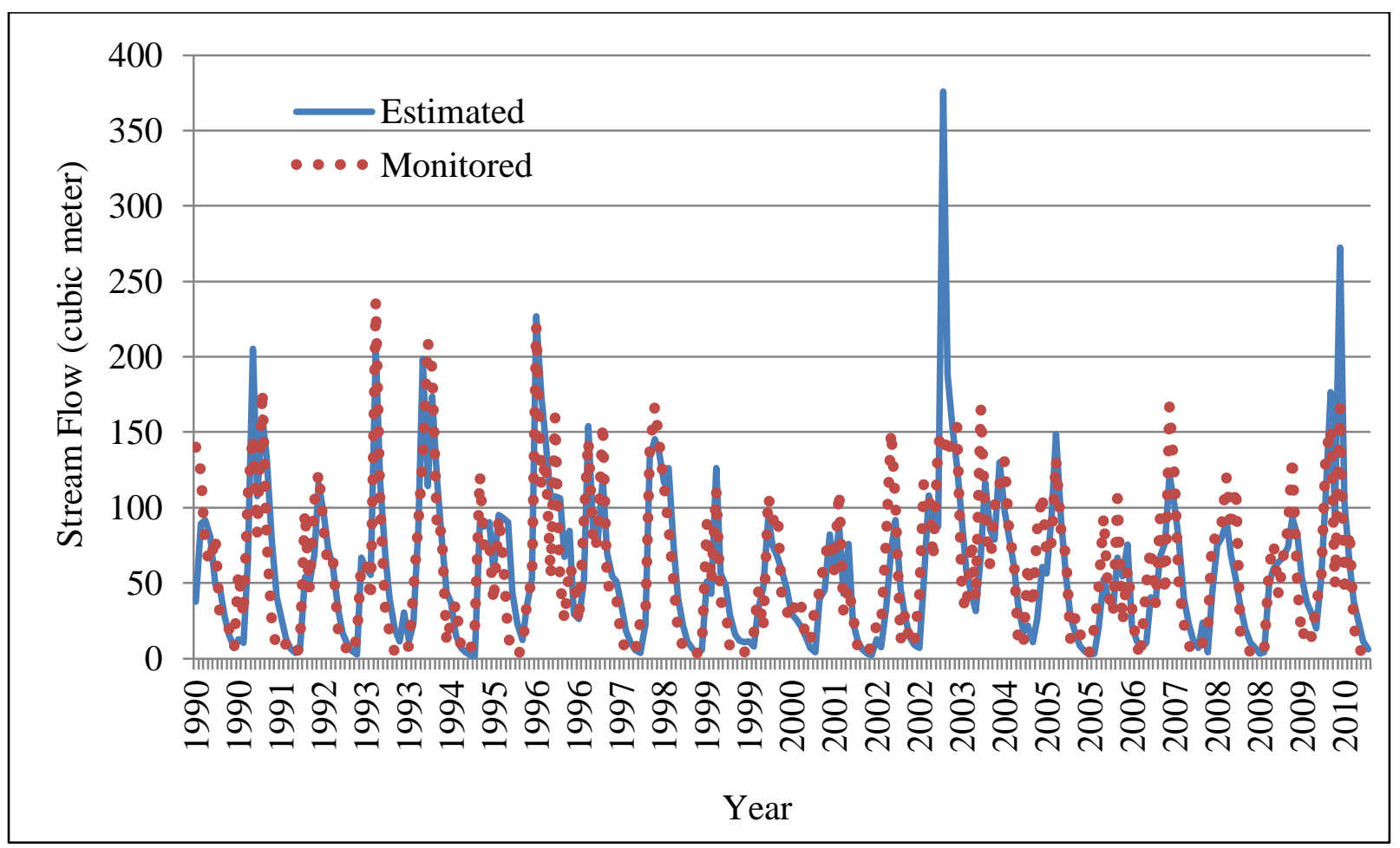

Figure 5.6: Monthly Monitored and Estimated Stream Flow in Alderson, Greenbrier River (Calibrated Model)

Final validation for the water quality model was done by comparing estimated and observed TN and TP loads. As mentioned early, data for dissolved concentration of TN and TP 
were available only for the year 1990 at the Alderson water quality monitoring station of Greenbrier River. Monthly monitored and estimated dissolved nitrogen and phosphorus in the Greenbrier River at Alderson are compared in Figures 5.7 and 5.8. The small number of observations for dissolved nitrogen and phosphorus and lack of very recent water quality observations gave unsatisfactory statistical results. The water quality model used 2010 land cover data for Greenbrier River watershed where land use patterns could be significantly different than the land use pattern in 1990. This difference in land cover resulted slightly different level of nutrient discharge. The model was limited by lack of sufficient water quality monitoring data for nutrient discharge calibration. The model with stream flow calibration was used to estimate nutrient reduction from the implementation of agricultural BMP in the Greenbrier River watershed.

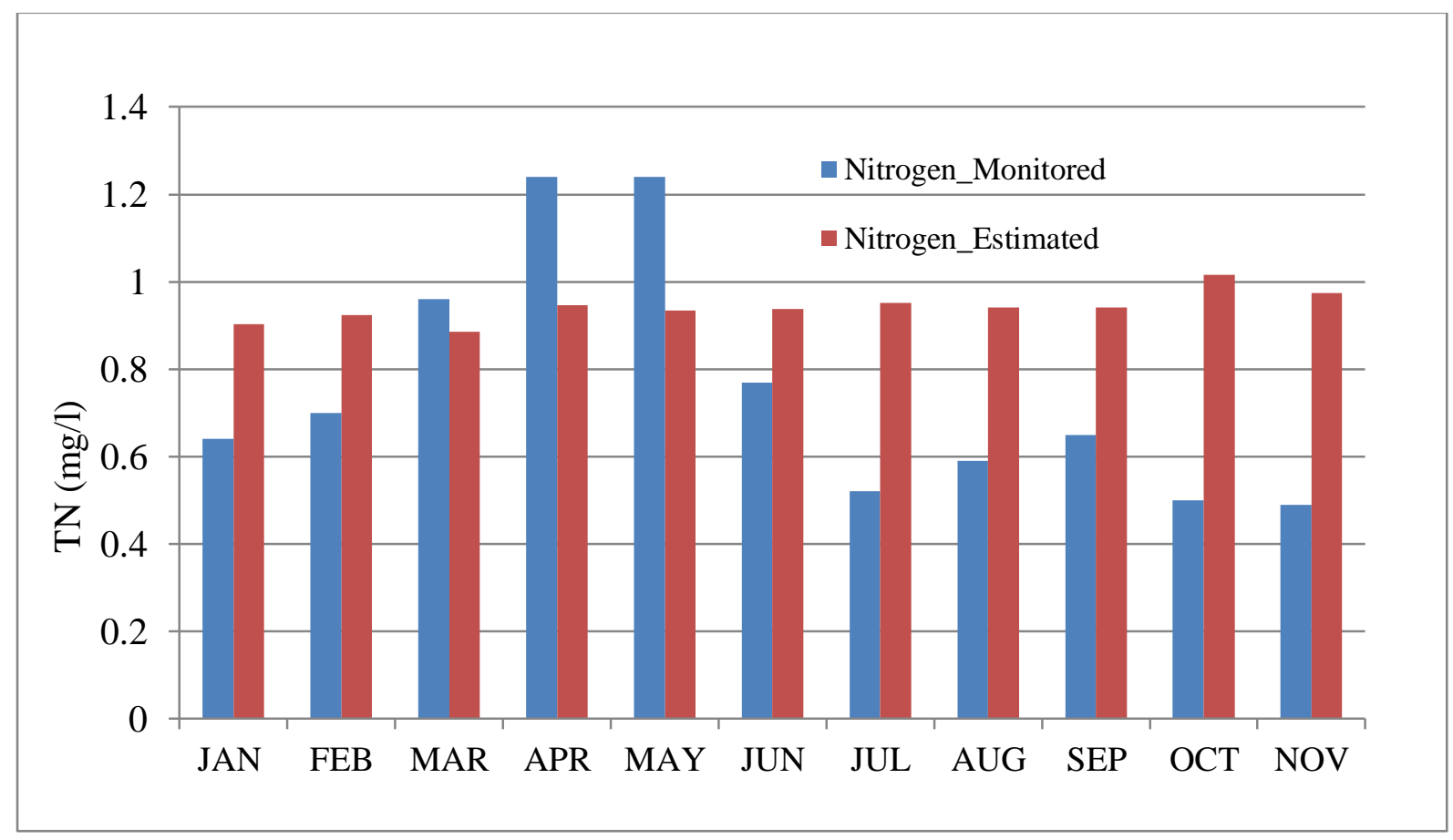

Figure 5.7: Monthly Monitored and Estimated TN (mg/l) In Greenbrier River at Alderson 


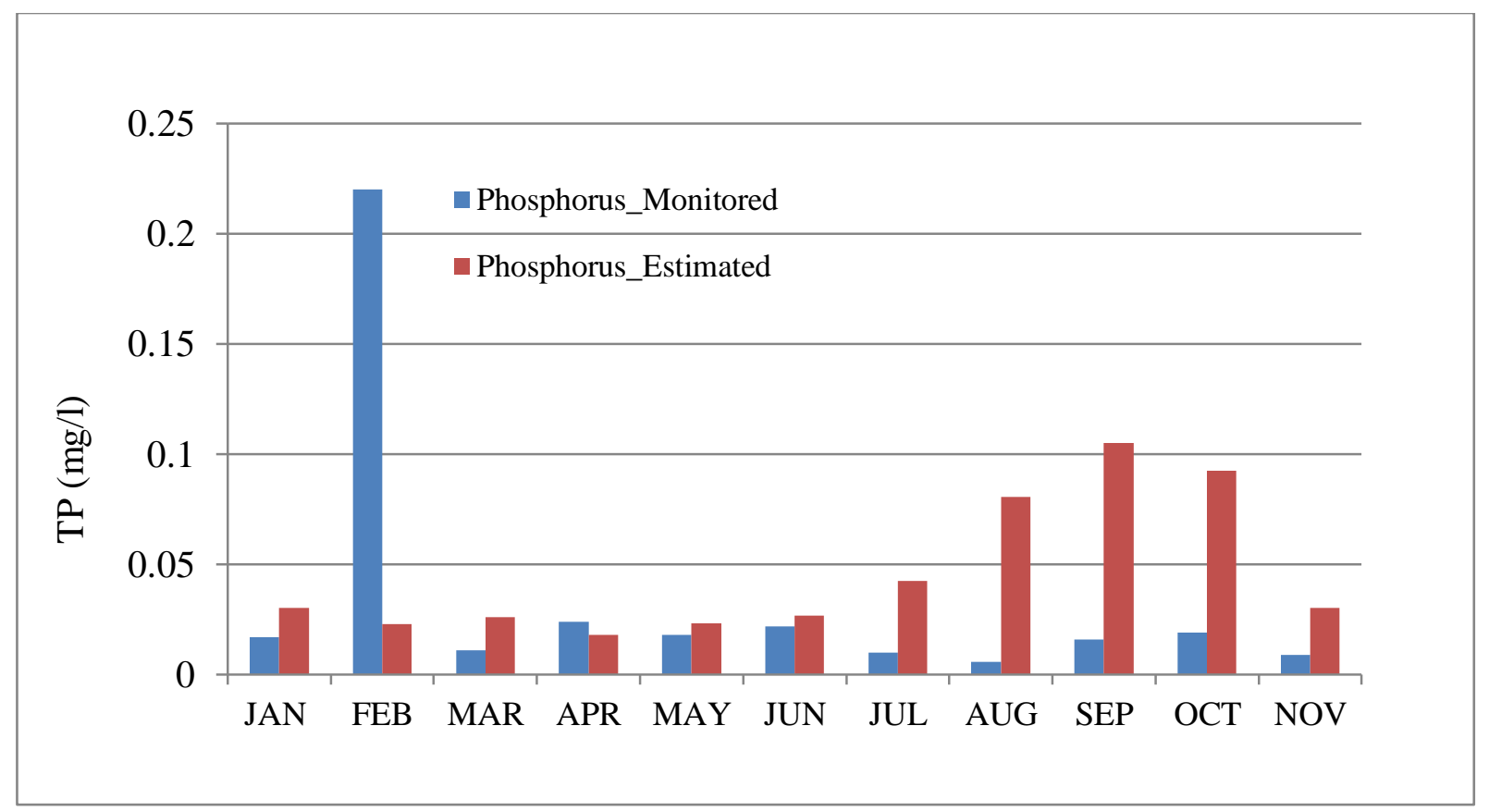

Figure 5.8: Monthly Monitored and Estimated TP (mg/l) in Greenbrier River at Alderson

\subsection{ESTIMATION OF POTENTIAL NUTRIENT CREDIT SUPPLY}

Potential TN and TP credit supply from agricultural sources was estimated using the MapShed model. The MapShed is an extended version of Generalized Watershed Loading Function (GWLF) (Evans et al. 2002) which can be used to model sediment and nutrients transport within a watershed (Evans and Corradini 2012). The calibrated MapShed model was used to estimate TN and TP loads discharge from each sub-watershed of Greenbrier River watershed based on the sub-watershed wide data, the default GWLF values in MapShed, and the calibrated ground-water recession coefficient. First, the model estimates TN and TP loadings from the various land use categories without considering the existing level of BMPs. Second, the model estimates TN and TP loadings from the various land use categories considering the existing level of BMPs. These estimates represent maximum amount of TN and TP loadings at the mouth of each sub-watershed with and without considering current level of BMP on the 
ground and future BMP levels. Third, the model is used to evaluate potential load reductions for future BMP levels.

\subsubsection{SELECTION OF BMPS FOR WATER QUALITY MODELING}

Two BMPs for crop land (cover crop and nutrient management plan) and two BMPs for pasture and grassland (prescribed grazing and a nutrient management plan) were selected based on the results of a survey of agricultural BMPs in the Greenbrier County (described below in section 3.8). These BMPs were selected based on several criteria. 1) These BMPs were the most common ones implemented in the study area. This survey showed that a large proportion of farmers implement cover crop and nutrient management plans on crop lands and nutrient management plans and grazing land management on pasture/hay and grasslands. 2) These BMPs involve changes in farm operation rather than structural improvements on the farm and the PRedICT tool in the MapShed model simulates operational BMPs more accurately than structural BMPs. 3) Suitable input data for structural BMPs were not available in the BMP survey and NRCS data.

The PRedICT tool in MapShed required the following data: 1) land area under different land use categories, 2) current level of BMP application, 3) pollution reduction efficiencies for each BMP, and 4) costs for BMP implementation (in either $\$ /$ ha or $\$ /$ acre). The BMP implementation costs were collected from the USDA NRCS West Virginia payment schedules for the 2012 Environmental Quality Incentive Program (EQIP) (NRCS 2012). The EQIP payment schedule was provided based on a BMP unit cost basis (\$/acre). The cost information indicates that the EQIP payment covers $100 \%$ cost of implementing cover crop, nutrient management plan, and prescribed grazing in WV (WVNRCS 2012). Table 5.4 presents costs and reduction efficiency for each BMP used in PRedICT. The per acre cost of a cover crop (single 
species), nutrient management (inorganic fertilizer and manure), and prescribed grazing (rotational feeding) was $\$ 37.35, \$ 24.06$, and $\$ 25.50$, respectively. Cover crop and nutrient management plans can reduce phosphorus more efficiently than prescribed grazing. The nitrogen reduction efficiency is similar for all three BMPs.

Table 5.4: BMP Costs and Reduction Efficiencies

\begin{tabular}{lccc}
\hline BMP & $\begin{array}{c}\text { Costs } \\
(\$ / \text { acre) }\end{array}$ & $\begin{array}{c}\text { Nitrogen Reduction } \\
\text { Efficiency }(\%)\end{array}$ & $\begin{array}{c}\text { Phosphorus Reduction } \\
\text { Efficiency }\end{array}$ \\
\hline $\begin{array}{l}\text { Cover Crop (Single Species) } \\
\text { Nutrient Management Plan }\end{array}$ & 24.35 & 0.29 & 0.50 \\
(Inorganic Fertilizer and Manure) & 25.50 & 0.29 & 0.44 \\
$\begin{array}{l}\text { Prescribed Grazing } \\
\text { (Rotational Feeding) }\end{array}$ & 25.50 & 0.30 \\
\hline
\end{tabular}

\subsubsection{ESTIMATION OF TN AND TP CREDIT SUPPLY}

Potential TN and TP credits supply were estimated based on demand driven supply estimation method. In the demand driven supply, supplier produces goods (credits) considering consumer demand in the market. In the water quality trading market estimation of demand driven nutrient credit supply requires information about nutrient demand in downstream of the watershed (or sub-watershed). Section 4.5 discusses estimation method of potential nutrients credit demand (i.e. nutrient reduction requirements for WWTPs). Total nutrient reduction requirements for WWTPs in a watershed depends on nutrients limits in their discharges and trading ratios. More stringent nutrient limits and higher trading ratios require more nutrient supply from the agricultural sources. In addition to this, baseline requirements for agricultural sources influence on the level of credit supply. Table 5.5 presents agricultural nutrient credit supply scenarios examined in this research. All of these 12 nutrient credit supply scenarios were analyzed under two markets: single nutrient WQT market and combined nutrients WQT market. 
Table 5.5: Agricultural Source's Nutrient Credit Supply Scenarios

\begin{tabular}{|c|c|c|c|c|}
\hline \multirow[t]{2}{*}{ Scenario } & \multirow[t]{2}{*}{ Trading ratio } & \multicolumn{2}{|c|}{ Effluent limitations for WWTPs } & \multirow{2}{*}{$\begin{array}{l}\text { Baseline requirements for } \\
\text { agricultural sources }\end{array}$} \\
\hline & & TN Concentration & TP Concentration & \\
\hline 1 & $1: 1$ & $8.0 \mathrm{mg} / \mathrm{l}$ & $1.0 \mathrm{mg} / \mathrm{l}$ & Existing BMPs level \\
\hline 2 & $1: 1$ & $5.0 \mathrm{mg} / \mathrm{l}$ & $0.5 \mathrm{mg} / \mathrm{l}$ & Existing BMPs level \\
\hline 3 & $1: 1$ & $3.0 \mathrm{mg} / \mathrm{l}$ & $0.1 \mathrm{mg} / \mathrm{l}$ & Existing BMPs level \\
\hline 4 & $2: 1$ & $8.0 \mathrm{mg} / \mathrm{l}$ & $1.0 \mathrm{mg} / \mathrm{l}$ & Existing BMPs level \\
\hline 5 & $2: 1$ & $5.0 \mathrm{mg} / \mathrm{l}$ & $0.5 \mathrm{mg} / \mathrm{l}$ & Existing BMPs level \\
\hline 6 & $2: 1$ & $3.0 \mathrm{mg} / \mathrm{l}$ & $0.1 \mathrm{mg} / \mathrm{l}$ & Existing BMPs level \\
\hline 7 & $1: 1$ & $8.0 \mathrm{mg} / \mathrm{l}$ & $1.0 \mathrm{mg} / \mathrm{l}$ & $100 \%$ NMP \\
\hline 8 & $1: 1$ & $5.0 \mathrm{mg} / \mathrm{l}$ & $0.5 \mathrm{mg} / \mathrm{l}$ & $100 \%$ NMP \\
\hline 9 & $1: 1$ & $3.0 \mathrm{mg} / \mathrm{l}$ & $0.1 \mathrm{mg} / \mathrm{l}$ & $100 \%$ NMP \\
\hline 10 & $2: 1$ & $8.0 \mathrm{mg} / \mathrm{l}$ & $1.0 \mathrm{mg} / \mathrm{l}$ & $100 \%$ NMP \\
\hline 11 & $2: 1$ & $5.0 \mathrm{mg} / \mathrm{l}$ & $0.5 \mathrm{mg} / \mathrm{l}$ & $100 \%$ NMP \\
\hline 12 & $2: 1$ & $3.0 \mathrm{mg} / \mathrm{l}$ & $0.1 \mathrm{mg} / \mathrm{l}$ & $100 \%$ NMP \\
\hline
\end{tabular}

NMP $=$ Nutrient Management Plan

A draft statewide water quality trading framework and basin specific nutrient trading guidance for the Potomac River and tributaries provides the baseline requirements for agricultural sources (WVWRI 2008a, WVWRI 2008b). The framework notes that agricultural operations must fulfill their portion of the nutrient reduction requirements before generating credits. They require implementing at least nutrient management plan under the water quality trading framework. This study estimated potential supply under two baseline scenarios: existing BMP level ("Timed Baseline") and 100\% nutrient management plan ("Minimum Standard Baseline").

In the nutrients reduction estimation process, the low cost BMP was selected first for the simulation in the MapShed model. It was assumed that all farmers will prefer low cost BMP to generate nutrient credits. For example, cover crops and conservation tillage can generate nutrient credits at lower costs than other BMPs in the agricultural lands (CTIC 2011). This study first estimates total nutrients reduction from the implementation of a cover crop in the agricultural lands in all sub-watersheds. Other BMPs (i.e. nutrient management plans in crop lands and grass/pasture lands) were considered to meet the remaining demand of nutrient credits for the 
WWTPs. It was assumed that farmers will implement high cost BMPs if demand for nutrient credit still exists in the WQT market and farmers have potential to generate credits from the implementation of high cost BMPs. Iterative simulation of the calibrated water quality model estimates the levels of BMPs required to implement on crop and pasture/hay/grassland to meet the nutrient credit demand for different scenarios. Agricultural land under each BMP and total amount of TN and TP credits were calculated based on the simulation results. All total, fourteen water quality models, one for each sub-watershed, were simulated.

\subsubsection{ESTIMATION OF COST OF TN AND TP CREDIT}

Costs of $\mathrm{TN}$ and $\mathrm{TP}$ credit were estimated for single nutrient trading market and combined nutrient trading market. For a single nutrient trading market (either TN or TP), the cost of credit generation from the implementation of BMP was estimated based on following formula:

$$
\operatorname{Cost}(\$ / \mathrm{lb})=\frac{\text { Total Area }(\text { acre }) \times \text { Cost }(\$ / \text { acre })}{\text { Total Reduction }(\mathrm{lb} .)} \ldots \ldots \ldots \ldots \ldots \ldots
$$

This study assumed linear cost function for all BMPs implementation. The payment from the cost-share program does not differ according to the area of BMPs implementation. The average cost of nutrient reduction $(\$ / \mathrm{lb}$.) represents the minimum level of price that a farmer is willing to accept (WTA) to sell his/her nutrient credit in the WQT market. Simulation of water quality model considering different BMPs for each sub-watershed level determines what the interval of possible credit prices will be in the watershed.

Estimation of the per unit cost of TN and TP credit in a combined nutrient trading market was the most complicated to compute. It required partition of total cost of BMP implementation into two portions: (1) costs for TN reduction, and (2) costs for TP reduction. One appropriate technique to divide total cost into two separate categories can be based on nutrient inflow to the agricultural land. This study considered recommended nutrient applications for corn in WV to 
calculate the proportion of nitrogen and phosphorus inflow to the agricultural land. Nitrogen $(\mathrm{N})$ $160 \mathrm{lb} . / \mathrm{acre}$ and phosphorus $\left(\mathrm{P}_{2} \mathrm{O}_{5}\right) 50 \mathrm{lb}$./acre were considered as a general recommended application corn in WV (J. Gorman, personal communication, March 20, 2012). Dr. Gorman mentioned that fertilizer doses differ according to soil test reports. The nutrient inflow rate was estimated after conversion of nutrient dose to elemental $\mathrm{N}$ and $\mathrm{P}$.

Total elemental $\mathrm{N}$ and $\mathrm{P}$ inflow $=160+50 * 0.44=182\left(0.44\right.$ is conversion factor for $\mathrm{P}_{2} \mathrm{O}_{5}$ to elemental P)

Proportion of $\mathrm{N}$ inflow $=160 / 182=0.88$, and

Proportion of $\mathrm{P}$ inflow $=50 * 0.44 / 182=0.12$

Thus, total cost of nutrient reduction was divided into cost of TN reduction and cost of TP reduction based on the proportion of $\mathrm{N}$ and $\mathrm{P}$ inflow.

\subsection{ESTIMATION OF POTENTIAL NUTRIENT CREDIT DEMAND}

Estimating potential nutrient credit demand from the wastewater treatment plants requires information about current treatment process and amount of pollutants discharge, pollutant load reduction requirement to meet the new discharge limitations, and costs of technology upgrades for the pollutant reduction. The cost of meeting the new discharge limitation depends on the current level of treatment operation and the cost associated with upgrading the current treatment system. This information helps to estimate the per unit cost of nitrogen and phosphorus reduction for the WWTPs. This section explains data sources and methods applied for the estimation of potential credit demand in the Greenbrier River watershed.

\subsubsection{CURRENT TREATMENT SYSTEM}

Information on the type of wastewater treatment used by WWTPs within the Greenbrier River watershed was obtained from the Clean Watersheds Needs Survey (CWNS). The CWNS 
categorizes treatment levels into two groups: Secondary WWT and Advanced WWT. Secondary WWT requires maintaining $30 \mathrm{mg} / \mathrm{l}$ of both biochemical oxygen demand (BOD5) and total suspended solids (TSS) and must remove 85 percent of BOD5 and TSS from the discharge (EPA 2008). Trickling filters or activated sludge process is used in the secondary treatment. Advanced WWT is used for nutrients removal including additional BOD5, TSS and removal of toxic chemicals. The advanced treatment process goes beyond secondary treatment and includes the removal of excess nutrients such as nitrogen and phosphorus. This category needs a substantial fund to attain a level of treatment that is more stringent than secondary treatment. Table 5.6 presents the CWNS information for all significant WWTPs in the Greenbrier River watershed. It indicates that all facilities have secondary WWT system.

Table 5.6: Summary of CWNS Information for Significant Facilities in the Greenbrier River

\begin{tabular}{lcc} 
& Watershed & \\
\hline Facility Name & Facility Description & Treatment Level \\
\hline Town of Alderson & WWTP & Secondary \\
City of Ronceverte & WWTP & Secondary \\
Union PSD & WWTP & Secondary \\
Pence Springs & WWTP & Secondary \\
City of White Sulfur Springs & WWTP & Secondary \\
Town of Hillsboro & WWTP & Secondary \\
City of Marlinton & WWTP & Secondary \\
\hline
\end{tabular}

Source: USEPA 2008 (Clean Watersheds Needs Survey (CWNS))

The Secondary Treatment Regulations of WV specify certain effluent limitation for BOD5, TSS, and $\mathrm{pH}$ in the individual permits of WWTP. Based on the types of treatment processes specified in the CWNS and the Secondary Treatment Regulations of WV, it appears that almost none of the WWTPs in the Greenbrier River watershed are targeting the treatment of total nitrogen and total phosphorus. Upgrades of current treatment processes would therefore be necessary to meet more stringent water quality based effluent limitations for nitrogen and phosphorus. 


\subsubsection{EXISTING POLLUTANT LOADS}

Information about the existing pollutant load from the NPDES permit holders in the Greenbrier River watershed was obtained from the EPA's online Discharge Monitoring Report (DMR). Data include the amount and concentration of total nitrogen and total phosphorus discharge from NPDES permitted facilities. Average pollutant loads and concentration in the discharge are presented as pounds per day and $\mathrm{mg} / \mathrm{l}$ for each facility. Table 5.7 presents existing nutrient loads from the seven NPDES permitted facilities in the Greenbrier River watershed. Data for the year 2010 was latest available data. The size of the facilities ranges between 0.064 and 1.31 Million Gallon per Day (MGD). Five out of seven facilities have more than $10 \mathrm{mg} / \mathrm{l}$ nitrogen concentration in their discharges. All facilities have more than $1 \mathrm{mg} / \mathrm{l}$ phosphorus concentration in their discharges.

Table 5.7: Existing Nutrient Loads from Permitted NPDES Facilities in the Greenbrier Watershed

\begin{tabular}{lccccc}
\hline & & \multicolumn{2}{c}{ Total Nitrogen } & \multicolumn{2}{c}{ Total Phosphorus } \\
\cline { 3 - 6 } Facility & $\begin{array}{c}\text { Actual Flow } \\
(\mathrm{MGD})\end{array}$ & $\begin{array}{c}\text { Concentration } \\
(\mathrm{mg} / \mathrm{l})\end{array}$ & $\begin{array}{c}\text { Daily load } \\
(\mathrm{lb} / \mathrm{day})\end{array}$ & $\begin{array}{c}\text { Concentration } \\
(\mathrm{mg} / \mathrm{l})\end{array}$ & $\begin{array}{c}\text { Daily load } \\
(\mathrm{lb} / \mathrm{day})\end{array}$ \\
\hline Town of Alderson & 0.280 & 11.77 & 24.89 & 2.28 & 7.62 \\
City of Ronceverte & 0.970 & 19.65 & 143.45 & 3.18 & 24.60 \\
Union PSD & 0.080 & 16.22 & 13.98 & 2.23 & 2.00 \\
Pence Springs & 0.480 & 15.88 & 32.56 & 4.02 & 16.09 \\
City of White Sulfur & & & & & \\
Springs & 1.310 & 7.22 & 53.08 & 2.18 & 18.67 \\
Town of Hillsboro & 0.064 & 19.15 & 5.28 & 2.95 & 3.42 \\
City of Marlinton & 0.210 & 10.21 & 25.05 & 1.57 & 3.21 \\
\hline SOunyyyy
\end{tabular}

Source: EPA 2010 (Discharge Monitoring Report (DMR) Pollutant Loading Tool)

\subsubsection{ESTIMATION OF NUTRIENTS REDUCTION REQUIREMENT FOR WWTP}

The information about existing pollutant loads and concentration in the discharge helps to estimate the load reduction requirement for the WWTPs under different permit effluent limits. For the purpose of the WQT feasibility analysis, total nitrogen and phosphorus load reduction 
requirements were estimated under three effluent limits. Assumptions were made about likely future nutrients discharge limits that would result from numeric nutrient criteria based on the nutrient criteria adopted for Chesapeake Bay tributaries strategies. For purposes of the WQT feasibility analysis, different scenarios of nutrient discharge limits for nitrogen and phosphorus were assumed. In this research, $8 \mathrm{mg} / \mathrm{l}, 3 \mathrm{mg} / \mathrm{l}$ and $5 \mathrm{mg} / \mathrm{l}$ for $\mathrm{TN}$ and $1.0 \mathrm{mg} / \mathrm{l}, 0.5 \mathrm{mg} / \mathrm{l}$ and $0.1 \mathrm{mg} / 1$ for TP were considered. The calculation method for nitrogen and phosphorus load reduction requirement is given below:

\section{Estimation of Nutrient Load Reduction at Different Effluent Limits}

The nutrient load reduction requirement for individual WWTPs was estimated based on the current average daily load (lbs.), design flow, and expected nutrient limit (mg/l) for the WWTP in the watershed. The following formulae were used to estimate the nutrient load reduction requirement for WWTPs.

Current average daily load (lb.) of all WWTPs was converted to current average daily load (mg) using a conversion factor:

Current average daily load in $\mathrm{mg}\left(\mathrm{Q}_{1}\right)=$ current average daily load (lb.) * 453,592.37

Where $1 \mathrm{lb} .=453,592.37 \mathrm{mg}$

Total expected daily load in mg at different effluent limits were estimated by converting design flow to total liters of water discharge in a day and multiply by effluent limit:

Total expected load in mg per day $\left(\mathrm{Q}_{2}\right)=$ Total flow per day (liters) * e

Where $\mathrm{e}=\mathrm{TN}$ or $\mathrm{TP}$ concentration limit $(\mathrm{mg} / \mathrm{l})$

Total required reduction in lb. per day $\left(\mathrm{Q}_{3}\right)=\left(\mathrm{Q}_{1}-\mathrm{Q}_{2}\right) / 453,592.37$

Estimated annual load (lbs.) reduction requirement $\left(\mathrm{Q}_{4}\right)=\mathrm{Q}_{3} * 365$ 
The estimated annual load reduction requirement was assumed to be the potential demand for nutrient reduction credits for each facility in the Greenbrier River watershed. The total amount of credit purchase from the point source depends on the trading ratios used in water quality trading program. A trading ratio indicates how many units of nitrogen or phosphorus reduction a point source needs to purchase to compensate for one unit of required load reduction. For example, a WWTP in need of 2,000 pounds of annual total phosphorus load reduction to meet $0.5 \mathrm{mg} / 1 \mathrm{TP}$ limit may actually need to buy $2,000,4,000$, or 6,000 at $1: 1,2: 1$ or $1: 3$ trading ratios, respectively. Nutrient credit demands for all WWTPs in the Greenbrier River basin were estimated for 1:1 and 2:1 trading ratios. Most of the currently active WQT programs in the US are using either 1:1 or 2:1 trading ratio between the non-point and point sources. This approach addresses the effect of these trading ratios on the potential WQT market in Greenbrier River watershed. Table 5.8 shows WWTP's nutrient credit demand scenarios.

Table 5.8: WWTP's Nutrient Credit Demand Scenarios

\begin{tabular}{lccc}
\hline Scenario & Trading ratio & TN Concentration & TP Concentration \\
\hline 1 & $1: 1$ & $8.0 \mathrm{mg} / \mathrm{l}$ & $1.0 \mathrm{mg} / 1$ \\
2 & $1: 1$ & $5.0 \mathrm{mg} / 1$ & $0.5 \mathrm{mg} / 1$ \\
3 & $1: 1$ & $3.0 \mathrm{mg} / 1$ & $0.1 \mathrm{mg} / 1$ \\
4 & $2: 1$ & $8.0 \mathrm{mg} / 1$ & $1.0 \mathrm{mg} / 1$ \\
5 & $2: 1$ & $5.0 \mathrm{mg} / 1$ & $0.5 \mathrm{mg} / 1$ \\
6 & $2: 1$ & $3.0 \mathrm{mg} / 1$ & $0.1 \mathrm{mg} / 1$ \\
\hline
\end{tabular}

\subsubsection{ESTIMATION OF NUTRIENTS REDUCTION COSTS FOR WWTP}

The potential credit demand in a watershed depends on the costs for upgrading current treatment process to provide enhanced nutrient removal (ENR) of total nitrogen and total phosphorus. The costs of upgrading WWTP facilities include both increased capital costs and operations and maintenance costs (O\&M). The estimation methods developed by the Nutrient Reduction Technology Cost Task Force, Chesapeake Bay Program in 2002 (CBP 2002) was used 
to estimate the additional costs to WWTP from nitrogen and phosphorus reductions for point sources in the Greenbrier River watershed. This Task Force collected biological nutrient reduction (BNR) cost related data from 126 facilities located in the Chesapeake Bay watershed (PA, MD, VA, WV, NY and D.C.) and estimated the capital and O\&M cost for 644 facilities. All facilities were categorized into four groups: Tier 1, Tier 2, Tier 3, and Tier 4. Tier 1 represents facilities' current discharge levels which were used as a baseline for cost estimation. Tier 2, Tier 3, and Tier 4 were the facilities that require meeting nitrogen limits of $8.0 \mathrm{mg} / \mathrm{l}, 5.0 \mathrm{mg} / \mathrm{l}$, and 3.0 mg/l, respectively. Cost estimates for Tier 2, Tier 3, and Tier 4 represents the incremental costs require to achieve total nitrogen $(\mathrm{TN})$ concentrations of $8.0 \mathrm{mg} / 1,5.0 \mathrm{mg} / \mathrm{l}$, and $3.0 \mathrm{mg} / \mathrm{l}$ and total phosphorus concentration of $1 \mathrm{mg} / \mathrm{l}, 0.5 \mathrm{mg} / \mathrm{l}$, and $0.1 \mathrm{mg} / \mathrm{l}$. Nitrogen and phosphorus removal processes involve different associated operations and maintenance costs. Therefore, the Nutrient Reduction Technology Cost Task Force's used separate approaches for nitrogen and phosphorus removal cost estimation.

According to the Nutrient Reduction Technology Cost Task Force's estimation, all WWTPs need to construct denitrification zones and extend aeration processes in the existing treatment system to achieve $8.0 \mathrm{mg} / \mathrm{l}$ total nitrogen in their discharges. All facilities need to add chemical treatment system. The costs for WWTPs to achieve $5.0 \mathrm{mg} / \mathrm{l}$ total nitrogen include additional aeration, a secondary anoxic zone plus methanol addition, additional clarification tankage, and additional chemical costs to achieve a phosphorus discharge of $0.5 \mathrm{mg} / \mathrm{l}$. The costs for WWTPs to achieve $3.0 \mathrm{mg} / \mathrm{l}$ total nitrogen include deep bed denitrification filters and microfiltration to achieve a phosphorus discharge of $0.1 \mathrm{mg} / \mathrm{l}$.

This research considered seven WWTPs in the Greenbrier River watershed for the cost estimation. These seven WWTPs were NPDES permitted facilities with high levels of nitrogen 
and phosphorus discharges. The report of the Nutrient Reduction Technology Cost Estimations for point sources in the Chesapeake Bay watershed presents capital and O\&M costs for all 644 facilities according to the design flow of the facilities. This cost estimation report of 644 facilities includes design flows of all seven WWTPs considered in this study. Thus, the capital and O\&M costs for all seven WWTPs in the Greenbrier River watershed were borrowed from the cost estimation report based on their design flow. It was assumed that WWTPs in the Greenbrier River watershed require the same capital and O\&M costs for upgrading the treatment plant expend by the WWTPs in the Chesapeake Bay watershed for year 2002 .

\section{Cost Adjustment and Computation of Annualized Costs}

All capital and O\&M cost estimates for the facilities in the Greenbrier River watershed were adjusted to 2011 US\$ using the US producer price index (i.e. increased by 27\%). The real treasury interest rate for different maturities was used for annualized cost of capital investments. The real treasury interest rate for the year 2011 with 20-year maturity life was 2.1 percent. Equation for a factor that was used to Annualized Cost Computation:

$\mathrm{a}(\mathrm{r}, \mathrm{n})=\left[\mathrm{r}(1+\mathrm{r})^{\mathrm{n}}\right] /\left[(1+\mathrm{r})^{\mathrm{n}}-1\right]$

Where:

$$
\begin{aligned}
& a(r, n)=\text { Annualized Cost Factor } \\
& r=\text { real treasury interest rate } \\
& n=\text { usable life of capital asset }
\end{aligned}
$$

The cost per pound of nutrient reduction was calculated for each point source by dividing the total annualized capital plus O\&M cost by the total annual nutrient load reduction needed for each point source. Twenty years usable life of capital asset was assumed for the annualized cost estimation. 


\subsubsection{ESTIMATION OF COST OF TN AND TP REDUCTION}

Costs of TN and TP reduction for WWTP were estimated for single nutrient trading market as well as combined nutrient trading markets. For the single nutrient trading market (either TN or TP), the cost of nutrient reduction from the facility upgrading was estimated based on following formula:

Average Cost $(\$ / \mathrm{lb})=\frac{\text { Annual Capital Cost }(\$)+\text { Annual O \& M Cost }(\$)}{\text { Annual Load Reduction Requirement (lb.) }}$

A linear cost function for facility upgrading was assumed. The average additional cost of nutrient reduction $(\$ / \mathrm{lb}$.) represents the maximum level of price that WWTP would be willing to pay (WTP) to purchase nutrient credit in the WQT market.

The cost of nutrient reduction for WWTPs in a combined nutrients trading market was estimated based on the level of nutrients inflow in the treatment process. The current levels of nutrients discharges $(\mathrm{mg} / \mathrm{l})$ were considered as nutrient inflow for the new treatment process. Information about the existing level of nutrient discharge for all seven WWTPs in the Greenbrier River watershed was obtained from the EPA's online Discharge Monitoring Report. Similar to agricultural sources, the proportions of $\mathrm{N}$ and $\mathrm{P}$ inflow for each treatment facility were estimated using nutrient inflow data. Total capital cost of nutrient reduction for each facility was divided into cost of TN reduction and cost of TP reduction based on the proportion of $\mathrm{N}$ and $\mathrm{P}$ inflow. The WWTP requires separate O\&M cost for $\mathrm{N}$ and $\mathrm{P}$ reduction.

\subsection{WQT FEASIBILITY ANALYSIS}

The WQT analysis assesses the feasibility of nutrient trading between agricultural sources and WWTPs under 12 different WQT scenarios in the watershed. All 12 WQT scenarios include different effluent limitations for WWTPs, trading ratios, and baseline requirements for the agricultural sources (Table 12). All of these 12 nutrient credit supply scenarios were analyzed 
under two markets: single nutrient WQT market and combined nutrients WQT market. This analysis relied on the outcomes of watershed model, costs for BMPs in crop and pasture lands, and estimation of WWTP's nutrient abatement costs. In this study, two levels of WQT feasibility analyses were carried out: 1) watershed level using aggregate demand for and supply of nutrient credits (TN and TP), and 2) TN and TP trading feasibility for the individual WWTP.

\section{Assumptions for Market Feasibility Analysis}

The nutrient market feasibility analysis in this study assumes a perfectly competitive market for nutrient credits trading. However, unlike other markets for environmental goods and services, The WQT market has small number of buyers (WWTPs) and large number of sellers (farmers). This asymmetrical market can provide more bargaining power to WWTPs. The following assumptions were made for WQT feasibility analysis:

a. Market structure - bilateral negotiations: WWTPs will directly contact or recruit farmers

b. Legal authority- WVDEP assigns compliance and enforcement provisions. It will also impose penalty for violations

c. Unit of trade: One unit of TP or TN reduction from agricultural sources will be equal to one unit of TN or TP reduction from WWTP. One unit is equal to one pound of TN or TP.

d. Duration of credit: one year and no credit carry over provision

e. This study assumes that all WWTPs choose either treatment plant upgrade or purchase of nutrient credits from the WQT market. No WWTP will consider a combination of treatment plant upgrading and WQT to comply with any effluent limitations.

f. Transaction costs: assume that there are no transaction costs involved in recruiting trading partners, regulatory approval and other trading activities 
g. Trading ratio: uncertainly in credit generation by non-point sources will be minimized by assigning appropriate trading ratios between agricultural sources and WWTPs

\section{Estimation of Aggregate Potential Demand and Supply}

The WQT feasibility analysis based on aggregate demand and supply assumes that a watershed is a single market and that the direction of trading will not produce local water quality problems in downstream portions. All buyers can purchase nutrient credits from sellers either upstream or downstream. This type of trading can increase economic suitability of nutrient trading in the WQT program. First, unlike upstream-only trading, the demand for and supply of credits is not localized so that scope of nutrient credit trading increases. Second, WWTPs located in the upstream areas of the watershed can get enough credits to fulfill their demand purchasing from elsewhere. Environmentally, allowing this type of trading has the potential to produce water quality problems downstream from point sources. This type of trading only can be suitable if the watershed goal is to reduce overall nutrient discharge at the mouth of the watershed.

This aggregate analysis assessed the supply of credits to fulfill aggregate demand under different trading ratios, nutrient limits, and baseline requirements. The levels of BMPs implementation to meet aggregate $\mathrm{TN}$ and $\mathrm{TP}$ demand were estimated from the simulation of water quality model. The analysis also presents the possible range of WTP and WTA under single and combined nutrient credit market.

\section{Estimation of Net Economic Benefits}

The level of economic incentive likely generated by a nutrient trading is an important factor for the feasibility of WQT in a watershed. A WQT program which can reduce pollutant loadings in a watershed should be financially feasible to create a viable market. This section compares estimated net economic benefits from the WQT between agricultural sources and 
WWTPs under different trading ratios, effluent limits for WWTPs, and baseline requirements for agricultural sources.

A graphical method was applied to find out the equilibrium market price and measure the area of consumer surplus and producer surplus under each scenario in the graphs. The area under the demand curve and above the price line represents the consumer (WWTPs) surplus and the area above the supply curve and below the price line represents the producer (Farmers) surplus. Both demand and supply curves were nonlinear under all 12 scenarios. Approximate consumer and producer surpluses were calculated through finding the areas algebraically. The areas under consumer and producer surpluses were divided to calculate the area of each shape. Summation of calculated areas provides approximate consumer and producer surpluses under each scenario.

The total economic benefits were estimated for single nutrient market and combined nutrients markets. The single nutrient market represents phosphorus trading under different TP limitations for WWTPs, trading ratios, and baseline requirements for agricultural sources. The goal of all WWTPs in Greenbrier River watershed is to reduce TP from their discharge. A market for TN credits was included to drive down the equilibrium price of TP credits. It was assumed that TN credit demand generates no economic benefit other than its impact on the TP credit market. The net economic benefits in a single market and combined market under each scenario were estimated using following formula:

Single Nutrient Market:

$$
\mathrm{NEB} 1=(\mathrm{CS} 1+\mathrm{PS} 1)-\mathrm{TTC} 1 \ldots \ldots \ldots \ldots \ldots . . . .6 .6
$$

Where, NEB1 = Net Economic Benefit in a Single Nutrient Market, CS1 = Consumer Surplus in a Single Nutrient Market, PC1 = Producer Surplus in a Single Nutrient Market, TTC1 = Total Treatment Upgrade Costs for TP from Non-Participants in the Market 
When a TP standard is implemented in the watershed, all WWTPs choose either to purchase TP credits from the WQT market or to upgrade their treatment plants to meet the TP reduction requirement based on the cost of compliance. WWTP were assumed not to both purchase TP credits and upgrade, but to do only one. Thus, the net economic benefit represents the total economic benefit minus total costs for WWTPs (i.e. TP credit purchase cost plus treatment plant upgrading cost for those WWTP not purchasing credits).

Combined Nutrients Market:

$$
\mathrm{NEB} 2=(\mathrm{CS} 2+\mathrm{PS} 2)-\mathrm{TNC}-\mathrm{TTC} 2 \ldots \ldots \ldots \ldots \ldots \ldots .7
$$

Where, NEB2 = Net Economic Benefit from TP Trading in a Combined Nutrients Market, CS2 = Consumer Surplus from TP Trading in a Combined Nutrients Market, PC2 = Producer Surplus from TP Trading in a Combined Nutrients Market, TNC = Total Cost of Providing TN by Farmers, and TTC2 $=$ Total Treatment Upgrade Costs for TP and TN from Non-Participating WWTP in the Credit Markets.

For a combined nutrients market, it was assumed that all WWTPs utilized a combined nutrients reduction technology (i.e. Biological Nutrient Reduction) to reduce $\mathrm{TP}$ and $\mathrm{TN}$ simultaneously. Similarly, the agricultural sources were assumed to implement BMPs which can reduce both TP and TN. The total cost of nutrient reduction was divided into TP reduction costs and TN reduction costs based on the proportion of TP and TN inflow (sections 5.4.3 and 5.5.5). The total cost of $\mathrm{TP}$ reduction decreases under the combined nutrients reduction system compared to the single nutrient reduction system. Thus, per unit cost of $\mathrm{TP}$ and $\mathrm{TN}$ reduction significantly reduced and both the demand and supply curves for TP credits shift down in a combined nutrient market (Figure 3.2). 


\section{Upstream-only Trading}

This analysis includes only phosphorus credit trading because phosphorus problem in the Greenbrier River watershed under 12 different WQT scenarios. Results of this analysis indicate the potential impacts of effluent limits for WWTPs, trading ratios, baseline requirement for agricultural sources, market type in the percentage of the cost saving estimates for individual WWTP.

In the upstream-only trading system, buyers can purchase credits only from upstream sellers. The USEPA and WV WQT guidelines indicate that trading must not produce any water quality problem locally or downstream (USEPA 2003, WVDEP 2009). This upstream-only trade can improve downstream nutrient problems largely avoiding the development of hotspot. This study analyzed upstream-only trading for each WWTP in the watershed. This analysis estimates potential cost saving for individual WWTP.

$\%$ of Cost Saving $=\frac{B T C-T C C}{T C C} * 100$

Where, BTC $=$ WWTP's (buyers) total cost of nutrient reduction without trading, TCC $=$ Total cost of credit purchased under trading.

\subsection{IMPACT OF EXISTING LEVEL OF BMPS ON THE WQT MARKET}

This study analyzed the potential impact of existing level of BMPs on the future WQT market. The existing level of BMPs at the farmer's field can influence to the amount of marketable nutrient credit generation, cost of credit, and farmer's participation in the potential WQT market in a watershed. Moreover, existing level of BMPs and selection of the baseline for agricultural sources can have a direct impact on the overall performance of WQT market. This section of analysis used data from the survey of farm BMPs in the crop and pasture land in 
Greenbrier County, WV. Data includes 112 crop land and 66 pasture/grassland farmers and provides information about types and level of BMPs implemented in the crop and pasture/grasslands.

Method of Estimating Credit Generation from Individual Farms

When using MapShed, the user cannot estimate nutrient reductions at a farm level. The user has to estimate nutrient reductions from the implementation of BMPs at a sub-watershed level and extrapolate the results for all farms within the sub-watershed. This study estimated per acre nutrient reduction (lb/acre) from each BMP at the sub-watershed level. Per acre nutrient reductions from each BMP differ between sub-watersheds. The study assumed that per acre nutrient reductions from each BMP within a sub-watershed do not vary significantly.

Spatial locations of the 178 survey respondents were identified based on the parcel ID number of crop and pasture lands. A parcel level map for each tax district in the survey area was available on the website of Greenbrier County Assessor's Office. Spatial information of respondents helped to locate them in sub-watershed (Figure 5.9). 


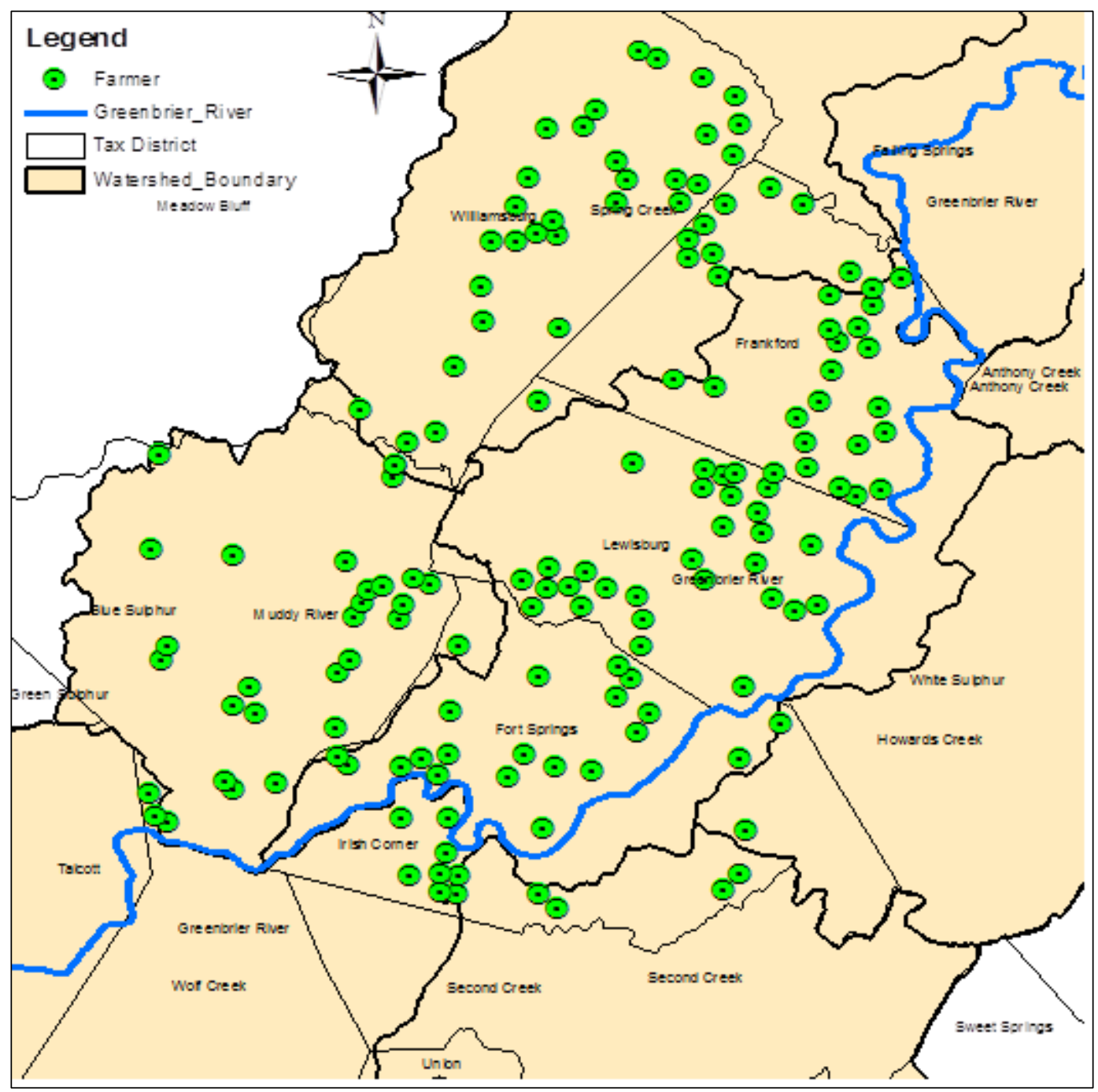

Figure 5.9: Location of the Survey Respondents in the Greenbrier River Watershed

Survey data provided each respondent's land area under crop and pasture/grasslands. For each respondent, the amount of nutrient discharges and potential reduction from BMPs implementation in the crop and pasture/grasslands were calculated using results of sub-watershed level simulation.

\section{Existing BMPs and Baseline Requirements}

In the current water quality trading related literature, two types of baselines for agricultural sources are widely discussed. The first baseline is consideration of the existing level of BMPs at a specific date as the baseline (called a 'timed baseline'). BMPs implemented after 
that date would generate credits. The second type of baseline is a minimum standard baseline under which each farmer must maintain minimum level of particular management practice or set of practices to be eligible to generate credits from the implementation of other BMPs.

All respondents were separated into two groups for comparison under the two baseline scenarios. In the timed baseline scenario, one group includes all respondents with some level of BMPs in their crop or/and pasture lands (self BMP implementer). Another group includes others without BMPs on their crop or/and pasture lands (self BMP non-implementer). In the minimum standard baseline scenario, respondents who were ex-ante adopters of the minimum standard BMP i.e. nutrient management plan were called as good stewards. All respondents who have not implemented the minimum standard BMP were called as poor stewards.

\section{Method of Analysis}

The selection of baseline and impact of existing level and type of BMPs on WQT markets were analyzed for efficiency and equity implications. In the first step, the cost (\$/lb.) and amount of credit generation were estimated under two different baselines. In the second step, the number of potential participants cost of credits, and amount of credit generation between ex-ante BMP implementers and non- implementers under two different baselines were analyzed. Whether a particular baseline under existing BMP level would be equitable or efficient was evaluated based on the cost of credit generation, amount of credits, and number of participation in the potential WQT market. 


\section{CHAPTER 6: RESULTS AND DISCUSSION}

\subsection{INTRODUCTION}

Chapter 5 described the methods and techniques used for the survey of BMPs, water quality modeling, demand for and supply of nutrient credit estimation, and water quality feasibility analysis. This chapter presents results generated from the survey and modeling techniques, interprets, and discusses the empirical results.

\subsection{FARM BEST MANAGEMENT PRACTICES}

\subsubsection{CHARACTERISTICS OF RESPONDENTS}

Average land holding size of crop land owner respondents was 33.95 acres and pasture land owner respondents was 147.45 acres. Table 6.1 shows the type of land management for crop and pasture land. Most of the respondents (70.79\%) reported that they are actively managing their agricultural land. About $10 \%$ of respondents leased their land to another farmer, but are actively involved in its management. About one-sixth of respondents (15.17\%) lease their agricultural lands to other farmers and are not involved in its management. Only $2.81 \%$ of respondents currently leave their land idle. Among the responses, one crop land owner has quit farming and another has given his crop land to his nephew and is not involved in management.

Table 6.1: Type of Land Management based on Survey Responses

\begin{tabular}{|c|c|c|c|}
\hline Land Management & Crop & Pasture & Total \\
\hline As owner, I actively manage this land & $82(73.21 \%)$ & $44(66.67 \%)$ & $126(70.79 \%)$ \\
\hline The land is currently idle. & $4(3.57 \%)$ & $1(1.52 \%)$ & $5(2.81 \%)$ \\
\hline $\begin{array}{l}\text { The land is leased to another farmer } \\
\text { and I take an active role in its } \\
\text { management. }\end{array}$ & $8(7.14 \%)$ & $10(15.15 \%)$ & $18(10.11 \%)$ \\
\hline $\begin{array}{l}\text { The land is leased and I am not } \\
\text { involved in its management. }\end{array}$ & $16(14.29 \%)$ & $11(16.67 \%)$ & $27(15.17 \%)$ \\
\hline Other & $2(1.79 \%)$ & 0 & $2(1.12 \%)$ \\
\hline Total & 112 & 66 & 178 \\
\hline
\end{tabular}


Table 6.2 presents survey responses on the type of farm operations in the study area. Survey responses show that major farm operation in Greenbrier County is livestock and hay $(63.48 \%)$. This response is consistent with the latest USDA agricultural census data. According to the agricultural census, Greenbrier County ranks first in beef cattle farming, second in forage cultivation for hay and silage, fourth in sheep and goat farming, and sixth in milk and other dairy production among 55 counties in WV (USDA 2007). The agricultural census for the County also indicates that $75.25 \%$ farms raise livestock, $74.57 \%$ of farms cultivate harvested crops, and $69.12 \%$ of farms produce hay and forage crops. About $12 \%$ of respondents reported hay production as their primary operation and about $10 \%$ of respondent operations were either livestock and crop, crop only, dairy only, or other. In this survey, more than two-thirds of the crop land owners $(68.04 \%)$ responded that livestock and hay production was their major farm operation.

Table 6.2: Types of Farm Operations based on Survey Responses

\begin{tabular}{lcc}
\hline Farm Operation & Number of Responses & Percent \\
\hline Livestock and hay & 113 & 63.48 \\
Livestock and crop & 6 & 3.37 \\
Hay & 22 & 12.35 \\
Crop & 1 & 0.56 \\
Dairy & 5 & 2.80 \\
Other & 7 & 3.93 \\
No response & 24 & 13.48 \\
Total & 178 & 100 \\
\hline
\end{tabular}

Table 6.3 presents the percentage of annual household income that comes from farming among survey respondents. Farm income contributes less than $25 \%$ of annual household income for over half of all respondents. This shows that farming is not a full-time occupation for majority of the respondents. For about $15 \%$ of respondents, farming is a substantial portion of annual household income, contributing over 50\%. 
Table 6.3: Percentage of Annual Household Income from Farming (2010)

\begin{tabular}{lcc}
\hline Income Share & Number of Responses & Percent \\
\hline $0-10 \%$ & 83 & 46.62 \\
$11-25 \%$ & 20 & 11.23 \\
$26-50 \%$ & 18 & 10.11 \\
$51-75 \%$ & 7 & 3.93 \\
$76-90 \%$ & 6 & 3.37 \\
$91-100 \%$ & 12 & 6.74 \\
No response & 32 & 17.97 \\
Total & 178 & 100 \\
\hline
\end{tabular}

\subsubsection{EXISTING LEVELS OF BMPS}

The survey questions presented lists of BMPs suitable for crop and pasture land. Table 6.4 presents crop land owner responses for BMPs implemented at the farmer's expense and with cost sharing from the Natural Resources Conservation Service (NRCS). Regular soil testing (38.39\%), no-till on cropland (28.57\%), nutrient management plan (28.57\%), planting of cover crops $(20.53 \%)$, and grassed waterway $(13.39 \%)$ are the most common BMPs implemented by majority of the farmers with own expenses and NRCS cost share in the crop lands.

Table 6.4: Best Management Practices on Crop Lands ( $\mathrm{n}=112)$

\begin{tabular}{lccc}
\hline BMP & $\begin{array}{c}\text { BMP implemented } \\
\text { with own expenses }\end{array}$ & $\begin{array}{c}\text { BMP implemented } \\
\text { with NRCS cost share }\end{array}$ & $\begin{array}{c}\text { Total } \\
\text { responses }\end{array}$ \\
\hline Soil testing conducted regularly & $41(36.60 \%)$ & $17(15.17 \%)$ & $43(38.39 \%)$ \\
Nutrient management plan & $22(19.64 \%)$ & $14(12.5 \%)$ & $32(28.57 \%)$ \\
No-till on cropland & $27(24.10 \%)$ & $14(12.5 \%)$ & $32(28.57 \%)$ \\
Planting of cover crops & $21(18.75 \%)$ & $4(3.57 \%)$ & $23(20.53 \%)$ \\
Grassed waterway & $14(15.5 \%)$ & $7(6.25 \%)$ & $15(13.39 \%)$ \\
Stream buffers & $6(5.35 \%)$ & $5(4.46 \%)$ & $10(8.92 \%)$ \\
Planting of trees in along streams & $4(3.57 \%)$ & $2(1.78 \%)$ & $4(3.57 \%)$ \\
Stream bank restoration & $6(5.35 \%)$ & $2(1.78 \%)$ & $5(4.46 \%)$ \\
Others & $8(7.14 \%)$ & $8(7.14 \%)$ & \\
None & $35(31.25 \%)$ & $75(66.96 \%)$ & \\
\hline Non
\end{tabular}

Note: percent in none category indicates the farmers without any BMPs on their crop lands.

Stream buffers $(8.92 \%)$, planting of trees in along streams (3.57\%), and stream bank restoration (4.46\%) are less common BMPs implemented in the survey area. Survey data show 
that many farmers implement different BMPs with their own cost in the crop land. This survey showed that the large percentage of crop and pasture land owners are not implementing any listed BMPs with their own expenses $(31.25 \%)$ or with NRCS cost share $(66.96 \%)$.

Crop land owners also were asked about their interest in implementing BMPs. "None" was by far the most common response. Among those interested in BMPs, a nutrient management plan and regular soil testing had the highest responses at $17.85 \%$ and $16.96 \%$ of respondents, respectively (Table 6.5). Very few farmers were interested in implementing grassed waterways, stream buffers, and stream bank restoration. In total, about $36 \%$ respondents were interested in implementing at least one BMP in their crop land. Among them, about one-fourth and one-fifth respondents have already implemented at least one BMP at their own expense and with NRCS cost share, respectively. Only 5.35\% respondents who have not implemented any BMPs were interested to implement some BMPs in their crop land.

Table 6.5: Interest in Implementing Best Management Practices on the Crop Lands $(\mathrm{n}=112)$

\begin{tabular}{lc}
\hline BMP & Interest in implementing BMP \\
\hline Nutrient management plan & $20(17.85 \%)$ \\
Soil testing conducted regularly & $19(16.96 \%)$ \\
No-till on cropland & $10(8.92 \%)$ \\
Others & $9(8.03 \%)$ \\
Planting of cover crops & $7(6.25 \%)$ \\
Planting of trees in along streams & $5(4.46 \%)$ \\
Stream bank restoration & $4(3.57 \%)$ \\
Grassed waterway & $3(2.67 \%)$ \\
Stream buffers & $2(1.78 \%)$ \\
None & $71(63.39 \%)$ \\
\hline
\end{tabular}

Table 6.6 presents survey responses by pasture land owners to each BMPs. Watering facility (50\%), prescribed grazing management (48.48\%), fencing of livestock from streams (28.78\%), nutrient management plan $(27.27 \%)$, and winter grazing areas away from stream (19.69\%) were the BMPs implemented by majority of pasture land owner at their own expenses and/or with NRCS cost share. Less than $10 \%$ of respondents indicated an interest in the 
implementation of animal waste storage facility, planting of trees in along streams, stream buffers, or stream bank restoration.

Table 6.6: Best Management Practices on the Pasture Lands $(n=66)$

\begin{tabular}{lccc}
\hline BMP & $\begin{array}{c}\text { BMP } \\
\text { implemented with } \\
\text { own expenses }\end{array}$ & $\begin{array}{c}\text { BMP implemented } \\
\text { with NRCS cost } \\
\text { share }\end{array}$ & $\begin{array}{c}\text { Total responses } \\
\text { on particular } \\
\text { BMP }\end{array}$ \\
\hline $\begin{array}{l}\text { Watering facility } \\
\text { Prescribed grazing management }\end{array}$ & $\begin{array}{c}28(42.42 \%) \\
\text { Fencing of livestock from }\end{array}$ & $\begin{array}{c}24(36.36 \%) \\
14(21.21 \%)\end{array}$ & $32(46.96 \%)$ \\
streams & $10(15.15 \%)$ & $10(15.15 \%)$ & $19(28.78 \%)$ \\
Nutrient management plan & $15(22.72 \%)$ & $11(16.66 \%)$ & $18(27.27 \%)$ \\
Winter grazing areas away from & $11(16.66 \%)$ & & $13(19.69 \%)$ \\
stream & $3(4.54 \%)$ & $5(7.57 \%)$ & $6(9.09 \%)$ \\
Planting of trees in along & $4(6.06 \%)$ & $4(6.06 \%)$ & $6(9.09 \%)$ \\
streams & $4(6.06 \%)$ & $2(3.03 \%)$ & $5(7.57 \%)$ \\
Stream buffers & $4(6.06 \%)$ & $4(6.06 \%)$ & $5(7.57 \%)$ \\
Stream bank restoration & $5(7.57 \%)$ & $4(6.06 \%)$ & \\
Animal waste storage facility & $21(31.81 \%)$ & $29(43.93 \%)$ & \\
Other & & & \\
None & & & \\
\hline
\end{tabular}

Note: percent in none category indicates the farmers without any BMPs on their pasture/grass lands

More than $10 \%$ of respondents showed an interest in implementing a watering facility (13.63\%), nutrient management plan (16.66\%), prescribed grazing management $(12.12 \%)$, and fencing of livestock from streams (13.63\%) in the pasture land (Table 6.7). In total, about $40 \%$ of respondents were interested in implementing at least one BMP in their pasture land. All of these $40 \%$ respondents have already implemented at least one BMP on their pasture land. Respondents who did not implement any BMPs at their own expense or with NRCS cost share did not show any interest in implementing BMPs on their pasture land. 
Table 6.7: Interest in Implementing Best Management Practices on the Pasture Lands ( $\mathrm{n}=66)$

\begin{tabular}{lc}
\hline BMP & Interest in implementing BMPs \\
\hline Nutrient management plan & $11(16.66 \%)$ \\
Watering facility & $9(13.63 \%)$ \\
Fencing of livestock from streams & $9(13.63 \%)$ \\
Prescribed grazing management & $8(12.12 \%)$ \\
Planting of trees in along streams & $5(7.57 \%)$ \\
Stream bank restoration & $5(7.57 \%)$ \\
Winter grazing areas away from stream & $3(4.54 \%)$ \\
Stream buffers & $2(3.03 \%)$ \\
Animal waste storage facility & $1(1.51 \%)$ \\
Other & $4(6.06 \%)$ \\
None & $40(60.60 \%)$ \\
\hline
\end{tabular}

BMPs were broken down into long-term investments (examples include planting trees, grassed waterways, stream bank restoration, water facility, etc.) and annual activities (examples include planting cover crops, soil testing, prescribed grazing management, etc.). The sum of responses on investment and non-investment type of BMPs in crop and pasture land are shown in Table 6.8. Many agricultural BMPSs can be implemented with minimal investments by a landowner. For instance, no-till on cropland, planting of cover crops, nutrient management plan, and prescribed grazing management require limited investment to implement annually.

Table 6.8: Type of BMPs Based on Time of Investment

\begin{tabular}{|c|c|c|c|}
\hline BMP & $\begin{array}{l}\text { BMP implemented } \\
\text { with own expenses }\end{array}$ & $\begin{array}{l}\text { BMP implemented } \\
\text { with NRCS cost share }\end{array}$ & $\begin{array}{c}\text { Interest in } \\
\text { implementing BMP }\end{array}$ \\
\hline \multicolumn{4}{|l|}{ Crop land } \\
\hline Investment (long-term) & $25(22.32 \%)$ & $12(10.71 \%)$ & $10(8.92 \%)$ \\
\hline $\begin{array}{l}\text { Non-investment } \\
\text { (annual) }\end{array}$ & $63(56.25 \%)$ & $20(17.85 \%)$ & $34(30.35 \%)$ \\
\hline \multicolumn{4}{|l|}{ Pasture land } \\
\hline Investment (long-term) & $36(54.54 \%)$ & $18(27.27 \%)$ & $15(22.72 \%)$ \\
\hline $\begin{array}{l}\text { Non-investment } \\
\text { (annual) }\end{array}$ & $31(46.96 \%)$ & $37(56.06 \%)$ & $19(28.78 \%)$ \\
\hline
\end{tabular}

Some practices such as grassed waterway, stream buffers, stream bank restoration, and animal waste management require a substantial investment and can work for long time. Because 
of such investment requirement, NRCS provides cost-share assistance, when necessary, to offset the expenses associated with the implementation of these BMPs. In this survey, $56.25 \%$ and $17.85 \%$ respondents implement at least one short-term annual BMP in the crop land with own expense and NRCS cost share, respectively. About 30\% of respondents are interested in implementing non-investment type of BMP in their crop land. Less than $25 \%$ of the cropland owners implemented long-term BMPs at their own expense and with NRCS cost share.

A relatively large proportion of pasture land owners implemented at least one long-term BMP compared with crop land owners. In this survey, $54.54 \%$ pasture land owners implemented long-term BMPs and 46.96\% implemented short-term annual BMPs in their pasture lands at their own expense. Similarly, $27.27 \%$ and $56.06 \%$ pasture land owners implemented long-term and short-term BMPs with NRCS cost share, respectively. Similar to crop land owners, a larger proportion of pasture land owners $(28.78 \%)$ are interested in implementing short-term BMPs than long-term BMPs $(22.72 \%)$.

Table 6.9 presents total and average areas of BMPs implemented for both own expense and NRCS cost share on crop and pasture land. The average per acre value was calculated by dividing total amount of BMP implemented by total acres of land over all survey responses. Grassed waterway and prescribed grazing management are two BMPs implemented in large areas in crop and pasture lands. On average, crop and pasture land owners implemented 49.31 feet/acre and 81.63 feet/acre grassed waterway and prescribed grazing management, respectively. Crop land owners implemented no-tillage practices on more than half of their crop lands. The average per acre nutrient management plan was higher on the crop land compared to the pasture/grassland. 
Table 6.9: Existing Level of BMPs Implemented in the Crop and Pasture Lands

\begin{tabular}{lcc}
\hline BMP & Total implemented & Average per acre \\
\hline Crop land & & \\
Grassed waterway (feet) & $14,418(9)$ & 49.31 \\
No-till on cropland (acres) & $424.61(16)$ & 0.59 \\
Nutrient management plan (acres) & $604.72(10)$ & 0.94 \\
Planting of cover crops (acres) & $390.5(1)$ & 0.72 \\
Planting of trees in along stream (stream feet) & $1,000(3)$ & 20 \\
Stream buffers (stream miles) & $3.93(2)$ & 0.018 \\
Stream bank restoration (stream feet) & $1800(1)$ & 135.34 \\
Pasture land & & \\
Prescribed grazing management (feet) & $90,690(7)$ & 81.63 \\
Nutrient management plan (acres) & $602(7)$ & 0.31 \\
Fencing of livestock from streams (miles) & $5.8(4)$ & 0.007 \\
Planting of trees in along streams (stream feet) & $1,200(1)$ & 6 \\
Stream buffers (stream miles) & $1.6(3)$ & 0.004 \\
Stream bank restoration (stream feet) & $5,250(2)$ & 27.52 \\
Winter grazing areas away from stream (acres) & $564(6)$ & 0.62 \\
\hline
\end{tabular}

Note: Value in the parenthesis indicates number of responses

\subsection{EXISTING NUTRIENTS LOADING IN THE GREENBRIER RIVER WATERSHED}

The water quality model simulates TN and TP for 14 sub-watersheds in the Greenbrier River watershed. These water quality simulations were based on the watershed land use characteristics of 2010. The model developed in the MapShed simulated nutrients discharges from the 22 different land use categories without considering existing BMPs. Each land use category was linked with expected loadings based on the acreage under particular land use. The model provides daily, monthly, and annual nutrient loadings from the various sources including stremflows and nutrient concentration (mg/l). The estimation of nutrient discharge from each 11digit hydrological unit (sub-watershed) was independent of the upstream loading passing through the sub-watershed.

The MapShed model estimates for the Greenbrier River watershed indicate a large amount of TN and TP discharged from the watershed. Figures 6.1 and 6.2 show simulated TN and TP loadings by sub-watershed. These loading data represent the average annual loading for 
21 years $(1990-2011)$. The estimated loading from all land use categories, including point sources and all sub-watersheds, was $6,187,826$ pounds TN and 445,410 pounds TP per year. Greenbrier 1 had the highest N and P loadings, followed by Greenbrier 2. Spring Creek, Second Creek, Greenbrier 3, and Muddy River had also high N and P loadings. Results indicate that total $\mathrm{N}$ and $\mathrm{P}$ loadings were relatively lower from the sub-watershed in the upstream of the Greenbrier River than the sub-watersheds in the downstream. The amounts of nutrient loadings were directly related to the extent of land areas under crop production and pasture/grasslands. Areas under crop production and pasture/grasslands are high in the high nutrient loadings sub-watersheds.

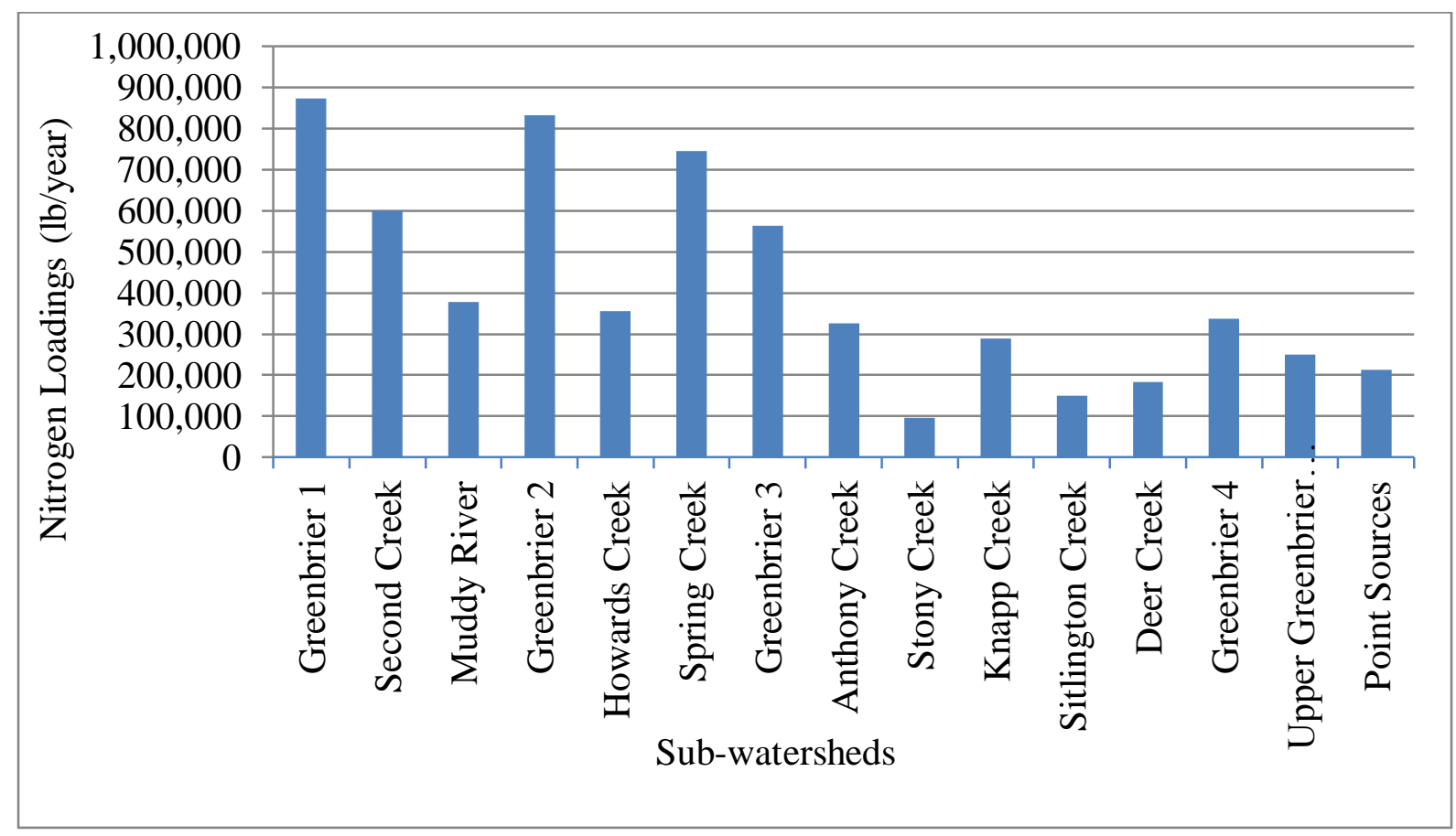

Figure 6.1: Sub-Watershed Level Average Annual Nitrogen Loadings 


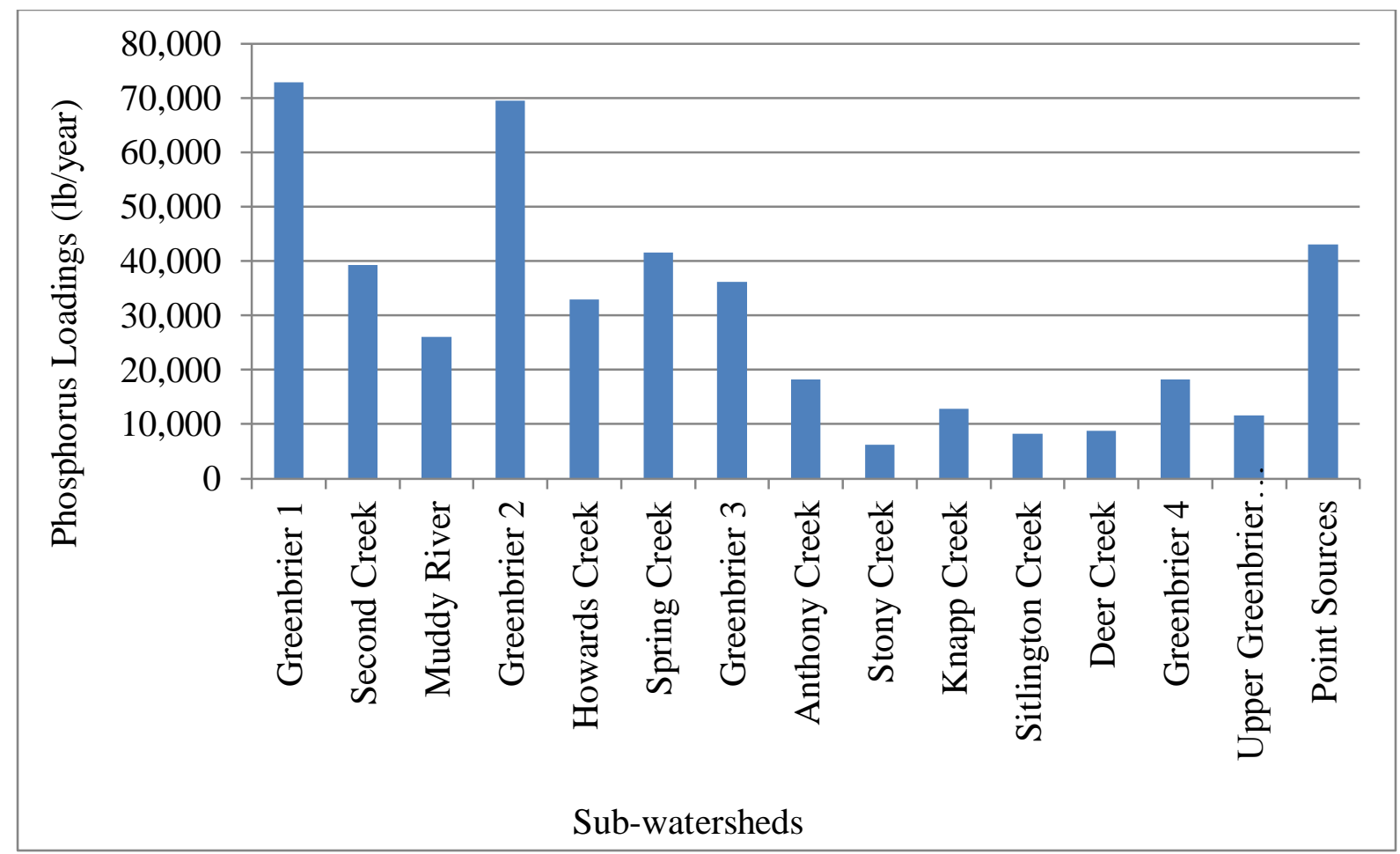

Figure 6.2: Sub-Watershed Level Average Annual Phosphorus Loadings

Forest and pasture/grasslands contribute large amount of nutrient loadings in the subwatershed at the upstream of the Greenbrier River. The estimated average annual nitrogen and phosphorus discharges from the point sources in the Greenbrier River watershed were 212,985 lb. and 43,001 lb. respectively. The total amount of TN and TP discharges from the point sources represents about $4 \%$ of total nitrogen and $10 \%$ of total phosphorus discharges in the watershed.

The MapShed model was also used to estimate existing TN and TP loading considering existing level of BMPs on crop and pasture/grass lands. Figures 6.3 and 6.4 show simulated TN and TP loadings by sub-watershed under existing BMPs condition. These loading also represents average annual loading for 21 years $(1990$ - 2011). The estimated loading from all land use categories including point sources and all sub-watersheds was 5,830,399 pounds TN and 375,421 pounds $\mathrm{TP}$ per year. The existing BMPs reduce $5 \%$ and $15 \%$ of total $\mathrm{TN}$ and $\mathrm{TP}$ loadings respectively. 


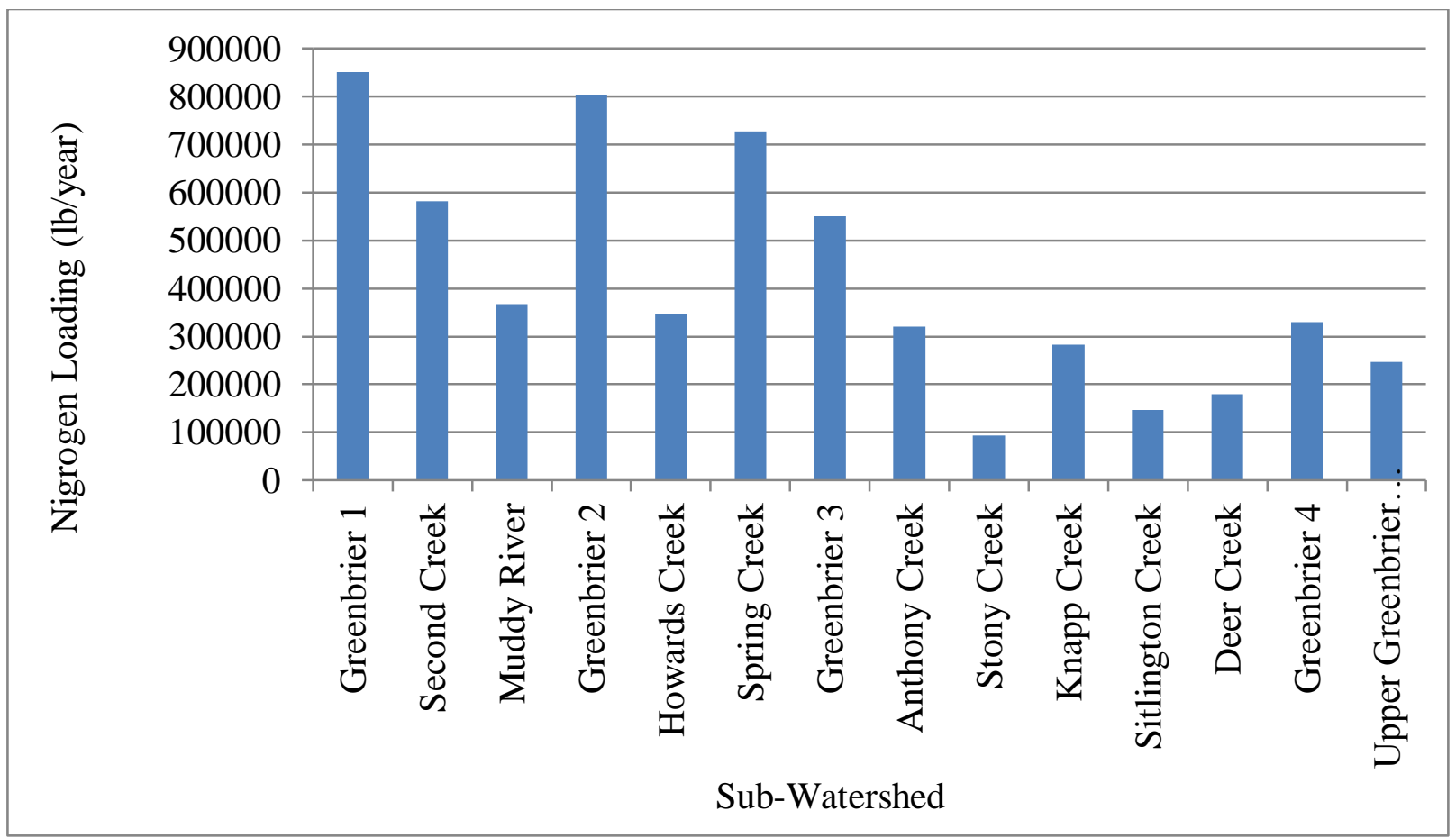

Figure 6.3: Sub-Watershed Level Nitrogen Loadings under Existing BMP Condition

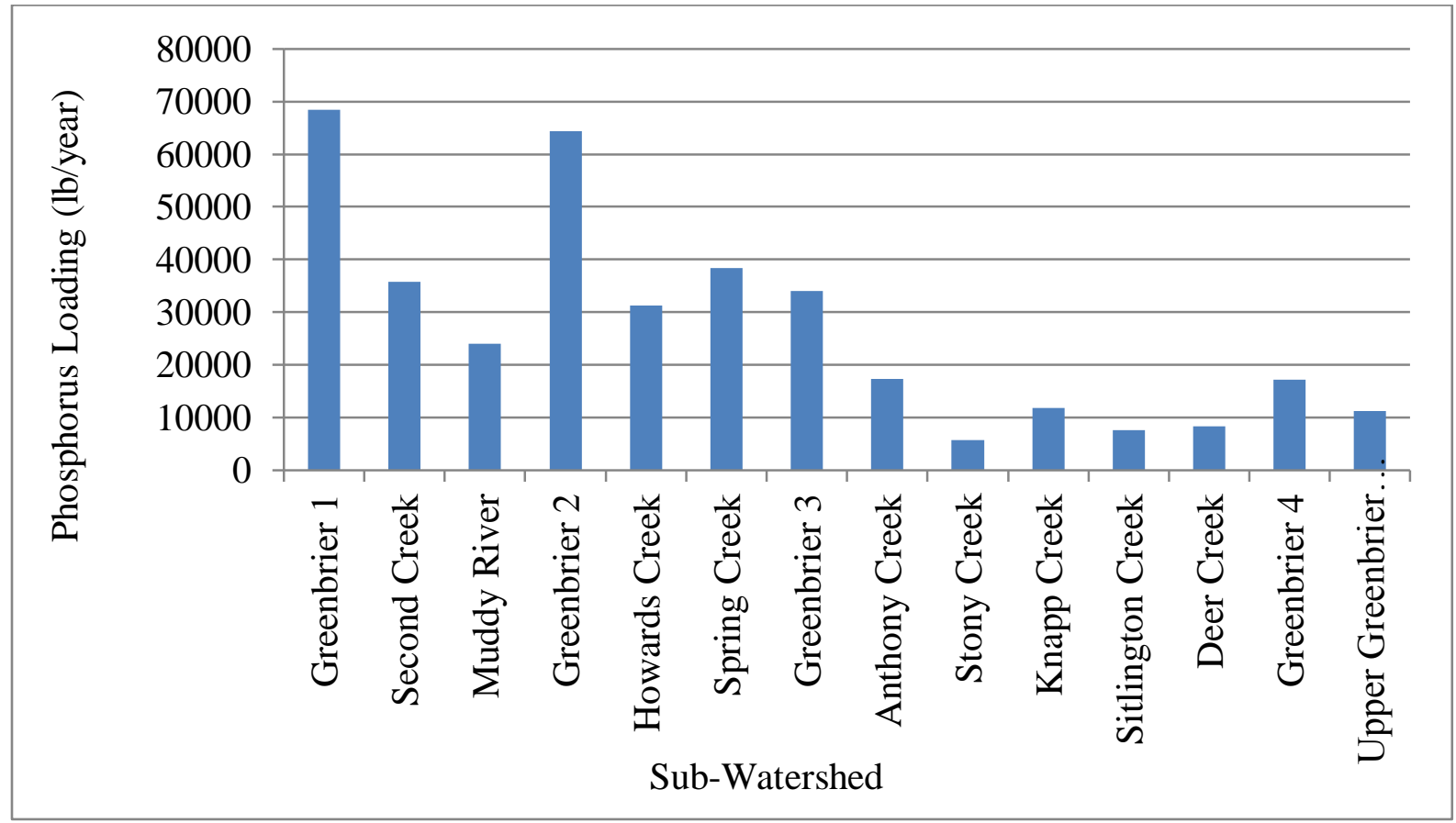

Figure 6.4: Sub-Watershed Level Phosphorus Loadings under Existing BMP condition

All significant point source dischargers are located in the lower portions of the Greenbrier River. WWTPs in Pence Springs and Union Town are located in Greenbrier 1 and 
Second Creeks. Town of Alderson and City of Ronceverte discharge in the Greenbrier 2 subwatershed. The City of White Sulfur Springs is located in Howards Creek sub-watershed. Town of Hillsboro and City of Marlinton are located in the middle of the Greenbrier River watershed.

The MapShed model also estimates nutrient concentration (mg/l) in the streams. Figures 6.5 and 6.6 show the spatial distribution of nitrogen and phosphorus concentration $(\mathrm{mg} / \mathrm{l})$ in the streamflow in the Greenbrier River watershed. Results indicate a direct relationship between amount of nutrient loadings and level of nutrient concentrations at the sub-watershed level. High $\mathrm{N}$ and $\mathrm{P}$ concentrations were found in the watershed with large areas under crop production and pasture/grasslands.

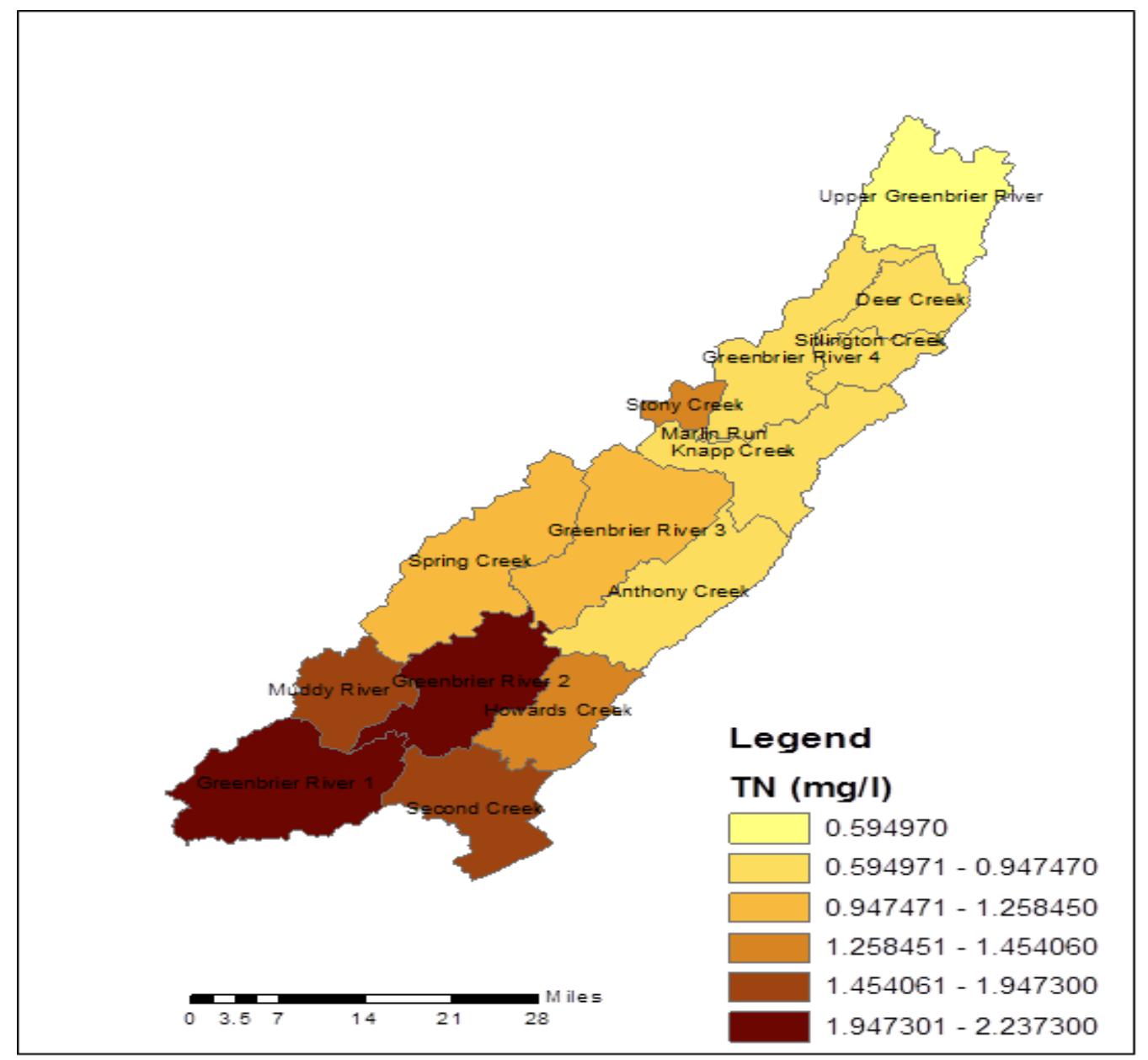

Figure 6.5: Sub-Watershed Level Nitrogen Concentration (mg/l) in the Streamflow 


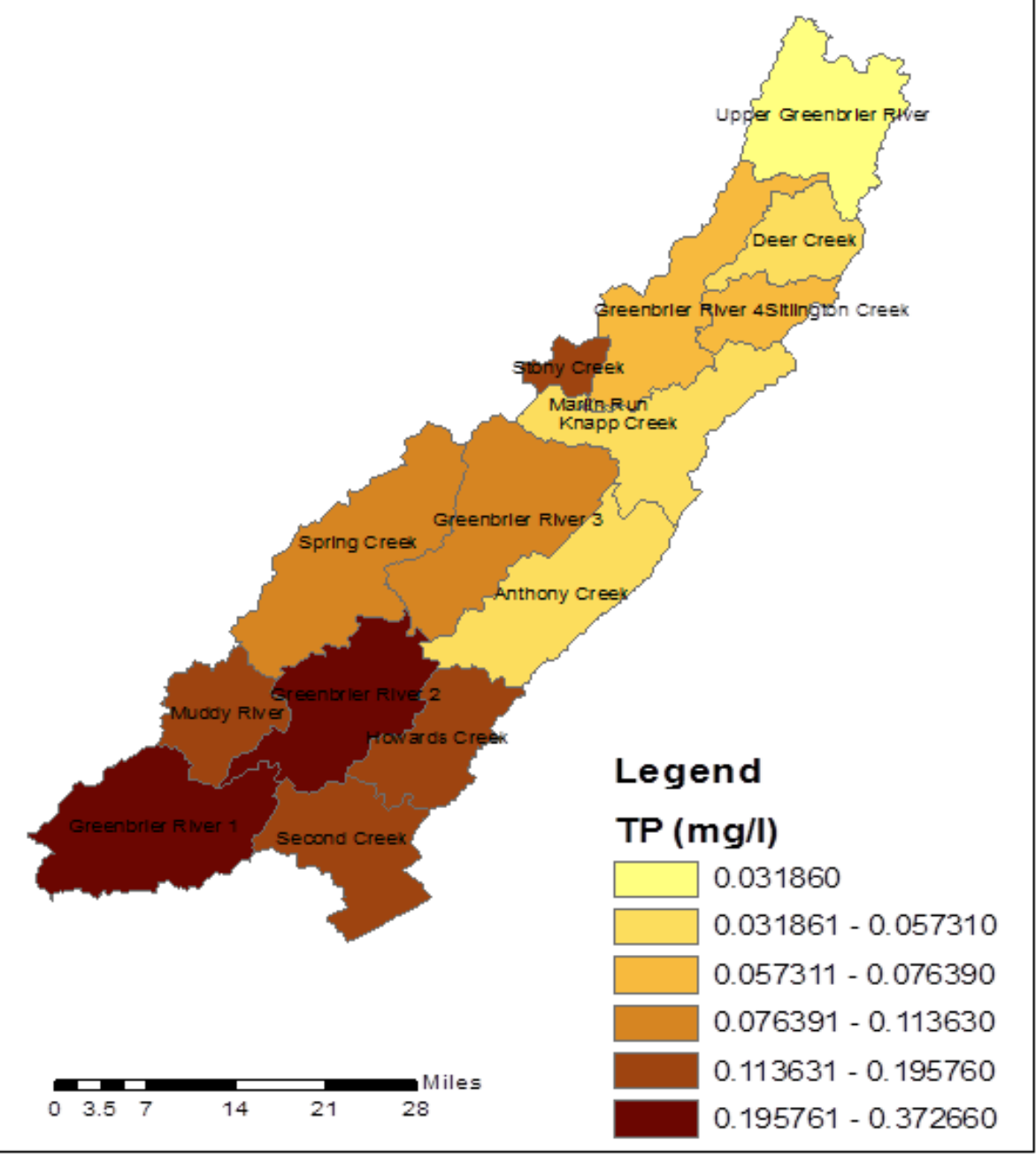

Figure 6.6: Sub-Watershed Level Phosphorus Concentration (mg/l) in the Stream flow

Figures 6.7 and 6.8 display the sub-watershed level nitrogen and phosphorus loading from land areas under crop production and pasture/grasslands. The estimated cumulative agricultural loading from crop and pasture/grasslands was 1,816,144 pounds of TN and 250,553 pounds of TP per year. The total amount of TN and TP discharges from the agricultural sources represents about $29 \%$ of total nitrogen and $56 \%$ of total phosphorus discharges in the watershed. The remaining discharges come from the forest lands, wetlands, and groundwater sources. Greenbrier 2 had the highest nutrient loadings, followed by Greenbrier 1 and Spring Creek. Second Creek, Greenbrier 3, Muddy River, and Howards Creek also indicate high N and P 
loadings from the crop, pasture and grasslands. The results are consistent with total nutrients loadings from each sub-watershed and nutrient loadings from crop and pasture/grasslands.

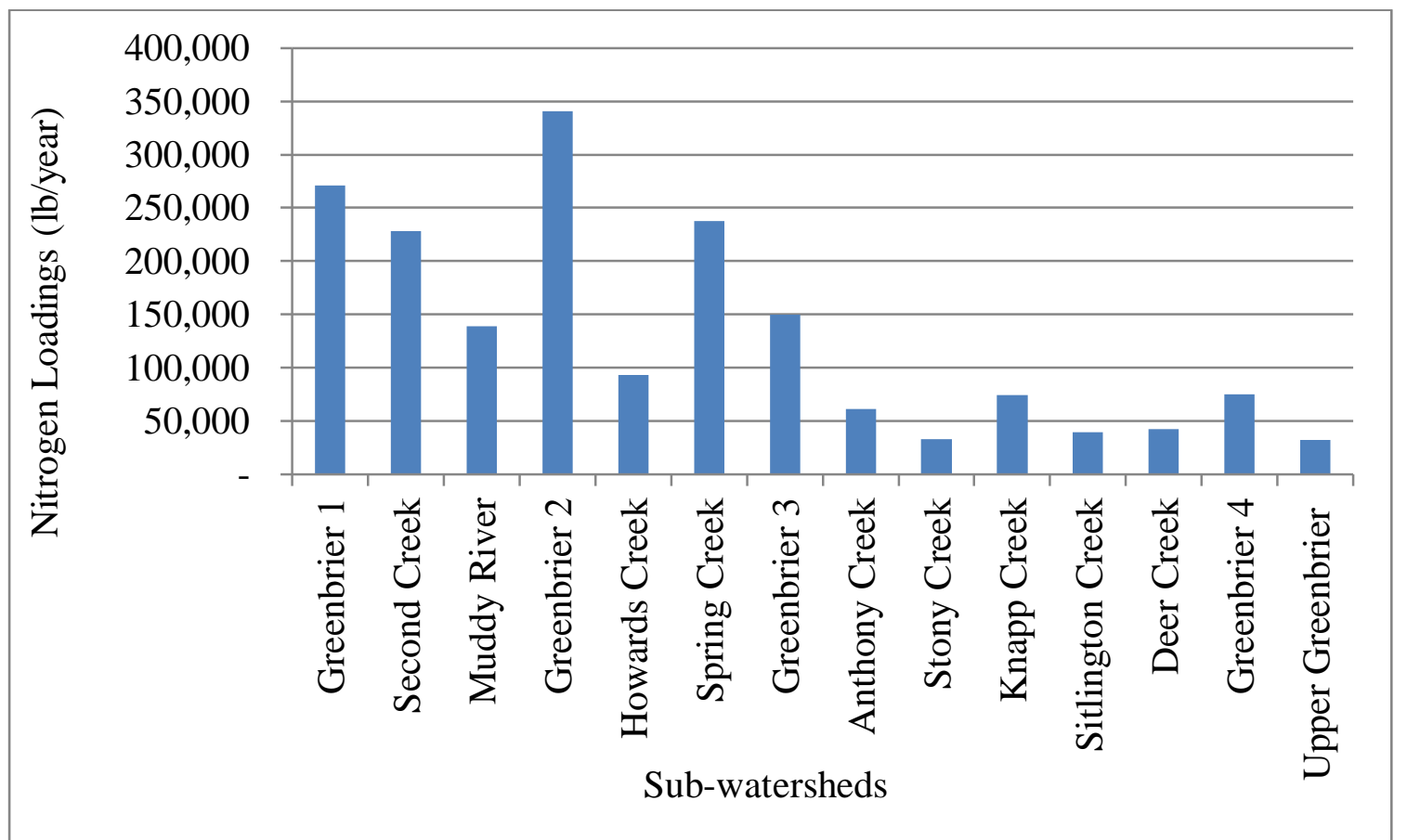

Figure 6.7: Sub-watershed Level Nitrogen Loadings from Crop and Pasture/Grasslands

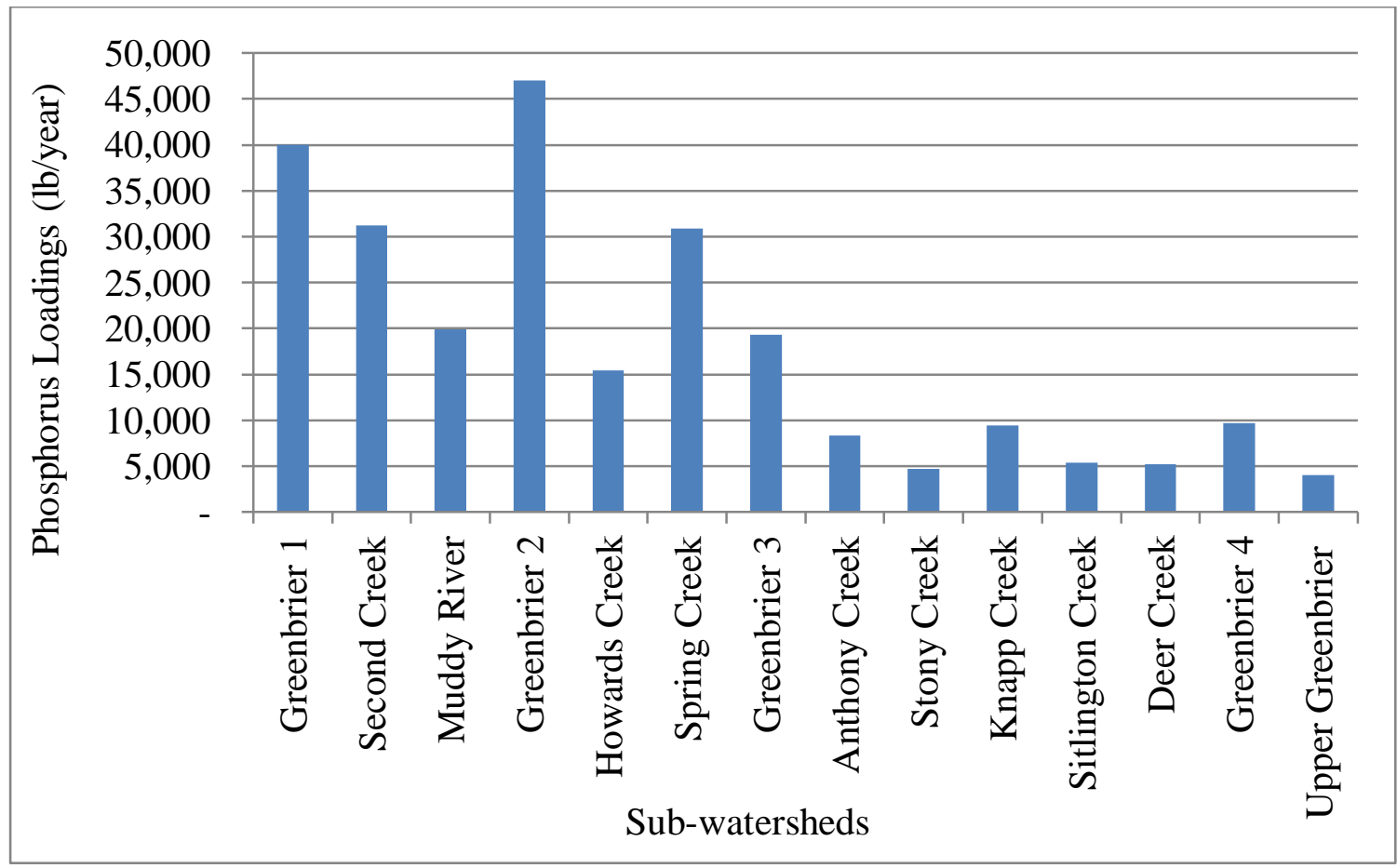

Figure 6.8: Sub-watershed Level Phosphorus Loadings from Crop and Pasture/Grasslands 
Table 6.10 presents estimated per acre nutrients discharge (lb/acre) from agricultural lands in each sub-watershed under without BMPs condition. Howards Creek had highest lb/acre TN and TP discharges from the pasture/grassland, followed by Anthony Creek. The highest TN and TP discharges from crop land were found in Greenbrier 1, followed by Second Creek. Average per acre TN and TP discharges for pasture/grassland were $7.61 \mathrm{lb} / \mathrm{acre}$ and $1.03 \mathrm{lb} / \mathrm{acre}$. Similarly, average per acre TN and TP discharges for crop land were 12.99 lb/acre and 2.64 lb/acre. Results are consistent with the fertilizer application rate in crop production and pasture/grazing lands if all farmers are applying recommended fertilizer application rate of nitrogen and phosphorus (160:50). Variations in TN and TP discharges among sub-watersheds resulted due to the difference in soil characteristics and physiography.

Table 6.10: Estimated Per Acre Nutrients Discharge from the Agricultural Lands in the SubWatersheds of Greenbrier River Watershed

\begin{tabular}{lcccc}
\hline \multirow{2}{*}{ Watershed } & \multicolumn{2}{c}{ Hay/pasture/grassland } & \multicolumn{2}{c}{ Crop land } \\
\cline { 2 - 5 } & TN (lb/acre.) & TP (lb/acre) & TN (lb/acre.) & TP (lb/acre) \\
\hline Greenbrier 1 & 7.87 & 1.13 & 25.38 & 6.62 \\
Second Creek & 7.25 & 0.96 & 13.62 & 3.14 \\
Muddy River & 7.68 & 1.09 & 13.32 & 2.95 \\
Greenbrier 2 & 7.17 & 0.97 & 10.33 & 2.14 \\
Howards Creek & 8.93 & 1.48 & 13.74 & 2.73 \\
Spring Creek & 7.18 & 0.93 & 10.93 & 2.10 \\
Greenbrier 3 & 7.22 & 0.90 & 11.23 & 2.06 \\
Anthony Creek & 8.06 & 1.10 & 10.73 & 1.81 \\
Stony Creek & 7.87 & 1.12 & 10.29 & 1.85 \\
Knapp Creek & 7.37 & 0.93 & 12.98 & 2.43 \\
Sitlington Creek & 7.80 & 1.06 & 11.74 & 2.17 \\
Deer Creek & 7.14 & 0.87 & 12.81 & 2.45 \\
Greenbrier 4 & 7.51 & 0.97 & 11.74 & 2.13 \\
Upper Greenbrier & 7.39 & 0.92 & 13.07 & 2.37 \\
\hline Average & 7.61 & 1.03 & 12.99 & 2.64 \\
\hline
\end{tabular}


The water quality model also predicted nutrients reduction from the implementation of BMPs on the crop and pasture/grassland. The PRedICT tool in the MapShed provided the estimated load reductions from the implementation of particular BMP. The average percentage of land under cover crop, nutrient management plan (crop land), nutrient management plan (pasture/grassland), and prescribed grazing were estimated based of farm BMPs survey. Survey results showed the following level of existing BMPs: Cover Crop (15\%), Nutrient Management Plan- Pasture and Grassland (17\%), Nutrient Management Plan- Cropland (24\%), Grazing Land Management (10\%). Figure 6.9 presents the amount of TN and TP reductions at the subwatershed level. Greenbrier 2 has the highest TN and TP load reductions. Greenbrier 1, Spring Creek, Second Creek, and Greenbrier 3 also reduces large amount of TN and TP from the existing BMPs.

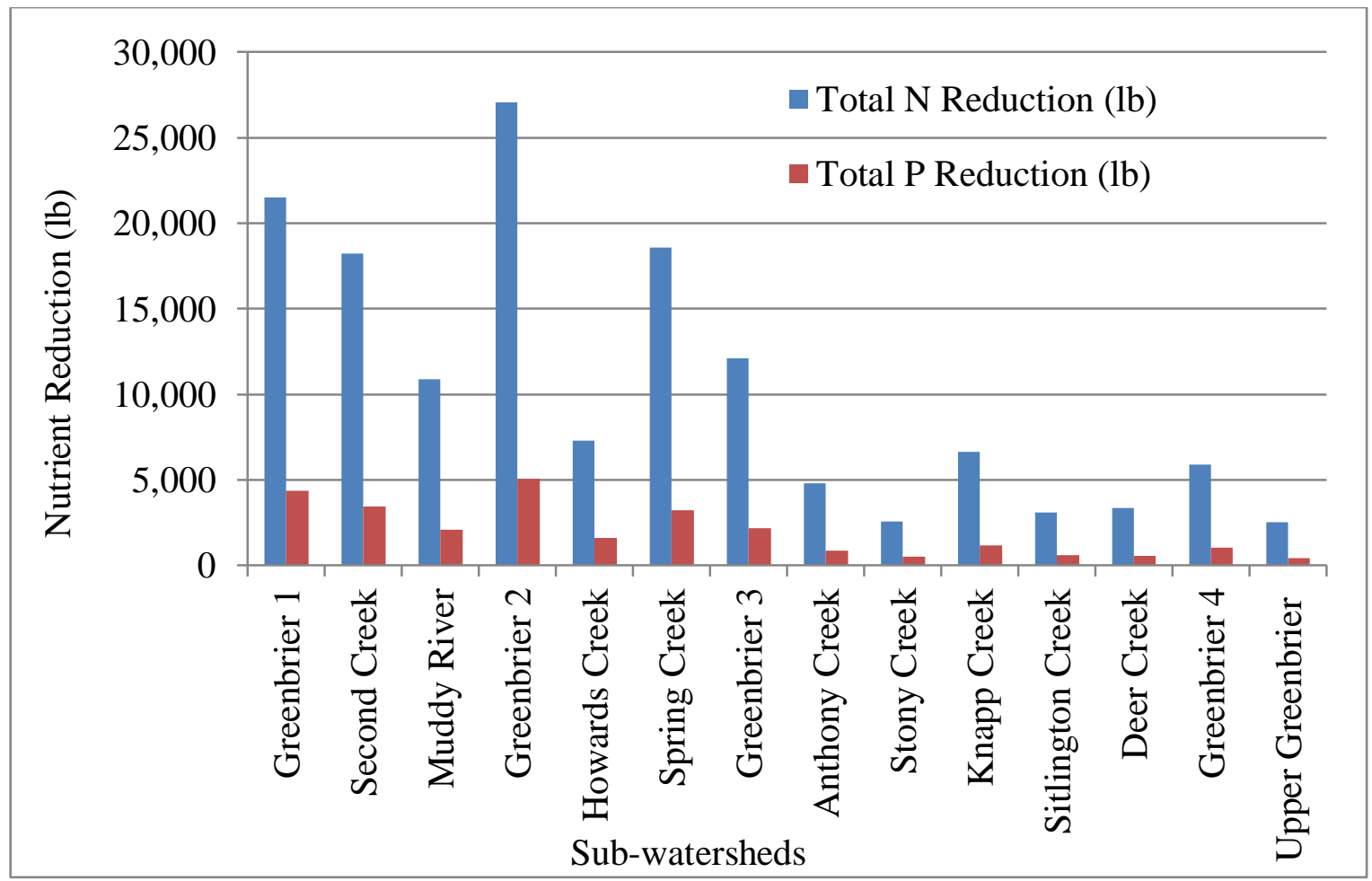

Figure 6.9: Estimated TN and TP Reduction from the Existing BMPs in the Agricultural Lands 
Total annual nutrient discharges from point sources in the Greenbrier River watershed were estimated from the EPA's latest discharger monitoring report (EPA 2010). Table 6.11 presents estimated exiting nutrient loads from the permitted NPDES facilities (WWTPs) in the Greenbrier River watershed. Union PSD discharges the highest amount of TN, followed by WWTP in the city of Ronceverte. The City of Ronceverte and the Union PSD discharge high amount of total phosphorus.

Table 6.11: Estimated Existing Nutrient Loads from the Permitted NPDES Facilities in the Greenbrier Watershed

\begin{tabular}{lcccc}
\hline \multirow{2}{*}{\begin{tabular}{l} 
Wastewater Treatment Plants \\
\cline { 2 - 5 }
\end{tabular}} & \multicolumn{2}{c}{ Total Nitrogen } & \multicolumn{2}{c}{ Total Phosphorus } \\
\cline { 2 - 5 } & $\begin{array}{c}\text { Daily load } \\
\text { (lbs/day) }\end{array}$ & $\begin{array}{c}\text { Annual load } \\
(\mathrm{lbs})\end{array}$ & $\begin{array}{c}\text { Daily load } \\
\text { (lbs/day) }\end{array}$ & $\begin{array}{c}\text { Annual load } \\
(\text { lbs })\end{array}$ \\
\hline Town of Alderson & 25.23 & 9,209 & 7.62 & 2,783 \\
City of Ronceverte & 143.45 & 52,359 & 36.52 & 13,332 \\
Union PSD & 268.96 & 98,170 & 32.27 & 11,780 \\
Pence Springs & 32.56 & 11,883 & 16.08 & 5,872 \\
City of White Sulfur Springs & 82.99 & 30,291 & 18.67 & 6,815 \\
Town of Hillsboro & 5.28 & 1,926 & 3.41 & 1,247 \\
City of Marlinton & 25.05 & 9,126 & 3.21 & 1,172 \\
\hline Total & 583.52 & 212,985 & 117.78 & 43,001 \\
\hline
\end{tabular}

\subsection{POTENTIAL NUTRIENT CREDIT DEMAND}

\subsubsection{NUTRIENT LOAD REDUCTION REQUIREMENT}

The total annual amount of nutrient load reduction requirement for each WWTP in the Greenbrier River watershed was estimated based on their current level of discharge and likely future effluent limits. Table 6.12 summarizes the changes in pollutant loads for TN and TP under different nutrient limits for nitrogen and phosphorus. The factors that affect TN and TP reduction requirements were facilities actual flows (MGD), nutrient concentration (mg/l), and daily discharge amount (lb./day). Results show that larger facilities with high level of nutrient concentrations in their discharges had higher load reduction requirements under more stringent 
effluent limitation. The City of Ronceverte had the highest TN and TP reduction requirement at all effluent limits. The Town of Hillsboro had low TN reduction requirement whereas the Union PDS had the lowest TP reduction requirement. Nitrogen concentration in the discharge of the City of White Sulfur Springs in 2010 was below $8 \mathrm{mg} / \mathrm{l}$. Thus, this facility does not require TN reduction at $8 \mathrm{mg} / \mathrm{l} \mathrm{TN}$ limit.

Table 6.12: Estimated Nutrient Loads Reduction Requirements for Permitted NPDES Facilities in the Greenbrier Watershed

\begin{tabular}{lcccccc}
\hline \multirow{2}{*}{ Facility } & \multicolumn{3}{c}{ Total Nitrogen (lb.) } & \multicolumn{3}{c}{ Total Phosphorus (lb.) } \\
\cline { 2 - 7 }$@$ Town of Alderson & 2,262 & 3,117 & 5,554 & 1,930 & 2,357 & 2,698 \\
City of Ronceverte & 28,722 & 37,586 & 43,495 & 6,024 & 7,502 & 8,684 \\
Union PSD & 3,153 & 3,884 & 4,372 & 486 & 608 & 706 \\
Pence Springs & 186 & 4,572 & 7,496 & 4,410 & 5,141 & 5,726 \\
City of White & & & & & & \\
Sulfur Springs & 0 & 10,340 & 18,320 & 2,824 & 4,819 & 6,416 \\
Town of Hillsboro & 367 & 951 & 1,341 & 1,052 & 1,149 & 1,227 \\
City of Marlinton & 4,026 & 5,945 & 7,224 & 532 & 852 & 1,108 \\
\hline Total & 38,715 & 66,395 & 87,803 & 17,259 & 22,428 & 26,563 \\
\hline
\end{tabular}

Table 6.13 breaks down the estimated TN and TP loads reduction requirements from Table 27 by sub-watershed level. The highest reduction requirement for both TN and TP was found in the Greenbrier 2 sub-watershed. Greenbrier 1 and Howards Creek also had high nutrient reduction requirement from the WWTPs. Greenbrier 3 sub-watershed had the lowest amount of TN reduction requirement. Similarly, Greenbrier 4 sub-watershed had the lowest amount of TP reduction requirement. The agricultural source discharge contributes large proportion of total loadings in all of these sub-watersheds. 
Table 6.13: Estimated Nutrient Loads Reduction Requirements for Permitted NPDES Facilities at Sub-Watershed Level

\begin{tabular}{lcccccc}
\hline & \multicolumn{3}{c}{ Total Nitrogen (lb.) } & \multicolumn{3}{c}{ Total Phosphorus (lb.) } \\
\cline { 2 - 7 } Facility & $@ 8 \mathrm{mg} / 1$ & $@ 5 \mathrm{mg} / 1$ & $@ 3 \mathrm{mg} / 1$ & $@ 1 \mathrm{mg} / \mathrm{l}$ & $@ 0.5 \mathrm{mg} / 1$ & $@ 0.1 \mathrm{mg} / 1$ \\
\hline Greenbrier 1 & 3,339 & 8,456 & 11,868 & 4,896 & 5,749 & 6,432 \\
Muddy River & 2,262 & 3,117 & 5,554 & 1,930 & 2,357 & 2,698 \\
Greenbrier 2 & 28,722 & 37,586 & 43,495 & 6,024 & 7,502 & 8,684 \\
Howards Creek & 0 & 10,340 & 18,320 & 2,824 & 4,819 & 6,416 \\
Greenbrier 3 & 367 & 951 & 1,341 & 1,052 & 1,149 & 1,227 \\
Greenbrier 4 & 4,026 & 5,945 & 7,224 & 532 & 852 & 1,108 \\
\hline Total & 38,715 & 66,395 & 87,803 & 17,259 & 22,428 & 26,563 \\
\hline
\end{tabular}

\subsubsection{COSTS FOR NUTRIENT REDUCTION}

Detail nutrient reduction cost estimates for individual WWTP are presented in Appendix B. These cost estimates represent annualized total capital and O\&M costs for each facility. Per unit $\operatorname{costs}(\$ / \mathrm{lb}$.) of TN and TP reductions were calculated based on total annual cost of facility upgrades and TN and TP reduction requirements for each facility. The estimated total annual costs of plant upgrades for each WWTP in a single nutrient reduction scenario are presented in Table 6.14. The annual costs of upgrade to meet nitrogen limitations are range from $\$ 216,045$ to $\$ 909,852$ million. Similarly, the annual costs of upgrade to meet phosphorus limitations are range from $\$ 173,299$ to $\$ 1,463,947$.

Table 6.14: Estimated Nutrient Reduction Costs for WWTPs in a Single Nutrient Standard

\begin{tabular}{lcccccc}
\hline \multirow{2}{*}{ WWTP } & \multicolumn{3}{c}{ Total Annual Cost of TN Reduction (\$) } & \multicolumn{3}{c}{ Total Annual Cost of TP Reduction (\$) } \\
\cline { 2 - 7 } & TN 8mg/l & TN 5mg/l & TN 3mg/l & TP 1mg/l & TP 0.5mg/l & TP 0.1mg/l \\
\hline Town of Alderson & 245,015 & 310,892 & 412,595 & 202,061 & 253,507 & 510,667 \\
City of Ronceverte & 380,393 & 551,991 & 831,036 & 322,859 & 470,246 & $1,113,949$ \\
Union PSD & 384,190 & 579,803 & 909,852 & 374,706 & 533,265 & $1,463,947$ \\
Pence Springs & 234,919 & 312,259 & 430,592 & 194,053 & 254,120 & 544,678 \\
City of White & & & & & & \\
Sulfur Springs & 356,984 & 524,617 & 794,591 & 316,700 & 456,441 & $1,099,483$ \\
Town of Hillsboro & 216,045 & 242,316 & 290,455 & 173,299 & 192,616 & 280,555 \\
City of Marlinton & 251,961 & 316,699 & 403,703 & 214,337 & 272,059 & 482,372 \\
\hline Total & $2,069,507$ & $2,838,577$ & $4,072,824$ & $1,798,015$ & $2,432,254$ & $5,495,651$ \\
\hline
\end{tabular}


Table 6.15 presents the estimated total annual costs of plant upgrades for each WWTP under combined nutrient standards where both TN and TP are regulated. Total annual costs of a treatment plant upgrade increases to meet two nutrients limit in the combined nutrient market. However, total cost of compliance to meet TP standard decreases in the combined nutrient market. This reduction is due to the total annual capital cost of treatment plant upgrades being proportionally distributed to both TN and TP reduction costs. The proportion of TP inflow in all treatment plant was lower than the proportion of TP inflow.

Table 6.15: Estimated Nutrient Reduction Costs for WWTPs with a Combined Nutrient Standard

\begin{tabular}{lrrr}
\hline \multirow{2}{*}{ WWTP } & \multicolumn{3}{c}{ Total Annual Cost of TP and TN Reduction (\$) } \\
\cline { 2 - 4 } & $\begin{array}{c}8 \mathrm{mg} / \mathrm{l} \text { of TN and } \\
1 \mathrm{mg} / \mathrm{l} \text { of TP }\end{array}$ & $\begin{array}{c}5 \mathrm{mg} / \mathrm{l} \text { of TN and } \\
0.5 \mathrm{mg} / \mathrm{l} \text { of TP }\end{array}$ & $\begin{array}{c}3 \mathrm{mg} / \mathrm{l} \text { of TN and } \\
0.1 \mathrm{mg} / 1 \text { of TP }\end{array}$ \\
\hline Town of Alderson & 262,934 & 331,558 & 633,292 \\
City of Ronceverte & 417,887 & 597,962 & $1,310,802$ \\
Union PSD & 468,296 & 680,564 & $1,724,668$ \\
Pence Springs & 251,816 & 332,463 & 675,372 \\
City of White Sulfur Springs & 402,498 & 579,045 & $1,300,296$ \\
Town of Hillsboro & 226,721 & 253,309 & 364,862 \\
City of Marlinton & 276,746 & 343,008 & 574,960 \\
\hline Total & $2,306,898$ & $3,117,909$ & $6,584,252$ \\
\hline
\end{tabular}

The estimated costs in Tables 6.14 and 6.15 are estimated total additional costs to achieve the load reduction requirement at different effluent limits. Table 6.16 summarizes the average additional costs per unit (pound of nutrient reduced) calculations for all facilities operating in a single TN or TP nutrient trading market. Per unit costs were directly related to the size of facility, TN and $\mathrm{TP}$ concentrations, and amount of $\mathrm{TN}$ and $\mathrm{TP}$ reduction requirements. Average per unit cost of TN reduction was highest for the Pence Spring at $8 \mathrm{mg} / \mathrm{l} \mathrm{TN}$ limit $(\$ 1,264 / \mathrm{lb}$. $)$, followed by the Town of Hillsboro $(\$ 589 / \mathrm{lb}$.). Union PDS and the Town of Hillsboro had the highest per unit costs of TN reduction at $5 \mathrm{mg} / \mathrm{l}$ and $3 \mathrm{mg} / \mathrm{l} \mathrm{TN}$ limits. The Union PSD and the City of Marlinton had high per unit costs of TP reductions at all levels of TP limits. For majority 
of WWTPs, per unit costs of TN reductions were low at more stringent TN limits. The total operational costs for $\mathrm{TN}$ reduction decreases as the WWTPs need to comply with more stringent TN limits. But the operational costs for TP reduction increases as the WWTPs need to comply with more stringent TP limits. Thus, per unit costs of TP reductions were high at more stringent TP limits for all WWTPs.

Table 6.16: Average Per Unit Cost (\$/lb) of Additional Nutrient Reductions Required for WWTPs to Meet Different Nutrient Limits in a Single (TN or TP) Nutrient Trading Market

\begin{tabular}{lcccccc}
\hline \multirow{2}{*}{ Facility } & \multicolumn{3}{c}{ Total Nitrogen $(\$ / \mathrm{lb})$} & \multicolumn{3}{c}{ Total Phosphorus $(\$ / \mathrm{lb})$} \\
\cline { 2 - 7 } & $@ 8 \mathrm{mg} / 1$ & $@ 5 \mathrm{mg} / 1$ & $@ 3 \mathrm{mg} / 1$ & $@ 1 \mathrm{mg} / 1$ & $@ 0.5 \mathrm{mg} / 1$ & $@ 0.1 \mathrm{mg} / 1$ \\
\hline Town of Alderson & 108.33 & 99.75 & 74.29 & 104.68 & 107.57 & 189.29 \\
City of Ronceverte & 13.24 & 14.69 & 19.11 & 53.59 & 62.69 & 128.28 \\
Union PSD & 121.84 & 149.27 & 208.13 & 770.50 & 876.85 & $2,074.6$ \\
Pence Springs & $1,264.07$ & 68.3 & 57.44 & 44.00 & 49.43 & 95.13 \\
City of White Sulfur & - & 50.74 & 43.37 & 112.14 & 94.71 & 171.38 \\
Springs & & & & & & \\
Town of Hillsboro & 589.23 & 254.67 & 216.53 & 164.75 & 167.58 & 228.59 \\
City of Marlinton & 62.59 & 53.27 & 55.88 & 402.91 & 319.39 & 435.48 \\
\hline
\end{tabular}

Note: TN concentration in the discharge of the City of White Sulfur Spring was below $8 \mathrm{mg} / \mathrm{l}$

Table 6.17 summarizes the average per unit cost estimates for all WWTPs in a combined TN and TP nutrient trading market. Average per unit costs of TN and TP reduction were significantly lower for the combine nutrients reduction from all the WWTPs. In the combined nutrient trading market, the average per unit cost of TP reduction was reduced significantly compared to the average per unit costs of TN reduction. 
Table 6.17: Average Per Unit Cost (\$/lb) of Nutrient Reduction for WWTPs to Meet Different Nutrient Limits in Combined (TN and TP) Nutrients Trading Market

\begin{tabular}{lcccccc}
\hline \multirow{2}{*}{ Facility } & \multicolumn{3}{c}{ Total Nitrogen $(\$ / \mathrm{lb})$} & \multicolumn{3}{c}{ Total Phosphorus $(\$ / \mathrm{lb})$} \\
\cline { 2 - 7 } & $@ 8 \mathrm{mg} / \mathrm{l}$ & $@ 5 \mathrm{mg} / 1$ & $@ 3 \mathrm{mg} / \mathrm{l}$ & $@ 1 \mathrm{mg} / \mathrm{l}$ & $@ 0.5 \mathrm{mg} / \mathrm{l}$ & $@ 0.1 \mathrm{mg} / \mathrm{l}$ \\
\hline Town of Alderson & 95.31 & 87.79 & 65.94 & 24.55 & 24.58 & 99 \\
City of Ronceverte & 11.85 & 13.11 & 17.07 & 12.86 & 14.05 & 65.47 \\
Union PSD & 110.78 & 135.91 & 190.31 & 244.65 & 251.02 & $1,265.12$ \\
Pence Springs & $1,073.42$ & 58.06 & 49.44 & 11.87 & 13.03 & 53.23 \\
City of White Sulfur Springs & - & 41.8 & 35.92 & 38.2 & 30.48 & 100.11 \\
Town of Hillsboro & 531.57 & 229.85 & 196.55 & 30.25 & 30.11 & 82.46 \\
City of Marlinton & 56.46 & 47.9 & 50.28 & 92.91 & 68.39 & 191.12 \\
\hline
\end{tabular}

The above cost estimates assumed linear cost function for all WWTPs and the average cost of TN and TP reduction represent maximum WTP for each treatment plant. In the actual WQT market, each WWTP will seek to minimize their total cost of nutrient reduction at the particular effluent limit established by regulatory authority.

\subsubsection{POTENTIAL NUTRIENT CREDIT DEMAND}

Potential nutrient credit demand for each WWTP in the Greenbrier River watershed was estimated based on the current level of discharge and likely future effluent limits. The amount of TN and TP reduction requirement to meet likely future effluent limits for each facility was considered as the potential credit demand for that facility. Figure 6.10 presents aggregate demand curves for TP credits at different TP limits in the watershed. This figure shows that the more stringent TP limits shift the potential demand curve outward thereby increasing WTP for TP credits by the WWTPs. 


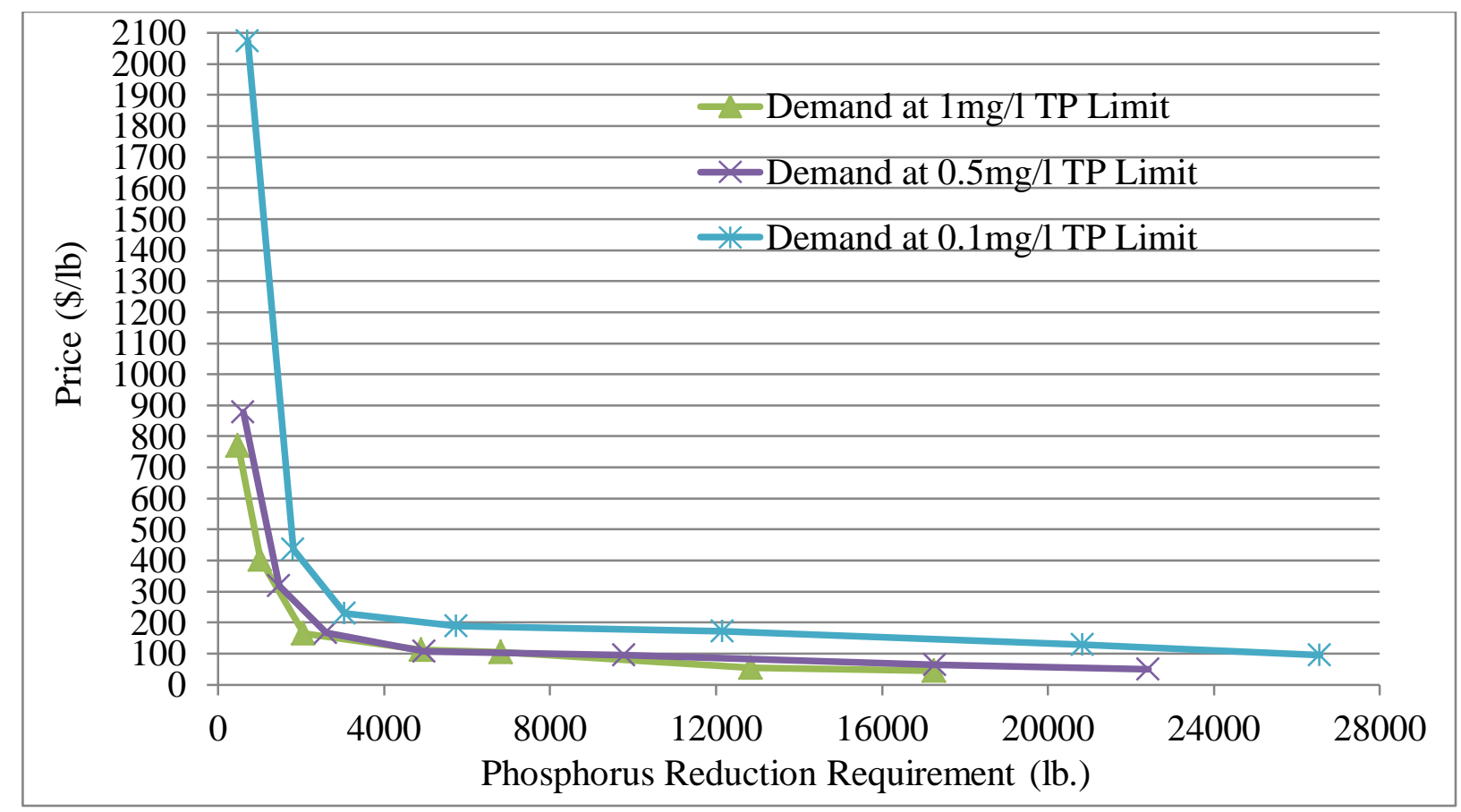

Figure 6.10: Potential TP Credit Demand by WWTPs at Different TP limits in the Greenbrier River Watershed

Figure 6.11 shows the aggregate demand for $\mathrm{TN}$ credits at different $\mathrm{TN}$ limits in the watershed. This figure indicates that some WWTPs would purchase TN credits at very high prices in the WQT market at 8mg/1 TN limit.

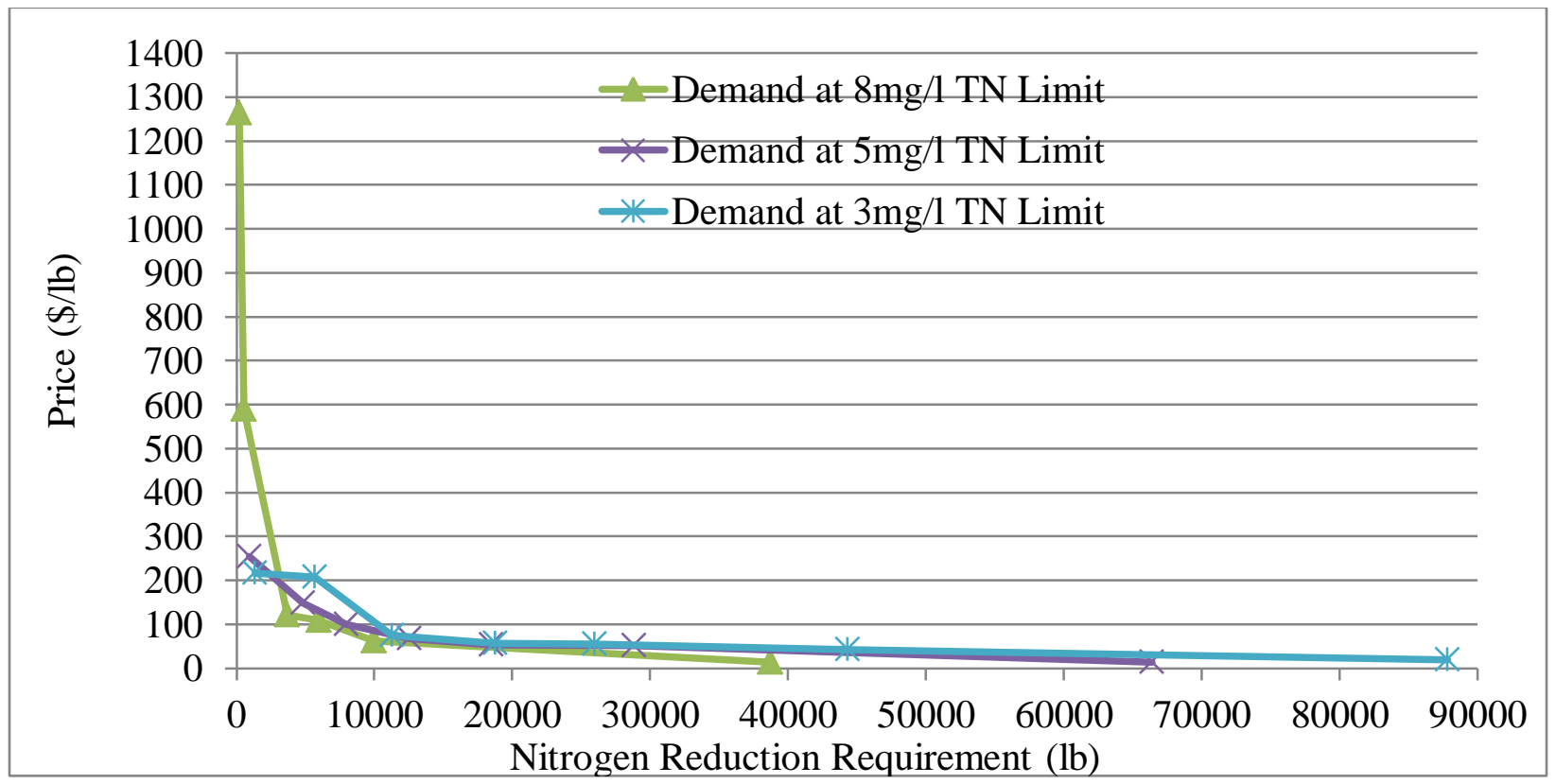

Figure 6.11: Potential TN Credit Demand by WWTPs at Different TN limits in the Greenbrier River Watershed 
The cost of TN reduction was very high for some WWTPs with low TN concentration at their current dischage levels. The aggregate potential demand for TN shifts outward only slightly for more stringent TN limits.

\subsection{POTENTIAL NUTRIENTS CREDIT SUPPLY}

Potential TN and TP credits supplied from agricultural sources were estimated based on the simulation of water quality model in the MapShed. The PRedICT tool in the Mapshed was used to simulate different BMP scenarios. All total 12 different nutrient credit supply scenarios (Table 5.5) were simulated for each sub-watershed. Each simulation estimates required the level of particular BMP to meet WWTP's total TN and TP reduction requirements in the watershed. The BMP that can generate nutrient credits at the lowest per unit cost (\$/lb.) was allowed first in the simulation process. If $100 \%$ coverage of cheapest BMP did not fulfill total nutrients reduction requirements of particular scenario, then the second lowest cost BMP was computed. The proportion of $\mathrm{TN}$ reduction from the BMPs was high compared to the proportion of $\mathrm{TP}$ reduction. Thus, each simulation targeted meeting the WWTP's TP reduction requirements. The WWTP's TN reduction requirements were automatically fulfilled when TP reduction requirements were meet. Table 6.18 presents the total pasture and crop lands in each subwatershed of the Greenbrier River watershed. The sub-watershed 1, 2, 4, and 6 has more than 30,000 acres of pasture lands and 200 acres of crop land. The Greenbrier River watershed includes 236,428 acres of pasture land and 3,704 acres of crop land. 
Table 6.18: Total Pasture and Crop Lands in each Sub-Watershed of Greenbrier River Basin

\begin{tabular}{lcc}
\hline Watershed & Pasture land (acres) & Crop land (acres) \\
\hline 1 & 33,246 & 361 \\
2 & 30,223 & 675 \\
3 & 17,851 & 131 \\
4 & 46,073 & 1,030 \\
5 & 10,369 & 37 \\
6 & 32,746 & 220 \\
7 & 19,462 & 840 \\
8 & 7,561 & 25 \\
9 & 4,183 & 15 \\
10 & 9,879 & 89 \\
11 & 4,885 & 99 \\
12 & 5,824 & 62 \\
13 & 9,808 & 104 \\
14 & 4,317 & 17 \\
\hline Total & 236,428 & 3,704 \\
\hline
\end{tabular}

\subsubsection{BASELINE: EXISTING LEVEL OF BMPS}

This section presents the simulation results considering existing BMPs as a baseline for agricultural sources. The farm BMPs survey showed that $15 \%$ cover crop and $24 \%$ nutrient management plan on the crop lands, and 10\% prescribed grazing and 17\% nutrient management plan on the pasture/grass lands in the study area. Putting these levels of BMPs as a baseline, TN and TP supply from the agricultural sources were simulated. TN and TP credits supply for individual trading scenario is discussed below:

Scenario 1: Trading Ratio (1:1), WWTP's Effluent Limit ( $8.0 \mathrm{mg} / \mathrm{l} \mathrm{TN}, 1.0 \mathrm{mg} / \mathrm{l} \mathrm{TP})$

The estimated total TP and TN reduction requirements for the WWTPs in the watershed under this scenario were $17,259 \mathrm{lb}$. and $38,715 \mathrm{lb}$. respectively. Nutrient management plan on crop land was simulated first to estimate the low cost TP and TN credits. Seventy five percent increases in nutrient management plan and $85 \%$ increase in cover crop on crop lands, and only $10 \%$ increase in nutrient management plan on the pasture/hay/grasslands beyond the existing 
level can meet TP and TN reduction requirements for the WWTPs under this scenario. The existing levels of nutrient management plan and cover crop on crop land and nutrient management plan on the pasture/hay/grasslands were $24 \%, 15 \%$ and $17 \%$ respectively. Farmers do not need to implement rotational grazing on pasture/grasslands to meet WWTP's TN and TP reduction requirements under this scenario. This BMP is expensive compared to the nutrient management plan and cover crop on crop lands and the nutrient management plan on pasture/grasslands. Table 6.19 summarizes the simulation results and presents the amounts of TN and TP credits generated from each sub-watershed.

Table 6.19: Potential Nutrient Credits Generation from Agricultural Sources to Meet WWTP Discharge Limits of $8 \mathrm{mg} / \mathrm{l} \mathrm{TN}$ and $1 \mathrm{mg} / 1 \mathrm{TP}$ at a 1:1 Trading Ratio

\begin{tabular}{lcccccccc}
\hline Watershed & \multicolumn{2}{c}{$\begin{array}{c}\text { Cover crop } \\
(85 \%)\end{array}$} & \multicolumn{2}{c}{$\begin{array}{c}\text { NMP-Crop land } \\
(76 \%)\end{array}$} & $\begin{array}{c}\text { NMP- Pasture/grassland } \\
(10 \%)\end{array}$ & \multicolumn{2}{c}{ Total } \\
\cline { 2 - 9 } & TN & TP & TN & TP & TN & TP & TN & TP \\
\hline Greenbrier 1 & 2,254 & 1,013 & 2,015 & 546 & 6,074 & 1,653 & 10,343 & 3,212 \\
Second Creek & 2,265 & 902 & 2,025 & 485 & 5,084 & 1,280 & 9,374 & 2,667 \\
Muddy River & 431 & 165 & 386 & 89 & 3,182 & 859 & 3,999 & 1,113 \\
Greenbrier 2 & 2,625 & 939 & 2,347 & 506 & 7,665 & 1,971 & 12,637 & 3,416 \\
Howards Creek & 123 & 42 & 110 & 23 & 2,148 & 674 & 2,381 & 739 \\
Spring Creek & 596 & 197 & 533 & 155 & 5,452 & 1,338 & 6,581 & 1,690 \\
Greenbrier 3 & 2,324 & 735 & 2,078 & 396 & 3,258 & 774 & 7,660 & 1,905 \\
Anthony Creek & 67 & 20 & 60 & 10 & 1,414 & 367 & 1,541 & 397 \\
Stony Creek & 37 & 11 & 33 & 6 & 763 & 207 & 833 & 224 \\
Knapp Creek & 281 & 91 & 252 & 49 & 845 & 243 & 1,378 & 383 \\
Sitlington Creek & 287 & 92 & 257 & 49 & 884 & 229 & 1,428 & 370 \\
Deer Creek & 199 & 66 & 178 & 35 & 964 & 223 & 1,341 & 324 \\
Greenbrier 4 & 304 & 96 & 272 & 51 & 1,708 & 419 & 2,284 & 566 \\
Upper Greenbrier & 56 & 18 & 50 & 9 & 740 & 226 & 846 & 253 \\
River & & & & & & & & \\
\hline Total & 11,849 & 4,387 & 10,596 & 2,409 & 40,181 & 10,463 & 62,626 & 17,259 \\
\hline
\end{tabular}

Cover crop on 3,150 acres of crop lands generates 11,849 pounds of $\mathrm{TN}$ credits and 4,387 pounds of TP credits. Nutrient management plan on 2,816 acres of crop lands produces 10,596 pounds of TN credits and 2,409 pounds of TP credits. Nutrient management plan on 23,643 acres 
of pasture/grassland produces 40,181 pounds of TN credits and 10,463 pounds of TP credits. Greenbrier 2, Greenbrier 1, and Second Creek supply large amount of TN and TP from the crop and pasture/grasslands. Four out of seven WWTPs are located in these three sub-watersheds. These four WWTPs require $88 \%$ and $74 \%$ of total TN and TP reduction, respectively.

Average costs of nutrient reduction from the BMPs on the crop and pasture/grass lands are presented in Table 6.20. Results show substantial cost variations among the sub-watersheds. For some of the WWTPs, the cost of nutrient credit generation from the nutrient management plan on the pasture/grassland was higher than the average per unit cost of additional nutrient reduction required complying. Nutrient management plan on the cropland can generate nutrient credits at lower cost than the average per unit cost of additional nutrient reduction from the other BMPs. Average per unit costs for TN and TP reduction from the nutrient management on the crop land were $\$ 6.69$ and $\$ 32.99$ in single nutrient market, respectively. This per unit costs for TN and TP reduction were reduced to $\$ 5.89$ and $\$ 3.96$ in combine nutrient market, respectively.

Table 6.20: Average per Unit Cost of Nutrient Reduction from BMPs for Crop and Pasture/Grasslands

\begin{tabular}{lcccc}
\hline & \multicolumn{2}{c}{ Single Nutrient Market } & \multicolumn{2}{c}{ Combined Nutrients Market } \\
\cline { 2 - 5 } BMP & $\mathrm{TN}(\$ / \mathrm{lb})$. & $\mathrm{TP}(\$ / \mathrm{lb})$. & $\mathrm{TN}(\$ / \mathrm{lb})$. & $\mathrm{TP}(\$ / \mathrm{lb})$. \\
\hline \multirow{2}{*}{ NMP - Crop land } & 6.69 & 32.99 & 5.89 & 3.96 \\
& $(3.27-8.08)$ & $(12.07-46.54)$ & $(2.88-7.11)$ & $(1.45-5.58)$ \\
Cover Crop & 12.23 & 36.75 & 10.76 & 4.41 \\
& $(5.97-14.72)$ & $(13.28-49.50)$ & $(5.25-12.95)$ & $(1.59-5.94)$ \\
NMP - Pasture and & 15.00 & & & \\
Grassland & $(12.87-28.13)$ & $(37.02-97.82)$ & $(10.22-24.76)$ & $(4.44-11.74)$ \\
\hline
\end{tabular}

Note: values in parenthesis indicate cost range

Figures 6.12 and 6.13 show potential supply curves of TN and TP credits in the single and combine nutrients markets. TN and TP supply curves shift to right in the combine nutrients market. 


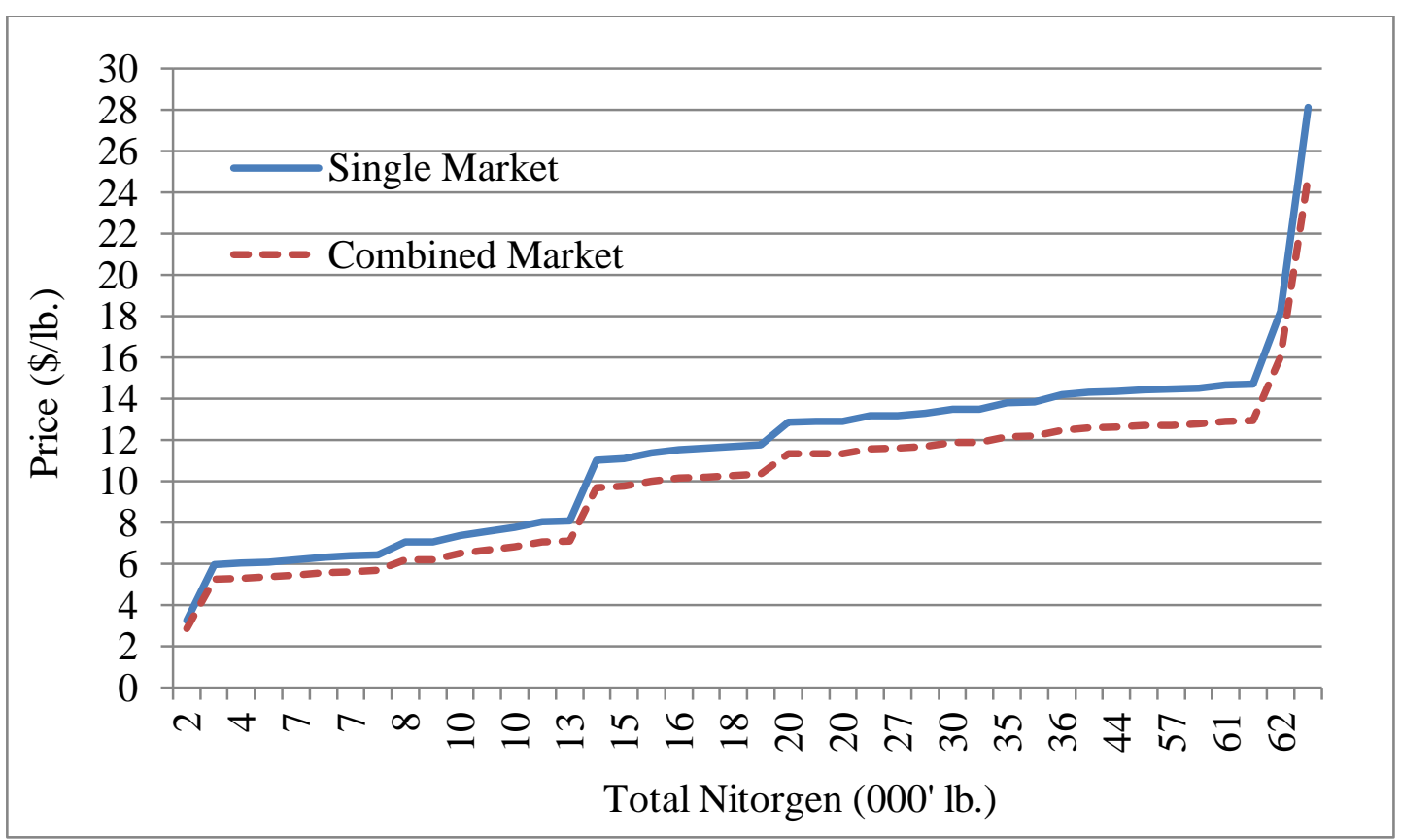

Figure 6.12: Potential Supply of TN Credits from the Implementation of BMPs on the Agricultural Lands

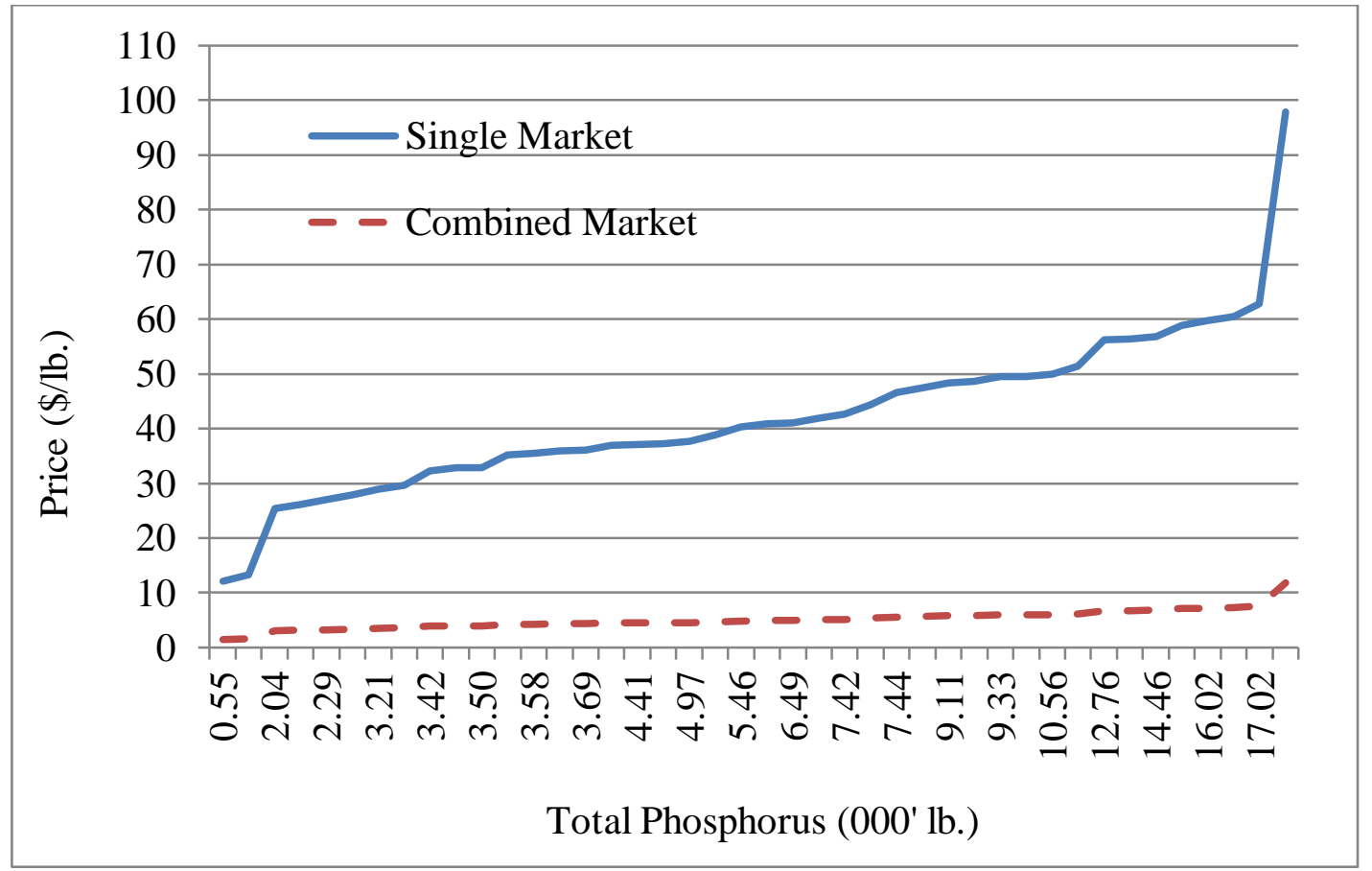

Figure 6.13: Potential Supply of TP Credits from the Implementation of BMPs on agricultural Land 
In the combined nutrient market, the total cost of credit generation is proportionally distributed to the cost of $\mathrm{TN}$ credit generation and the cost of TP credit generation. The proportions were estimated based on the nutrient inflow (i.e. fertilizer dose) to the corn crop in the watershed. The proportion of TP inflow was very low compared to the proportion of TN inflow. This low inflow of TP in the agricultural lands significantly lowers the cost of TP credit generation in the combined nutrient market. This result a much larger shift downward of supply curve for TP compared to TN. The supply curves of TN and TP credits in the single and combine nutrients markets are presented only for the scenario one. This shift of TN and TP supply curves for cover crop and nutrient management plan prevails in all 12 nutrient supply scenarios. The patterns and level of shifts were almost similar in all the scenarios.

Scenario 2: Trading Ratio (1:1), WWTP's Effluent Limit (5.0 mg/l TN, $0.5 \mathrm{mg} / \mathrm{lTP}$ )

The total TP and TN reduction requirements for the WWTPs in the watershed under this scenario were $22,428 \mathrm{lb}$. and $66,395 \mathrm{lb}$. respectively. Table 6.21 summarizes simulation results for this scenario. This scenario required an $85 \%$ increase in cover crop and $76 \%$ increase in nutrient management plan on the crop lands and $15 \%$ increase in nutrient management plan on the pasture/grass lands from the existing level of these BMPs. Farmers do not need to implement rotational grazing on pasture/grasslands to meet WWTP's TN and TP reduction requirements under this scenario too.

Cover crops on the additional 3,150 acres of crop lands generate 11,849 pounds of TN credits and 4,387 pounds of TP credits. Nutrient management plan on the 2,816 acres of crop lands produces 10,596 pounds of TN credits and 2,409 pounds of TP credits. Nutrient management plan on the 35,464 acres of pasture/grassland produces 76,067 pounds of TN credits and 15,697 pounds of TP credits. 
Table 6.21: Potential Nutrient Credit Generation from Agricultural Sources to Meet WWTP Discharge Limits of $5.0 \mathrm{mg} / 1 \mathrm{TN}$ and $0.5 \mathrm{mg} / 1 \mathrm{TP}$ at a 1:1 Trading Ratio

\begin{tabular}{|c|c|c|c|c|c|c|c|c|}
\hline \multirow[t]{2}{*}{ Watershed } & \multicolumn{2}{|c|}{$\begin{array}{c}\text { Cover crop } \\
(85 \%)\end{array}$} & \multicolumn{2}{|c|}{$\begin{array}{c}\text { NMP-Crop land } \\
(76 \%)\end{array}$} & \multicolumn{2}{|c|}{$\begin{array}{c}\text { NMP- Pasture/grassland } \\
(15 \%)\end{array}$} & \multicolumn{2}{|c|}{ Total } \\
\hline & TN & $\mathrm{TP}$ & $\mathrm{TN}$ & $\mathrm{TP}$ & $\mathrm{TN}$ & $\mathrm{TP}$ & $\mathrm{TN}$ & $\mathrm{TP}$ \\
\hline Greenbrier 1 & 2,254 & 1,013 & 2,015 & 546 & 11,378 & 2,480 & 15,647 & 4,039 \\
\hline Second Creek & 2,265 & 902 & 2,025 & 485 & 9,532 & 1,921 & 13,822 & 3,308 \\
\hline Muddy River & 431 & 165 & 386 & 89 & 5,966 & 1,289 & 6,783 & 1,543 \\
\hline Greenbrier 2 & 2,625 & 939 & 2,347 & 506 & 14,372 & 2,956 & 19,344 & 4,401 \\
\hline Howards Creek & 123 & 42 & 110 & 23 & 4,028 & 1,010 & 4,261 & 1,075 \\
\hline Spring Creek & 596 & 197 & 533 & 155 & 10,221 & 2,008 & 11,350 & 2,360 \\
\hline Greenbrier 3 & 2,324 & 735 & 2,078 & 396 & 6,109 & 1,161 & 10,511 & 2,292 \\
\hline Anthony Creek & 67 & 20 & 60 & 10 & 2,650 & 550 & 2,777 & 580 \\
\hline Stony Creek & 37 & 11 & 33 & 6 & 1,431 & 311 & 1,501 & 328 \\
\hline Knapp Creek & 281 & 91 & 252 & 49 & 2,323 & 445 & 2,856 & 585 \\
\hline Sitlington Creek & 287 & 92 & 257 & 49 & 1,658 & 343 & 2,202 & 484 \\
\hline Deer Creek & 199 & 66 & 178 & 35 & 1,808 & 335 & 2,185 & 436 \\
\hline $\begin{array}{l}\text { Greenbrier } 4 \\
\text { Upper }\end{array}$ & 304 & 96 & 272 & 51 & 3,203 & 627 & 3,779 & 774 \\
\hline Greenbrier River & 56 & 18 & 50 & 9 & 1,388 & 261 & 1,494 & 288 \\
\hline Total & 11,849 & 4,387 & 10,596 & 2,409 & 76,067 & 15,697 & 98,512 & 22,493 \\
\hline
\end{tabular}

Greenbrier 1, Second Creek, Greenbrier 2, and Spring Creek supply more than 10,000 pounds of TP and more than 2,000 pounds of TN. Simulation indicates that those 4 subwatersheds generates $62 \%$ of total $\mathrm{TN}$ credit and $63 \%$ of total $\mathrm{TP}$ credit requirements in the watershed. Because linear cost functions were assumed, the average costs of TN and TP reduction from cover crop and nutrient management plan on the crop land and nutrient management plan on the pasture/grasslands would not differ between Scenario 1 and Scenario 2. Scenario 3: Trading Ratio (1:1), WWTP's Effluent Limit (3.0 mg/l TN, $0.1 \mathrm{mg} / \mathrm{l} \mathrm{TP}$ )

The total TP and TN reduction requirements for the WWTPs in the watershed under this scenario were 26,563 pounds and 87,803 pounds respectively. Table 6.22 summarizes simulation results for this scenario. This scenario required an $85 \%$ increase in cover crop and $76 \%$ increase in nutrient management plan on the crop lands and $18 \%$ increase in nutrient management plan on 
the pasture/grass lands from the existing $15 \%$ of cover crop and $24 \%$ of nutrient management plan on the crop lands and 17\% of nutrient management plan on the pasture/hay/grasslands.

Table 6.22: Potential Nutrient Credit Generation from Agricultural Sources to Meet WWTP Discharge Limits of $3 \mathrm{mg} / \mathrm{l} \mathrm{TN}$ and $0.1 \mathrm{mg} / \mathrm{l} \mathrm{TP}$ at a 1:1 Trading Ratio

\begin{tabular}{lcccccccc}
\hline \multirow{2}{*}{ Watershed } & \multicolumn{2}{c}{$\begin{array}{c}\text { Cover crop } \\
(85 \%)\end{array}$} & \multicolumn{2}{c}{$\begin{array}{c}\text { NMP-Crop } \\
\text { land (76\%) }\end{array}$} & $\begin{array}{c}\text { NMP- Pastur/grassland } \\
(18 \%)\end{array}$ & \multicolumn{2}{c}{ Total } \\
\cline { 2 - 9 } & TN & TP & TN & TP & TN & TP & TN & TP \\
\hline Greenbrier 1 & 2,254 & 1,013 & 2,015 & 546 & 8,344 & 2,982 & 12,613 & 4,541 \\
Second Creek & 2,265 & 902 & 2,025 & 485 & 8,261 & 2,305 & 12,551 & 3,692 \\
Muddy River & 431 & 165 & 386 & 89 & 5,170 & 1,546 & 5,987 & 1,800 \\
Greenbrier 2 & 2,625 & 939 & 2,347 & 506 & 20,121 & 4,138 & 25,093 & 5,583 \\
Howards Creek & 123 & 42 & 110 & 23 & 5,639 & 1,414 & 5,872 & 1,479 \\
Spring Creek & 596 & 197 & 533 & 155 & 8,859 & 2,409 & 9,988 & 2,761 \\
Greenbrier 3 & 2,324 & 735 & 2,078 & 396 & 5,294 & 1,393 & 9,696 & 2,524 \\
Anthony Creek & 67 & 20 & 60 & 10 & 3,710 & 770 & 3,837 & 800 \\
Stony Creek & 37 & 11 & 33 & 6 & 1,241 & 373 & 1,311 & 390 \\
Knapp Creek & 281 & 91 & 252 & 49 & 1,901 & 566 & 2,434 & 706 \\
Sitlington Creek & 287 & 92 & 257 & 49 & 1,437 & 412 & 1,981 & 553 \\
Deer Creek & 199 & 66 & 178 & 35 & 1,567 & 402 & 1,944 & 503 \\
Greenbrier 4 & 304 & 96 & 272 & 51 & 2,776 & 752 & 3,352 & 899 \\
Upper Greenbrier & & & & & & & & \\
River & 56 & 18 & 50 & 9 & 1,203 & 314 & 1,309 & 341 \\
\hline Total & 11,849 & 4,387 & 10,596 & 2,409 & 75,523 & 19,776 & 97,968 & 26,572 \\
\hline
\end{tabular}

Cover crops on the 3,150 acres of crop lands generate 11,849 pounds of TN credits and 4,387 pounds of TP credits. Nutrient management plan on the 2,816 acres of crop lands produces 10,596 pounds of TN credits and 2,409 pounds of TP credits. Nutrient management plans on the 42,557 acres of pasture/grassland produces 75,523 pounds of TN credits and 19,776 pounds of TP credits. Greenbrier 2, Greenbrier 1, Second Creek, Spring Creek, and Greenbrier 3 subwatersheds each generated more than 10,000 pounds of TN credits and more than 2,000 pounds of TP credits. 
Scenario 4: Trading Ratio (2:1), WWTP's Effluent Limit ( $8.0 \mathrm{mg} / \mathrm{l} \mathrm{TN}, 1.0 \mathrm{mg} / \mathrm{l} \mathrm{TP}$ )

Under this scenario, agricultural sources supply 34,518 pounds of TP and 77,430 pounds of TN to meet total TP and TP reduction requirements for the WWTPs in the watershed. Table 6.23 summarizes simulation the results for this scenario. This scenario required $85 \%$ increase in area under cover crops and $76 \%$ nutrient management plan on the crop lands and $26 \%$ increase in nutrient management plan on the pasture/grass lands from the existing $15 \%$ of cover crop and $24 \%$ of nutrient management plan on the crop lands and $17 \%$ of nutrient management plan on the pasture/hay/grasslands.

Table 6.23: Potential Nutrient Credit Supply from Agricultural Sources to Meet WWTP Discharge Limits of $8 \mathrm{mg} / \mathrm{l} \mathrm{TN}$ and $1 \mathrm{mg} / \mathrm{l} \mathrm{TP}$ at a 2:1 Trading Ratio

\begin{tabular}{lcccccccc}
\hline \multirow{2}{*}{ Watershed } & \multicolumn{2}{c}{$\begin{array}{c}\text { Cover crop } \\
(85 \%)\end{array}$} & \multicolumn{2}{c}{$\begin{array}{c}\text { NMP- Pasture/grassland } \\
(26 \%)\end{array}$} & \multicolumn{2}{c}{$\begin{array}{c}\text { NMP-Crop land } \\
(76 \%)\end{array}$} & \multicolumn{2}{c}{ Total } \\
\cline { 2 - 9 } & $\mathrm{TN}$ & $\mathrm{TP}$ & $\mathrm{TN}$ & $\mathrm{TP}$ & $\mathrm{TN}$ & $\mathrm{TP}$ & $\mathrm{TN}$ & $\mathrm{TP}$ \\
\hline Greenbrier 1 & 2,254 & 1,013 & 21,239 & 4,299 & 2,015 & 546 & 25,508 & 5,858 \\
Second Creek & 2,265 & 902 & 17,792 & 3,329 & 2,025 & 485 & 22,082 & 4,716 \\
Muddy River & 431 & 165 & 11,137 & 2,234 & 386 & 89 & 11,954 & 2,488 \\
Greenbrier 2 & 2,625 & 939 & 26,828 & 5,518 & 2,347 & 506 & 31,800 & 6,963 \\
Howards Creek & 123 & 42 & 7,518 & 1,751 & 110 & 23 & 7,751 & 1,816 \\
Spring Creek & 596 & 197 & 19,080 & 3,480 & 533 & 155 & 20,209 & 3,832 \\
Greenbrier 3 & 2,324 & 735 & 11,403 & 2,011 & 2,078 & 396 & 15,805 & 3,142 \\
Anthony Creek & 67 & 20 & 4,947 & 953 & 60 & 10 & 5,074 & 983 \\
Stony Creek & 37 & 11 & 2,672 & 538 & 33 & 6 & 2,742 & 555 \\
Knapp Creek & 281 & 91 & 5,068 & 890 & 252 & 49 & 5,601 & 1,030 \\
Sitlington Creek & 287 & 92 & 3,096 & 594 & 257 & 49 & 3,640 & 735 \\
Deer Creek & 199 & 66 & 3,376 & 580 & 178 & 35 & 3,753 & 681 \\
Greenbrier 4 & 304 & 96 & 5,979 & 1,086 & 272 & 51 & 6,555 & 1,233 \\
Upper & & & & & & & & \\
Greenbrier River & 56 & 18 & 2,590 & 471 & 50 & 9 & 2,696 & 498 \\
\hline Total & 11,849 & 4,387 & 142,725 & 27,734 & 10,596 & 2,409 & 165,170 & 34,530 \\
\hline
\end{tabular}

Cover crops on the 3,150 acres of crop lands generate 11,849 pounds of TN credits and 4,387 pounds of TP credits. Nutrient management plans on the 2,816 acres of crop lands produce 10,596 pounds of TN credits and 2,409 pounds of TP credits. Nutrient management plans on the 
61,471 acres of pasture/grassland produce 142,725 pounds of TN credits and 27,734 pounds of TP credits. Greenbrier 2, Greenbrier 1, and Second Creek sub-watersheds each supply more than 20,000 TN credits and more than 4,000 TP credits. Spring Creek, Greenbrier 3, and Muddy River also supply large amounts of both TN and TP credits. The average and range of costs for TN and TP reduction from the cover crop and nutrient management plan on the crop land and nutrient management plan on pasture/grassland were similar to Scenario 3.

Scenario 5: Trading Ratio (2:1), WWTP's Effluent Limit (5.0 mg/l TN, $0.5 \mathrm{mg} / \mathrm{l} \mathrm{TP}$ )

Agricultural sources were required to supply 44,856 pounds of TP and 132,790 pounds of TN to meet total TP and TP reduction requirements the WWTPs in the watershed under this scenario. Table 6.24 summarizes simulation results for this scenario. This scenario required an $85 \%$ increase in cover crop acreage and a $76 \%$ increase in nutrient management plans on the crop lands. In addition, a $36 \%$ increase in nutrient management plans on the pasture/grass lands was required. These increases were based on the existing $15 \%$ of cover crop and $24 \%$ of nutrient management plan on the crop lands and $17 \%$ of nutrient management plan on the pasture/hay/grasslands.

Cover crops on the 3,150 acres of crop lands generate 11,849 pounds of $\mathrm{TN}$ credits and 4,387 pounds of TP credits. Nutrient management plans on 2,816 acres of crop lands produces 10,596 pounds of TN credits and 2,409 pounds of TP credits. Nutrient management plans on 85,114 acres of pasture/grassland produce 190,206 pounds of TN credits and 38,079 pounds of TP credits. Greenbrier 2, Greenbrier 1, and Second Creek supply more than 25,000 TN credits and more than 6,000 TP credits. Spring Creek, Greenbrier 3, and Muddy River also supply high amount of both TN and TP credits. The average costs and range of averages for TN and TP 
reduction from the cover crop and nutrient management plan on the crop land and nutrient management plan on pasture/grassland were similar to Scenarios 3 and 4 .

Table 6.24: Potential Nutrient Credit Supply from Agricultural Sources to Meet WWTP Discharge Limits of $5 \mathrm{mg} / \mathrm{l} \mathrm{TN}$ and $0.5 \mathrm{mg} / \mathrm{l} \mathrm{TP}$ at a 2:1 Trading Ratio

\begin{tabular}{lcccccccc}
\hline \multirow{2}{*}{ Watershed } & \multicolumn{2}{c}{$\begin{array}{c}\text { Cover crop } \\
(85 \%)\end{array}$} & \multicolumn{2}{c}{ NMP- Pasture/grassland } & \multicolumn{2}{c}{$\begin{array}{c}\text { NM-Crop land } \\
(36 \%)\end{array}$} & \multicolumn{2}{c}{ Total } \\
\cline { 2 - 9 } & TN & TP & TN & TP & TN & TP & TN & TP \\
\hline Greenbrier 1 & 2,254 & 1,013 & 25,031 & 5,952 & 2,015 & 546 & 29,300 & 7,511 \\
Second Creek & 2,265 & 902 & 24,147 & 4,738 & 2,025 & 485 & 28,437 & 6,125 \\
Muddy River & 431 & 165 & 15,114 & 3,178 & 386 & 89 & 15,931 & 3,432 \\
Greenbrier 2 & 2,625 & 939 & 36,409 & 7,094 & 2,347 & 506 & 41,381 & 8,539 \\
Howards Creek & 123 & 42 & 10,203 & 2,491 & 110 & 23 & 10,436 & 2,556 \\
Spring Creek & 596 & 197 & 25,894 & 4,952 & 533 & 155 & 27,023 & 5,304 \\
Greenbrier 3 & 2,324 & 735 & 15,475 & 2,862 & 2,078 & 396 & 19,877 & 3,993 \\
Anthony Creek & 67 & 20 & 6,713 & 1,357 & 60 & 10 & 6,840 & 1,387 \\
Stony Creek & 37 & 11 & 3,627 & 745 & 33 & 6 & 3,697 & 762 \\
Knapp Creek & 281 & 91 & 7,180 & 1,334 & 252 & 49 & 7,713 & 1,474 \\
Sitlington Creek & 287 & 92 & 4,202 & 846 & 257 & 49 & 4,746 & 987 \\
Deer Creek & 199 & 66 & 4,582 & 513 & 178 & 35 & 4,959 & 614 \\
Greenbrier 4 & 304 & 96 & 8,114 & 1,546 & 272 & 51 & 8,690 & 1,693 \\
Upper Greenbrier & & & & & & & & \\
River & 56 & 18 & 3,515 & 471 & 50 & 9 & 3,621 & 498 \\
\hline Total & 11,849 & 4,387 & 190,206 & 38,079 & 10,596 & 2,409 & 212,651 & 44,875 \\
\hline
\end{tabular}

Scenario 6: Trading Ratio (2:1), WWTP's Effluent Limit (3.0 mg/l TN, $0.1 \mathrm{mg} / \mathrm{l} \mathrm{TP}$ )

Under this scenario, agricultural sources need to supply 53,126 pounds of TP and 175,606 pounds of TN to meet total TP and TP demands from the WWTPs. Table 6.25 summarizes simulation results for this scenario. This scenario required $85 \%$ cover crop BMPs and $76 \%$ nutrient management plans on the crop lands along with $43 \%$ of pasture/grass lands in nutrient management plans. These are far above the existing levels of these BMPs on crop and pasture/hay/grasslands.

Cover crops on the 3,150 acres of crop lands generate 11,849 pounds of $\mathrm{TN}$ credits and 4,387 pounds of TP credits. Nutrient management plans on the 2,816 acres of crop lands produce 
10,596 pounds of TN credits and 2,409 pounds of TP credits. Nutrient management plans on the 103,938 acres of pasture/grassland produce 228,925 pounds of TN credits and 46,370 pounds of TP credits. Greenbrier 2, Greenbrier 1, Second Creek, and Spring Creek each supply more than 30,000 TN credits and more than 6,000 TP credits. Greenbrier 3, Muddy River, and Howards Creek also supply large amounts of both TN and TP credits. The average costs for TN and TP reductions from the cover crop and nutrient management plan BMPs on the crop land and nutrient management plan BMPs on pasture/grassland were similar to Scenarios 3, 4, and 5.

Table 6.25: Potential Nutrient Credit Supply from Agricultural Sources to Meet WWTP Discharge Limits of $3 \mathrm{mg} / 1 \mathrm{TN}$ and $0.1 \mathrm{mg} / 1 \mathrm{TP}$ at a 2:1 Trading Ratio

\begin{tabular}{lcccccccc}
\hline \multirow{2}{*}{ Watershed } & \multicolumn{2}{c}{$\begin{array}{c}\text { Cover crop } \\
(85 \%)\end{array}$} & \multicolumn{2}{c}{ NMP- Pasture/grassland } & \multicolumn{2}{c}{$\begin{array}{c}\text { NMP-Crop land } \\
(76 \%)\end{array}$} & & \multicolumn{2}{c}{ Total } \\
\cline { 2 - 9 } & TN & TP & TN & TP & TN & TP & TN & TP \\
\hline Greenbrier 1 & 2,254 & 1,013 & 32,616 & 7,109 & 2,015 & 546 & 36,885 & 8,668 \\
Second Creek & 2,265 & 902 & 29,866 & 5,506 & 2,025 & 485 & 34,156 & 6,893 \\
Muddy River & 431 & 165 & 18,694 & 3,694 & 386 & 89 & 19,511 & 3,948 \\
Greenbrier 2 & 2,625 & 939 & 41,200 & 8,474 & 2,347 & 506 & 46,172 & 9,919 \\
Howards Creek & 123 & 42 & 12,620 & 3,164 & 110 & 23 & 12,853 & 3,229 \\
Spring Creek & 596 & 197 & 29,301 & 5,755 & 533 & 155 & 30,430 & 6,107 \\
Greenbrier 3 & 2,324 & 735 & 17,512 & 3,326 & 2,078 & 396 & 21,914 & 4,457 \\
Anthony Creek & 67 & 20 & 8,303 & 1,723 & 60 & 10 & 8,430 & 1,753 \\
Stony Creek & 37 & 11 & 4,486 & 972 & 33 & 6 & 4,556 & 989 \\
Knapp Creek & 281 & 91 & 9,080 & 1,739 & 252 & 49 & 9,613 & 1,879 \\
Sitlington Creek & 287 & 92 & 5,197 & 1,074 & 257 & 49 & 5,741 & 1,215 \\
Deer Creek & 199 & 66 & 5,667 & 1,050 & 178 & 35 & 6,044 & 1,151 \\
Greenbrier 4 & 304 & 96 & 10,035 & 1,964 & 272 & 51 & 10,611 & 2,111 \\
Upper & & & & & & & & \\
Greenbrier River & 56 & 18 & 4,348 & 820 & 50 & 9 & 4,454 & 847 \\
\hline Total & 11,849 & 4,387 & 228,925 & 46,370 & 10,596 & 2,409 & 251,370 & 53,166 \\
\hline
\end{tabular}

Nutrient credit supply Scenarios 1 to 3 represent 1:1 trading ratio while Scenarios 4 to 6 represent 2:1 trading ratio with different level of $\mathrm{TN}$ and $\mathrm{TP}$ effluent limits. The existing levels of BMPs were assumed to be a baseline for all agricultural sources. All three scenarios were 
feasible for TN and TP credits trading between agricultural sources and WWTPs both in single nutrient market and combine nutrients market.

\subsubsection{BASELINE: 100\% NUTRIENT MANAGEMENT PLAN}

This section presents the simulation results considering $100 \%$ nutrient management plan as a baseline for the agricultural sources. Each farmer must maintain this minimum standard baseline on crop and pasture/grassland land in order to generate marketable TN and TP credits from the agricultural sources. The nutrient reduction from the nutrient management plan was not considered in the simulation process. However, the costs for maintaining $100 \%$ nutrient management plan in each sub-watershed was estimated and included in the per unit TN and TP costs estimations. TN and TP credits supply for individual trading scenario is discussed below.

Scenario 7: Trading Ratio (1:1), WWTP's Effluent Limit (8.0 mg/l TN, $1 \mathrm{mg} / \mathrm{l} \mathrm{TP})$

The total TP and TN reduction requirements for the WWTPs under this scenario were 17,259 lb. and 38,715 lb., respectively. Cover crops on the crop lands were simulated first to estimate the low cost TP and TN credits. Table 6.26 summarizes the simulation results and presents amounts of TN and TP supplies from each sub-watershed. Cover crop BMPs on 100\% of crop land and prescribed grazing on $27 \%$ of pasture/grasslands can meet TP and TN demands under this scenario. Cover crops on 3,706 acres of crop land generate 13,934 pounds of TN credits and 5,151 pounds of TP credits. Prescribed grazing on the 63,836 acres of pasture/grassland produces 89,754 pounds of TN credits and 12,205 pounds of TP credits. Four sub-watersheds: Greenbrier 1, Second Creek, Greenbrier 2, Spring Creek each supply more than 10,000 pounds of TN credits and 1,500 pounds of TP credits. 
Table 6.26: Potential Nutrient Credit Supply from Agricultural Sources to Meet WWTP Discharge Limits of $8 \mathrm{mg} / 1 \mathrm{TN}$ and $1 \mathrm{mg} / 1 \mathrm{TP}$ at a $1: 1$ Trading Ratio

\begin{tabular}{lcccccc}
\hline \multirow{2}{*}{ Sub-Watershed } & \multicolumn{2}{c}{ Cover Crop (100\%) } & \multicolumn{2}{c}{ Prescribed Grazing (17\%) } & \multicolumn{2}{c}{ Total Credits } \\
\cline { 2 - 7 } & TN (lb.) & TP (lb.) & TN (lb.) & TP (lb.) & TN (lb.) & TP (lb.) \\
\hline Greenbrier 1 & 2,651 & 1,191 & 14,907 & 2,141 & 17,558 & 3,332 \\
Second Creek & 2,663 & 1,059 & 11,175 & 1,484 & 13,838 & 2,543 \\
Muddy River & 507 & 193 & 6,993 & 995 & 7,500 & 1,188 \\
Greenbrier 2 & 3,087 & 1,104 & 14,867 & 2,016 & 17,954 & 3,120 \\
Howards Creek & 145 & 49 & 4,722 & 779 & 4,867 & 828 \\
Spring Creek & 701 & 231 & 11,983 & 1,551 & 12,684 & 1,782 \\
Greenbrier 3 & 2,733 & 864 & 7,162 & 896 & 9,895 & 1,760 \\
Anthony Creek & 79 & 23 & 3,107 & 425 & 3,186 & 448 \\
Stony Creek & 44 & 14 & 1,679 & 239 & 1,723 & 253 \\
Knapp Creek & 331 & 107 & 3,714 & 469 & 4,045 & 576 \\
Sitlington Creek & 337 & 107 & 1,944 & 264 & 2,281 & 371 \\
Deer Creek & 233 & 77 & 2,120 & 260 & 2,353 & 337 \\
Greenbrier 4 & 358 & 112 & 3,755 & 484 & 4,113 & 596 \\
Upper Greenbrier & 65 & 20 & 1,626 & 202 & 1,691 & 222 \\
\hline Total & 13,934 & 5,151 & 89,754 & 12,205 & 103,688 & 17,356 \\
\hline
\end{tabular}

Table 6.27 summarizes average costs of TN and TP reduction from the cover crop BMPs on the crop lands and prescribed grazing BMPs on the pasture/grass lands. The average per unit cost of $\mathrm{TN}$ reduction from the prescribed grazing on the pasture/grasslands was $\$ 73.64$ and $\$ 64.81$ in the single market and combined nutrient market, respectively. The average per unit cost of TN reduction from the prescribed grazing on the pasture/grasslands was $\$ 550$ and $\$ 55.90$ in the single market and combined nutrient market, respectively.

Table 6.27: Average per Unit Cost of Nutrient Reduction for BMPs on Crop and Pasture/Grass Lands

\begin{tabular}{lcccc}
\hline & \multicolumn{2}{c}{ Single market } & \multicolumn{2}{c}{ Combine market } \\
\cline { 2 - 5 } BMP & $\mathrm{TN}(\$ / \mathrm{lb})$. & $\mathrm{TP}(\$ / \mathrm{lb})$. & $\mathrm{TN}(\$ / \mathrm{lb})$. & $\mathrm{TP}(\$ / \mathrm{lb})$. \\
\hline Cover Crop & 17.08 & 51.44 & 15.02 & 6.17 \\
& $(8.38-20.48)$ & $(18.56-67.89)$ & $(7.33-17.88)$ & $(2.22-8.14)$ \\
Prescribed & 73.64 & 550 & 64.81 & 55.90 \\
Grazing & $(62.22-87.81)$ & $(377-647)$ & $(54.76-77.27)$ & $(38.34-65.82)$ \\
\hline
\end{tabular}

Note: values in parenthesis indicate cost range 
Scenario 8: Trading Ratio (1:1), WWTP's Effluent Limit (5.0 mg/l TN, $0.5 \mathrm{mg} / \mathrm{l} \mathrm{TP}$ )

The total TP and TN reduction requirements for the WWTPs in the watershed under this scenario were $22,428 \mathrm{lb}$. and $66,395 \mathrm{lb}$. respectively. Table 6.28 summarizes simulation results for this scenario. Cover crops BMPs on 100\% crop land and prescribed grazing BMPs on $34 \%$ of pasture/grasslands can meet TP and TN reduction requirements for the WWTPs under this scenario. Cover crops on 3,706 acres of crop lands generate 13,934 pounds of TN credits and 5,151 pounds of TP credits. Prescribed grazing on the 80,386 acres of pasture/grassland produces 127,297 pounds of TN credits and 17,293 pounds of TP credits. Four sub-watersheds: Greenbrier 1, Second Creek, Greenbrier 2, Spring Creek each supply more than 15,000 pounds of TN credits and 2,000 pounds of TP credits.

Table 6.28: Potential Nutrient Credit Supply from Agricultural Sources to Meet WWTP Discharge Limits of $5 \mathrm{mg} / \mathrm{l} \mathrm{TN}$ and $0.5 \mathrm{mg} / \mathrm{l} \mathrm{TP}$ at a $1: 1$ Trading Ratio

\begin{tabular}{lcccccc}
\hline \multirow{2}{*}{ Sub-Watershed } & \multicolumn{2}{c}{ Cover Crop (100\%) } & \multicolumn{2}{c}{ Prescribed Grazing (24\%) } & \multicolumn{2}{c}{ Total Credits } \\
\cline { 2 - 7 } & TN (lb.) & TP (lb.) & TN (lb.) & TP (lb.) & TN (lb.) & TP (lb.) \\
\hline Greenbrier 1 & 2,651 & 1,191 & 18,831 & 2,705 & 21,482 & 3,896 \\
Second Creek & 2,663 & 1,059 & 15,776 & 2,095 & 18,439 & 3,154 \\
Muddy River & 507 & 193 & 9,873 & 1,405 & 10,380 & 1,598 \\
Greenbrier 2 & 3,087 & 1,104 & 23,788 & 3,225 & 26,875 & 4,329 \\
Howards Creek & 145 & 49 & 6,667 & 1,101 & 6,812 & 1,150 \\
Spring Creek & 701 & 231 & 16,917 & 2,190 & 17,618 & 2,421 \\
Greenbrier 3 & 2,733 & 864 & 10,111 & 1,265 & 12,844 & 2,129 \\
Anthony Creek & 79 & 23 & 4,386 & 600 & 4,465 & 623 \\
Stony Creek & 44 & 14 & 2,370 & 338 & 2,414 & 352 \\
Knapp Creek & 331 & 107 & 5,243 & 662 & 5,574 & 769 \\
Sitlington Creek & 337 & 107 & 2,744 & 373 & 3,081 & 480 \\
Deer Creek & 233 & 77 & 2,994 & 366 & 3,227 & 443 \\
Greenbrier 4 & 358 & 112 & 5,301 & 683 & 5,659 & 795 \\
Upper Greenbrier & 65 & 20 & 2,296 & 285 & 2,361 & 305 \\
River & & & & & & 141,231 \\
\hline Total & 13,934 & 5,151 & 127,297 & 17,293 & 22,444 \\
\hline
\end{tabular}

Table 6.29 summarizes average costs per $\mathrm{lb}$. of $\mathrm{TN}$ and $\mathrm{TP}$ reduction from cover crop BMPs on the crop lands and prescribed grazing BMPs on the pasture/grass lands. The average 
costs for TN and TP reduction from the prescribed grazing on pasture/grassland were lower than Scenario 7. More pasture/grassland under the prescribed grazing increases the amount of nutrient reduction from the pasture/grassland. However, the cost for 100\% NMP for all farmers remains the same. This increase in the amount of nutrient credits supply reduces the average cost of nutrient reduction from the prescribed grazing on the pasture/grasslands. The average per unit cost of $\mathrm{TN}$ reduction from the prescribed grazing on the pasture/grasslands was $\$ 55.23$ and $\$ 48.60$ in the single market and combined nutrient market, respectively. Similarly, the average per unit cost of TN reduction from the prescribed grazing on the pasture/grasslands was $\$ 412$ and \$59.54 in the single market and combined nutrient market, respectively.

Table 6.29: Average per Unit Cost of Nutrient Reduction from BMPs on Crop and Pasture/Grass Lands

\begin{tabular}{lcccc}
\hline & \multicolumn{2}{c}{ Single market } & \multicolumn{2}{c}{ Combine market } \\
\cline { 2 - 5 } BMP & $\mathrm{TN}(\$ / \mathrm{lb})$. & $\mathrm{TP}(\$ / \mathrm{lb})$. & $\mathrm{TN}(\$ / \mathrm{lb})$. & $\mathrm{TP}(\$ / \mathrm{lb})$. \\
\hline Cover Crop & 17.08 & 51.44 & 15.02 & 6.17 \\
& $(8.38-20.48)$ & $(18.56-67.89)$ & $(7.33-17.88)$ & $(2.22-8.14)$ \\
Prescribed & 55.23 & 412 & 48.60 & 59.54 \\
Grazing & $(46.85-58.59)$ & $(283-479)$ & $(41.22-51.56)$ & $(34.04-54.75)$ \\
\hline
\end{tabular}

Note: values in parenthesis indicate cost range

Scenario 9: Trading Ratio (1:1), WWTP's Effluent Limit (3.0 mg/l TN, $0.1 \mathrm{mg} / \mathrm{l} \mathrm{TP})$

$\mathrm{TP}$ and $\mathrm{TN}$ reduction requirements for the seven WWTPs under this scenario were 26,563 pounds and 87,803 pounds, respectively. Table 6.30 summarizes simulation results for this scenario. Cover crop BMPs on $100 \%$ of crop lands and prescribed grazing BMPs on $40 \%$ of pasture/grasslands can meet these $\mathrm{TP}$ and $\mathrm{TN}$ reduction requirements. Cover crops BMPs on 3,706 acres of crop lands potentially generate 13,934 pounds of $\mathrm{TN}$ credits and 5,151 pounds of TP credits. Prescribed grazing on the 94,572 acres of pasture/grassland produces 159,123 pounds of TN credits and 21,617 pounds of TP credits. Four sub-watersheds: Greenbrier 1, Second 
Creek, Greenbrier 2, Spring Creek each supply more than 20,000 pounds of TN credits and 2,500 pounds of TP credits.

Table 6.30: Potential Nutrient Credit Supply from Agricultural Sources to Meet WWTP Discharge Limits of $3 \mathrm{mg} / \mathrm{l} \mathrm{TN}$ and $0.1 \mathrm{mg} / \mathrm{l} \mathrm{TP}$ at a $1: 1$ Trading Ratio

\begin{tabular}{lcccccc}
\hline Sub-Watershed & \multicolumn{2}{c}{ Cover Crop (100\%) } & \multicolumn{2}{c}{ Prescribed Grazing (40\%) } & \multicolumn{2}{c}{ Total Credits } \\
\hline & TN $(\mathrm{lb})$. & TP $(\mathrm{lb})$. & TN $(\mathrm{lb})$. & TP $(\mathrm{lb})$. & TN $(\mathrm{lb})$. & TP $(\mathrm{lb})$. \\
\hline Greenbrier 1 & 2,651 & 1,191 & 23,539 & 3,381 & 26,190 & 4,572 \\
Second Creek & 2,663 & 1,059 & 19,720 & 2,619 & 22,383 & 3,678 \\
Muddy River & 507 & 193 & 12,342 & 1,756 & 12,849 & 1,949 \\
Greenbrier 2 & 3,087 & 1,104 & 29,735 & 4,031 & 32,822 & 5,135 \\
Howards Creek & 145 & 49 & 8,333 & 1,376 & 8,478 & 1,425 \\
Spring Creek & 701 & 231 & 21,146 & 2,737 & 21,847 & 2,968 \\
Greenbrier 3 & 2,733 & 864 & 12,639 & 1,582 & 15,372 & 2,446 \\
Anthony Creek & 79 & 23 & 5,483 & 750 & 5,562 & 773 \\
Stony Creek & 44 & 14 & 2,962 & 423 & 3,006 & 437 \\
Knapp Creek & 331 & 107 & 6,554 & 827 & 6,885 & 934 \\
Sitlington Creek & 337 & 107 & 3,431 & 466 & 3,768 & 573 \\
Deer Creek & 233 & 77 & 3,742 & 458 & 3,975 & 535 \\
Greenbrier 4 & 358 & 112 & 6,627 & 854 & 6,985 & 966 \\
Upper Greenbrier & 65 & 20 & 2,870 & 357 & 2,935 & 377 \\
River & 13,934 & 5,151 & 159,123 & 21,617 & 173,057 & 26,768 \\
\hline Total & \multicolumn{7}{c}{}
\end{tabular}

Table 6.31 summarizes average per unit costs of $\mathrm{TN}$ and TP reduction from cover crop BMPs on the crop lands and prescribed grazing BMPs on the pasture/grass lands. The average per $1 \mathrm{~b}$. costs for TN and TP reductions from the prescribed grazing on pasture/grassland were lower than the Scenarios 7 and 8. More pasture/grassland under prescribed grazing BMPs increases the amount of nutrient reduction from the pasture/grassland and reduces the average cost of nutrient reduction from the prescribed grazing on the pasture/grasslands. The average per unit cost of TN reduction from the prescribed grazing on the pasture/grasslands was $\$ 46.43$ and $\$ 40.86$ in the single market and combined nutrient market, respectively. Similarly, the average 
per unit cost of TN reduction from the prescribed grazing on the pasture/grasslands was $\$ 346$ and $\$ 41.63$ in the single market and combined nutrient market, respectively.

Table 6.31: Average per Unit Cost of Nutrient Reduction from BMPs on Crop and Pasture/Grass Lands

\begin{tabular}{lcccc}
\hline BMP & \multicolumn{2}{c}{ Single market } & \multicolumn{2}{c}{ Combined market } \\
\cline { 2 - 5 } & $\mathrm{TN}(\$ / \mathrm{lb})$. & $\mathrm{TP}(\$ / \mathrm{lb})$. & $\mathrm{TN}(\$ / \mathrm{lb})$. & $\mathrm{TP}(\$ / \mathrm{lb})$. \\
\hline Cover Crop & 17.08 & 51.44 & 15.02 & 6.17 \\
& $(8.38-20.48)$ & $(18.56-67.89)$ & $(7.33-17.88)$ & $(2.22-8.14)$ \\
Prescribed & 46.43 & 346 & 40.86 & 41.63 \\
Grazing & $(39.38-49.26)$ & $(238-402)$ & $(34.66-43.34)$ & $(28.29-48.29)$ \\
\hline
\end{tabular}

Note: values in parenthesis indicate cost range

Scenario 10: Trading Ratio (2:1), WWTP's Effluent Limit ( $8.0 \mathrm{mg} / \mathrm{l} \mathrm{TN}, 1 \mathrm{mg} / \mathrm{l} \mathrm{TP}$ )

Agricultural sources would be required to supply 34,518 pounds of TP and 77,430 pounds of TN to meet TP and TP reduction requirements for the WWTPs under this scenario.

Table 6.32 summarizes simulation results for this scenario.

Table 6.32: Potential Nutrient Credit Supply from Agricultural Sources to Meet WWTP Discharge Limits of $8 \mathrm{mg} / 1 \mathrm{TN}$ and $1 \mathrm{mg} / 1 \mathrm{TP}$ at a 2:1 Trading Ratio

\begin{tabular}{lcccccc}
\hline Sub-Watershed & \multicolumn{2}{c}{ Cover Crop (100\%) } & \multicolumn{2}{c}{ Prescribed Grazing (50\%) } & \multicolumn{2}{c}{ Total Credits } \\
\cline { 2 - 7 } & TN (lb.) & TP (lb.) & TN (lb.) & TP (lb.) & TN (lb.) & TP (lb.) \\
\hline Greenbrier 1 & 2,651 & 1,191 & 34,524 & 4,959 & 37,175 & 6,150 \\
Second Creek & 2,663 & 1,059 & 26,294 & 3,492 & 28,957 & 4,551 \\
Muddy River & 507 & 193 & 16,456 & 2,342 & 16,963 & 2,535 \\
Greenbrier 2 & 3,087 & 1,104 & 39,647 & 5,375 & 42,734 & 6,479 \\
Howards Creek & 145 & 49 & 11,111 & 1,835 & 11,256 & 1,884 \\
Spring Creek & 701 & 231 & 28,196 & 3,650 & 28,897 & 3,881 \\
Greenbrier 3 & 2,733 & 864 & 16,851 & 2,109 & 19,584 & 2,973 \\
Anthony Creek & 79 & 23 & 8,041 & 1,100 & 8,120 & 1,123 \\
Stony Creek & 44 & 14 & 3,950 & 564 & 3,994 & 578 \\
Knapp Creek & 331 & 107 & 8,738 & 1,103 & 9,069 & 1,210 \\
Sitlington Creek & 337 & 107 & 4,575 & 622 & 4,912 & 729 \\
Deer Creek & 233 & 77 & 4,989 & 610 & 5,222 & 687 \\
Greenbrier 4 & 358 & 112 & 8,835 & 1,139 & 9,193 & 1,251 \\
Upper Greenbrier & 65 & 20 & 3,827 & 476 & 3,892 & 496 \\
River & & & & & & \\
Total & 13,934 & 5,151 & 216,034 & 29,376 & 229,968 & 34,527 \\
\hline
\end{tabular}


Cover crop BMPs on a $100 \%$ of crop lands and prescribed grazing BMPs on $50 \%$ of pasture/grasslands can meet $\mathrm{TP}$ and $\mathrm{TN}$ reduction requirements for the WWTPs under this scenario. Cover crop BMPs on the 3,706 acres of crop lands generate 13,934 pounds of TN credits and 5,151 pounds of TP credits. Prescribed grazing BMPs on 118,215 acres of pasture/grassland produce 216,034 pounds of $\mathrm{TN}$ credits and 29,376 pounds of TP credits. Greenbrier 1, Second Creek, Greenbrier 2, Spring Creek sub-watersheds generate the highest levels of TN and TP credits.

Table 6.33 summarizes the average per unit costs of TN and TP reduction from the cover crop on the crop lands and prescribed grazing on the pasture/grass lands. The average costs per lb. for TN and TP reductions from prescribed grazing BMPs on pasture/grassland were lower than Scenario 7, 8, and 9. The average per $1 \mathrm{~b}$. cost of TN reduction from prescribed grazing BMPs on the pasture/grasslands was $\$ 37.30$ and $\$ 32.82$ in the single and combined nutrient market, respectively. Similarly, the average per $\mathrm{lb}$. cost of TN reduction from prescribed grazing BMPs on the pasture/grasslands was $\$ 278$ and $\$ 33.46$ in the single market and combined nutrient market, respectively.

Table 6.33: Average per Unit Cost of Nutrient Reduction from BMPs on Crop and Pasture/Grass Lands

\begin{tabular}{lcccc}
\hline BMP & \multicolumn{2}{c}{ Single market } & \multicolumn{2}{c}{ Combined market } \\
\cline { 2 - 5 } & $\mathrm{TN}(\$ / \mathrm{lb})$. & $\mathrm{TP}(\$ / \mathrm{lb})$. & $\mathrm{TN}(\$ / \mathrm{lb})$. & $\mathrm{TP}(\$ / \mathrm{lb})$. \\
\hline Cover Crop & 17.08 & 51.44 & 15.02 & 6.17 \\
& $(8.38-20.48)$ & $(18.56-67.89)$ & $(7.33-17.88)$ & $(2.22-8.14)$ \\
Grassland & 37.30 & 278 & 32.82 & 33.46 \\
Management & $(31.92-39.74)$ & $(193-326)$ & $(28.09-35.13)$ & $(23.19-39.18)$ \\
\hline
\end{tabular}

Note: values in parenthesis indicate cost range

Scenario 11: Trading Ratio (2:1), WWTP's Effluent Limit (5.0 mg/l TN, $0.5 \mathrm{mg} / \mathrm{l} \mathrm{TP}$ )

Agricultural sources would be required to supply 44,856 pounds of TP and 132,790 pounds of TN to meet TP and TP reduction requirements of WWTPs under this scenario. Table 
6.34 summarizes simulation results for this scenario. Cover crops BMPs on 100\% of crop land and prescribed grazing BMPs on 65\% pasture/grasslands can meet these TP and TN reduction requirements. Cover crop BMPs on the 3,706 acres of crop lands generate 13,934 pounds of TN credits and 5,151 pounds of TP credits. Prescribed grazing BMPs on the 153,679 acres of pasture/grassland produce 290,176 pounds of TN credits and 39,709 pounds of TP credits. Greenbrier 1, Second Creek, Greenbrier 2, and Spring Creek sub-watersheds each supply more than 35,000 pounds of TN credits and 5,000 pounds of TP credits.

Table 6.34: Potential Nutrient Credit Supply from Agricultural Sources to Meet WWTP Discharge Limits of $5 \mathrm{mg} / 1 \mathrm{TN}$ and $0.5 \mathrm{mg} / 1 \mathrm{TP}$ at a 2:1 Trading Ratio

\begin{tabular}{lcccccc}
\hline \multirow{2}{*}{ Sub-Watershed } & \multicolumn{2}{c}{ Cover Crop (100\%) } & \multicolumn{2}{c}{ Grassland Management (65\%) } & \multicolumn{2}{c}{ Total Credits } \\
\cline { 2 - 7 } & TN (lb.) & TP (lb.) & TN (lb.) & TP (lb.) & TN & TP (lb.) \\
\hline Greenbrier 1 & 2,651 & 1,191 & 43,155 & 6,199 & 45,806 & 7,390 \\
Second Creek & 2,663 & 1,059 & 36,154 & 4,802 & 38,817 & 5,861 \\
Muddy River & 507 & 193 & 22,628 & 3,220 & 23,135 & 3,413 \\
Greenbrier 2 & 3,087 & 1,104 & 54,515 & 7,390 & 57,602 & 8,494 \\
Howards Creek & 145 & 49 & 15,277 & 2,523 & 15,422 & 2,572 \\
Spring Creek & 701 & 231 & 38,769 & 5,019 & 39,470 & 5,250 \\
Greenbrier 3 & 2,733 & 864 & 23,171 & 2,900 & 25,904 & 3,764 \\
Anthony Creek & 79 & 23 & 10,599 & 1,450 & 10,678 & 1,473 \\
Stony Creek & 44 & 14 & 5,331 & 775 & 5,375 & 789 \\
Knapp Creek & 331 & 107 & 12,015 & 1,516 & 12,346 & 1,623 \\
Sitlington Creek & 337 & 107 & 6,290 & 856 & 6,627 & 963 \\
Deer Creek & 233 & 77 & 6,860 & 838 & 7,093 & 915 \\
Greenbrier 4 & 358 & 112 & 12,149 & 1,567 & 12,507 & 1,679 \\
Upper Greenbrier & 65 & 20 & 5,263 & 654 & 5,328 & 674 \\
River & 13,934 & 5,151 & 292,176 & 39,709 & 306,110 & 44,860 \\
\hline Total & & & &
\end{tabular}

Table 6.35 summarizes the average per unit costs of TN and TP reduction from cover crop BMPs on crop lands and prescribed grazing BMPs on pasture/grass lands. The average per lb. costs for TN and TP reductions from prescribed grazing were lower than in Scenarios 7, 8, 9 and 10. The average per $\mathrm{lb}$. costs of $\mathrm{TN}$ reduction from prescribed grazing was $\$ 30.40$ and 
\$26.75 in the single market and combined nutrient market, respectively. Similarly, the average per lb. cost of TN reduction from the prescribed grazing on the pasture/grasslands was $\$ 226$ and \$27.23 in the single market and combined nutrient market, respectively.

Table 6.35: Average per Unit Cost of Nutrient Reduction from BMPs on Crop and Pasture/Grass Lands

\begin{tabular}{lcccc}
\hline & \multicolumn{2}{c}{ Single market } & \multicolumn{2}{c}{ Combined market } \\
\cline { 2 - 5 } Lands.BMP & $\mathrm{TN}(\$ / \mathrm{lb})$. & $\mathrm{TP}(\$ / \mathrm{lb})$. & $\mathrm{TN}(\$ / \mathrm{lb})$. & $\mathrm{TP}(\$ / \mathrm{lb})$. \\
\hline Cover Crop & 17.08 & 51.44 & 15.02 & 6.17 \\
& $(8.38-20.48)$ & $(18.56-67.89)$ & $(7.33-17.88)$ & $(2.22-8.14)$ \\
Grassland & 30.40 & 226 & 26.75 & 27.23 \\
Management & $(25.81-32.14)$ & $(156-264)$ & $(22.71-28.41)$ & $(18.75-31.71)$ \\
\hline
\end{tabular}

Note: values in parenthesis indicate cost range

Scenario 12: Trading Ratio (2:1), WWTP's Effluent Limit (3.0 mg/l TN, $0.1 \mathrm{mg} / \mathrm{lTP}$ )

Under this last scenario, agricultural sources would be required to supply 53,126 pounds of TP and 175,606 pounds of TN to meet TP and TP credit demands from the WWTPs. Table 6.36 summarizes simulation results for this scenario. Cover crops BMPs on 100\% of crop land and prescribed grazing BMPs on $75 \%$ of pasture/grasslands could meet TP and TN reduction requirements under this scenario. Cover crops BMPs on 3,706 acres of crop land generate 13,934 pounds of TN credits and 5,151 pounds of TP credits. Prescribed grazing BMPs on 177,322 acres of pasture/grassland produce 290,176 pounds of TN credits and 39,709 pounds of TP credits. Four sub-watersheds: Greenbrier 1, Second Creek, Greenbrier 2, Spring Creek each supply more than 45,000 pounds of TN credits and 6,000 pounds of TP credits. 
Table 6.36: Potential Nutrient Credit Supply from Agricultural Sources to Meet WWTP Discharge Limits of 3mg/l TN and 0.1mg/l TP at a 2:1 Trading Ratio

\begin{tabular}{lcccccc}
\hline Sub-Watershed & \multicolumn{2}{c}{ Cover Crop (100\%) } & \multicolumn{2}{c}{ Prescribed Grazing (75\%) } & \multicolumn{2}{c}{ Total Credits } \\
\cline { 2 - 6 } & TN (lb.) & TP (lb.) & TN (lb.) & TP (lb.) & TN (lb.) & TP (lb.) \\
\hline Greenbrier 1 & 2,651 & 1,191 & 53,356 & 7,665 & 56,007 & 8,856 \\
Second Creek & 2,663 & 1,059 & 44,700 & 5,937 & 47,363 & 6,996 \\
Muddy River & 507 & 193 & 27,977 & 3,982 & 28,484 & 4,175 \\
Greenbrier 2 & 3,087 & 1,104 & 67,400 & 9,137 & 70,487 & 10,241 \\
Howards Creek & 145 & 49 & 18,055 & 2,982 & 18,200 & 3,031 \\
Spring Creek & 701 & 231 & 45,818 & 5,931 & 46,519 & 6,162 \\
Greenbrier 3 & 2,733 & 864 & 27,384 & 3,427 & 30,117 & 4,291 \\
Anthony Creek & 79 & 23 & 11,878 & 1,625 & 11,957 & 1,648 \\
Stony Creek & 44 & 14 & 6,418 & 916 & 6,462 & 930 \\
Knapp Creek & 331 & 107 & 14,200 & 1,792 & 14,531 & 1,899 \\
Sitlington Creek & 337 & 107 & 7,434 & 1,012 & 7,771 & 1,119 \\
Deer Creek & 233 & 77 & 8,108 & 991 & 8,341 & 1,068 \\
Greenbrier 4 & 358 & 112 & 14,357 & 1,852 & 14,715 & 1,964 \\
Upper Greenbrier & 65 & 20 & 6,220 & 774 & 6,285 & 794 \\
River & & & & & & 367,023 \\
\hline Total & 13,934 & 5,151 & 353,305 & 489 & 53,174 \\
\hline
\end{tabular}

Table 6.37 summarizes average per unit costs of $\mathrm{TN}$ and $\mathrm{TP}$ reduction from cover crop BMPs on crop lands and prescribed grazing BMPs on pasture/grass lands. The average per lb. costs for TN and TP reduction from the prescribed grazing were lower than in Scenarios 7, 8, 9 10 , and 11 . The average per unit cost of TN reduction from prescribed grazing was $\$ 27.26$ and $\$ 23.99$ in the single market and combined nutrient market, respectively. Similarly, the average per unit cost of TN reduction from prescribed grazing was \$203 and \$14.39 in the single market and combined nutrient market, respectively. 
Table 6.37: Average per Unit Cost of Nutrient Reduction from BMPs on Crop and Pasture/Grass Lands

\begin{tabular}{lcccc}
\hline & \multicolumn{2}{c}{ Single market } & \multicolumn{2}{c}{ Combined market } \\
\cline { 2 - 5 } BMP & $\mathrm{TN}(\$ / \mathrm{lb})$. & $\mathrm{TP}(\$ / \mathrm{lb})$. & $\mathrm{TN}(\$ / \mathrm{lb})$. & $\mathrm{TP}(\$ / \mathrm{lb})$. \\
\hline Cover Crop & 17.08 & 51.44 & 15.02 & 6.17 \\
& $(8.38-20.48)$ & $(18.56-67.89)$ & $(7.33-17.88)$ & $(2.22-8.14)$ \\
Grassland & 27.26 & 203 & 23.99 & 14.39 \\
Management & $(23.30-29.14)$ & $(141-238)$ & $(20.51-25.65)$ & $(10.01-16.92)$ \\
\hline
\end{tabular}

Note: values in parenthesis indicate cost range

Potential nutrient credit supplies Scenarios 7 through 9 represent a 1:1 trading ratio, while Scenarios 10 to 12 represent a 2:1 trading ratio. The $100 \%$ nutrient management plan was assumed to be a baseline for all agricultural sources under these six scenarios. Per lb. cost of TN and TP credits were significantly higher with a $100 \%$ nutrient management plan baseline compared to per $\mathrm{lb}$. costs of TN and TP credits with existing BMPs as a baseline requirement. Average per $\mathrm{lb}$. cost of $\mathrm{TN}$ reductions from the prescribed grazing was higher than per lb.TN reduction costs from treatment plant upgrades for some WWTPs (Table 9 and 10).

Although per $\mathrm{lb}$. costs of TN and TP reductions from cover crop BMPs was lower than per lb. costs of TN and TP reductions from prescribed grazing BMPs, nutrient reduction from $100 \%$ cover crop BMPs cannot meet WWTPs TN and TP reduction credit requirements in the watershed. Nutrient trading would not be feasible for some WWTPs in the watershed whose low per lb. average cost of additional reductions precludes their interest in purchasing credits. However, a combined nutrient market, which dramatically lowers average per lb. costs for pasture/grassland BMPs, creates a feasible WQT market for more WWTPs in the watershed.

\subsection{NET ECONOMIC BENEFIT FROM WQT PROGRAM}

All graphs of potential demand and supply curves for the 12 scenarios under a single nutrient market (TP market) and combined nutrients market (TP and $\mathrm{TN}$ ) are presented in 
Appendix C. This section presents the numerical estimation of net economic benefits under the 12 different scenarios in the single and combined nutrients markets.

All 12 scenarios were grouped into three categories based on TP limitations for the WWTPs in the watershed. Table 6.38 presents the net economic benefits under different baseline requirements and trading ratios at $1.0 \mathrm{mg} / \mathrm{l} \mathrm{TP}$ standard in single and combined nutrients markets. Total annual treatment plant upgrade cost to meet $1.0 \mathrm{mg} / \mathrm{l} \mathrm{TP}$ standard for all WWTPs without a WQT market was $\$ 1,798,015$. The net annual economic benefits under all scenarios were higher in a single nutrient market than in a combined nutrients market. The combined nutrients market does not generate positive economic benefit under the existing BMPs baseline requirement and 2:1 trading ratio (scenario 4), and all scenarios under the nutrient management plan baseline requirement (scenario 7 and 10) at $1.0 \mathrm{mg} / 1 \mathrm{TP}$ standard for WWTPs.

Phosphorus trading in a single market at 1:1 trading ratio and existing baseline requirement (scenario 1) generates highest net annual economic benefits at $1.0 \mathrm{mg} / \mathrm{l} \mathrm{TP}$ standard. In all four scenarios from Table 6.38, the existence of a market (either single or combined) generates net annual economic benefits that are greater (even if negative) than the total annual cost to upgrade WWTP. The WQT scenario 10 (nutrient management plan baseline requirement for agricultural sources and 2:1 trading ratio at $1.0 \mathrm{mg} / \mathrm{l} \mathrm{TP}$ standard) does not generate economic benefit in either the single and combined nutrient market.

Table 6.38: Net Economic Benefit at $1.0 \mathrm{mg} / 1 \mathrm{TP}$ Standard in Single and Combined Markets

\begin{tabular}{|c|c|c|c|}
\hline $\begin{array}{c}\text { WQT } \\
\text { Scenario }\end{array}$ & $\begin{array}{c}\text { Net Annual } \\
\text { Economic Benefit: } \\
\text { Single Market (\$) }\end{array}$ & $\begin{array}{c}\text { Net Annual } \\
\text { Economic Benefit: } \\
\text { Combined Market (\$) }\end{array}$ & $\begin{array}{c}\text { Total Annual Upgrade Cost to Meet } \\
1.0 \mathrm{mg} / 1 \text { TP for all WWTPs without } \\
\text { a WQT Market (\$) }\end{array}$ \\
\hline 1 & $1,219,197$ & 337,700 & $-1,798,015$ \\
\hline 4 & 504,738 & $-340,615$ & $-1,798,015$ \\
\hline 7 & 708,088 & $-312,651$ & $-1,798,015$ \\
\hline 10 & $-259,673$ & $-714,251$ & $-1,798,015$ \\
\hline
\end{tabular}


Table 6.39 presents the net economic benefits under different baseline requirements and trading ratios at $0.5 \mathrm{mg} / \mathrm{l} \mathrm{TP}$ standard in single and combined markets. Total annual treatment plant upgrade cost was $\$ 2,432,254$ to meet $0.5 \mathrm{mg} / \mathrm{l}$ TP standard for all WWTPs without a WQT market. Similar to $1.0 \mathrm{mg} / 1 \mathrm{TP}$ standard, the net annual economic benefits under all scenarios were higher in a single nutrient market than in a combined nutrients market and markets generated more benefits than no markets. The combined nutrients market cannot generate any economic benefit under the existing BMPs baseline requirement and 2:1 trading ratio (scenario 5), and all scenarios under the nutrient management plan baseline requirement (scenario 8 and 11) at $0.5 \mathrm{mg} / \mathrm{l} \mathrm{TP}$ standard for WWTPs.

Phosphorus trading in a single market at 1:1 trading ratio and existing baseline requirement (scenario 2) generates highest net annual economic benefits at $0.5 \mathrm{mg} / \mathrm{lP}$ standard. The WQT scenario 11 (nutrient management plan baseline requirement for agricultural sources and 2:1 trading ratio at $0.5 \mathrm{mg} / 1 \mathrm{TP}$ standard) cannot generate economic benefit in both single and combined nutrient markets.

Table 6.39: Net Economic Benefit at $0.5 \mathrm{mg} / \mathrm{l}$ TP Standard in Single and Combined Markets

\begin{tabular}{|c|c|c|c|}
\hline $\begin{array}{c}\text { WQT } \\
\text { Scenario }\end{array}$ & $\begin{array}{c}\text { Net Annual } \\
\text { Economic Benefit: } \\
\text { Single Market (\$) }\end{array}$ & $\begin{array}{c}\text { Net Annual } \\
\text { Economic Benefit: } \\
\text { Combined Market }(\$)\end{array}$ & $\begin{array}{c}\text { Total Annual Upgrade Cost to Meet } \\
0.5 \mathrm{mg} / \text { TP for all WWTPs without } \\
\text { a WQT Market }(\$)\end{array}$ \\
\hline 2 & $1,452,580$ & 128,600 & $-2,432,254$ \\
\hline 5 & 53,893 & $-280,730$ & $-2,432,254$ \\
\hline 8 & 384,443 & $-930,469$ & $-2,432,254$ \\
\hline 11 & $-697,230$ & $-1,833,771$ & $-2,432,254$ \\
\hline
\end{tabular}

Table 6.40 presents the net economic benefits under different baseline requirements and trading ratios at $0.1 \mathrm{mg} / \mathrm{lP}$ standard in single and combined markets. Total annual treatment plant upgrade cost was $\$ 5,495,651$ to meet $0.1 \mathrm{mg} / \mathrm{l}$ TP standard for all WWTPs without a WQT market. Unlike $1.0 \mathrm{mg} / 1$ and $0.5 \mathrm{mg} / 1 \mathrm{TP}$ standards, the combined nutrient market generates 
higher economic benefits than a single market under scenarios 9 and 12 with a nutrient management plan baseline requirement for agricultural sources. The net economic benefits were higher in a single nutrient market under the existing BMPs baseline requirement for agricultural sources. The single nutrient market generates negative economic benefits under the nutrient management plan baseline requirement and 2:1 trading ratio (scenario 12) at $0.1 \mathrm{mg} / \mathrm{l} \mathrm{TP}$ standard for WWTPs. Similar to Tables 6.38 and 6.39, markets generate more economic benefits than no market. Phosphorus trading in a single market at 1:1 trading ratio and existing baseline requirement (scenario 3) generates highest net annual economic benefits at $0.1 \mathrm{mg} / \mathrm{l} \mathrm{TP}$ standard.

Table 6.40: Net Economic Benefit at $0.1 \mathrm{mg} / \mathrm{l} \mathrm{TP}$ Standard in Single and Combined Market

\begin{tabular}{|c|c|c|c|}
\hline $\begin{array}{c}\text { WQT } \\
\text { Scenario }\end{array}$ & $\begin{array}{c}\text { Net Annual } \\
\text { Economic Benefit } \\
\text { Single Market }(\$)\end{array}$ & $\begin{array}{c}\text { Net Annual } \\
\text { Economic Benefit } \\
\text { combined Market (\$) }\end{array}$ & $\begin{array}{c}\text { Total Annual Upgrade Cost to Meet } \\
1.0 \mathrm{mg} / \mathrm{l} \text { TP for all WWTPs without } \\
\text { a WQT Market (\$) }\end{array}$ \\
\hline 3 & $4,917,950$ & $1,924,950$ & $-5,495,651$ \\
\hline 6 & $3,740,972$ & $2,073,449$ & $-5,495,651$ \\
\hline 9 & 264,723 & $2,133,127$ & $-5,495,651$ \\
\hline 12 & $-1,432,780$ & $1,671,977$ & $-5,495,651$ \\
\hline
\end{tabular}

Results in Tables 6.38, 6.39, and 6.40 show that baseline requirement for agricultural sources, effluent limitations for WWTPs, trading ratios between agricultural sources and WWTPs, and market type. The net economic benefits decrease under the nutrient management plan baseline requirements compared to the total net economic benefits under existing BMPs baseline requirements for agricultural sources. The high trading ratio had negative impact on the total net economic benefit. The comparisons of total net economic benefits between 1:1 and 2:1 trading ratios show that the total net economic benefits was always lower at 2:1 trading ratio in the single nutrient market. 


\subsection{SINGLE AND COMBINED NUTRIENTS MARKETS FOR WWTP}

The nutrient reduction costs estimation in a single (TP standard) and a combined nutrients market (combined TN/TP standards) presented in sections 6.4.2, 6.5.1, and 6.5.2 show that per unit costs of nutrient reductions were substantially lower in the combined nutrients market than in the single nutrient market. This section compares the total costs of facility upgrade and total costs of credit purchase for both single and multiple nutrients standards for individual WWTP in the Greenbrier River watershed. From this comparison, this section illustrates that whether a single nutrient standard or multiple nutrients standard are cost effective for individual WWTP in the watershed. Total cost of treatment facility upgrades and total cost of credit purchase in single nutrient market and combined nutrients market were compares for seven individual WWTPs in the watershed.

According to upstream-only trading rule each WWTP must purchase credits from the sellers in the upstream and credit purchases from the sellers in the downstream are not allowed. The analysis in this section estimates total costs of credit purchase for seven significant WWTPs in TP market and TP and TN markets under 12 WQT scenarios (Table 12). Each scenario differs according to the effluent limit, trading ratio, and baseline requirements for agricultural sources. The equilibrium market price in each scenario was used to estimate the total cost of nutrient credit purchase for individual WWTP. The point of intersection of potential demand and supply curves gives the equilibrium market price (see Appendix C for graphs). In some scenarios (i.e. TP trading in a single nutrient market under scenario 3, TP trading in a combined nutrients market under scenario $1,2,3,6,9$, and 12 , and $\mathrm{TN}$ trading in a combined nutrients market under scenario 1, 2, 3, and 4), all WWTPs can purchase nutrient credits at the cost lower than their average per unit cost of nutrient reduction. In this analysis, a potential market price was 
considered at the point where potential demand and/or supply curve becomes vertical line and intersect each other. Table 6.41 presents the equilibrium and potential nutrient credit price in the different WQT scenarios. Combined market prices for phosphorus are substantially below single market prices in each scenario.

Table 6.41: Equilibrium Nutrient Credit Prices for the 12 WQT Scenarios

\begin{tabular}{lccc}
\hline \multirow{2}{*}{ WQT Scenario } & Single Nutrient Market & \multicolumn{2}{c}{ Combined Nutrient Market } \\
\cline { 2 - 4 } & Phosphorus $(\$ / \mathrm{lb})$. & Phosphorus $(\$ / \mathrm{lb})$. & Nitrogen $(\$ / \mathrm{lb})$. \\
\hline 1 & 52.0 & 11.7 & 11.0 \\
2 & 56.0 & 13.0 & 10.0 \\
3 & 74.0 & 53.0 & 14.0 \\
4 & 98.0 & 13.0 & 18.0 \\
5 & 96.0 & 14.0 & 18.5 \\
6 & 116.0 & 48.0 & 18.5 \\
7 & 111.0 & 55.0 & 16.5 \\
8 & 107.5 & 52.0 & 43.9 \\
9 & 198.0 & 46.0 & 43.5 \\
10 & 116.0 & 41.0 & 48.0 \\
11 & 171.0 & 35.0 & 48.0 \\
12 & 239.0 & 35.0 & 43.0 \\
\hline
\end{tabular}

\subsubsection{PENCE SPRINGS PSD}

The Pence Springs PSD is located at Greenbrier 1 sub-watershed in Summers County. This PSD owns and operates a NPDES permitted a Publicly Owned Treatment Works (POTW) facility for sewage treatment. This facility has a 0.48 MGD design flow capacity. The estimated daily TN and TP loads were $32.56 \mathrm{lb}$. and $16.09 \mathrm{lb}$. with $15.88 \mathrm{mg} / \mathrm{l} \mathrm{TN}$ and $4.02 \mathrm{mg} / \mathrm{l} \mathrm{TP}$ concentrations, respectively (EPA 2010). This facility requires upgrading to its treatment system to meet all effluent limits considered in this study. Estimated credit demands for TP at $1.0 \mathrm{mg} / \mathrm{l}$, $0.5 \mathrm{mg} / \mathrm{l}$, and $0.1 \mathrm{mg} / 1 \mathrm{TP}$ limits were 4,410 lb., 5,141 lb. and 5,726 lb., respectively. Estimated credit demands for TN at $8.0 \mathrm{mg} / \mathrm{l}, 5.0 \mathrm{mg} / \mathrm{l}$, and $3.0 \mathrm{mg} / \mathrm{l} \mathrm{TN}$ limits were $186 \mathrm{lb}$., 4,572 lb., and 7,496 lb., respectively. 
Table 6.42 presents annual cost of treatment facility upgrade to different TP limits, cost of credit purchase in a single nutrient market and cost of credit purchase in a combined nutrients market for the Pence Spring PSD at different trading ratios, and baseline requirements for agricultural sources. The phosphorus trading between agricultural sources and Pence Spring PSD in a single nutrient market would not be economically feasible except in one scenario. The phosphorus trading was feasible only under the WQT Scenario 3.

Table 6.42: Cost of Treatment Facility Upgrade to meet TP Limits and Cost of Credits Purchase in Single Nutrient Market and Combined Nutrients Market for Pence Spring PSD

\begin{tabular}{cccc}
\hline $\begin{array}{c}\text { WQT } \\
\text { Scenario }\end{array}$ & $\begin{array}{c}\text { Cost of Treatment } \\
\text { Facility Upgrade to Meet } \\
\text { TP limit (\$/year) }\end{array}$ & $\begin{array}{c}\text { Cost of TP Credits } \\
\text { Purchase (\$/year) in } \\
\text { Single market }\end{array}$ & $\begin{array}{c}\text { Cost of TP and TN Credits } \\
\text { Purchase (\$/year) in } \\
\text { combined market }\end{array}$ \\
\hline 1 & 194,053 & 229,320 & 53,643 \\
2 & 254,120 & 287,896 & 112,553 \\
3 & 544,678 & 423,724 & 408,422 \\
4 & 194,053 & 432,180 & 60,678 \\
5 & 254,120 & 493,536 & 156,556 \\
6 & 544,678 & 664,216 & 413,524 \\
7 & 194,053 & 489,510 & 245,619 \\
8 & 254,120 & 552,658 & 468,043 \\
9 & 544,678 & $1,133,748$ & 589,472 \\
10 & 194,053 & 511,560 & 189,738 \\
11 & 254,120 & 879,111 & 399,391 \\
12 & 544,678 & $1,368,514$ & 522,738 \\
\hline
\end{tabular}

Under this scenario, Pence Spring PSD can save about $22 \%$ of its total cost of treatment facility upgrade. WQT Scenarios 1, 2 and 3 under were economically feasible for Pence Springs PSD in a combined nutrients market. For a 2:1 trading ratio, only WQT Scenarios 6 and 12 were feasible. Scenarios 7 to 11 under a $100 \%$ NMP baseline requirement were not economically feasible for this WWTP. 


\subsubsection{UNION PSD}

Union PSD is located at Greenbrier 1 sub-watershed in Monroe County. This PSD owns and operates a NPDES permitted POTW facility for sewage treatment discharge. This facility has a 2.5 MGD design flow capacity. The estimated daily TN and TP loads were $13.98 \mathrm{lb}$. and $2.0 \mathrm{lb}$. with $16.22 \mathrm{mg} / \mathrm{l} \mathrm{TN}$ and $2.23 \mathrm{mg} / 1 \mathrm{TP}$ concentrations, respectively (EPA 2010). This facility also requires upgrading its treatment system to meet all effluent limits considered in this study. Estimated credit demands for TP at $1.0 \mathrm{mg} / 1,0.5 \mathrm{mg} / \mathrm{l}$, and $0.1 \mathrm{mg} / \mathrm{l}$ effluent limits were 3,153 lb., 3,884 lb. and 4,372 lb., respectively. Estimated credit demand for TN at $8.0 \mathrm{mg} / \mathrm{l}, 5.0$ $\mathrm{mg} / \mathrm{l}$, and $3.0 \mathrm{mg} / \mathrm{TN}$ limits were 3,153 lb., 3,884 lb., and 4,372 lb., respectively.

Table 6.43 presents annual cost of treatment facility upgrade to different TP limits, cost of credit purchase in a single nutrient market and cost of credit purchase in a combined nutrients market for the Union PSD at different trading ratios, and baseline requirements for agricultural sources. The results show that all WQT scenarios were economically feasible for the phosphorus trading between agricultural sources and the Union PSD. This facility can save substantial proportions of its treatment plant upgrade costs from participation in a WQT market. All scenarios under combined nutrients market were economically feasible compared to the cost of treatment facility upgrade to meet TP limits. However, only three scenarios (3, 6 and 12) had lower cost than single nutrient market for the Union PSD. 
Table 6.43: Cost of Treatment Facility Upgrade to meet TP Limits and Cost of Credits Purchase in Single Nutrient Market and Combined Nutrients Market for Union PSD

\begin{tabular}{lccc}
\hline $\begin{array}{l}\text { WQT } \\
\text { Scenario }\end{array}$ & $\begin{array}{c}\text { Cost of Treatment } \\
\text { Facility Upgrade to Meet } \\
\text { TP limit (\$/year) }\end{array}$ & $\begin{array}{c}\text { Cost of TP Credits } \\
\text { Purchase (\$/year) in } \\
\text { Single market }\end{array}$ & $\begin{array}{c}\text { Cost of TP and TN Credits } \\
\text { Purchase (\$/year) in } \\
\text { combined market }\end{array}$ \\
\hline 1 & 374,706 & 25,272 & 40,369 \\
2 & 533,265 & 34,048 & 46,744 \\
3 & $1,463,947$ & 52,244 & 98,626 \\
4 & 374,706 & 47,628 & 63,072 \\
5 & 533,265 & 58,368 & 80,366 \\
6 & $1,463,947$ & 81,896 & 114,770 \\
7 & 374,706 & 53,946 & 78,755 \\
8 & 533,265 & 65,360 & 202,124 \\
9 & $1,463,947$ & 139,788 & 222,658 \\
10 & 374,706 & 56,376 & 171,270 \\
11 & 533,265 & 103,968 & 207,712 \\
12 & $1,463,947$ & 168,734 & 212,706 \\
\hline
\end{tabular}

\subsubsection{TOWN OF ALDERSON}

The Town of Alderson is located at Greenbrier 2 sub-watershed in Greenbrier County. The town owns and operates a NPDES permitted POTW facility for sewage treatment discharge. This facility has a 0.28 MGD design flow capacity. The estimated daily TN and TP loads were $24.89 \mathrm{lb}$. and $7.62 \mathrm{lb}$. with $11.77 \mathrm{mg} / 1 \mathrm{TN} 2.28 \mathrm{mg} / \mathrm{l} \mathrm{TP}$ concentrations, respectively (EPA 2010). This facility also requires upgrading its treatment system to meet all effluent limits considered in this study. Estimated credit demands for TP at $1.0 \mathrm{mg} / \mathrm{l}, 0.5 \mathrm{mg} / \mathrm{l}$, and $0.1 \mathrm{mg} / 1 \mathrm{effluent}$ limits were 1,930 lb., 2,357 lb. and 2,698 lb., respectively. Estimated credit demand for TN at $8.0 \mathrm{mg} / \mathrm{l}$, $5.0 \mathrm{mg} / \mathrm{l}$, and $3.0 \mathrm{mg} / \mathrm{TN}$ limits were 2,262 lb., 3,117 lb., and 5,554 lb., respectively. Table 6.44 presents annual cost of treatment facility upgrade to different TP limits, cost of credit purchase in a single nutrient market, and cost of credit purchase in a combined nutrients market for the Town of Alderson under the 12 WQT scenarios. 
Table 6.44: Cost of Treatment Facility Upgrade to meet TP Limits and Cost of Credits Purchase in Single Nutrient Market and Combined Nutrients Market for Town of Alderson

\begin{tabular}{cccc}
\hline $\begin{array}{c}\text { WQT } \\
\text { Scenario }\end{array}$ & $\begin{array}{c}\text { Cost of Treatment } \\
\text { Facility Upgrade to Meet } \\
\text { TP limit (\$/year) }\end{array}$ & $\begin{array}{c}\text { Cost of TP Credits } \\
\text { Purchase (\$/year) in } \\
\text { Single market }\end{array}$ & $\begin{array}{c}\text { Cost of TP and TN Credits } \\
\text { Purchase (\$/year) in combined } \\
\text { market }\end{array}$ \\
\hline 1 & 202,061 & 100,360 & 47,463 \\
2 & 253,507 & 131,992 & 61,811 \\
3 & 510,667 & 199,652 & 220,750 \\
4 & 202,061 & 189,140 & 65,806 \\
5 & 253,507 & 226,272 & 90,663 \\
6 & 510,667 & 312,968 & 232,253 \\
7 & 202,061 & 214,230 & 143,473 \\
8 & 253,507 & 253,378 & 259,400 \\
9 & 510,667 & 534,204 & 365,707 \\
10 & 202,061 & 223,880 & 187,706 \\
11 & 253,507 & 403,047 & 232,111 \\
12 & 510,667 & 644,822 & 333,252 \\
\hline
\end{tabular}

The WQT scenarios from 1 to 6 were economically feasible both in single nutrient market and combined nutrient market. The costs of TP and TN credits purchase in a combined market were lower than the cost of TP credits purchase in a single market in all scenarios except scenario 8. These results indicate that all WQT scenarios under the existing BMPs baseline requirement were economically feasible for both TN and TP. The Town of Alderson could achieve large cost savings over its treatment plant upgrade costs by purchasing TP and TN credits in a combined nutrient market.

\subsubsection{CITY OF RONCEVERTE}

The City of Ronceverte is located within Greenbrier 2 sub-watershed in Greenbrier County. The city owns and operates a NPDES permitted POTW facility for sewage treatment discharge. This facility has a 0.97 MGD design flow capacity. The estimated daily TN and TP loads were $143.45 \mathrm{lb}$. and $24.60 \mathrm{lb}$. with $19.65 \mathrm{mg} / \mathrm{l} \mathrm{TN} 3.18 \mathrm{mg} / \mathrm{l} \mathrm{TP}$ concentrations, 
respectively (EPA 2010). This facility also requires upgrading its treatment system to meet all effluent limits considered in this study. Estimated credit demands for TP at $1.0 \mathrm{mg} / \mathrm{l}, 0.5 \mathrm{mg} / \mathrm{l}$, and $0.1 \mathrm{mg} / \mathrm{l}$ effluent limits were 6,024 lb., 7,502 lb. and 8,684 lb., respectively. Estimated credit demand for TN at $8.0 \mathrm{mg} / 1,5.0 \mathrm{mg} / \mathrm{l}$, and $3.0 \mathrm{mg} / \mathrm{l} \mathrm{TN}$ limits were 28,722 lb., 37,586 lb., and 43,495 lb., respectively.

Table 6.45 presents annual cost of treatment facility upgrade to different TP limits, cost of credit purchase in a single nutrient market, and cost of credit purchase in a combined nutrients market for the City of Ronceverte under the 12 WQT scenarios. WQT scenarios 1, 2 and 3 with 1:1 trading ratio were economically feasible. With a 2:1 trading ratio, only WQT Scenario 6 was economically feasible. This facility could save its treatment facility upgrade cost only in the scenario 3 in a combined nutrient market.

Table 6.45: Cost of Treatment Facility Upgrade to meet TP Limits and Cost of Credits Purchase in Single Nutrient Market and Combined Nutrients Market for City of Ronceverte

\begin{tabular}{|c|c|c|c|}
\hline $\begin{array}{l}\text { WQT } \\
\text { Scenario }\end{array}$ & $\begin{array}{c}\text { Cost of Treatment } \\
\text { Facility Upgrade to Meet } \\
\text { TP limit (\$/year) }\end{array}$ & $\begin{array}{l}\text { Cost of TP Credits } \\
\text { Purchase (\$/year) in } \\
\text { Single market }\end{array}$ & $\begin{array}{c}\text { Cost of TP and TN Credits } \\
\text { Purchase (\$/year) in combined } \\
\text { market }\end{array}$ \\
\hline 1 & 322,859 & 313,248 & 386,423 \\
\hline 2 & 470,246 & 420,112 & 473,386 \\
\hline 3 & $1,113,949$ & 642,616 & $1,069,182$ \\
\hline 4 & 322,859 & 590,352 & 595,308 \\
\hline 5 & 470,246 & 720,192 & 800,369 \\
\hline 6 & $1,113,949$ & $1,007,344$ & $1,221,490$ \\
\hline 7 & 322,859 & 668,664 & 805,233 \\
\hline 8 & 470,246 & 806,465 & $2,040,129$ \\
\hline 9 & $1,113,949$ & $1,719,432$ & $2,291,497$ \\
\hline 10 & 322,859 & 698,784 & $1,625,640$ \\
\hline 11 & 470,246 & $1,282,842$ & $2,066,698$ \\
\hline 12 & $1,113,949$ & $2,075,476$ & $2,174,225$ \\
\hline
\end{tabular}




\subsubsection{CITY OF WHITE SULFUR SPRINGS}

The City of White Sulfur Springs is located on the Howard Creek sub-watershed in Greenbrier County. The city owns and operates a NPDES permitted POTW facility for sewage treatment discharge. This facility has a 1.31 MGD design flow capacity. The estimated daily TN and TP loads were $53.08 \mathrm{lb}$. and $18.67 \mathrm{lb}$. with $7.22 \mathrm{mg} / \mathrm{l} \mathrm{TN} 2.18 \mathrm{mg} / \mathrm{l} \mathrm{TP}$ concentrations, respectively (EPA 2010). This facility requires upgrading its treatment system to meet $5.0 \mathrm{mg} / \mathrm{l}$ and $3.0 \mathrm{mg} / \mathrm{l} \mathrm{TN}$ limits and all TP limits considered in this study. This facility already meets the $8.0 \mathrm{mg} / \mathrm{l}$ effluent standard for TN. Estimated credit demands for TP at $1.0 \mathrm{mg} / \mathrm{l}, 0.5 \mathrm{mg} / \mathrm{l}$, and $0.1 \mathrm{mg} / \mathrm{l}$ effluent limits were 2,824 lb., 4,819 lb. and 6,416 lb., respectively. Estimated credit demands for TN at $5.0 \mathrm{mg} / \mathrm{l}$, and $3.0 \mathrm{mg} / \mathrm{l} \mathrm{TN}$ limits were 10,340 lb. and 18,324 lb., respectively.

Table 6.46 presents annual cost of treatment facility upgrade to different TP limits, cost of credit purchase in a single nutrient market, and cost of credit purchase in a combined nutrients market. Under an existing BMPs baseline requirement, results show that all WQT scenarios were economically feasible both in a single nutrient market and combined nutrient market. Under a 100\% NMP baseline requirement, only WQT Scenario 7 and 10 was economically feasible in a single nutrient market and scenario 7, 10, and 12 in a combined nutrient market. All other WQT scenarios for TP credits trading under the 100\% NMP baseline requirement were not feasible as treatment costs were lower than cost of credit purchases. 
Table 6.46: Cost of Treatment Facility Upgrade to meet TP Limits and Cost of Credits Purchase in Single Nutrient Market and Combined Nutrients Market for City of White Sulfur Spring

\begin{tabular}{lccc}
\hline $\begin{array}{l}\text { WQT } \\
\text { Scenario }\end{array}$ & $\begin{array}{c}\text { Cost of Treatment Facility } \\
\text { Upgrade to Meet TP limit } \\
(\$ / \text { year) }\end{array}$ & $\begin{array}{c}\text { Cost of TP Credits } \\
\text { Purchase }(\$ / \text { year) in } \\
\text { Single market }\end{array}$ & $\begin{array}{c}\text { Cost of TP and TN Credits } \\
\text { Purchase (\$/year) in } \\
\text { combined market }\end{array}$ \\
\hline 1 & 316,700 & 146,848 & 33,041 \\
2 & 456,441 & 269,864 & 166,047 \\
3 & $1,099,483$ & 474,784 & 596,528 \\
4 & 316,700 & 276,752 & 36,712 \\
5 & 456,441 & 462,624 & 258,756 \\
6 & $1,099,483$ & 744,256 & 646,888 \\
7 & 316,700 & 313,464 & 155,320 \\
8 & 456,441 & 518,043 & 704,514 \\
9 & $1,099,483$ & $1,270,368$ & $1,092,056$ \\
10 & 316,700 & 327,584 & 115,784 \\
11 & 456,441 & 824,049 & 664,985 \\
12 & $1,099,483$ & $1,533,424$ & $1,012,320$ \\
\hline
\end{tabular}

\subsubsection{TOWN OF HILLSBORO}

The Town of Hillsboro is located within Greenbrier 3 sub-watershed in Greenbrier County. This town owns and operates a NPDES permitted POTW facility for sewage treatment discharge. This facility has a 0.064 MGD design flow capacity. The estimated daily TN and TP loads were $5.28 \mathrm{lb}$. and $3.42 \mathrm{lb}$. with $19.15 \mathrm{mg} / \mathrm{l} \mathrm{TN} 2.95 \mathrm{mg} / \mathrm{l} \mathrm{TP}$ concentrations, respectively (EPA 2010). This facility also requires upgrading its treatment system to meet all effluent limits considered in this study. Estimated credit demands for TP at $1.0 \mathrm{mg} / 1,0.5 \mathrm{mg} / \mathrm{l}$, and $0.1 \mathrm{mg} / 1$ effluent limits were 1,052 lb., 1,149 lb. and 1,227 lb., respectively. Estimated credit demand for $\mathrm{TN}$ at $8.0 \mathrm{mg} / \mathrm{l}, 5.0 \mathrm{mg} / \mathrm{l}$, and $3.0 \mathrm{mg} / \mathrm{l} \mathrm{TN}$ limits were $367 \mathrm{lb} ., 951 \mathrm{lb}$, and 1,341 lb., respectively.

Table 6.47 presents annual cost of treatment facility upgrade to different TP limits, cost of credit purchase in a single nutrient market, and cost of credit purchase in a combined nutrients 
market for the Town of Hillsboro under the 12 WQT scenarios. All 12 WQT scenarios were economically feasible. However, this facility can save more cost from the participation in a combined nutrients market compared to the cost saving in a single nutrient market.

Table 6.47: Cost of Treatment Facility Upgrade to meet TP Limits and Cost of Credits Purchase in Single Nutrient Market and Combined Nutrients Market for Town of Hillsboro

\begin{tabular}{cccc}
\hline $\begin{array}{c}\text { WQT } \\
\text { Scenario }\end{array}$ & $\begin{array}{c}\text { Cost of Treatment Facility } \\
\text { Upgrade to Meet TP limit } \\
(\$ / \text { year) }\end{array}$ & $\begin{array}{c}\text { Cost of TP Credits } \\
\text { Purchase }(\$ / \text { year) in } \\
\text { Single market }\end{array}$ & $\begin{array}{c}\text { Cost of TP and TN Credits } \\
\text { Purchase (\$/year) in } \\
\text { combined market }\end{array}$ \\
\hline 1 & 173,299 & 54,704 & 16,345 \\
2 & 192,616 & 64,344 & 24,447 \\
3 & 280,555 & 90,798 & 83,805 \\
4 & 173,299 & 103,096 & 20,282 \\
5 & 192,616 & 110,304 & 33,680 \\
6 & 280,555 & 142,332 & 83,705 \\
7 & 173,299 & 116,772 & 63,916 \\
8 & 192,616 & 123,518 & 101,497 \\
9 & 280,555 & 242,946 & 114,776 \\
10 & 173,299 & 122,032 & 60,748 \\
11 & 192,616 & 196,479 & 85,863 \\
12 & 280,555 & 293,253 & 100,608 \\
\hline
\end{tabular}

\subsubsection{CITY OF MARLINTON}

The City of Marlinton is located within the Knapp Creek sub-watershed in Greenbrier County. Marlinton owns and operates a NPDES permitted POTW facility for sewage treatment discharge. This facility has a 0.21 MGD design flow capacity. The estimated daily TN and TP loads were $25.05 \mathrm{lb}$. and $3.31 \mathrm{lb}$. with $10.21 \mathrm{mg} / \mathrm{TN} 1.57 \mathrm{mg} / \mathrm{TP}$ concentrations, respectively (EPA 2010). This facility also requires upgrading its treatment system to meet all effluent limits considered in this study. Estimated credit demands for TP at $1.0 \mathrm{mg} / 1,0.5 \mathrm{mg} / 1$, and $0.1 \mathrm{mg} / 1$ effluent limits were 532 lb., 852 lb. and 1,108 lb., respectively. Estimated credit demand for TN at $8.0 \mathrm{mg} / \mathrm{l}, 5.0 \mathrm{mg} / \mathrm{l}$, and $3.0 \mathrm{mg} / \mathrm{l} \mathrm{TN}$ limits were 4,026 lb., 5,945 lb., and 7,224 lb., respectively. 
Table 6.48 presents annual cost of treatment facility upgrade to different TP limits, cost of credit purchase in a single nutrient market, and cost of credit purchase in a combined nutrients market for the City of Marlinton under the 12 WQT scenarios.

Table 6.48: Cost of Treatment Facility Upgrade to meet TP Limits and Cost of Credits Purchase in Single Nutrient Market and Combined Nutrients Market for City of Marlinton

\begin{tabular}{lccc}
\hline $\begin{array}{l}\text { WQT } \\
\text { Scenario }\end{array}$ & $\begin{array}{c}\text { Cost of Treatment } \\
\text { Facility Upgrade to Meet } \\
\text { TP limit (\$/year) }\end{array}$ & $\begin{array}{c}\text { Cost of TP Credits } \\
\text { Purchase (\$/year) in } \\
\text { Single market }\end{array}$ & $\begin{array}{c}\text { Cost of TP and TN Credits } \\
\text { Purchase (\$/year) in } \\
\text { combined market }\end{array}$ \\
\hline 1 & 214,337 & 27,664 & 50,510 \\
2 & 272,059 & 47,712 & 70,526 \\
3 & 482,372 & 81,992 & 159,860 \\
4 & 214,337 & 52,136 & 79,384 \\
5 & 272,059 & 81,792 & 121,911 \\
6 & 482,372 & 128,528 & 186,828 \\
7 & 214,337 & 59,052 & 95,689 \\
8 & 272,059 & 91,590 & 305,290 \\
9 & 482,372 & 219,384 & 365,212 \\
10 & 214,337 & 61,712 & 215,060 \\
11 & 272,059 & 145,692 & 315,180 \\
12 & 482,372 & 264,812 & 349,412 \\
\hline
\end{tabular}

Results show that under all 12 WQT scenarios, trading of TP credits was economically feasible both in a single nutrient market and in a combined nutrient market. However, this facility can save more cost from the participation in a single nutrient market compared to the cost saving in a combined nutrients market. This facility can save more cost only under the scenario 6 and 12 in a combined nutrients market than in a single nutrient market.

\subsection{WQT UNDER THE PROPOSED TP STANDARD BY WVDEP}

The WVDEP has proposed $0.5 \mathrm{mg} / \mathrm{l}$ TP standard for the WWTPs in the Greenbrier River watershed considering TP as a main cause of algal blooms in the Greenbrier River. However, the WVDEP has not proposed any TN standards for the WWTPs in the watershed. This study considered $0.5 / \mathrm{mg}$ TP for single standard and $0.5 \mathrm{mg} / 1 \mathrm{TP}$ and $5.0 \mathrm{mg} / \mathrm{l} \mathrm{TN}$ for multiple nutrients 
standard. Table 6.49 presents total compliance cost of WWTPs upgrades and total cost in a single market of compliance TP for individual WWTPs in single nutrient standard (0.5 mg/l TP) under two baseline requirements for agricultural non-point sources and two trading ratios $(1: 1$ and 2:1). The total compliance cost for all seven WWTP upgrades to meet $0.5 \mathrm{mg} / 1 \mathrm{TP}$ standard in the absence of WQT market was $\$ 2,432,254$ per year. The percentage of cost savings from the participation in a single market in the watershed ranged from $1 \%$ to $48 \%$. Average cost saving was negative under the nutrient management plan baseline requirement and 2:1 trading ratio.

Table 6.49: Compliance Costs for WWTP Upgrades and Cost in a Single Market of Compliance TP

\begin{tabular}{|c|c|c|c|c|c|}
\hline \multirow[t]{4}{*}{ WWTP } & \multirow{4}{*}{$\begin{array}{c}\text { No WQT Market } \\
\text { Compliance Costs for } \\
\text { WWTP Upgrades to } \\
\text { Meet a TP Standard (\$) }\end{array}$} & \multicolumn{4}{|c|}{ WQT Market for TP } \\
\hline & & \multicolumn{4}{|c|}{ Total Cost in a Single Market to Purchase TP (\$) } \\
\hline & & \multicolumn{2}{|c|}{ Baseline: Current BMPs } & \multicolumn{2}{|c|}{ Baseline: NMP } \\
\hline & & $1: 1$ & $2: 1$ & $1: 1$ & $2: 1$ \\
\hline Town of Alderson & 253,507 & 131,992 & 226,272 & 253,378 & 403,047 \\
\hline City of Ronceverte & 470,246 & 420,112 & 720,192 & 806,465 & $1,282,842$ \\
\hline Union PSD & 533,265 & 34,048 & 58,368 & 65,360 & 103,968 \\
\hline Pence Springs & 254,120 & 287,896 & 493,536 & 552,658 & 879,111 \\
\hline City of White Sulfur & & & & & \\
\hline Springs & 456,441 & 269,864 & 462,624 & 518,043 & 824,049 \\
\hline Town of Hillsboro & 192,616 & 64,344 & 110,304 & 123,518 & 196,479 \\
\hline City of Marlinton & 272,059 & 47,712 & 81,792 & 91,590 & 145,692 \\
\hline Total & $2,432,254$ & $1,255,968$ & $2,153,088$ & $2,411,012$ & $3,835,188$ \\
\hline $\begin{array}{l}\text { Cost Saving from } \\
\text { WQT Market }\end{array}$ & & $48.36 \%$ & $11.47 \%$ & $0.87 \%$ & - \\
\hline
\end{tabular}

The switch from WWTP upgrades to credit purchase from the TP credit market was feasible for many WWTPs. The total cost of compliance was lower than total cost of credit purchase in all baseline requirements and trading ratios for Union PSD and City of Marlinton. The total cost of compliance is lower than total cost of credit purchase for all WWTPs except Pence Spring in current BMPs baseline requirement and 1:1 trading ratio. The Town of Alderson and the Town of Hillsboro can purchase TP credits at lower cost than the total cost of 
compliance under both trading ratios in the existing BMPs baseline requirement and under 1:1 trading ratio in the NMP baseline requirement. Nutrient trading under $0.5 \mathrm{mg} / 1 \mathrm{TP}$ standard was not economically feasible for Pence Spring PSD in all baseline requirements and trading ratios.

Table 6.50 presents total compliance cost of WWTP upgrades to meet TP nutrients standard $(0.5 \mathrm{mg} / \mathrm{l} \mathrm{TP})$ and total cost in a combined nutrients market to purchase TP and TN for individual WWTPs under two baseline requirements for agricultural non-point sources and two trading ratios $(1: 1$ and $2: 1)$. The cost savings from the participation in a combined nutrients market in the watershed was about $61 \%$ under the existing BMPs baseline requirement and 1:1 trading ratio. This cost saving was about $37 \%$ under the existing BMPs baseline requirement and 2:1 trading ratio. Average cost saving was negative under the nutrient management plan baseline requirement for the agricultural sources.

Table 6.50: Compliance Costs for WWTP Upgrades and Cost in a Combined Market of Compliance TP and TN

\begin{tabular}{|c|c|c|c|c|c|}
\hline \multirow[t]{4}{*}{ WWTP } & \multirow{4}{*}{$\begin{array}{c}\text { No WQT Market } \\
\text { Compliance Costs for } \\
\text { WWTP Upgrades to } \\
\text { Meet a TP Standard (\$) }\end{array}$} & \multicolumn{4}{|c|}{ WQT Market for TP and TN } \\
\hline & & \multicolumn{4}{|c|}{$\begin{array}{l}\text { Total Cost in a Combined Market to Purchase TP and } \\
\text { TN }\end{array}$} \\
\hline & & \multicolumn{2}{|c|}{ Baseline: Current BMPs } & \multicolumn{2}{|c|}{ Baseline: NMP (\$) } \\
\hline & & $1: 1$ & $2: 1$ & $1: 1$ & $2: 1$ \\
\hline Town of Alderson & 253,507 & 61,811 & 90,663 & 259,400 & 232,111 \\
\hline City of Ronceverte & 470,246 & 473,386 & 800,369 & $2,040,129$ & $2,066,698$ \\
\hline Union PSD & 533,265 & 46,744 & 80,366 & 202,124 & 207,712 \\
\hline Pence Springs & 254,120 & 112,553 & 156,556 & 468,043 & 399,391 \\
\hline \multicolumn{6}{|l|}{ City of White Sulfur } \\
\hline Springs & 456,441 & 166,047 & 258,756 & 704,514 & 664,985 \\
\hline Town of Hillsboro & 192,616 & 24,447 & 33,680 & 101,497 & 85,863 \\
\hline City of Marlinton & 272,059 & 70,526 & 121,911 & 305,290 & 315,180 \\
\hline Total & $2,432,254$ & 955,514 & $1,542,301$ & $4,080,997$ & $3,971,940$ \\
\hline $\begin{array}{l}\text { Cost Saving from } \\
\text { WQT Market }\end{array}$ & & $60.71 \%$ & $36.58 \%$ & - & - \\
\hline
\end{tabular}

Note: Each WWTP was assumed to choose either plant upgrade to meet a TP and TN standard or purchase TP and TN credit from a combined market to minimize cost of compliance

The Union PSD and the Town of Hillsboro can purchase TP and TN credits at lower cost than the total cost of TP and TN credits purchase from a combined nutrients market in all 
baseline requirements and trading ratios. The Town of Alderson, Pence Spring, City of White Sulfur Springs, and City of Marlinton can purchase TP credits at lower cost than the total cost of compliance under both trading ratios in the existing BMPs baseline requirement. Many WWTPs would not save their treatment plant upgrading costs from the participation in a combined nutrients market under the nutrient management plan baseline requirement for agricultural sources.

\subsection{EXISTING BMP, BASELINE REQUIREMENTS, AND WQT MARKET}

This section discusses the potential impacts of existing level of BMPs implemented by the crop and pasture/grass lands owners in the WQT market. The study explores the potential impacts of baseline choice and existing level of BMPS on: amount of nutrient credit generation, cost of credit, and participation of agricultural sources in the WQT market. The analysis includes 112 crop land owners and 66 pasture land owners within five sub-watersheds (Greenbrier1, Second Creek, Muddy Creek, Greenbrier 2, and Spring Creek) of Greenbrier River watershed. The survey respondents represent 3,803 acres crop lands and 9,732 acres pasture/grasslands in the five sub-watersheds.

Table 6.52 presents total number and percentage of farmers who had implemented cover crops, nutrient management plans and prescribed grazing management on their crop and pasture/grassland in the survey area. About $21 \%$ and $29 \%$ farmers had implemented cover crop and nutrient management plan on their crop lands, respectively. Survey results also indicate that $27 \%$ and $48 \%$ pasture land owner had implemented nutrient management plan and prescribed grazing management, respectively. 
Table 6.51: Number and Percentage of Farmers with BMPs in Crop and Pasture/Grass Lands

\begin{tabular}{lll} 
BMP & Crop Land $(\mathrm{n}=112)$ & Pasture/Grassland $(\mathrm{n}=66)$ \\
\hline
\end{tabular}

Cover Crop

Nutrient Management Plan

Prescribed Grazing Management

Survey data provides the land area under each land category, and type and amount of BMPs implementation. This study estimates the current level of cover crop and nutrient management plan on the crop lands, and nutrient management plan and grazing land management on the pasture/grasslands for all respondents based on the survey data. Table 6.53 presents the total area under particular BMP and percent of total respondents land area under particular BMP. About $24 \%$ crop land was under cover crop. The nutrient management plan was implemented in $28 \%$ of the crop lands. The nutrient management plan and prescribed grazing management were implemented in $16 \%$ and $57 \%$ of total pasture/grasslands, respectively.

Table 6.52: Current Level of Selected BMPs in Crop and Pasture/Grass Lands

\begin{tabular}{lcccc}
\hline BMP & \multicolumn{2}{c}{ Crop Land (n = 112) } & \multicolumn{2}{c}{ Pasture/Grassland (n = 66) } \\
\cline { 2 - 5 } & Total Area (acre) & Percent & Total land (acre) & Percent \\
\hline $\begin{array}{l}\text { Cover Crop } \\
\text { Nutrient Management }\end{array}$ & 933 & 24.53 & - & - \\
$\begin{array}{l}\text { Plan } \\
\text { Prescribed Grazing }\end{array}$ & 1,093 & 28.74 & 1,587 & 16.30 \\
Management & - & - & 5,629 & 57.84 \\
\hline
\end{tabular}

\subsubsection{NUTRIENTS CREDITS GENERATION}

The impact of existing level of BMPs and different baseline requirements on individual farm types and nutrient credits generation are discussed in this section. The impact on nutrient credits generation in the watershed depends on the existing level of BMPs and type of baseline requirement for agricultural sources enforced by the regulatory authority. 
Table 6.54 presents the total amount of TN and TP credits generated under two baseline requirements on the 3,803 acres of crop lands and 9,732 acres of pasture/grasslands. Results indicate that the total amount of $\mathrm{TN}$ and $\mathrm{TP}$ credits generated under the $100 \%$ nutrient management plan baseline was lower than the total amount of $\mathrm{TN}$ and $\mathrm{TP}$ credits generated under the existing BMPs baseline requirement. The total amount of TN and TP credits were $17 \%$ and $31 \%$ higher under the existing BMPs baseline than $100 \%$ nutrient management plan baseline. The aggregate supply increases under existing BMPs baseline because farmers who did not implement any BMPs before setting baseline can have more nutrient credit generation actions in crop and pasture/grasslands.

Table 6.53: Supply of Nutrient Credits under Different Baseline Requirements

\begin{tabular}{lcccc}
\hline Baseline & \multicolumn{2}{c}{ Cropland } & \multicolumn{2}{c}{ Pasture and Grassland } \\
\cline { 2 - 5 } & TN & TP & TN & TP \\
\hline $\begin{array}{l}\text { Existing level of } \\
\text { BMPs }\end{array}$ & 15,591 & 5,835 & 23,619 & 4,262 \\
$\begin{array}{l}\text { 100\% nutrient } \\
\text { management plan }\end{array}$ & 11,096 & 4,084 & 21,421 & 2,922 \\
\hline
\end{tabular}

Figures 6.14 and Figure 6.15 represent potential supply curves of TN and TP under two baseline requirements. The figures show that the potential supply curve of TN and TP under the $100 \%$ nutrient management plan baseline lies above the supply curve under the existing BMPs baseline. This indicates that at any price level TN and TP credits were higher under the existing BMPs baseline. 


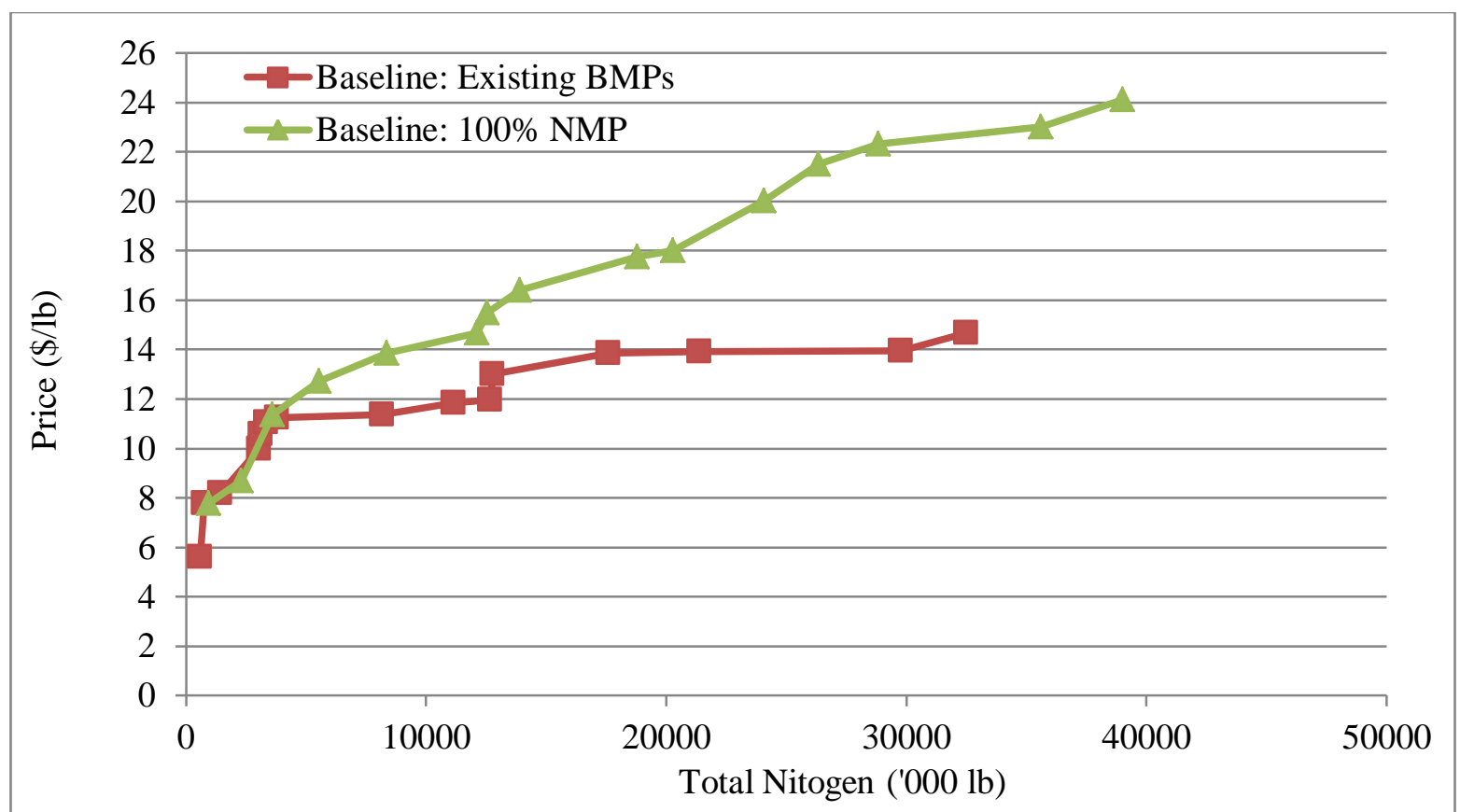

Figure 6.14: Supply of TN under Existing BMPs and 100\% NMP Baseline Requirements

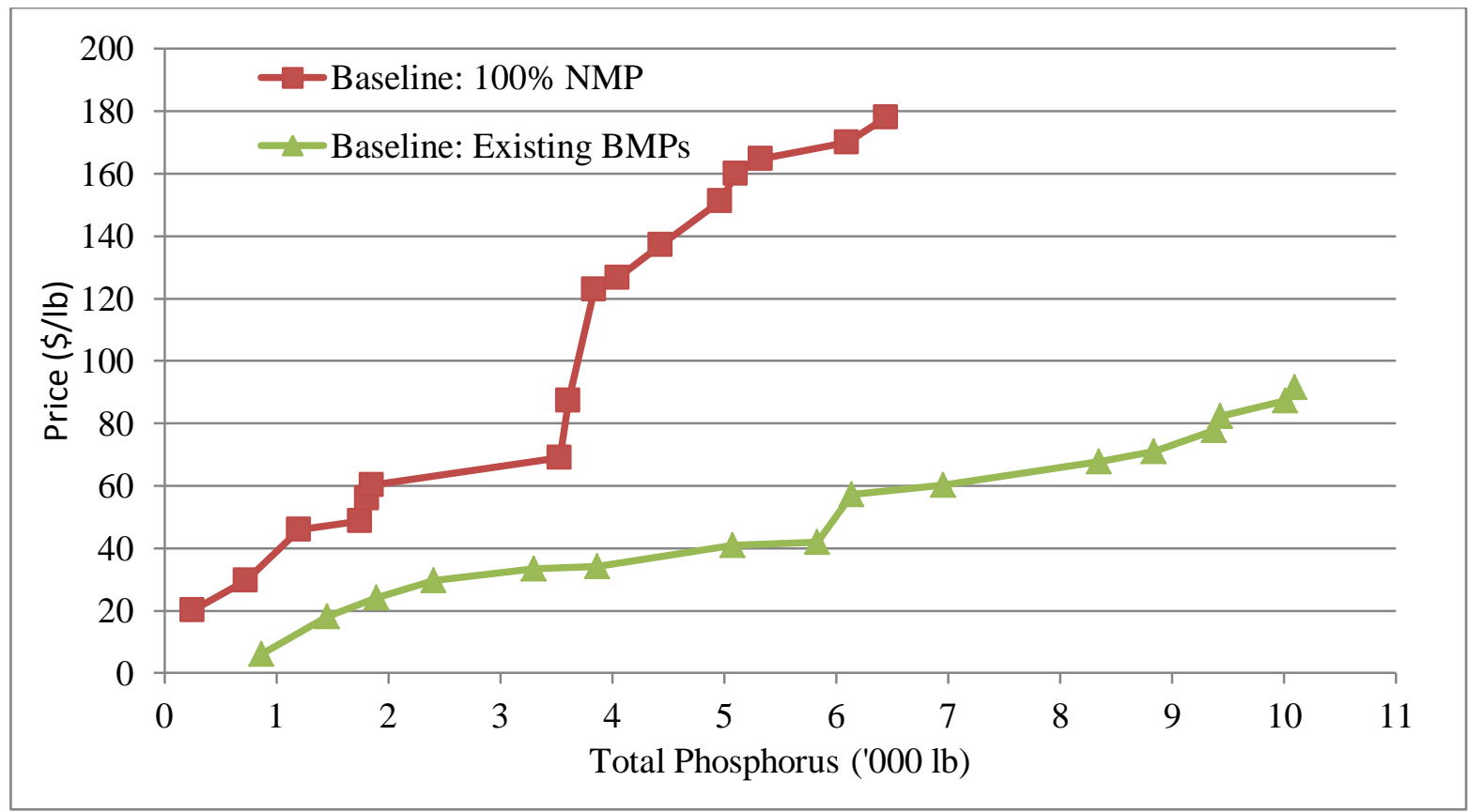

Figure 6.15: Supply of TP under Existing BMPs and 100\% NMP Baseline Requirements

The price of credits for any quantity of agricultural source reduction was higher under the 100\% NMP baseline. The differences between the price of credits under existing BMPs baseline and $100 \%$ NMP baseline increase with the increase in the supply of TN and TP credits. This 
implies that the impact of two baselines on the costs of nutrient credits increases with the increase in the supply of TN and TP credits.

\subsubsection{COST OF NUTRIENT CREDIT GENERATION}

This section discusses the impact of existing BMPs on the cost of nutrient credit generation under two baselines. All farmers were grouped into two groups: Ex-ante BMPs implementers and Ex-post BMPs implementers. Ex-ante BMPs implementers had some level of BMPs under consideration on their crop and pasture/grasslands. All Ex-post BMPs implementers had not implemented any BMPs under consideration. They can potentially generate nutrient credits from the implementation of BMPs on their crop and pasture/grasslands.

Tables 6.55 and 6.56 present average cost of credit generation under different baseline requirements for the crop lands and pasture/grasslands owners. Per unit costs of TN and TP credit generation were significantly higher for ex-ante BMPs implementers than ex-post BMPs implementers under existing BMPs baseline. Under an existing BMPs baseline, average costs of $\mathrm{TN}$ and TP credit generation from the cover crop for ex-ante BMPs implementers were $\$ 53.62$ and \$146.61, respectively. Under similar baseline, average costs of TN and TP credit generation for ex-post BMPs implementers were $\$ 13.10$ and $\$ 36.90$, respectively. Average costs of TN and TP credit generation were a little low from the nutrient management pan in the crop lands.

Table 6.54: Average Cost of Credit Generation under Different Baseline Requirements for the Crop Land Owners

\begin{tabular}{lcccc}
\hline \multirow{2}{*}{ Baseline requirement } & \multicolumn{2}{c}{ Cover Crop } & \multicolumn{2}{c}{ Nutrient Management Plan } \\
\cline { 2 - 5 } & $\mathrm{TN}(\$ / \mathrm{lb})$ & $\mathrm{TP}(\$ / \mathrm{lb})$ & $\mathrm{TN}(\$ / \mathrm{lb})$ & $\mathrm{TP}(\$ / \mathrm{lb})$ \\
\hline Existing level of BMPs & & & & \\
Ex-ante BMPs implementers & 53.62 & 149.61 & 46.74 & 143.65 \\
Ex-post BMPs implementers & 13.10 & 36.90 & 9.47 & 29.34 \\
$100 \%$ NMP & & & & - \\
Ex-ante BMPs implementers & 14.66 & 40.59 & - & - \\
Ex-post BMPs implementers & 21.62 & 60.54 & - & - \\
\hline
\end{tabular}


Under 100\% NMP baseline requirements, ex-ante BMPs implementers of NMP would be at a greater cost advantage than ex-post BMPs implementers. Per unit costs of both TN and TP credit generation were significantly lower for ex-ante BMPs implementers than ex-post BMPs implementers under 100\% NMP baseline. Under 100\% NMP baseline, average costs of TN and TP credit generation from the cover crop for ex-ante BMPs implementers were $\$ 14.66$ and $\$ 40.59$, respectively. Under the same baseline, average costs of TN and TP credit generation for ex-post BMPs implementers were \$21.62 and \$60.54, respectively.

Table 6.55: Average Cost of Credit Generation under Different Baseline Requirements for the Pasture/Grassland Owners

\begin{tabular}{lcccc}
\hline Baseline requirement & \multicolumn{2}{c}{ Prescribed Grazing } & \multicolumn{2}{c}{ Nutrient Management Plan } \\
\cline { 2 - 5 } & $\mathrm{TN}(\$ / \mathrm{lb})$ & $\mathrm{TP}(\$ / \mathrm{lb})$ & $\mathrm{TN}(\$ / \mathrm{lb})$ & $\mathrm{TP}(\$ / \mathrm{lb})$ \\
\hline Existing level of BMPs & & & & \\
Ex-ante BMPs implementers & - & - & 24.23 & 116.95 \\
Ex-post BMPs implementers & 11.61 & 85.06 & 13.55 & 66.01 \\
$100 \%$ NMP & & & & - \\
Ex-ante BMPs implementers & 17.04 & 124.39 & - & - \\
Ex-post BMPs implementers & 22.66 & 167.59 & - & - \\
\hline
\end{tabular}

These results illustrate that the existing BMP baseline would generate substantial benefit for ex-post BMPs implementers whereas the 100\% NMP baseline would be beneficial to ex-ante NMP implementers, as expected. In the pasture/grasslands, ex-ante prescribed grazing management BMP implementers can’t generate more credits. These farmers have implemented prescribed grazing management in their all pasture/grassland areas.

\subsubsection{FARMERS PARTICIPATION IN THE WQT MARKET}

So far the aggregate level of nutrient credits supplies and cost of nutrient credits under two baseline requirements were compared and discussed. The comparison has focused on the relative efficiency of the two baseline requirements for the agricultural sources. This section 
covers a discussion of how existing level of BMPs affects farmer participation in the WQT market.

As discussed in the previous section, the existing level of BMPs and baseline requirements had significant impacts on per unit costs of TN and TP credit generation. High per unit costs of credit generation can significantly reduce the farmer's participation in the WQT market. The existing levels of BMPs on the crop lands and pasture/grasslands and baseline requirements have large impacts on the phosphorus trading in the WQT market. Per unit cost of TP credit generation was more than $\$ 110$ for ex-ante cover crop and nutrient management plan implementers under existing BMPs baseline on the crop lands. Only three WWTPs (Union PSD, Town of Hillsboro, and City of Marlinton) had more than $\$ 110 / \mathrm{lb}$ TP reduction cost in the watershed and can purchase their TP credits with 1:1 trading ratio.

The TP credit generation under $100 \%$ nutrient management plan baseline requirements for pasture/grassland owners was very costly. The average cost of TP credit generation was $\$ 124 / \mathrm{lb}$ and $\$ 164 / \mathrm{lb}$ for ex-ante and ex-post nutrient management plan implementers, respectively. Major TP credit demanders: The Town of Alderson, City of Ronceverte, Pence Springs PSD, and City of White Sulfur Springs, would not purchase TP credits from the agricultural sources in that price levels. This indicates that some farmers would not generate nutrient credits at the price range that WWTPs are willing to pay for. This can eliminate many farmers from the WQT market in the watershed.

The farmer's participation in the WQT market can be affected by the baseline requirement enforced by the regulatory authority. Table 6.57 presents percentages of farmers who would not participate in WQT under existing BMPs baseline requirement for agricultural sources. 
Table 6.56: Percentage of Farmers Who Could Not Participate in a WQT Market

\begin{tabular}{lcc}
\hline Existing BMP & Crop Land Owner & Pasture/Grassland Owner \\
\hline Cover crop & $4.46 \%$ & - \\
Nutrient Management Plan & $6.25 \%$ & $3.03 \%$ \\
Prescribed Grazing & - & $48.48 \%$ \\
\hline
\end{tabular}

Farmers with $100 \%$ coverage of land area by the existing BMPs would not generate any credits to supply in the WQT market under the existing BMPs baseline requirement. About 5\% respondents had implemented cover crop on their all crop land area. Similarly, about $6 \%$ respondents had implemented nutrient management plan on their total crop land area. About 3\% and $48 \%$ had implemented nutrient management plan and prescribed grazing respectively on their all pasture/grasslands. These respondents would not generate any nutrient credit by implementing more cover crop and nutrient management plan on the crop land and nutrient management plan and prescribed grazing on the pasture/grasslands. 


\section{CHAPTER 7: CONCLUSIONS AND POLICY IMPLICATIONS}

\subsection{CONCLUSIONS}

This dissertation reports the results of a water quality trading (WQT) feasibility analysis in the Greenbrier River watershed of West Virginia. The main goal of this study was to assess the physical and economic feasibility of implementing a WQT program which can reduce the nutrient related problems of the Greenbrier River. The focus of this study was on nutrient trading feasibility between waste water treatment plants (WWTPs) and farmers in the watershed. This study provides an estimate of the potential of nutrient credit generation from the agricultural sources and nutrient credit utilization by WWTPs. The costs of nutrient reduction for agricultural sources and WWTPs, total economic benefits from a potential WQT program, and cost savings for individual WWTP were also estimated. This dissertation identifies a potential area for a WQT program under various market design parameters that forms the main prerequisites for a successful implementation in the watershed.

The physical feasibility of WQT analysis includes the estimation of current total nitrogen (TN) and total phosphorus (TP) loadings from point and nonpoint sources, potential of nutrient credit reduction from the agricultural non-point sources, and nutrient reduction requirements for the point sources at different effluent limitations in the watershed. The results of the TN and TP load estimations presented in section 6.3 indicate that the agricultural non-point sources discharge large amounts of TN and TP in the watershed. The estimated cumulative annual agricultural loading from crop and pasture/grasslands was 1,816,144 pounds of $\mathrm{TN}$ and 250,553 pounds of TP which accounts for about $29 \%$ of total nitrogen and $56 \%$ of total phosphorus discharges in the watershed. The estimated average annual nitrogen and phosphorus discharges 
from the point sources (WWTPs) in the Greenbrier River watershed were 212,985 lb. and 43,001 lb. respectively.

The total nutrient reduction potential from the agricultural non-point sources was estimated based on simulation of cover crop and nutrient management plans on crop lands and prescribed grazing and nutrient management plan on pasture/grass lands. The estimation of nutrient reduction potential from the agricultural nonpoint sources under 12 different scenarios are presented in section 6.5 and total estimated TN and TP reduction requirements at different effluent limitations for the WWTPs in the watershed are presented in Table 6.12 (section 6.4). Results show that WWTPs require reducing substantial amounts of nutrient under different effluent limitations. For example, total TP reduction requirements for WWTPs were 17,259 lb., 22,428 lb., and 26,563 lb. of TP at $1.0 \mathrm{mg} / 1,0.5 \mathrm{mg} / \mathrm{l}$, and 0.1 respectively.

The comparisons of nutrient reduction potentials from agricultural non-point sources and nutrient reduction requirements for WWTPs show that there will likely be sufficient supply of TN and TP credits from agriculture sources to meet point source's nutrient reduction requirements. A small percentage of $\mathrm{TN}$ and $\mathrm{TP}$ reduction from the existing agricultural nonpoint sources loadings can easily meet the total nutrient reduction requirements for the WWTPs in the watershed. If 2:1 trading ratio is applied for both $\mathrm{TN}$ and $\mathrm{TP}$ trading, nutrient reductions generated by the four best management practices (BMPs) considered in this study would fully meet WWTPs nutrient reduction needs in the watershed. For example, about a $21 \%$ TP reduction from the existing agricultural non-point source loading would meet the total TP reduction requirement of WWTPs at the most stringent TP limit $(0.1 \mathrm{mg} / \mathrm{l})$ and 2:1 trading ratio. For all the 12 scenarios, the percentage of $\mathrm{TP}$ reduction requirement from the existing agricultural source loadings ranged from $7 \%$ to $21 \%$. Whereas the percentage of $\mathrm{TN}$ reduction requirement from the 
existing agricultural source loading ranged from $2 \%$ to $10 \%$. Thus, these results indicate that agricultural non-point sources have abundant potential for nutrient reduction to meet the nutrient reduction requirements of WWTPs at all effluent limitations.

The economic feasibility of WQT analysis includes the estimation of nutrient reduction costs for agricultural non-point and point sources demand for and supply of nutrient credits, equilibrium market prices, total economic benefits from a potential WQT program, and potential cost savings for individual WWTP. The cost of TP and TN reduction (\$/lb.) from the agricultural sources under the existing BMPs and nutrient management plan baseline requirement are presented in sections 6.5.1 and 6.5.2, respectively. Out of four BMPs considered in this study, nutrient management plans on crop land generates nutrient reduction credits at lowest cost following cover crop on the crop land, nutrient management plan on the pasture land, and prescribed grazing on the pasture land. Per unit cost of nutrient reduction from the agricultural sources also differs among the watersheds. Supply curves of TP and TN for each WQT scenario were generated based on per unit cost and total amount of TP and TN reductions from different BMPs in 14 watersheds.

The cost of nutrient reduction $(\$ / \mathrm{lb})$ from the agricultural sources significantly differs under the two baseline requirements and market types. For example, the average per unit cost of TP reduction from cover crops on the crop land was about $29 \%$ higher under the nutrient management plan baseline requirement compared to using existing BMPs as a baseline requirement for the agricultural non-point sources. Similarly, the average per unit cost of TP reduction from the cover crop in the combined nutrient market was $88 \%$ lower than the average per unit cost of TP reduction in the single nutrient market. 
Nutrient reduction requirements for WWTPs were based on the most likely effluent limitations for the WWTPs in the watershed, their current level of nutrient concentration $(\mathrm{mg} / \mathrm{l})$, daily amount of nutrient discharge (lb.), and facility's discharge flow (MGD) (Section 6.4). The costs of nutrient reduction vary among the WWTPs according to the discharge flow, effluent limitations, and market types. For instance, in a single nutrient market, the cost of TP reduction at $1.0 \mathrm{mg} / \mathrm{l}$ effluent limit ranged from $\$ 44 / \mathrm{lb}$. to $\$ 770 / \mathrm{lb}$. and the cost of $\mathrm{TN}$ reduction at $8.0 \mathrm{mg} / \mathrm{l}$ ranged from $\$ 13 / \mathrm{lb}$. to $\$ 1,264 / \mathrm{lb}$. (Table 6.16). These per unit costs of TP and TN reduction were substantially low in the combined nutrient market. For a combined nutrient market, the cost of TP reduction at $1.0 \mathrm{mg} / \mathrm{l}$ effluent limit ranged from $\$ 11 / \mathrm{lb}$. to $\$ 244 / \mathrm{lb}$. and the cost of TN reduction at $8.0 \mathrm{mg} / \mathrm{l}$ ranged from $\$ 11 / \mathrm{lb}$. to $\$ 1,073 / \mathrm{lb}$. (Table 6.17).

The comparisons of per unit costs of $\mathrm{TP}$ and $\mathrm{TN}$ reductions between agricultural nonpoint sources and WWTPs (Sections 6.4 and 6.5) indicate a large potential for nutrients credit trading in the watershed. The costs of TN and TP reductions for majority of WWTPs were considerably higher at all effluent limitations than the costs of TN and TP reductions from the agricultural sources in the watershed.

This study estimates the consumer surplus, producer surplus, and total economic benefits from the WQT program under 12 different WQT scenarios (Section 6.7). Equilibrium prices levels (supply=demand) were computed for TP credits in both single and combined nutrients market, and for TN credits in a combined market (Table 6.41). The equilibrium price of phosphorus in a single nutrient market ranged from $\$ 52$ to $\$ 239$ per lb. of TP while the combined market had a price range of between $\$ 11.7$ and $\$ 55$ per lb. under 12 WQT scenarios. For $\mathrm{TN}$ credit prices in a combined market, prices ranged from $\$ 11$ to $\$ 48$ per $\mathrm{lb}$. The 
equilibrium prices were high under the scenarios with 2:1 trading ratio and nutrient management plan baseline requirement for agricultural sources.

All four WQT market design factors (baseline requirement for agricultural sources, trading ratio between point and non-point sources, effluent limitations for WWTPs, and market type) had significant impacts on the potential consumer surplus, producer surplus, and net economic benefits that will likely be generated from the WQT market in the watershed. The total economic benefits decrease under the nutrient management plan baseline requirements and 2:1 trading ratio compared to the net economic benefits under existing BMPs baseline requirements and 1:1 trading ratio. For example, at $1.0 \mathrm{mg} / 1 \mathrm{TP}$ limitation for WWTPs and 1:1 trading ratio, the net economic benefit was $\$ 1,219,197$ in existing BMPs baseline requirement (scenario 1) and $\$ 708,088$ in nutrient management plant baseline requirement (scenario 7). Similarly, under the 2:1 trading ratio, the net economic benefit was $\$ 504,738$ in existing BMPs baseline requirement (scenario 4) and $-\$ 259,673$ in nutrient management plant baseline requirement (scenario 10). Similar results for net economic benefits were found at $0.5 \mathrm{mg} / 1$ and $0.1 \mathrm{mg} / \mathrm{TP}$ limitations for the WWTPs. Under every scenario, the existence of a market (either single or combined) generates higher economic benefits when compared to no market (upgrading WWTP only).

This study indicates that the choice of type market for WWTPs depends on the effluent limitation enforced by the regulatory authority in the watershed. A combined nutrients market would be economically more feasible at a stringent $\mathrm{TP}$ limitation $(0.1 \mathrm{mg} / \mathrm{l})$. In this WQT feasibility analysis, the combined market generates a substantial amount of net annual economic benefit at $0.1 \mathrm{mg} / 1 \mathrm{TP}$ standard for all WWTPs in the watershed. But at less stringent TP limitations (1.0 and $0.5 \mathrm{mg} / \mathrm{l})$, a single nutrient market for TP trading generates more economic benefits than a combined market. 
WQT in the Greenbrier River watershed has the potential to provide significant cost savings over treatment plant upgrading to meet various effluent limitations for the WWTPs. Many significant WWTPs in the Greenbrier River could experience cost savings compared to treatment plant upgrade costs by purchasing TP credits in either a single market for TP or a combined market for TP and TN credits. The single nutrient market is economically feasible for Union PSD and Marlinton under all 12 WQT scenarios. The Hillsboro and Alderson WWTP can generate more net annual economic benefit from a combined nutrients market than in a single nutrient market. Similarly, the Pence Spring PSD and White Sulfur Spring can generate more net annual economic benefit from a combined nutrients market than in a single nutrient market under the existing BMPs baseline requirement for agricultural sources. Thus, the choice of market type for each WWTP depends on the effluent limitation for WWTPs and baseline requirement for agricultural sources.

For the seven WWTPs along the Greenbrier River, treatment plant upgrades to meet a $0.5 \mathrm{mg} / \mathrm{l}$ effluent standard for TP was projected to cost about $\$ 2.5$ million annually. The percentage of cost savings from the participation in a single market in the watershed ranged from $1 \%$ to $48 \%$ under different baseline requirements and trading ratios. The cost savings from the participation in a combined nutrients market in the watershed was about $61 \%$ under the existing BMPs baseline requirement and 1:1 trading ratio. This cost saving was about $37 \%$ under the existing BMPs baseline requirement and 2:1 trading ratio. Average cost saving was negative under the nutrient management plan baseline requirement for the agricultural sources.

The cost saving analyses for the individual WWTP in 12 different WQT scenarios indicate that all WQT scenarios are not feasible for all WWTPs. Effluent limitations for WWTPs, trading ratios, and baseline requirements for agricultural sources limit some WWTP's 
participation in the WQT program. Some WWTPs, e.g. Ronceverte and Pence Spring PSD, can only reduce their costs of treatment plant upgrading by purchasing credits at the more stringent effluent limitations. Under 1:1 trading ratio and existing BMPs baseline requirement, the Ronceverte WWTP can achieve cost savings by credit purchases costs only at $0.5 \mathrm{mg} / \mathrm{l}$ and 0.1 mg/l. TP limits. A trading ratio 2:1 will be costly for some of the WWTPs in the watershed. For instance, under existing BMPs baseline requirement and TP trading in a single nutrient market at a $0.5 \mathrm{mg} / 1 \mathrm{TP}$ standard, Pence Spring PSD, Alderson, White Sulfur Springs, and Ronceverte would not participate in trading under a 2:1 ratio.

When the non-point baseline requirement is increased to nutrient management plan for every nutrient credit generator (WQT Scenarios 6 through 12), a single TP market only is consistently economically feasible for two WWTP (i.e. Union PSD and Marlinton). This requirement drastically increased per unit costs of nutrient credit generation from agricultural sources. Thus, results show that participation in the single TP market will not be economically advantageous for many WWTPs under nutrient management plan baseline requirement. Under this increased baseline requirement, a combined $\mathrm{TN}$ and $\mathrm{TP}$ market would be necessary to achieve credit demands and cost savings across the majority of WWTP in the Greenbrier River watershed. Thus, caution should be taken when imposing effluent limits and trading ratios for the WWTPs and baseline requirements for the agricultural sources to include many WWTPs and farmers in the WQT program.

The existing level of BMPs and the choice of baseline requirements for agricultural sources have significant impacts on the amount of nutrient credit supply, cost of nutrient credit generation, and farmer's participation in the WQT market. Gosh et al. (2011) compares amount of nutrient credit supply and cost of nutrient credit generation between two baseline requirements 
based on the simulated data. The results of this study were consistent with the result of Gosh et al. (2011) study. The choice of $100 \%$ nutrient management plan for the agricultural sources reduces the total amount of TN and TP credits supply in the future WQT market. The total amount of TN and TP credits were 17\% and 31\% lower under the 100\% nutrient management plan baseline compared to an existing BMPs baseline.

The cost of credit generation increases for ex-ante BMP implementers under the existing level of BMP baseline requirement. For example, under the existing BMPs baseline, average costs of TN and TP credit generation from the cover crop for ex-ante BMPs implementers were $\$ 53.62$ and $\$ 146.61$, respectively. Under similar baseline, average costs of TN and TP credit generation for ex-post BMPs implementers were $\$ 13.10$ and $\$ 36.90$, respectively. In contrast, the cost of credit generation decreases for ex-ante BMP implementers under the $100 \%$ nutrient management plan baseline requirement. Under the existing level of BMP baseline requirements, farmers who had already implemented BMPs on their all agricultural land cannot generate any nutrient credits and automatically eliminated from the WQT market. Therefore, baseline for agricultural sources should be chosen based on the amount of pollution reduction target, and level and type of BMPs implemented by the farmers in the watershed.

\subsection{POLICY IMPLICATIONS}

This study has some important policy implications for water quality management at the watershed level. First, many streams and rivers in the Greenbrier River watershed do not have nutrient pollution monitoring data. The water quality model used in this study can be used to generate the data and information about the pollution discharge at the sub-watershed level. This information can be used for variety of purposes in the watershed. Examples include in the 
development of TMDLs and nutrient reduction standards, selection of BMPs under cost-share program, and valuation of surface water resources in the watershed.

Second, point and nonpoint source pollution reduction costs estimates in this study can provide valuable information for the policy makers and water quality regulators in the watershed. Theoretically, policy makers and regulators can create cost-minimizing pollution trading markets without knowing the abatement costs of individual agents (Horan and Shortle 2011, Hanley et al. 1997). However, the policy makers and regulators can use these cost information to design a viable WQT market which can generate better economic and environmental outcomes in the watershed.

For example, WVDEP has proposed TP standards of $0.5 \mathrm{mg} / \mathrm{l}$ for the WWTPs in the Greenbrier River watershed. Three WWTPs in the watershed, Pence Spring PSD (in both 1:1 and 2:1 trading ratios), Alderson (in 2:1 trading ratios), and White Sulfur Spring (in 2:1 trading ratios) cannot achieve a WQT cost savings compared to treatment plant upgrades at $0.5 \mathrm{mg} / \mathrm{TP}$ limit under the existing BMPs baseline requirement for the nutrient credit generators. This 0.5 mg/l TP limit would not be feasible for majority of WWTPs when the non-point baseline requirement is increased to nutrient management plan for every nutrient credit generator (WQT Scenarios 6 through 12). If WVDEP assigns $0.5 \mathrm{mg} / \mathrm{l} \mathrm{TP}$ limit to the all WWTPs in the Greenbrier River with a NMP as a baseline, TP trading between WWTPs and agricultural sources would not be a viable alternative to treatment plant upgrades for many WWTPs. Thus, this cost information will be helpful in designing a WQT program that offers costs savings to all or at least a majority of the WWTPs in the watershed. This study indicates that all WWTPs can participate in a WQT program under the existing baseline requirement at all TP limitations and 
1:1 trading ratio. Nutrient management plan baseline requirement would be feasible for many WWTPs only at the $0.1 \mathrm{mg} / \mathrm{l} \mathrm{TP}$ limit and combined nutrients market.

Third, this study compares the feasibility of a single nutrient standard with combined nutrient standards for WWTPs in the Greenbrier River watershed. Results indicate that equilibrium credit prices for TP drop substantially with inclusion of nitrogen standards and a TN market. However, only for the strictest of standards $(0.1 \mathrm{mg} / \mathrm{l})$ is the net economic benefits greater under a combined market compared to a single market. Thus, a regulator can consider combined nutrient standards for WWTPs in the watershed when stringent standards need to be applied.

Lastly, when designing and implementing a WQT program in a Greenbrier River watershed, local and state level program designers and managers are encouraged to review this study and make final programmatic decision based upon results of this study. Choice of baseline requirements for agricultural sources will have a great impact in the feasibility of WQT in the watershed. The proposed baseline for agricultural non-point sources in West Virginia is that a nutrient management plan must be implemented before credits can be generated. The results of this study indicate that when the baseline requirement is set at a nutrient management plan for every credit generator, this will make WQT infeasible for the majority of WWTPs in the Greenbrier watershed. Thus, policy makers need to carefully consider the proposed baseline requirement for agricultural non-point sources before developing a WQT program in the Greenbrier River watershed.

\subsection{LIMITATIONS OF THE STUDY}

There are many limitations in this study. First, the water quality model which was developed in the MapShed water quality modeling program requires validation to accurately predict stream flow and nutrient concentration in streams and rivers. Stream flow data for 
Greenbrier River were available for more than 20 years to validate the predicted streamflow in the MapShed. But the nutrients monitoring data were not available for a majority of the streams and rivers in the watershed. As a result, the estimated nutrients concentrations in the streams and rivers were validated based on very limited monitoring data. This lack of monitoring data limits the calibration of model to get more accurate estimates. Despite this limitation, the model provides a best available estimate of the most likely current nutrient loadings in the watershed and nutrient reduction potential from implementation of BMPs in the agricultural lands.

Second, the costs of WWTPs upgrade were estimated based on the methods developed by the Nutrient Reduction Technology Cost Task Force, Chesapeake Bay Program in 2002 (CBP 2002). A model developed in the one location may not accurately estimate costs of treatment plant upgrades for another location. A survey of WWTP's compliance costs of nutrients reduction can provide better information for cost estimation.

Third, only three BMPs were used to estimate the potential supply of nutrient credits from the agricultural sources in the watershed. Farmers in the watershed have the potential for additional nutrient load reductions from the implementation of other BMPs on their agricultural lands. For example, implementation of conservation tillage, buffer strips, stream bank restoration, etc. on the agricultural lands can likely generate additional nutrient credits. Thus, total TN and TP credits supply in this study should be considered as conventional estimates and agricultural sources have additional potential for nutrients reduction.

Fourth, this study assumes that BMPs are implemented independent of each other. Therefore, each BMP was simulated in the MapShed to estimate the nutrient reduction credits from the agricultural source. In reality, farmers implement combinations of BMPs on their crop and pasture lands. The nutrients reduction efficiency could be higher in the combination of 
BMPs than in single BMP. The model used in this study cannot estimate nutrients reduction from the combination of BMPs in the agricultural lands.

Fifth, Greenbrier River watershed is in a Karst region that allows nutrients to rapidly leach into the ground and pollute surface waters. About $10 \%$ of the watershed is characterized as karst (WVDEP 2011). The water quality model used to estimate nutrient loadings in this study did not account for a Karst soil character of the watershed which can significantly affect the total stream flow and amount of nutrient transfer through the soil. In particular, the Karst soil can increase total amount of nutrient runoff from the agricultural and forest lands to the rivers and streams. The water quality model without considering Karst soil characters can estimate less nutrient discharge than actual discharge.

Sixth, this study did not consider the combination of treatment facility upgrading and purchasing of credits in a WQT market as an alternative for the WWTPs in the watershed. For example, a WWTP could upgrade its treatment plant to meet $1 \mathrm{mg} / \mathrm{l} \mathrm{TP}$ standard and then purchase remaining reduction requirement from the WQT market to meet $0.5 \mathrm{mg} / \mathrm{l} \mathrm{TP}$ standard. This combination of treatment plant upgrade and use of credits from the WQT market may be a more cost effective alternative for the WWTP more stringent effluent limitations.

Seventh, this study assumes all farmers and significant WWTPs will participate in the potential WQT program in the watershed. In reality, they might be reluctant to participate in the WQT program despite the potential benefits from the participation. There are a number of attitudes or values that cause farmers to be reluctant adopting conservation practices. A strong pride in private property, a history of tensions with industrial actors, or a desire to be recognized for land stewardship are few of the attitudes and values that can establish powerful norms of 
behavior discouraging trades (Mariola 2009, Breetz et al. 2005, ). This study did not quantify the effects of such variables in a WQT program.

Lastly, while this study evaluated the net economic benefits from both single and combined nutrient markets, no attempt was made to conduct a benefit-cost analysis of different nutrient standards for TP. Thus, while the existence of a WQT market is clearly superior to no market from an economic efficiency standpoint, whether or not the setting of TP water quality standard (which is the basis for creating a TP credit market) generates more benefits to society than costs is not addressed in this research.

\subsection{RECOMMENDATIONS FOR FUTURE RESEARCH}

This study focused on the analysis of pollutant and economic feasibility of WQT program in the Greenbrier River watershed. All cost estimates for nutrient reduction from agricultural non-point sources and WWTPs were based on secondary information. Use of primary data collected from the farmers and WWTP's managers will increase the validity of the cost estimates. A survey or case study type research can be conducted to collect primarily data for the cost of nutrient abatement from the point and non-point sources.

Despite the pollutant and economic feasibility of a WQT program in the watershed, many agricultural sources and WWTPs may not participate in the WQT market. The survey used for this study did not collect the information about the farmer's and WWTP's interest to participate in various WQT scenarios analyzed in this study. A choice experiment could be conducted to determine the factors or market attributes that can encourage or discourage point and nonpoint sources to participate in various WQT scenarios. This information would enrich the WQT feasibility analysis and help to design better WQT program in the watershed level.

This study does not consider the impact of cost-share program in the WQT program. In the Greenbrier River watershed, many farmers implement BMPs with NRCS cost share 
assistance. Both cost-share and WQT programs offer financial incentives to farmers to implement BMPs on their agricultural lands. There is a question about whether farmers who received cost-share funds for implementing BMPs and wish to participate in a water quality trading market should be allowed to sell all or only the portion of the nutrients reductions they generate at their own cost. There will be both economic and environmental consequences from the participation of such farmers in the WQT market. In-depth research about the effect of costshare program in the WQT program will also help to design a better WQT program considering cost-share program in the Greenbrier River watershed.

Research can be conducted to analyze the cost efficiency under the combination of treatment plant upgrade and purchase of credits in a WQT for the WWTPs in a watershed. As discussed in section 7.3, a combination of treatment plant upgrade and use of credits from a WQT market may be the most cost effective alternative for the WWTP more stringent effluent limitations. 


\section{REFERENCES}

Abdalla, C., T. Borisova, D. Parker and Blunk, K.S. 2007. "Water Quality Credit Trading and Agriculture: Recognizing the Challenges and Policy Issues Ahead”. Choices 22(2):117124.

Adler, R. W., J. C. Landman, and D. Cameron. 1993. "The Clean Water Act 20 Years Later". Natural Resources Defense Council. Washington, DC: Island Press.

Alexander, R. B., R. A. Smith, G. E. Schwarz, E. W. Boyer, J. V. Nolan and J. W. Brakebill. 2008. "Differences in Phosphorus and Nitrogen Delivery to the Gulf of Mexico from the Mississippi River Basin”. Environmental Science \& Technology 42 (3): 822-830.

Amborse, R. B. Jr., Wool, T. A., and T. O. Barnwell, Jr. 2009. "Development of Water Quality Modeling in the United States”. Environmental Engineering Research 14(4): 200-210.

Ambrose, R. B., Wool, T. A., Connolly, J. P., and Schanz, R. W. 1987. A Hydrodynamic and Water Quality Model-Model Theory, User's Manual and Programmers Guide. EPA/600/3-87/039, U.S. Environmental Protection Agency, Athens, GA.

Arnold, J. G. and N. Fohrer. 2005. "SWAT2000: "Current Capabilities and Research Opportunities in Applied Watershed Modeling”. Hydrological Processes 19: 563-572.

Bhumbla, D. K. 2010. Agricultural Practices and Nitrate Pollution of Water. West Virginia University Extension Services, Morgatown, WV.

Bicknell, B. R., J. C. Imhoff, J. L. Kittle Jr., Donigian, A. S. Jr. 1996. Hydrological Simulation Program - Fortran User's Manual For Release 11. Environmental Research Laboratory Office of Research and Development U.S. Environmental Protection Agency, Athens, Georgia.

Boisvert, R. N., G. L. Poe, and Y. Sado. 2007. "Selected Economic Aspects of Water Quality Trading: A Primer and Interpretive Literature Review". Available at: 
http://www.water.rutgers.edu/Projects/trading/Economic\%20Aspect_of_Water_Quality_ Trading final EPA.pdf

Boyer, D. G. 2005. "Water Quality Improvement Program Effectiveness for Carbonate Aquifers in Grazed Land Watersheds". Journal of the American Water Resources Association 41(2): 291-300.

Breetz, H. L. and K. Fisher-Vanden. 2007. "Does Cost-Share Replicate Water Quality Trading Projects? Implications for a Possible Partnership". Review of Agricultural Economics, 29 (2): 201-215.

Breetz, H. L., K. Fisher-Vanden, H. Jacobs, and C. Schary. 2005. "Trust and Communication: Mechanisms for Increasing Farmer's Participation in Water Quality Trading”. Land Economics, 81(2): 170-190.

Breetz, H. L., K. Fisher-Vanden, L. Garzon, H. Jacobs, K. Kroetz, and R. Terry. 2004. Water Quality Trading and Offset Initiatives in the U.S.: A Comprehensive Survey. Dartmouth College, New Hampshire.

Caplan, A. J. 2012. "Water Quality Trading in the Presence of Abatement-Cost Sharing". Contemporary Economic Policy DOI: 10.1111/j.1465-7287.2011.00308.x.

Carpenter, S. R., N. F. Caraco, D. L. Correll, R. W. Howarth, A. N. Sharpley, and V. H. Smith. 1998. "Nonpoint Pollution of Surface Waters with Phosphorus and Nitrogen". Ecological Applications 8 (3): 559-568.

CBP. 2002. Nutrient Reduction Technology Cost Estimations for Point Sources in the Chesapeake Bay Watershed. Chesapeake Bay Program, Annapolis, MD.

CENR. 2000. Integrated Assessment of Hypoxia in the Northern Gulf of Mexico. U.S. National Science and Technology Council (U.S.), Committee on Environment and Natural Resources. Washington D.C. 
Cestti, R., J. Srivastava, and S. Jung. 2003. Agriculture Non-Point Source Pollution Control: Good Management Practices-The Chesapeake Bay Experience. World Bank working paper no. 7, The World Bank, Washington, D.C.

Chaubey, I., L. Chiang, M. W. Gitau, and S. Mohamed. 2010. "Effectiveness of Best Management Practices in Improving Water Quality in a Pasture-Dominated Watershed”. Journal of Soil and Water Conservation 65 (6): 424-437.

Clean Water Act (CWA). 1972. Public Law 92-500-Oct.18.1972. Retrieved 15 March 2011 from http://www.glin.gov/download.action?fulltextId=68260\&documentId=67980\&glinID=6 $\underline{7980 .}$.

Copeland, C. 2010. Clean Water Act: A Summary of the Law. CRS Report to Congress, Congressional Research Service. Available at: http://www.nationalaglawcenter.org/assets/crs/RL30030.pdf

Copeland, C. 2011. Water Quality Issues in the 112th Congress: Oversight and Implementation. Congressional Research Service 7-5700, Congressional Research Service, Washington, D.C.

Cornes, R. and T. Sandler. 1996. The Theory of Externalities, Public Goods, and Club Goods. Cambridge, UK: Cambridge University Press.

Conservation Technology Information Center (CTIC). 2006. Getting Paid for Stewardship: An Agricultural Community Water Quality Trading Guide. Conservation Technology Information Center (CTIC), West Lafayette, IN.

Conservation Technology Information Center (CTIC). 2011. Wabash River Watershed Water Quality Trading Feasibility Study Final Report. Conservation Technology Information Center. West Lafayette, Indiana.

Deliman, P. N., W. J. Pack, and E. J. Nelson. 1999. Integration of the Hydrologic Simulation Program-FORTRAN (HSPF) Watershed Water Quality Model into the Watershed 
Modeling System (WMS). Technical Report W-99-2, Engineer Research and Development Center US Army Corps of Engineers.

Doering, O. C., F. Diaz-Hermelo, C. Howard, R. Heimlich, F. Hitzhusen, R. Kazmierczak, J. Lee, L. Libby, W. Milon, T. Prato, and M. Ribaudo. 1999. Evaluation of the Economic Costs and Benefits of Methods for Reducing Nutrient Loads to the Gulf of Mexico. Decision Analysis Series No. 20, NOAA Coastal Ocean Program, Silver Spring, Maryland.

Evans, B. M. and K. J. Corradini. 2012. MapShed Version 1.0 Users Guide. Penn State Institutes of Energy and the Environment, Pennsylvania State University, PA.

Evans, B. M., D.W. Lehning, K. J. Corradini, G. W. Petersen, E. Nizeyimana, J. M. Hamlett, P. D. Robillard, and R. L. Day. 2002. “A Comprehensive GIS-Based Modeling Approach for Predicting Nutrient Loads in Watershed". Journal of Spatial Hydrology, 2(2):1-18.

Faeth. P. 2000. Fertile Ground: Nutrient Trading Potential to Cost Effectively Improve Water Quality. World Resources Institute, Washington DC.

Feather, P. M. and J. Cooper. 1995. Voluntary Incentives for Reducing Agricultural Nonpoint Source Water Pollution. Agriculture Information Bulletin No. 716. U.S. Department of Agriculture, Economic Research Service, Washington, D.C.

Feng, F. K. W, Easter, and P. L. Brezonik. 2005. "Point-Nonpoint Source Water Quality Trading: A Case Study in the Minnesota River Basin”. Journal of the American Water Resources Association, 41(3): 645-658.

Freeman, A. M. 2003. The Measurement of Environmental and Resource Values: Theory and Method ( $2^{\text {nd }}$ edition). Resources for the Future, Washington, DC.

Ghosh, G. M. Ribaudo, and J. Shortle. 2011. "Baseline Requirements Can Hinder Trades in Water Quality Trading Programs: Evidence from the Conestoga Watershed". Journal of Environmental Management 92: 2076-2084. 
Goolsby D. A., Battaglin W. A., Lawrence G. B., Artz R. S., Aulenbach B. T., Hooper R. P., Keeney D. R. and Stensland G. J. 1999. Flux and Sources of Nutrients in the MississippiAtchafalaya River Basin; Topic 3. Report for the Integrated Assessment on Hypoxia in the Gulf of Mexico. NOAA Coastal Ocean Program Decision Analysis Series No. 17. NOAA, Silver Spring, MD.

Gould, G. A. 1990. "Agriculture, Nonpoint Source Pollution, and Federal Law". U.C. Davis Literature Review, 23: 461-491.

Haith, D. A. and L. L. Shoemaker. 1987. “Generalized Watershed Loading Functions for Stream Flow Nutrients". Water Resources Bulletin 23(3): 471-478.

Haith, D. A., N. Hollingshead, M. L. Bell, S. W. Kreszewski, and S. J. Morey. 2009. Estimation of Nutrient and Sediment Loads to Cayuga Lake Using the GWLF Watershed Model. Department of Biological and Environmental Engineering, Cornell University, Ithaca, NY.

Haith, D. R., R. Mandel, and R. S. Wu. 1992. GWLF: Generalized Watershed Loading Functions User's Manual, Version 2.0. Cornell University, Ithaca, NY.

Hanley, N., J. F. Shogren, and B. White. 1997. Environmental Economics in Theory and Practice. Oxford University Press, New York.

Harrington, W. 2003. Regulating Industrial Water Pollution in the United States. Discussion Paper 03-03. Resources for the Future, Washington, DC.

Heberling, M. T., J. H. Garcia, and H. W. Thurston. 2010. "Does Encouraging the Use of Wetlands in Water Quality Trading Programs Make Economic Sense?” Ecological Economics 69: 1988-1994.

Hemmelgarm, R. 2011. "Downstream”. Friends of the Lower Greenbrier River, Alderson, WV.

Hoag D. L. and J. S. Hughes-Popp. 1997. "Theory and Practice of Pollution Credit Trading in Water Quality Management”. Review of Agricultural Economics, 19(2): 252-262. 
Hoorman, J., T. Hone, T. Sudman, T. Dirksen, J. Iles, and K. R. Islam. 2008. “Agricultural Impacts on Lake and Stream Water Quality in Grand Lake St. Marys, Western Ohio". Water, Air, and Soil Pollution, 193(1-4): 309-322.

Horan, R. D. and J. S. Shortle. 2011. "Economic and Ecological Rules for Water Quality Trading". Journal of the American Water Resources Association, 47(1):59-69.

Horan, R. D. and J. S. Shortle. 2005. "When Two Wrongs Make a Right: Second-Best Point/Nonpoint Trading Ratios". American Journal of Agricultural Economics, 87 (2): 340-352.

Horan, R. D. and M. O. Ribaudo. 1999. "Policy Objectives and Economic Incentives for Controlling Agricultural Sources of Nonpoint Pollution". Journal of the American Water Resources Association, 35 (5): 1023-1035.

Horan, R. D., J. S. Shortle, and D. G. Abler. 2004. "The Coordination and Design of PointNonpoint Trading Programs and Agri-Environmental Policies". Agricultural and Resource Economics Review, 33 (1): 61-78.

Hung, M. and D. Shaw. 2005. "A Trading-Ratio System for Trading Water Pollution Discharge Permits". Journal of Environmental Economics and Management, 49: 83-102.

Im, S., K. Brannan, S. Mostaghimi, and J. Cho. 2003. "A Comparison of SWAT and HSPF Models for Simulating Hydrologic and Water Quality Responses from an Urbanizing Watershed". 2003 ASAE Annual International Meeting, 27- 30 July 2003 Las Vegas, Nevada, USA.

James, L. A. 2003. "Non-Point Source Pollution and the Clean Water Act: Policy Problems and Professional Prospects". Water Resources Update, 126:60-67.

Jarvie, M. and B. Solomon. 1998. "Point-Nonpoint Effluent Trading in Watersheds: A Review and Critique". Environmental Impact Assessment Review, 18: 135-157. 
Jenkins, G. P. and R. Lamech. 1992. Market-based Incentive Instruments for Pollution Control. The Netherlands: International Bureau of Fiscal Documentation.

Jayanayagam, S. 2005. "True Confessions of the Biological Nutrient Removal Process". Florida Water Resources Journal January 2005: 38-46.

Karigomba, W. 2009. A Spatial Optimization Approach to Watershed Water Quality Management: A Case of the Opequon Watershed. PhD Dissertation Submitted to the Davis College of Agriculture, Natural Resources, and Design, West Virginia University, WV.

Kaufman, G. B. 2011. Application of the Water Quality Analysis Simulation Program (WASP) to Evaluate Dissolved Nitrogen Concentrations in the Altamaha River Estuary, Georgia. A Thesis Submitted to the Department of Marine Sciences, The University of Georgia, Athens, Georgia.

Keplinger, K. 2003. "The Economics of Total Maximum Daily Loads". Natural Resource Journal, 43: 1057-1092.

Keudel, M. 2006. Water Quality Trading: Theoretical and Practical Approaches. IWP Discussion Paper No. 2006/1. Institute for Economic Policy, Cologne, Germany.

Kieser and Associates. 2004. Preliminary Economic Analysis of Water Quality Trading Opportunities in the Great Miami River Watershed, Ohio. Kieser \& Associates, Kalamazoo, Michigan.

King, D. M. and P. J. Kuch. 2003. "Will Nutrient Credit Trading Ever Work? An Assessment of Supply and Demand Problems and Intuitional Obstacles". Environmental Law and Review, 33: 10352-10368.

King, D.M. 2005. “Crunch Time for Water Quality Trading”. Choices, 20 (1): 71-76 
Kovacic, D. A., Twait, R. M., Wallace, M. P., and Bowling, J. M. 2006. "Use of Created Wetlands to Improve Water Quality in the Midwest-Lake Bloomington Case Study". Ecological Engineering, 28: 258-270.

Lee, K.Y., T. R. Fisher, T. E. Jordan, D. L. Correll, and D. E. Weller, 2000. "Modeling the Hydrochemistry of the Choptank River Basin Using GWLF and Arc/Info: 1. Model Calibration and Validation". Biogeochemistry, 49:143-173.

Lee, M. C. 2009. Assessing Environmental Equivalents for Water Quality Trading. Doctoral Dissertation Submitted to the Department of Biological and Agricultural Engineering, Kansas State University, Manhattan, Kansas.

Letson, D. 1992. "Point/Nonpoint Source Pollution Reduction Trading: An Interpretive Survey". Natural Resources Journal, 32: 219-232.

Malik, A., D. Letson, and S. Crutchfield. 1993. "Point/Nonpoint Source Trading of Pollution Abatement: Choosing the Right Trading Ratio". American Journal of Agricultural Economics, 75: 959-967.

Mariola, J. M. 2009. Are Markets the Solution to Water Pollution? A Sociological Investigation of Water Quality Trading. PhD Dissertation Submitted to the Graduate Program in Rural Sociology, Ohio State University.

Miller, K. 2010. Toward a Typology of Tradable Mechanisms for Environmental Services. Discussion Brief. Northstar Initiative, Institute on the Environment, University of Minnesota.

Mississippi River/Gulf of Mexico Watershed Nutrient Task Force. 2008. Draft Gulf Hypoxia 2008 Action Plan. U.S. Environmental Protection Agency, Office of Wetlands, Oceans and Watersheds. Washington, D.C.

Morgan, C. and Wolveton, A. 2005. Water Quality Trading in the United States. Working Paper No 05-07. U.S. Environmental Protection Agency, National Center for Environmental Economics, Washington DC. 
National Research Council (NRC). 2008. Mississippi River Water Quality and the Clean Water Act: Progress, Challenges, and Opportunities. Washington, D.C.: National Academies Press.

Nash, J. E. and J. V. Sutcliffe. 1970. "River Flow Forecasting Through Conceptual Model Part IA Discussion of Principles”. Journal of Hydrology, 10 (3): 282-290.

Natural Resource Analysis Center (NRAC). 2007. Watershed Characterization Modeling System for ArcGIS 9.2. Release 1.0. Natural Resource Analysis Center, West Virginia University, Morgantown, WV.

Neitsch, S. L., J. G. Arnold, J. R. Kiniry, J. R. Williams, and K. W. King. 2002. Soil and Water Assessment Tool Theoretical Documentation- Version 2000. TWRI Report, Texas Water Resource Institute, College Station, Texas.

Neitsch, S. L., J.G. Arnold, J.R. Kiniry, J.R. Williams. 2011. Soil and Water Assessment Tool, Theoretical Decomentation Version 2009. Texas Water Resources Institute Technical Report No. 406, Texas A\&M University, College Station, Texas.

Nguyen, N. P., Shortle, J. S., Reed, P. M. and Nguyen, T. T., 2010. “A Less Perfect World for Emissions Trading: The Case of Water Quality with Uncertainty and Transaction Costs". Selected Paper for Special Session on Market-based mechanisms and the price dynamics of emission permits, 4th World Congress of Environmental and Resource Economists, Montreal, Canada, June 28-July 2. 2010.

Natural Resources Conservation Service (NRCS). 2009. 2008 NRCS Farm Bill Conservation Programs. U.S. Department of Agriculture, Natural Resource Conservation Program, Washington, D.C.

Natural Resources Conservation Service (NRCS). 2012b. WV 2012 EQIP Payment Schedule. West Virginia Natural Resources Conservation Service, Morgantown, WV. 
Natural Resources Conservation Service (NRCS). 2012a. FY 2011 EQIP Total Acres Treated, Contracts, Dollars Obligated. U.S. Department of Agriculture, Natural Resource Conservation Program, Washington, D.C.

Environmental Working Group (EWG). 2012. Conservation Reserve Program in United States, 1995-2011.Available at: http://farm.ewg.org/progdetail.php?fips=00000\&progcode=total_cr

Organization for Economic Co-operation and Development (OECD). 2001. Domestic Transferable Permits for Environmental Management: Design and Implementation. Paris: OECD Publications Service.

Osterman, L. E., P. W. Swarzenski, and R. Z. Poore. 2006. Gulf of Mexico Dead Zone- the Last 150 Years: USGS Fact Sheet 2006-3005. Available at: pubs.usgs.gov/fs/2006/3005/.

Perman, R., Y. Ma, J. McGilvary, and M. Common. 2003. Natural Resource and Environmental Economics ( ${ }^{\text {rd }}$ edition). Pearson Education Limited, London, UK.

Peterson, J. M., J. A. Fox, J. C. Leatherman, and C. M. Smith. 2007. "Choice Experiments to Assess Farmers' Willingness-to-Participate in a Water Quality Trading Market”. Selected Paper Prepared for Presentation at the American Agricultural Economics Association Annual Meeting, Portland, Oregon, July 29-August 1, 2007.

Pharino, C. 2007. Sustainable Water Quality Management Policy, the Role of Trading: The U.S. Experience. The Netherlands: Springer.

Rabalais, N. N., R. E. Turner, and D. Scavia. 2002. Beyond Science into Policy: Gulf of Mexico Hypoxia and the Mississippi River. BioScience, 52 (2): 129-142.

Rabalais, N. N., R. E. Turner, Q. Dortch, D. Justic, V. J. Bierman, Jr. and W. J. Wiseman, Jr. 2002. "Review of Nutrient-enhanced Productivity in the Northern Gulf of Mexico: Past, Present and Future". Hydrobiologia, 475/476: 39-63. 
Rabalais, N.N., Turner R.E., Justic D., Dortch, Q.,Wiseman W.J., Sen Gupta B.K. 1996. "Nutrient Changes in the Mississippi River and System Responses on the Adjacent Continental Shelf'. Estuaries, 19 (2b): 286-407.

Rao, N. S., Z. M. Easton, E. M. Schneiderman, M. S. Zion, D. R. Lee, and T. S. Steenhuis. 2009. "Modeling Watershed-Scale Effectiveness of Agricultural Best Management Practices to Reduce Phosphorus Loading”. Journal of Environmental Management, 90: 1385-1395.

Ribaudo, M. O., and C. J. Nickerson. 2009. "Agriculture and Water Quality Trading: Exploring the Possibilities." Journal of Soil and Water Conservation, 64(1):1-7.

Ribaudo, M. O., and J. Gottlieb. 2011. "Point-Nonpoint Trading-Can It Works?" Journal of the American Water Resources Association, 47(1):5-14.

Ribaudo, M., G. Gosh, and J. Shortle. 2009. "Do Baseline Requirements Hinder Trades in Water Quality Trading Programs?" Selected Paper Prepared for Presentation at the Agricultural \& Applied Economics Association's 2009 AAEA \& ACCI Joint Annual Meeting, Milwaukee, WI, July 26-28, 2009.

Ruppert, T. K. 2004. "Water Quality Trading and Agricultural Nonpoint Source Pollution: An Analysis of the Effectiveness and Fairness of EPA's Policy on Water Quality Trading". Villanova Environmental Law Journal, 15 (1): 1-49.

Scavia, D., N. N. Rabalais, R. E. Turner, D. Justic, and W. J. Wiseman, Jr. 2003. "Predicting the Response of Gulf of Mexico Hypoxia to Variations in Mississippi River Nitrogen Load". Limnology \& Oceanography, 48: 951-956.

Schneiderman, E. M., D.C. Pierson, D. G. Lounsbury, and M. S. Zion. 2002. "Modeling the Hydrochemistry of the Cannonsville Watershed with Generalized Watershed Loading Functions (GWLF)". Journal of the American Water Resources Association, 38 (5): 1323-1347. 
Schwarz, G. E., Hoos, A. B., Alexander, R. B., and Smith, R. A. 2006. The SPARROW Surface Water-Quality Model-Theory, Applications and User Documentation. U.S. Geological Survey, Reston, Virginia.

Selman, M., S. Greenhalgh, E. Branosky, C. Jones, and J. Gulling. 2009. Water Quality Trading Programs: An International Overview. WRI Issue Brief No. 1. World Resource Institute, Washington, D.C.

Serre, C. 2008. Tradable Permit Schemes in Environmental Management: Evolution Patterns of an Expanding Policy Instrument. Berlin: Sounding Study.

Shabman, L. and K. Stephenson. 2007. "Achieving Nutrient Water Quality Goal: Market- Like Principles to Water Quality Management". Journal of the American Water Resources Association 43(4): 1076-1089.

Shortle, J. and R. Horan, and D. Abler. 1998. "Research Issues in Nonpoint Pollution Control". Environmental and Resource Economics, 11(3-4): 571-585.

Shortle, J. S. 1987. "Allocative Implications of Comparisons between the Marginal Costs of Point and Nonpoint Source Pollution Abatement”. Northeastern Journal of Agricultural and Resource Economics, 16 (1): 17-23

Shortle, J. S. and R. D. Horan. 2008. “The Economics of Water Quality Trading”. International Review of Environmental and Resource Economics 2(2):101-133.

Shortle, J. S., and D. G. Abler. 1997. "Nonpoint Pollution.” In H. Folmer and T. Tietenberg (eds.), The International Yearbook of Environmental and Resource Economics, 1997/98. Cheltenham, UK: Edward Elgar.

Shortle, J. S., R. D. Horan, and D. G. Abler. 1998. "Research Issues in Nonpoint Pollution Control". Environmental and Resource Economics, 11 (3-4): 571-585.

Shortle, J.S. and D. Abler. 2001. Environmental Policies for Agricultural Pollution Control. London, UK: CABI Publishing. 
Singh, V. P. and D. K. Frevert. 2006. Watershed Models. Florida: Taylor and Francis Group, LLC.

Smith, R. A., G. E. Schwarz, and R. B. Alexander. 1997. "Regional Interpretation of WaterQuality Monitoring Data”. Water Resources Research, 33(12): 2781-2798.

Smith, V.H. 2003. "Eutrophication of Freshwater and Coastal Marine Ecosystems a Global Problem”. Environmental Science and Pollution Research, 10 (2): 126-139.

Stavins, R. 1995. "Transactions Costs and Tradable Permits". Journal of Environmental Economics and Management, 29: 133-148.

Strager, M. P., J. J. Fletcher, J. M. Strager, C. B. Yuill, R. N. Eli, J. T. Petty, and S. J. Lamont. 2010. "Watershed Analysis with GIS: The Watershed Characterization and Modeling System Software Application”. Computers and Geosciences, 36: 970-976.

Summers, J. 2008. Assessment of Filamentous Algae in the Greenbrier River and other West Virginia Streams. West Virginia Department of Environmental Protection, Charleston, WV.

Tietenberg, T. H. 1990. "Economic Instruments for Environmental Regulation”. Oxford Review of Economic Policy, 6 (1): 17-33.

Tietenberg, T. T. 2007. "Tradable Permits in Principle and Practice”. In J. Freeman and C. D. Kolstad (eds), Moving to Markets in Environmental Regulation: Lessons from Twenty Years of Experience. New York: Oxford University Press.

Tietenberg, T. H. 2006. Emission Trading Principles and Practices $2^{\text {nd }}$ edition. Washington DC: Resources for the Future.

United States Department of Agriculture/Natural Resources Conservation Service (USDA/NRCS). 2003. Environmental Quality Incentives Program, Final Rule. Federal Register. 6832337-55. 
United States Environmental Protection Agency (USEPA). 1985. Guidelines for Deriving Numerical National Water Quality Criteria for the Protection of Aquatic Organisms and their Uses. PB85-227049. National Technical Information Service. Springfield, VA.

United States Environmental Protection Agency (USEPA). 1989. Nonpoint Sources: Agenda for the Future. Office of Water, Washington D.C.

United States Environmental Protection Agency (USEPA). 1996. Draft Framework for Watershed Based Training. EPA 800-R-96-001, Office of Water, Washington, D.C.

United States Environmental Protection Agency (USEPA). 1997. Clean Water Act and TMDLs. 97-831 ENR, Office of Water, Washington, D.C.

United States Environmental Protection Agency (USEPA). 1997. Compendium of Tools for Watershed Assessment and TMDL Development. Office of Water, Washington, D.C.

United States Environmental Protection Agency (USEPA). 1998. Better Assessment Science Integrating Point and Nonpoint Sources. EPA-823-B-98-006, Office of Water, Washington D.C.

United States Environmental Protection Agency (USEPA). 1999. Draft Guidance of Water Quality-Based Decisions: The TMDL Process (second edition). Office of Water, Washington D.C.

United States Environmental Protection Agency (USEPA). 2000a. Nutrient Criteria Technical Guidance Manual: Rivers and Streams. EPA-822-B-00-002, Office of Water, Washington, D.C.

United States Environmental Protection Agency (USEPA). 2000b. Nutrient Criteria Technical Guidance Manual. Lakes and Reservoirs. EPA-822-B-00-001. Office of Water, Washington, DC. 
United States Environmental Protection Agency (USEPA). 2001. Nutrient Criteria Technical Guidance Manual. Estuarine and Coastal Marine Waters. EPA-822-B-01-003, Office of Water, Washington, DC.

United States Environmental Protection Agency (USEPA). 2003a. Water Quality Trading Policy. Office of Water. Washington, D.C.

United States Environmental Protection Agency (USEPA). 2003b. Economic Analyses of Nutrient and Sediment Reduction Actions to Restore Chesapeake Bay Water Quality. Region III - Chesapeake Bay Program Office, Annapolis, MD.

United States Environmental Protection Agency (USEPA). 2004. Water Quality Trading Assessment Handbook: Can Water Quality Trading Advance your Watershed's Goal? EPA 841-B-04-001, Office of Water, Washington, DC.

United States Environmental Protection Agency (USEPA). Evaluation of the Role of Nitrogen and Phosphorus in Causing or Contributing to Hypoxia in the Northern Gulf. U.S. Environmental Protection Agency Region, Atlanta, Georgia

United States Environmental Protection Agency (USEPA). 2007a. Hypoxia in the Northern Gulf of Mexico: An Update by the EPA Science Advisory Board. Office of the Administrator, EPA Science Advisory Board. Washington DC.

United States Environmental Protection Agency (USEPA). 2007b. Water Quality Trading Toolkit for Permit Writers, EPA-833-R-07-004, Office of Water Management, Water Permit Division, Washington, D.C.

United States Environmental Protection Agency (USEPA). 2008. Clean Watersheds Needs Survey 2004 Report to Congress. Office of Water, Washington, DC. Available at: http://www.epa.gov/cwns/2004rtc/cwns2004rtc.pdf.

United States Environmental Protection Agency (USEPA). 2008. Handbook for Developing Watershed Plans to Restore and Protect Our Waters. EPA 841-B-08-002, Office of Water, Washington, D.C. 
United States Environmental Protection Agency (USEPA). 2008. Nutrient Criteria Technical Guidance Manual. Wetlands. EPA-822-B-08- 001, Office of Water, Washington, DC.

United States Environmental Protection Agency (USEPA). 2009. National Water Quality Inventory: Report to Congress, 2004 Reporting Cycle. EPA Report no. 841-R-08-001, Office of Water, Washington, D.C.

United States Environmental Protection Agency (USEPA). 2011. Moving Forward on Gulf Hypoxia, Annual Report 2011. Mississippi River Gulf of Mexico Watershed Nutrient Task Force, Office of Wetlands, Oceans, and Watersheds, Washington, D.C.

United States Environmental Protection Agency (USEPA). 2011. What are Water Quality Standards? Water Quality Criteria. Retrieved 16 March 2011 from http://water.epa.gov/scitech/swguidance/waterquality/standards/crit.cfm

United States Environmental Protection Agency (USEPA). 2012. Water Quality Analysis Simulation Program (WASP). Available at: http://www.epa.gov/athens/wwqtsc/html/wasp.html

United States Government Accountability Office (USGAO). 2002. Water Infrastructure: Information on Financing, Capital Planning, and Privatization. GAO-02-764, Washington, D.C. Available at: http://www.gao.gov/new.items/d02764.pdf.

United States Government Accountability Office (USGAO). 2008. Physical Infrastructure, Challenges and Investment Options for the Nation's Infrastructure. GAO-08-763T, Washington, D.C. Available at: http://www.gao.gov/new.items/d08763t.pdf.

Williams, D. R. 2002. "When Voluntary, Incentive-Based Controls Fail: Structuring a Regulatory Response to Agricultural Nonpoint Source Water Pollution". Journal of Law and Policy 9 (21): 21-121.

Woodward, R. T. and R. A. Kaiser. 2002. "Market Structures for U.S. Water Quality Trading". Review of Agricultural Economics, 24(2): 366-383. 
Woodward, R. T., R. A. Kaiser, and A. B. Wicks, 2002. "The Structure and Practice of Water Quality Trading Markets.” Journal of the American Water Resources Association, 38(4): 967-979.

Wool, T. A., R. B. Ambrose, J. L. Martin, and E. A. Comer. 2004. Water Quality Analysis Simulation Program, WASP version 6.0. Draft: User's Manual\|. USEPA, Region IV, Atlanta, GA.

Water Science and Technology Board (WSTB). 2009. Nutrient Control Actions for Improving Water Quality in the Mississippi River Basin and Northern Gulf of Mexico., National Research Council of the National Academies, National Academies Press, Washington, D.C.

West Virginia Department of Environmental Protection (WVDEP). 2006. West Virginia Integrated Water Quality Monitoring and Assessment Report 2006. Division of Water and Waste Management, Charleston, WV.

West Virginia Department of Environmental Protection (WVDEP). 2008. West Virginia Integrated Water Quality Monitoring and Assessment Report 2008. Division of Water and Waste Management, Charleston, WV.

West Virginia Department of Environmental Protection (WVDEP). 2010. West Virginia Integrated Water Quality Monitoring and Assessment Report 2010. Division of Water and Waste Management, Charleston, WV.

West Virginia Department of Environmental Protection (WVDEP). 2011. Greenbrier River State of the Watershed 2011. Division of Water and Waste Management, Charleston, WV.

West Virginia Department of Environmental Protection (WVDEP). 2012. Water Quality Standards. West Virginia Department of Environmental Protection. Available at http://www.dep.wv.gov/WWE/Programs/wqs/Pages/default.aspx 
West Virginia Geographical Information System Technical Center (WVGISTC). 2012. WV State GIS Data Clearinghouse. Department of Geology and Geography, West Virginia University, Morgantown, WV.

West Virginia Natural Resources Conservation Service (WVNRCS). 2012. FY2012 Environmental Quality Incentive Payment Schedule. Morgantown, West Virginia.

West Virginia Water Research Institute (WVWRI). 2008. DRAFT West Virginia Potomac River Basin Water Quality Nutrient Trading Program. West Virginia University, Morgantown, WV.

West Virginia Water Research Institute (WVWRI). 2008. DRAFT West Virginia Water Quality Nutrient Credit Trading Program Guidelines. West Virginia University, Morgantown, WV.

Yuan, L. L., D. A. Thomas, J. F. Paul, M. J. Paul, and M. A. Kenney. 2010. Using Stressorresponse Relationships to Derive Numeric Nutrient Criteria. Office of Water, U.S. Environmental Protection Agency, Washington, DC. 


\section{APPENDIX A: THE WCMS MODEL ESTIMATIONS}

Table A1: Estimated TN and TP discharge from agricultural sources

\begin{tabular}{ccccc}
\hline Sub-Watershed & $\begin{array}{c}\text { Nitrogen } \\
(\mathrm{Mg} / \mathrm{L})\end{array}$ & $\begin{array}{c}\text { Nitrogen-Load } \\
(\mathrm{Kg} / \mathrm{yr})\end{array}$ & $\begin{array}{c}\text { Phosphorus } \\
(\mathrm{Mg} / \mathrm{L})\end{array}$ & $\begin{array}{c}\text { Phosphorus- } \\
\text { Load (Kg/yr) }\end{array}$ \\
\hline Deer Creek-Greenbrier River & 3.41 & 520,469 & 0.24 & 10,849 \\
Knapp Creek & 3.10 & $11,301,00$ & 0.21 & 28,051 \\
Spring Creek & 2.94 & 484,333 & 0.20 & 18,989 \\
Sitlington Creek-Greenbrier & & & & \\
River & 3.41 & $2,025,040$ & 0.24 & 60,092 \\
Anthony Creek & 2.29 & 243,040 & 0.14 & 3,412 \\
Howard Creek & 2.78 & 154,528 & 0.18 & 1,943 \\
Second Creek & 3.40 & $2,922,060$ & 0.20 & 86,324 \\
Sinking Creek-Muddy Creek & 4.08 & $3,501,000$ & 0.24 & 114,335 \\
Wolf Creek-Greenbrier River & 4.50 & $3,869,670$ & 0.24 & 127,768 \\
\hline
\end{tabular}


APPENDIX B: COST OF WWTP UPGRADE FOR MEETING DIFFERENT EFFLUENT

LIMITS

Table B1: Estimated upgrade costs for TN reduction in a single nutrient market

\begin{tabular}{|c|c|c|c|c|c|}
\hline WWTP & $\begin{array}{c}\text { Flow } \\
(\mathrm{MGD})\end{array}$ & $\begin{array}{c}\mathrm{TCC} \\
(\$ 2011)\end{array}$ & $\begin{array}{l}\text { Annualized Cost for } \\
20 \text { years }(\mathrm{r}=2.1 \%)\end{array}$ & $\begin{array}{c}\text { O\&M } \\
(\$ 2011)\end{array}$ & $\begin{array}{c}\text { Total annual } \\
\text { Costs }\end{array}$ \\
\hline \multicolumn{6}{|l|}{ TN 8mg/l } \\
\hline Town of Alderson & 0.28 & $3,018,712$ & 184,141 & 60,874 & 245,015 \\
\hline $\begin{array}{c}\text { City of } \\
\text { Ronceverte }\end{array}$ & 0.97 & $4,678,113$ & 285,365 & 95,028 & 380,393 \\
\hline Union PSD & 0.08 & $4,763,929$ & 290,600 & 93,591 & 384,190 \\
\hline Pence Springs & 0.48 & $2,904,201$ & 177,156 & 57,763 & 234,919 \\
\hline $\begin{array}{l}\text { City of White } \\
\text { Sulfur Springs }\end{array}$ & 1.31 & $4,445,653$ & 271,185 & 85,799 & 356,984 \\
\hline Town of Hillsboro & 0.06 & $2,665,938$ & 162,622 & 53,423 & 216,045 \\
\hline $\begin{array}{c}\text { City of Marlinton } \\
\text { TN 5mg/l }\end{array}$ & 0.21 & $3,107,418$ & 189,553 & 62,408 & 251,961 \\
\hline Town of Alderson & 0.28 & $3,817,050$ & 232,840 & 78,051 & 310,892 \\
\hline $\begin{array}{c}\text { City of } \\
\text { Ronceverte }\end{array}$ & 0.97 & $6,955,334$ & 424,275 & 127,716 & 551,991 \\
\hline Union PSD & 0.08 & $7,090,223$ & 432,504 & 147,299 & 579,803 \\
\hline Pence Springs & 0.48 & $3,834,702$ & 233,917 & 78,343 & 312,259 \\
\hline $\begin{array}{l}\text { City of White } \\
\text { Sulfur Springs }\end{array}$ & 1.31 & $6,590,376$ & 402,013 & 122,604 & 524,617 \\
\hline Town of Hillsboro & 0.06 & $2,977,424$ & 181,623 & 60,693 & 242,316 \\
\hline $\begin{array}{c}\text { City of Marlinton } \\
\text { TN 3mg/l }\end{array}$ & 0.21 & $4,028,699$ & 245,751 & 70,949 & 316,699 \\
\hline Town of Alderson & 0.28 & $4,753,617$ & 289,971 & 122,625 & 412,595 \\
\hline $\begin{array}{c}\text { City of } \\
\text { Ronceverte }\end{array}$ & 0.97 & $10,396,446$ & 634,183 & 196,853 & 831,036 \\
\hline Union PSD & 0.08 & $10,641,492$ & 649,131 & 260,721 & 909,852 \\
\hline Pence Springs & 0.48 & $4,916,365$ & 299,898 & 130,693 & 430,592 \\
\hline $\begin{array}{l}\text { City of White } \\
\text { Sulfur Springs }\end{array}$ & 1.31 & $9,734,064$ & 593,778 & 200,813 & 794,591 \\
\hline Town of Hillsboro & 0.06 & $3,379,494$ & 206,149 & 84,306 & 290,455 \\
\hline City of Marlinton & 0.21 & $5,100,239$ & 311,115 & 92,589 & 403,703 \\
\hline
\end{tabular}


Table B2: Estimated upgrade costs for TP reduction in a single nutrient market

\begin{tabular}{|c|c|c|c|c|c|}
\hline $\begin{array}{l}\text { WWTP/Nutrient } \\
\text { limits }\end{array}$ & $\begin{array}{l}\text { Flow } \\
\text { (MGD) }\end{array}$ & $\begin{array}{c}\text { TCC } \\
(\$ 2011)\end{array}$ & $\begin{array}{l}\text { Annualized Cost for } \\
20 \text { years }(\mathrm{r}=2.1 \%)\end{array}$ & $\begin{array}{c}\text { O\&M } \\
(\$ 2011)\end{array}$ & $\begin{array}{l}\text { Total annual } \\
\text { Costs }\end{array}$ \\
\hline \multicolumn{6}{|l|}{ TP 1mg/l } \\
\hline $\begin{array}{c}\text { Town of Alderson } \\
\text { City of }\end{array}$ & 0.28 & $3,162,087$ & 192,887 & 9,174 & 202,061 \\
\hline Ronceverte & 0.97 & $4,900,809$ & 298,949 & 23,909 & 322,859 \\
\hline Union PSD & 0.08 & $5,019,414$ & 306,184 & 68,522 & 374,706 \\
\hline $\begin{array}{l}\text { Pence Springs } \\
\text { City of White }\end{array}$ & 0.48 & $2,985,211$ & 182,098 & 11,955 & 194,053 \\
\hline $\begin{array}{l}\text { Sulfur Springs } \\
\text { Town of }\end{array}$ & 1.31 & $4,670,857$ & 284,922 & 31,777 & 316,700 \\
\hline Hillsboro & 0.06 & $2,761,285$ & 168,438 & 4,860 & 173,299 \\
\hline $\begin{array}{l}\text { City of Marlinton } \\
\text { TP } 0.5 \mathrm{mg} / \mathbf{l}\end{array}$ & 0.21 & $3,286,813$ & 200,496 & 13,842 & 214,337 \\
\hline Town of Alderson & 0.28 & $3,960,425$ & 241,586 & 11,921 & 253,507 \\
\hline $\begin{array}{c}\text { City of } \\
\text { Ronceverte }\end{array}$ & 0.97 & $7,178,031$ & 437,860 & 32,386 & 470,246 \\
\hline Union PSD & 0.08 & $7,345,709$ & 448,088 & 85,177 & 533,265 \\
\hline Pence Springs & 0.48 & $3,915,712$ & 238,858 & 15,262 & 254,120 \\
\hline $\begin{array}{l}\text { City of White } \\
\text { Sulfur Springs }\end{array}$ & 1.31 & $6,815,579$ & 415,750 & 40,690 & 456,441 \\
\hline $\begin{array}{l}\text { Town of } \\
\text { Hillsboro }\end{array}$ & 0.06 & $3,072,772$ & 187,439 & 5,177 & 192,616 \\
\hline $\begin{array}{l}\text { City of Marlinton } \\
\text { TP } 0.1 \mathrm{mg} / \mathbf{l}\end{array}$ & 0.21 & $4,208,093$ & 256,694 & 15,365 & 272,059 \\
\hline Town of Alderson & 0.28 & $6,009,351$ & 366,570 & 144,097 & 510,667 \\
\hline $\begin{array}{c}\text { City of } \\
\text { Ronceverte }\end{array}$ & 0.97 & $13,512,213$ & 824,245 & 289,704 & $1,113,949$ \\
\hline Union PSD & 0.08 & $15,416,541$ & 940,409 & 523,538 & $1,463,947$ \\
\hline Pence Springs & 0.48 & $5,640,841$ & 344,091 & 200,587 & 544,678 \\
\hline $\begin{array}{l}\text { City of White } \\
\text { Sulfur Springs }\end{array}$ & 1.31 & $12,986,572$ & 792,181 & 307,302 & $1,099,483$ \\
\hline $\begin{array}{l}\text { Town of } \\
\text { Hillsboro }\end{array}$ & 0.06 & $3,990,421$ & 243,416 & 37,140 & 280,555 \\
\hline City of Marlinton & 0.21 & $6,687,182$ & 407,918 & 74,454 & 482,372 \\
\hline
\end{tabular}


Table B3: Estimated upgrade costs for TN reduction in a combined nutrient market

\begin{tabular}{|c|c|c|c|c|c|}
\hline $\begin{array}{l}\text { WWTP/Nutrient } \\
\text { limits }\end{array}$ & $\begin{array}{l}\text { Flow } \\
\text { (MGD) }\end{array}$ & $\begin{array}{c}\text { TCC } \\
(\$ 2011)\end{array}$ & $\begin{array}{l}\text { Annualized Cost for } \\
20 \text { years }(\mathrm{r}=2.1 \%)\end{array}$ & $\begin{array}{c}\text { O\&M } \\
(\$ 2011)\end{array}$ & $\begin{array}{l}\text { Total annual } \\
\text { Costs }\end{array}$ \\
\hline TN 8mg/l & & & & & \\
\hline $\begin{array}{l}\text { Town of Alderson } \\
\text { City of }\end{array}$ & 0.28 & $2,535,718$ & 154,679 & 60,874 & 215,552 \\
\hline Ronceverte & 0.97 & $4,023,177$ & 245,414 & 95,028 & 340,442 \\
\hline Union PSD & 0.08 & $4,192,257$ & 255,728 & 93,591 & 349,318 \\
\hline Pence Springs & 0.48 & $2,323,361$ & 141,725 & 57,763 & 199,488 \\
\hline Sulfur Springs & 1.31 & $3,423,153$ & 208,812 & 85,799 & 294,611 \\
\hline Town of Hillsboro & 0.06 & $2,319,366$ & 141,481 & 53,423 & 194,904 \\
\hline $\begin{array}{l}\text { City of Marlinton } \\
\text { TN 5mg/l }\end{array}$ & 0.21 & $2,703,454$ & 164,911 & 62,408 & 227,319 \\
\hline Town of Alderson & 0.28 & $3,206,322$ & 195,586 & 78,051 & 273,637 \\
\hline $\begin{array}{c}\text { City of } \\
\text { Ronceverte }\end{array}$ & 0.97 & $5,981,588$ & 364,877 & 127,716 & 492,593 \\
\hline Union PSD & 0.08 & $6,239,396$ & 380,603 & 147,299 & 527,902 \\
\hline Pence Springs & 0.48 & $3,067,762$ & 187,133 & 78,343 & 265,476 \\
\hline $\begin{array}{l}\text { City of White } \\
\text { Sulfur Springs }\end{array}$ & 1.31 & $5,074,590$ & 309,550 & 122,604 & 432,154 \\
\hline Town of Hillsboro & 0.06 & $2,590,359$ & 158,012 & 60,693 & 218,705 \\
\hline $\begin{array}{l}\text { City of Marlinton } \\
\text { TN 3mg/l }\end{array}$ & 0.21 & $3,504,968$ & 213,803 & 70,949 & 284,752 \\
\hline Town of Alderson & 0.28 & $3,993,038$ & 243,575 & 122,625 & 366,200 \\
\hline $\begin{array}{c}\text { City of } \\
\text { Ronceverte }\end{array}$ & 0.97 & $8,940,944$ & 545,398 & 196,853 & 742,251 \\
\hline Union PSD & 0.08 & $9,364,513$ & 571,235 & 260,721 & 831,956 \\
\hline Pence Springs & 0.48 & $3,933,092$ & 239,919 & 130,693 & 370,612 \\
\hline $\begin{array}{l}\text { City of White } \\
\text { Sulfur Springs }\end{array}$ & 1.31 & $7,495,230$ & 457,209 & 200,813 & 658,022 \\
\hline Town of Hillsboro & 0.06 & $2,940,160$ & 179,350 & 84,306 & 263,656 \\
\hline City of Marlinton & 0.21 & $4,437,208$ & 270,670 & 92,589 & 363,258 \\
\hline
\end{tabular}


Table B4: Estimated upgrade costs for TP reduction in a combined nutrient market

\begin{tabular}{|c|c|c|c|c|c|}
\hline $\begin{array}{l}\text { WWTP/Nutrient } \\
\text { limits }\end{array}$ & $\begin{array}{c}\text { Flow } \\
\text { (MGD) }\end{array}$ & $\begin{array}{c}\text { TCC } \\
(\$ 2011)\end{array}$ & $\begin{array}{l}\text { Annualized Cost for } \\
20 \text { years }(\mathrm{r}=2.1 \%)\end{array}$ & $\begin{array}{c}\text { O\&M } \\
(\$ 2011) \\
\end{array}$ & $\begin{array}{c}\text { Total annual } \\
\text { Costs } \\
\end{array}$ \\
\hline \multicolumn{6}{|l|}{ TP $1 \mathrm{mg} / \mathrm{l}$} \\
\hline $\begin{array}{c}\text { Town of Alderson } \\
\text { City of }\end{array}$ & 0.28 & 26,369 & 38,208 & 9,174 & 47,382 \\
\hline Ronceverte & 0.97 & 877,632 & 53,536 & 23,909 & 77,445 \\
\hline Union PSD & 0.08 & 27,157 & 50,457 & 68,522 & 118,978 \\
\hline Pence Springs & 0.48 & 61,850 & 40,373 & 11,955 & 52,328 \\
\hline City of White & & & & & \\
\hline Sulfur Springs & 1.31 & $1,247,703$ & 76,110 & 31,777 & 107,887 \\
\hline Town of Hillsboro & 0.06 & 41,919 & 26,957 & 4,860 & 31,817 \\
\hline $\begin{array}{l}\text { City of Marlinton } \\
\text { TP } 0.5 \text { mg/l }\end{array}$ & 0.21 & 83,359 & 35,585 & 13,842 & 49,427 \\
\hline Town of Alderson & 0.28 & 754,103 & 46,000 & 11,921 & 57,921 \\
\hline $\begin{array}{c}\text { City of } \\
\text { Ronceverte }\end{array}$ & 0.97 & $1,196,443$ & 72,983 & 32,386 & 105,369 \\
\hline Union PSD & 0.08 & $1,106,312$ & 67,485 & 85,177 & 152,662 \\
\hline Pence Springs & 0.48 & 847,950 & 51,725 & 15,262 & 66,987 \\
\hline $\begin{array}{l}\text { City of White } \\
\text { Sulfur Springs }\end{array}$ & 1.31 & $1,740,990$ & 106,200 & 40,690 & 146,891 \\
\hline Town of Hillsboro & 0.06 & 482,413 & 29,427 & 5,177 & 34,604 \\
\hline $\begin{array}{l}\text { City of Marlinton } \\
\text { TP } 0.1 \text { mg/l }\end{array}$ & 0.21 & 703,125 & 42,891 & 15,365 & 58,256 \\
\hline Town of Alderson & 0.28 & $2,016,313$ & 122,995 & 144,097 & 267,092 \\
\hline $\begin{array}{c}\text { City of } \\
\text { Ronceverte }\end{array}$ & 0.97 & $4,571,269$ & 278,847 & 289,704 & 568,551 \\
\hline Union PSD & 0.08 & $6,052,029$ & 369,174 & 523,538 & 892,712 \\
\hline Pence Springs & 0.48 & $1,707,749$ & 104,173 & 200,587 & 304,760 \\
\hline $\begin{array}{l}\text { City of White } \\
\text { Sulfur Springs }\end{array}$ & 1.31 & $5,491,343$ & 334,972 & 307,302 & 642,274 \\
\hline Town of Hillsboro & 0.06 & $1,050,261$ & 64,066 & 37,140 & 101,206 \\
\hline City of Marlinton & 0.21 & $2,249,973$ & 137,248 & 74,454 & 211,702 \\
\hline
\end{tabular}




\section{APPENDIX C: POTENTIAL DEMAND AND SUPPLY UNDER 12 WQT SCENAROS AND TWO MARKET TYPES}

Scenario 1: Trading Ratio (1:1), WWTP's Effluent Limit (8.0 $\mathrm{mg} / \mathrm{l} \mathrm{TN}, 1.0 \mathrm{mg} / \mathrm{l} \mathrm{TP})$, and baseline requirement (Existing Level of BMPs)

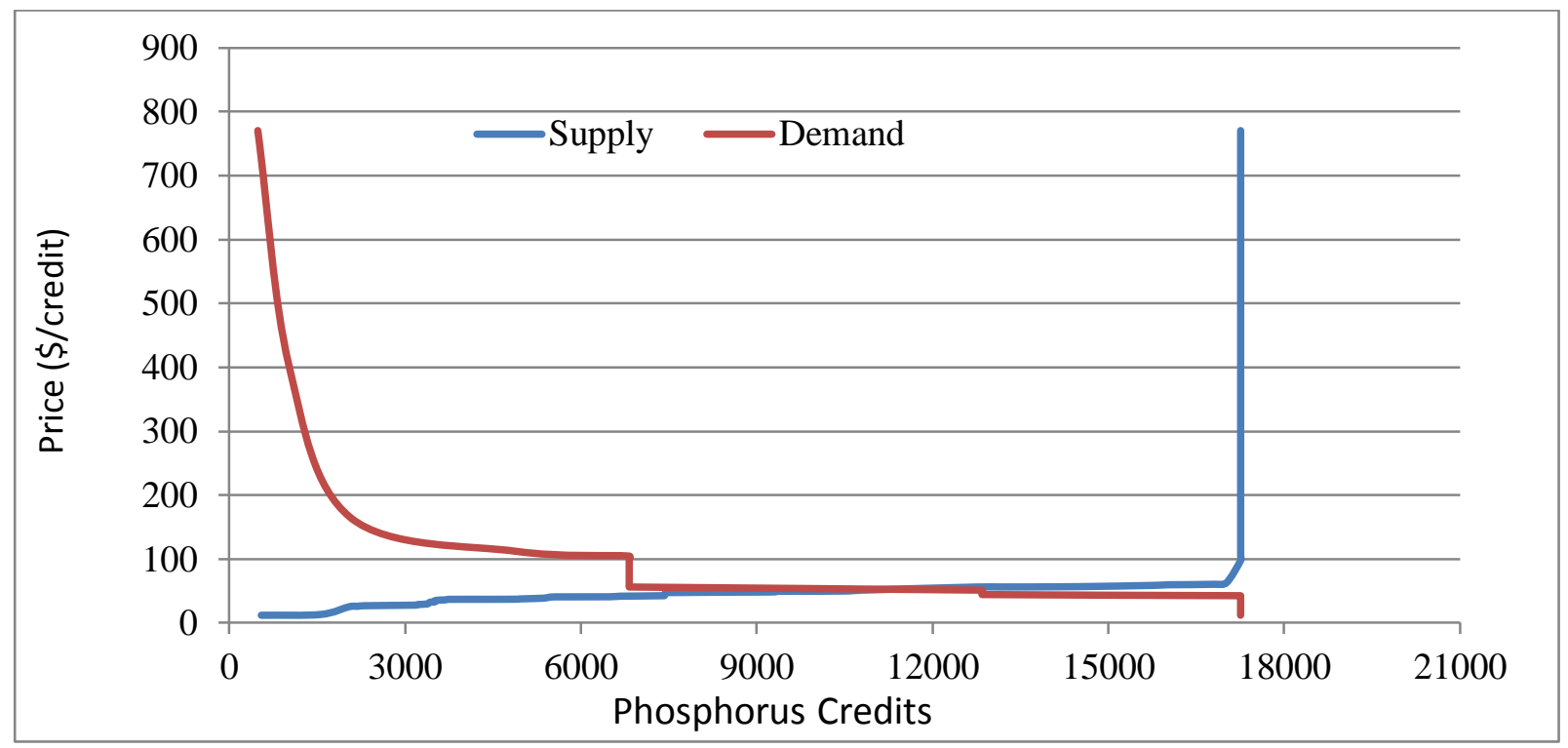

Figure C1: Potential Demand and Supply of TP Credits in a Single Nutrient Market in Scenario 1

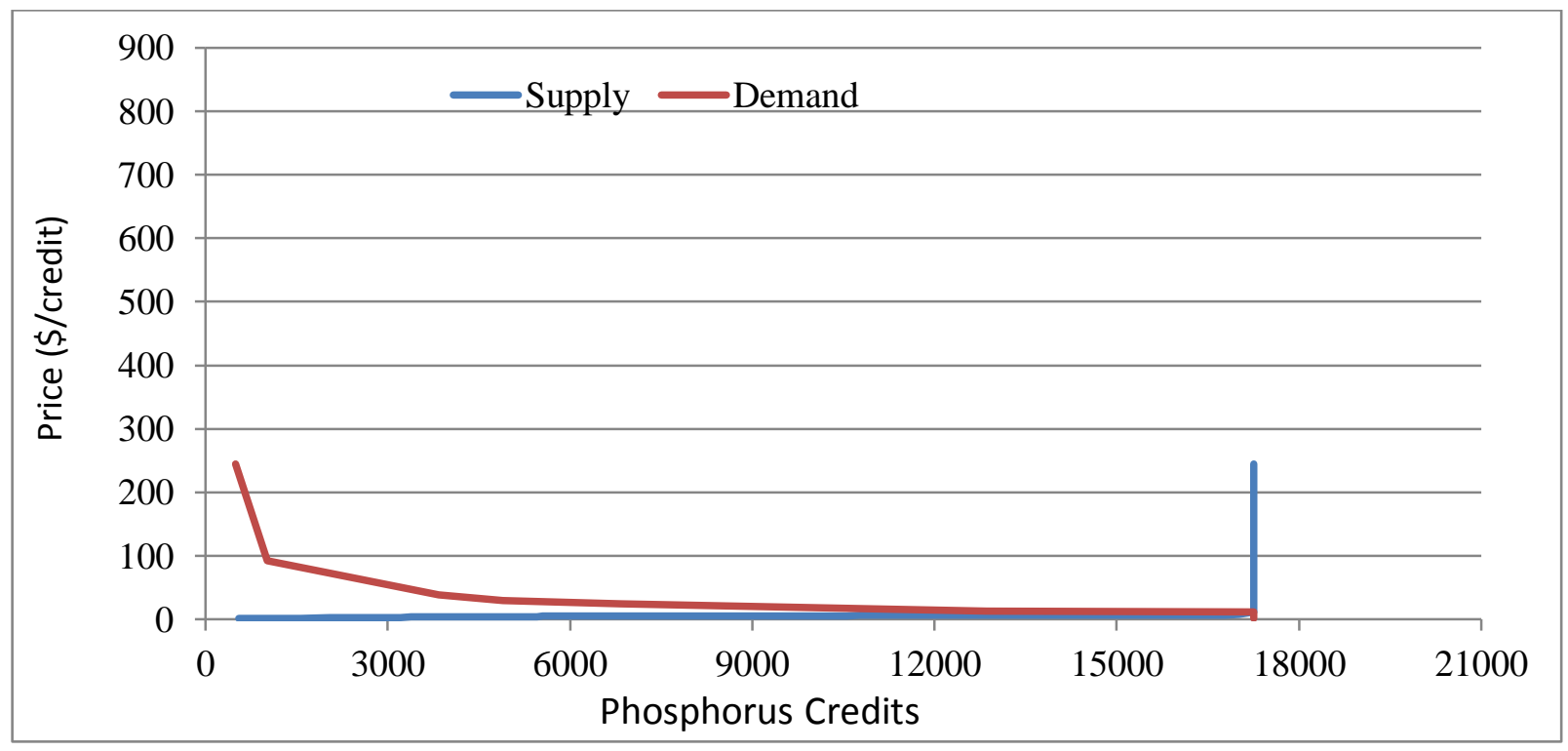

Figure C2: Potential Demand and Supply of TP Credits in a Combined Nutrient Market in Scenario 1 


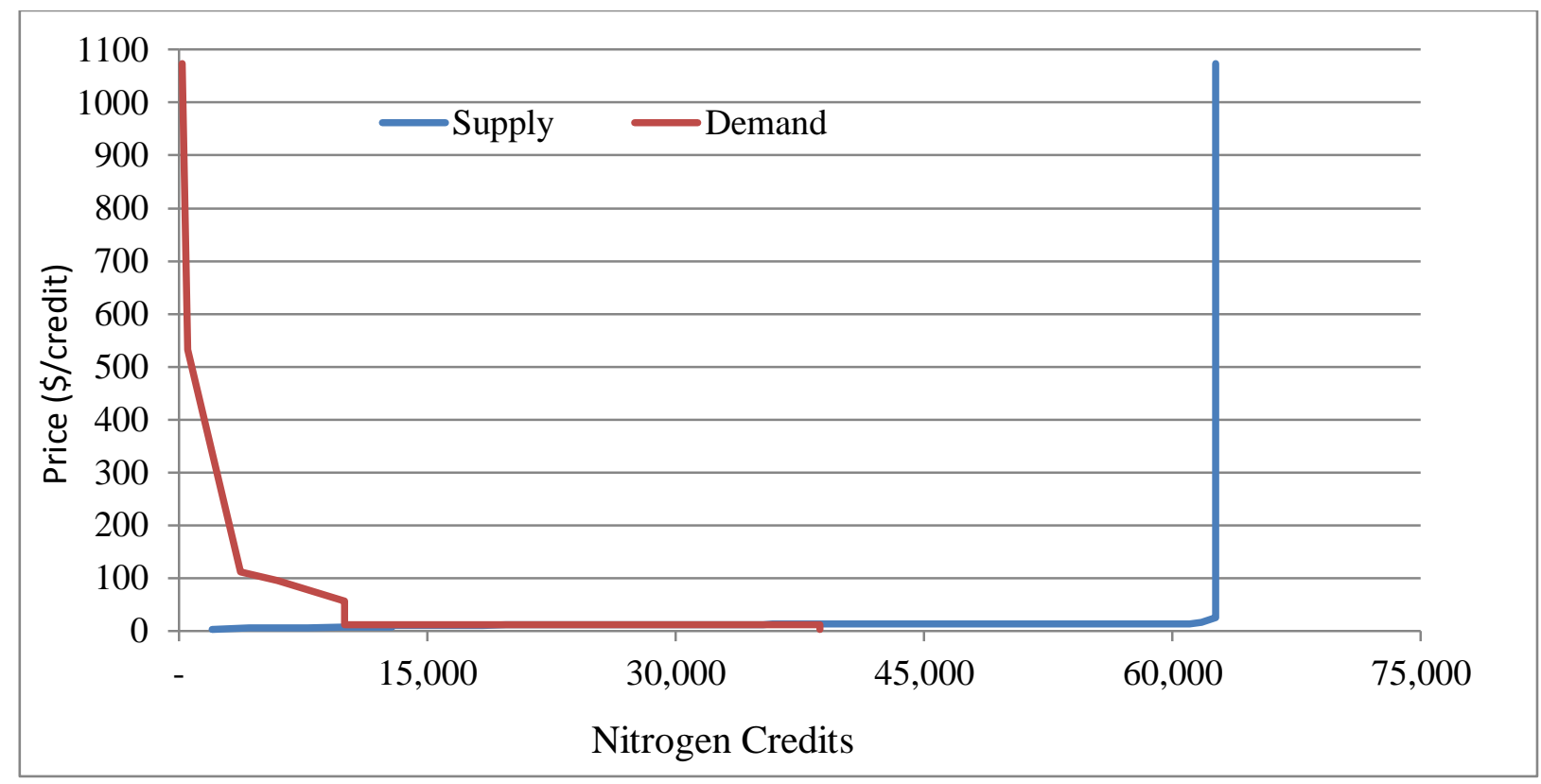

Figure C3: Potential Demand and Supply of TN Credits in a Combined Nutrient Market in Scenario 1

Scenario 2: Trading Ratio (1:1), WWTP's Effluent Limit (5.0 mg/l TN, $0.5 \mathrm{mg} / \mathrm{l} \mathrm{TP})$, and baseline requirement (Existing Level of BMPs)

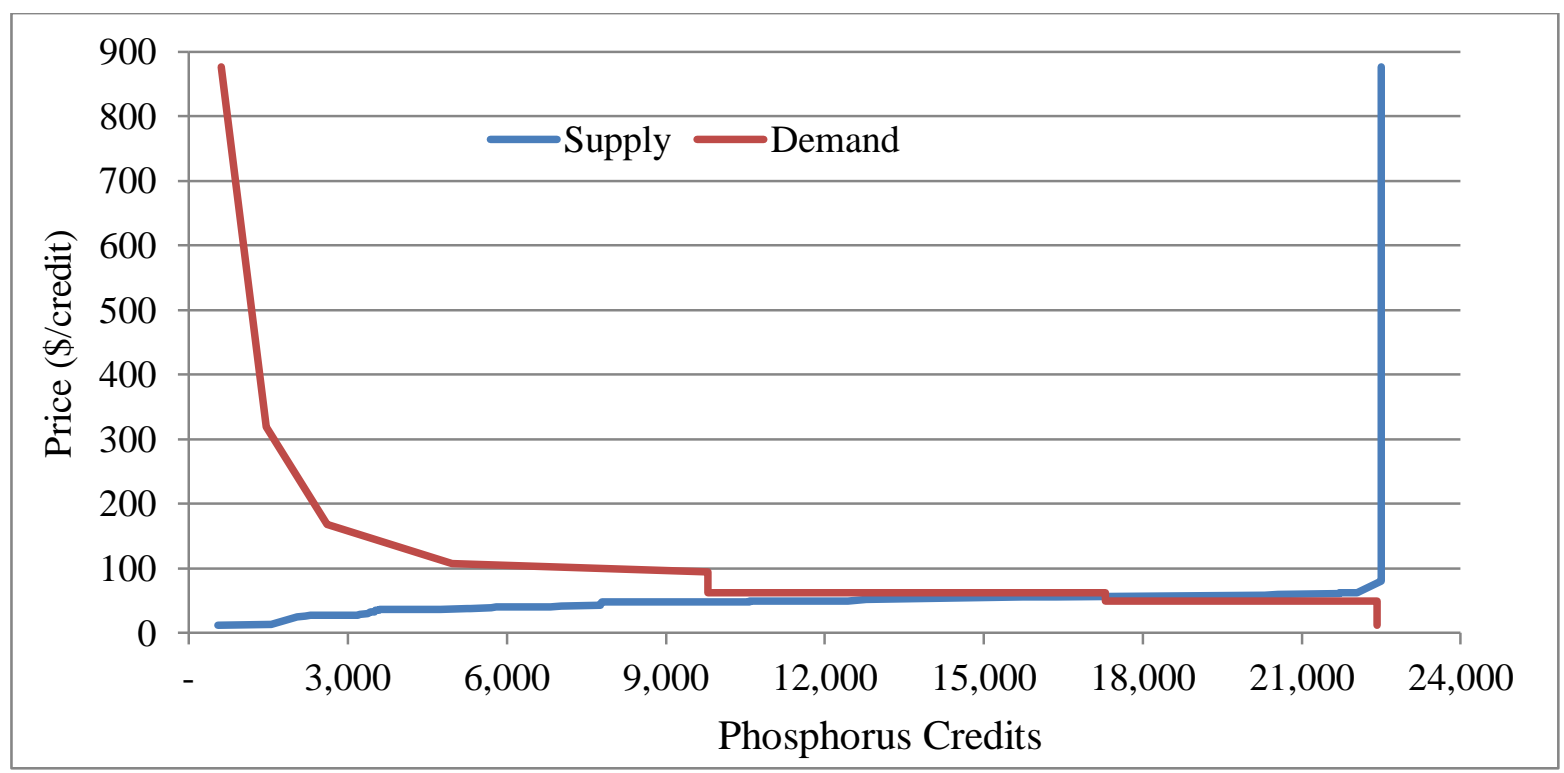

Figure C4: Potential Demand and Supply of TP Credits in a Single Nutrient Market in Scenario 2 


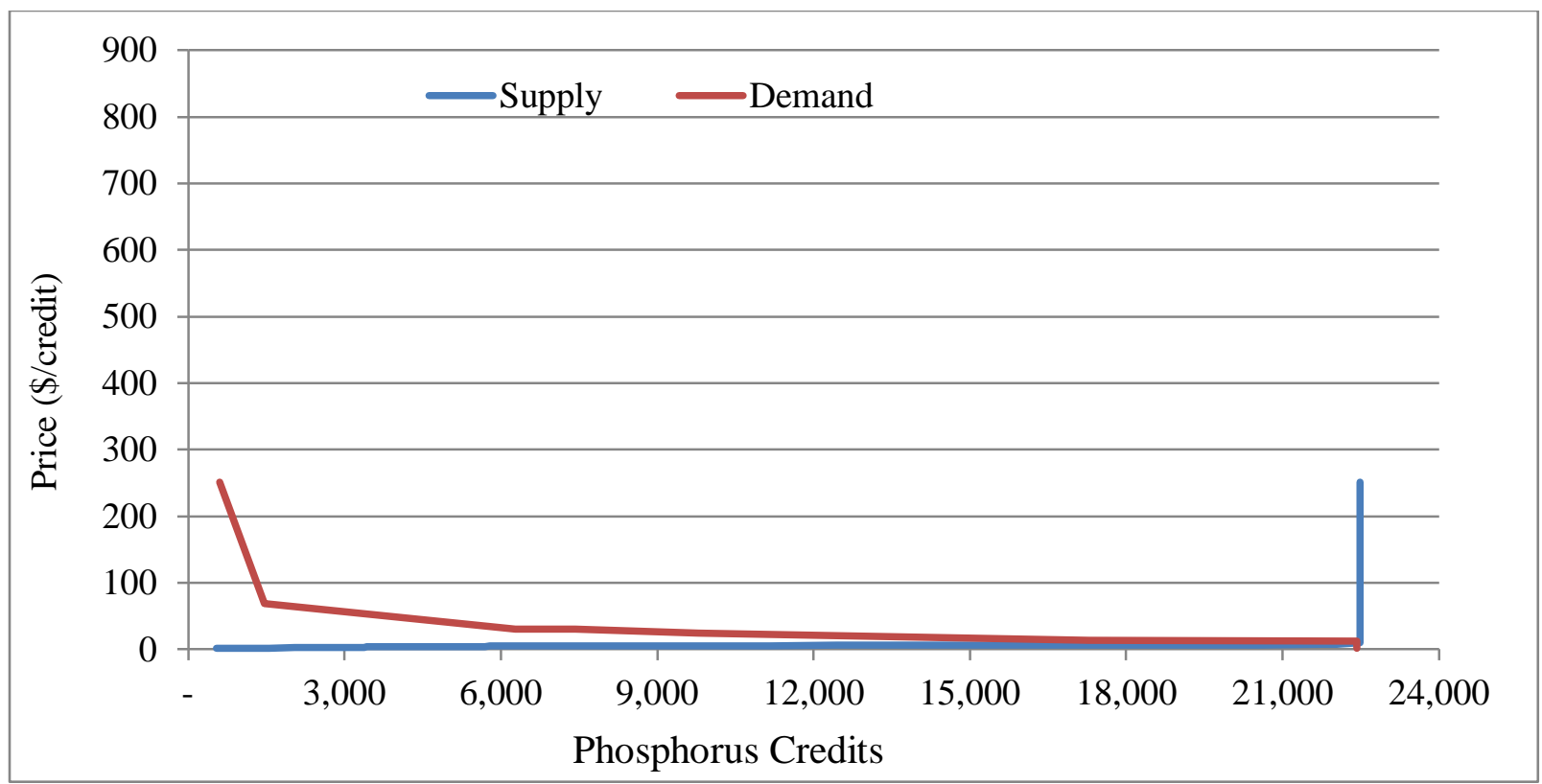

Figure C5: Potential Demand and Supply of TP Credits in a Combined Nutrient Market in Scenario 2

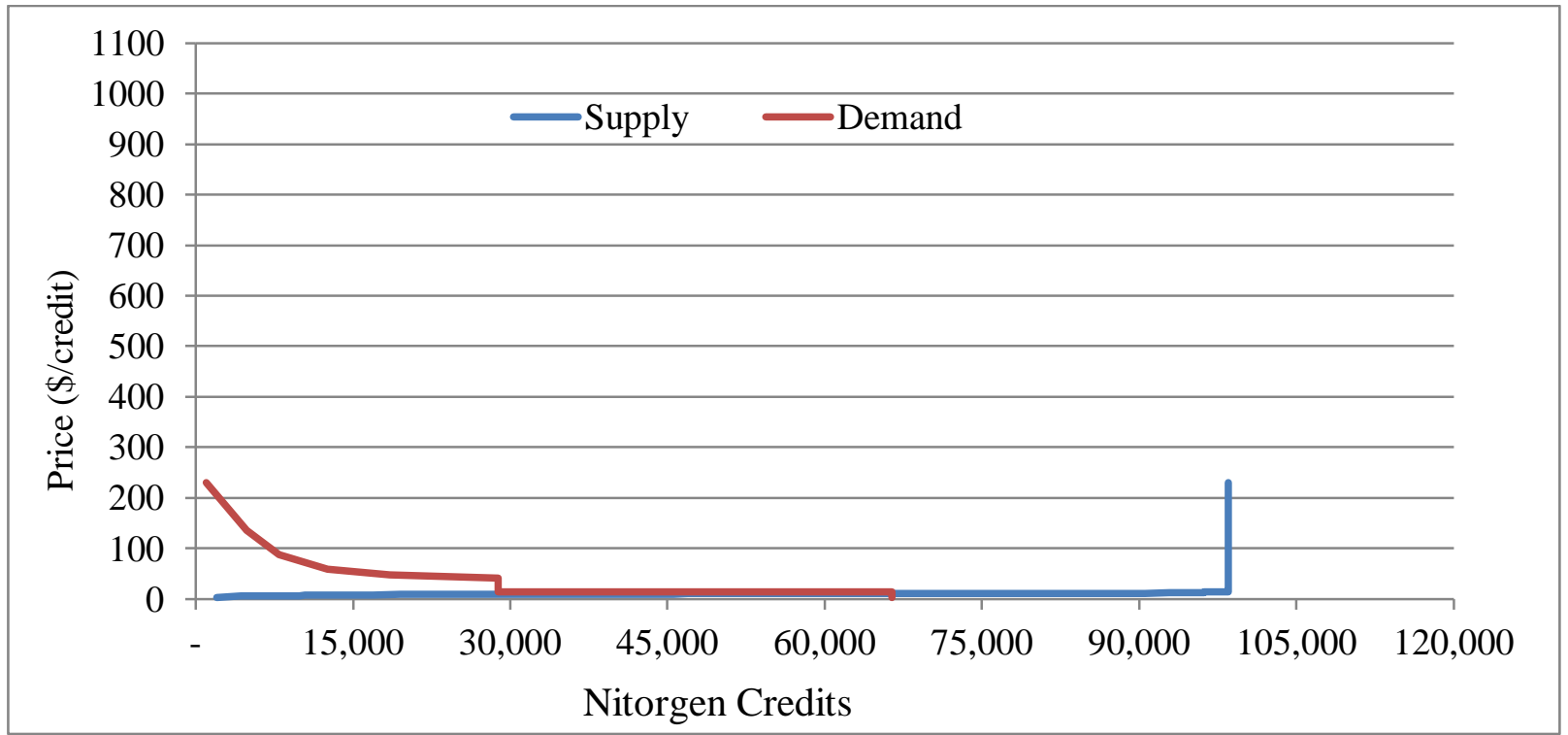

Figure C6: Potential Demand and Supply of TN Credits in a Combined Nutrient Market in Scenario 2 
Scenario 3: Trading Ratio (1:1), WWTP's Effluent Limit (3.0 mg/l TN, $0.1 \mathrm{mg} / \mathrm{l} \mathrm{TP}$ ), and baseline requirement (Existing Level of BMPs)

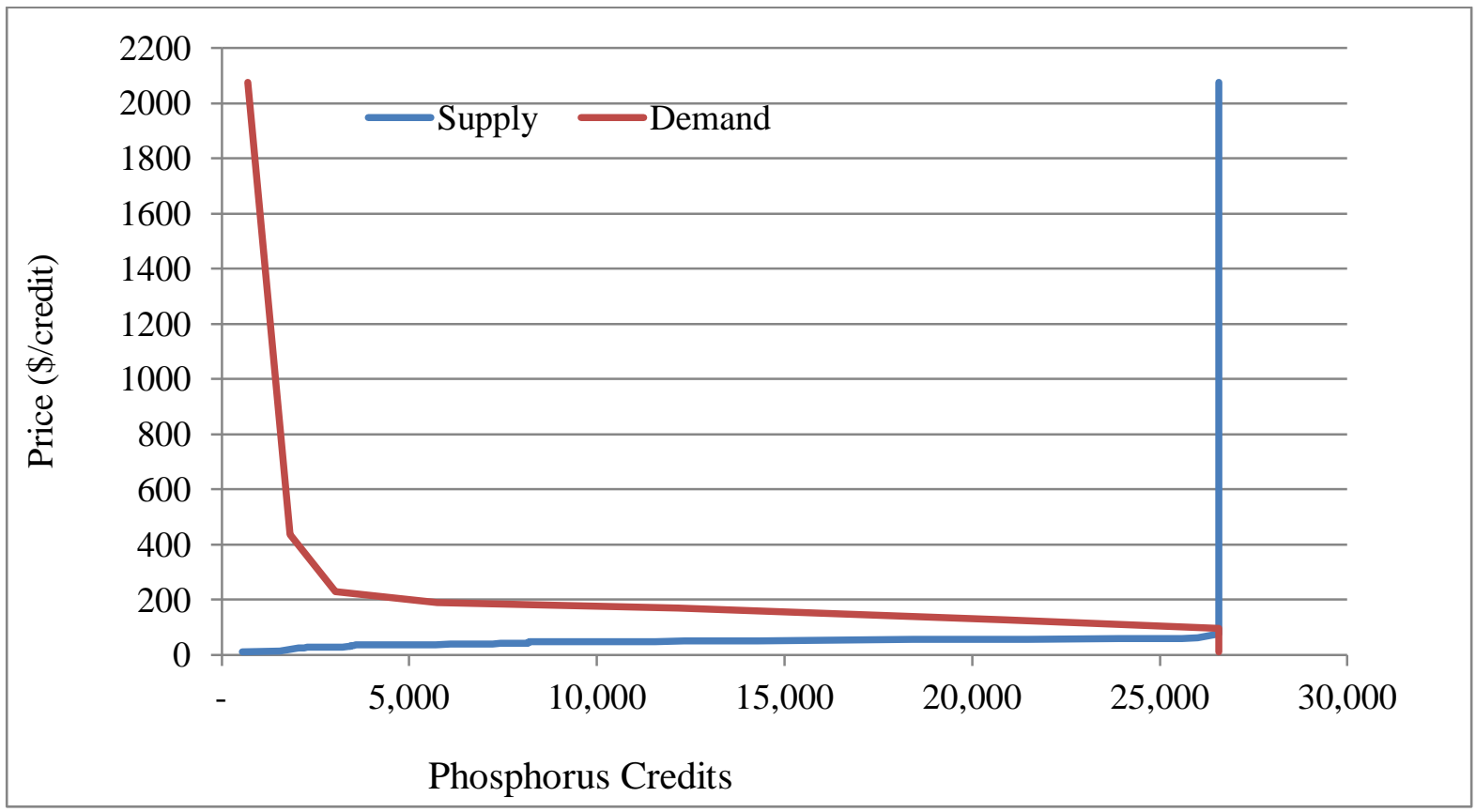

Figure C7: Potential Demand and Supply of TP Credits in a Single Nutrient Market in Scenario 3

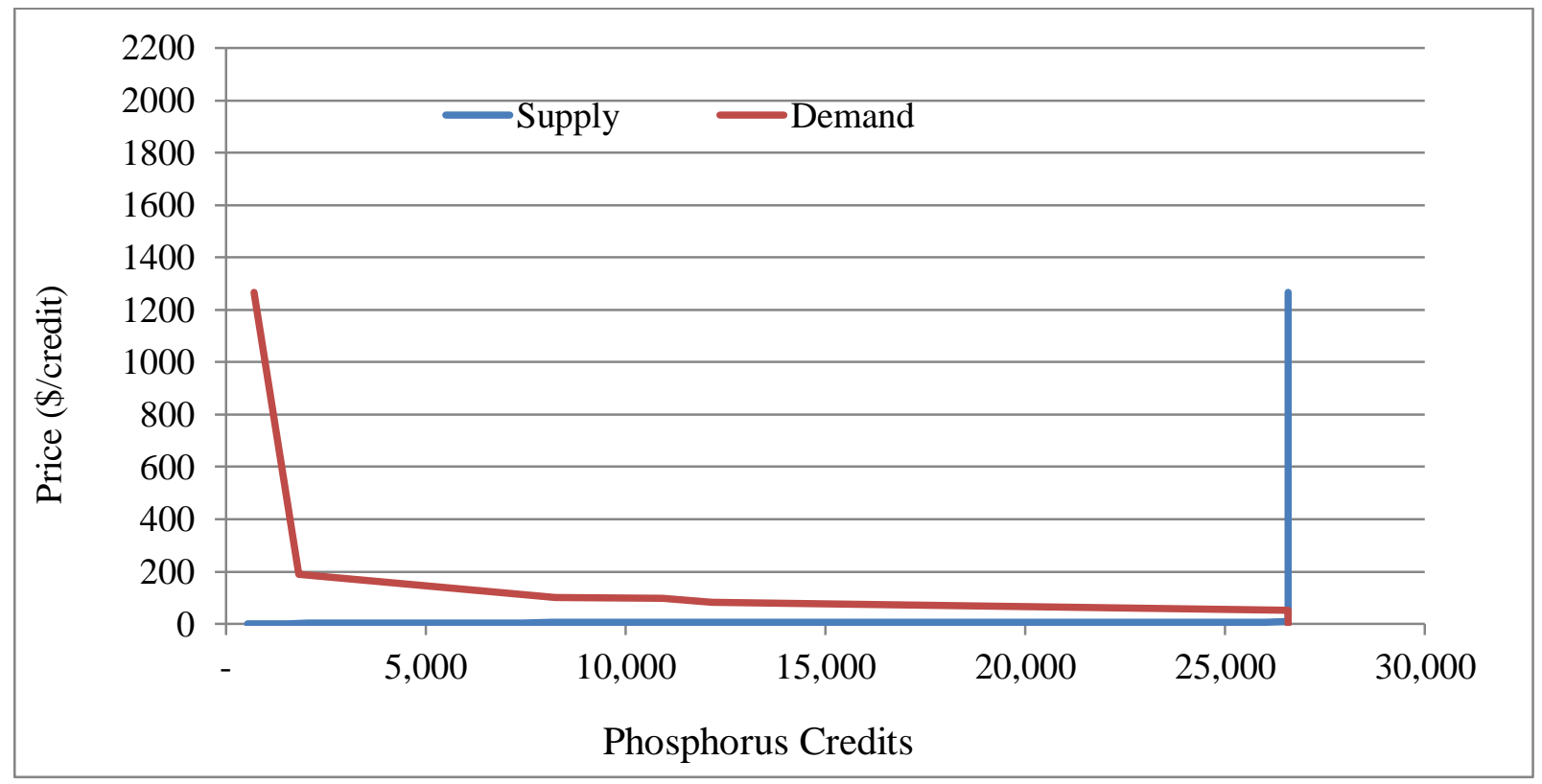

Figure C8: Potential Demand and Supply of TP Credits in a Combined Nutrient Market in Scenario 3 


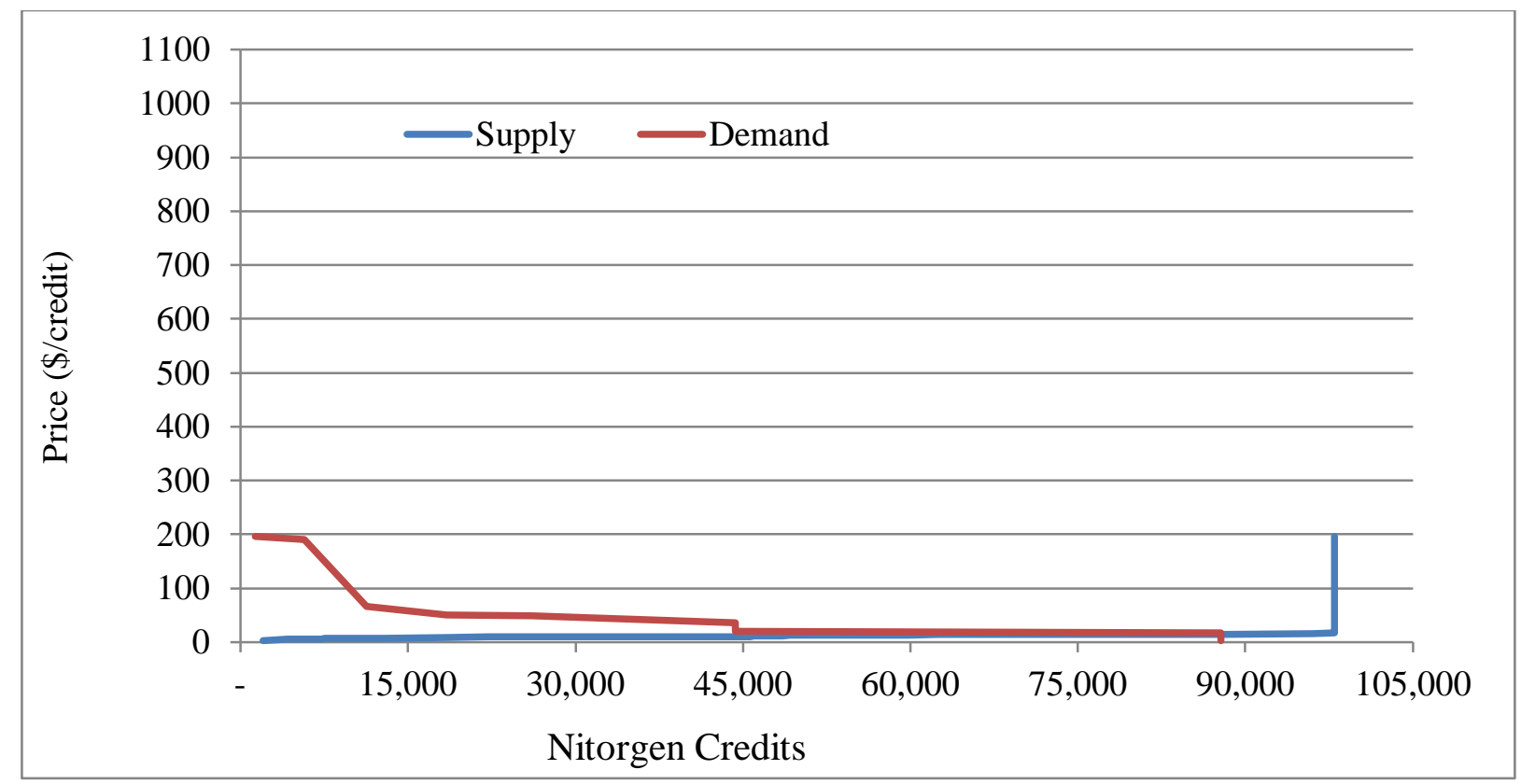

Figure C9: Potential Demand and Supply of TN Credits in a Combined Nutrient Market in Scenario 3

Scenario 4: Trading Ratio (2:1), WWTP's Effluent Limit (8.0 mg/l TN, $1.0 \mathrm{mg} / \mathrm{l} \mathrm{TP})$, and baseline requirement (Existing Level of BMPs)

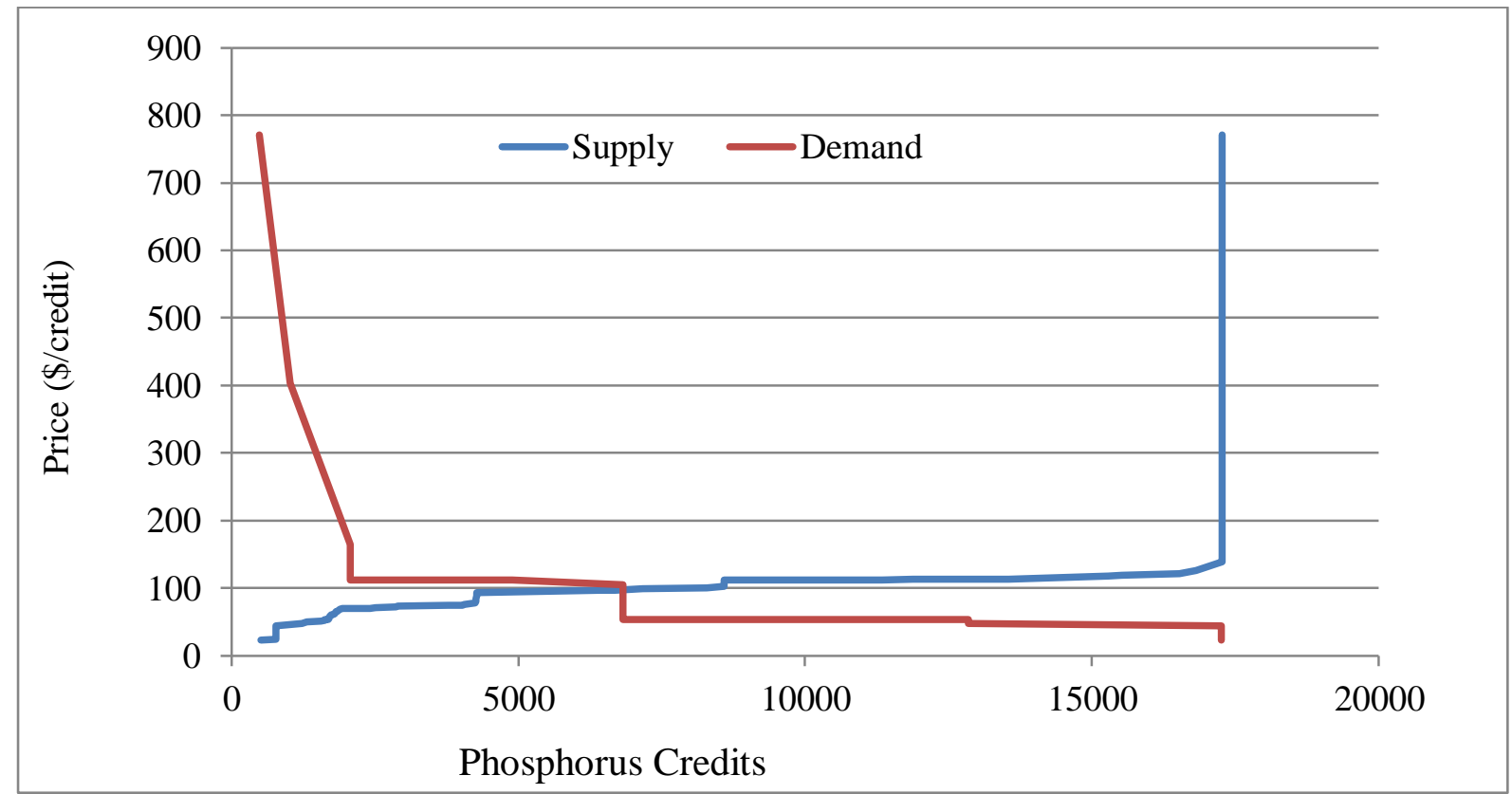

Figure C10: Potential Demand and Supply of TP Credits in a Single Nutrient Market in Scenario 4 


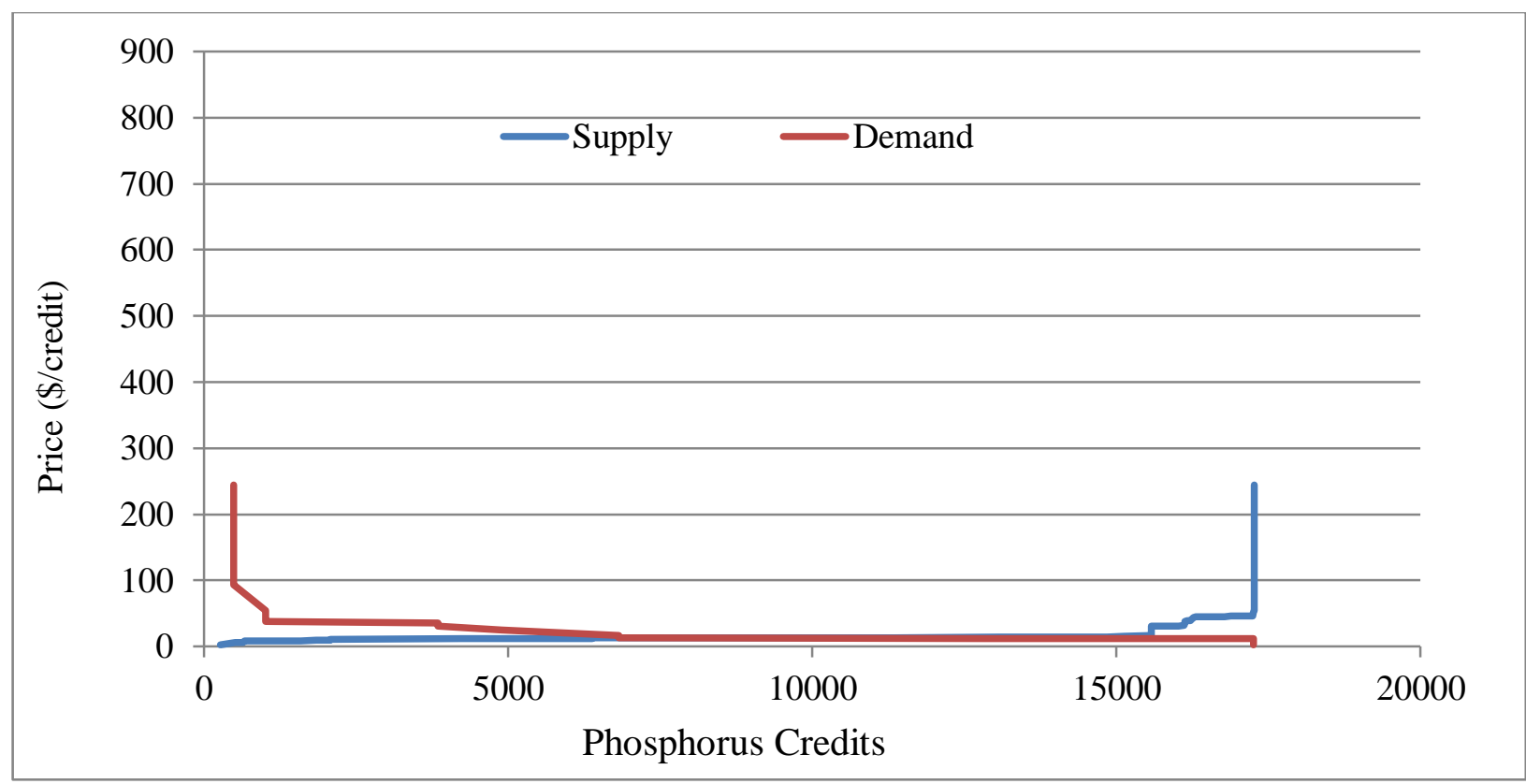

Figure C11: Potential Demand and Supply of TP Credits in a Combined Nutrient Market in Scenario 4

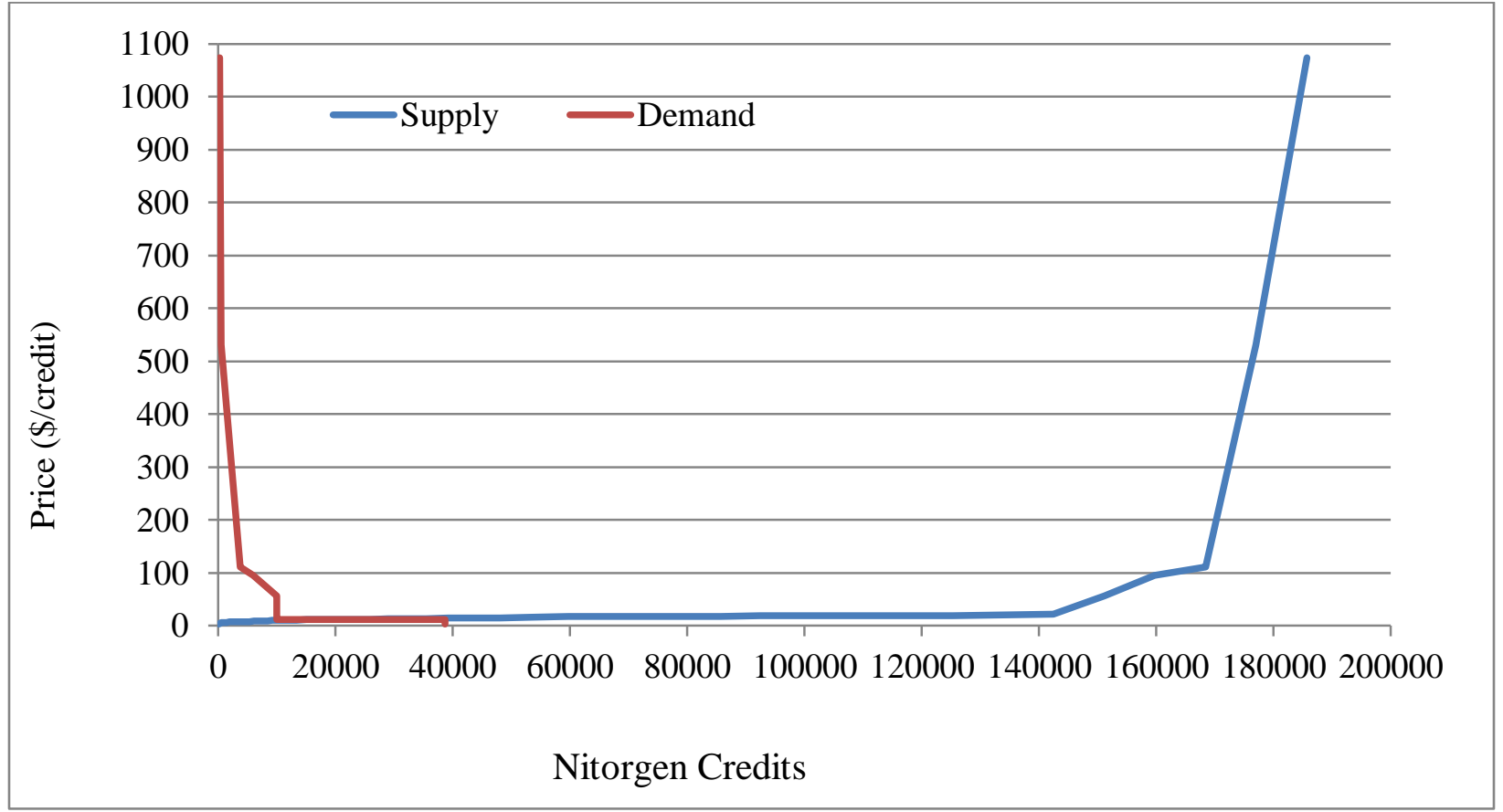

Figure C12: Potential Demand and Supply of TN Credits in a Combined Nutrient Market in Scenario 4 
Scenario 5: Trading Ratio (2:1), WWTP's Effluent Limit (5.0 $\mathrm{mg} / \mathrm{l} \mathrm{TN}, 0.5 \mathrm{mg} / \mathrm{l} \mathrm{TP}$ ), and baseline requirement (Existing Level of BMPs)

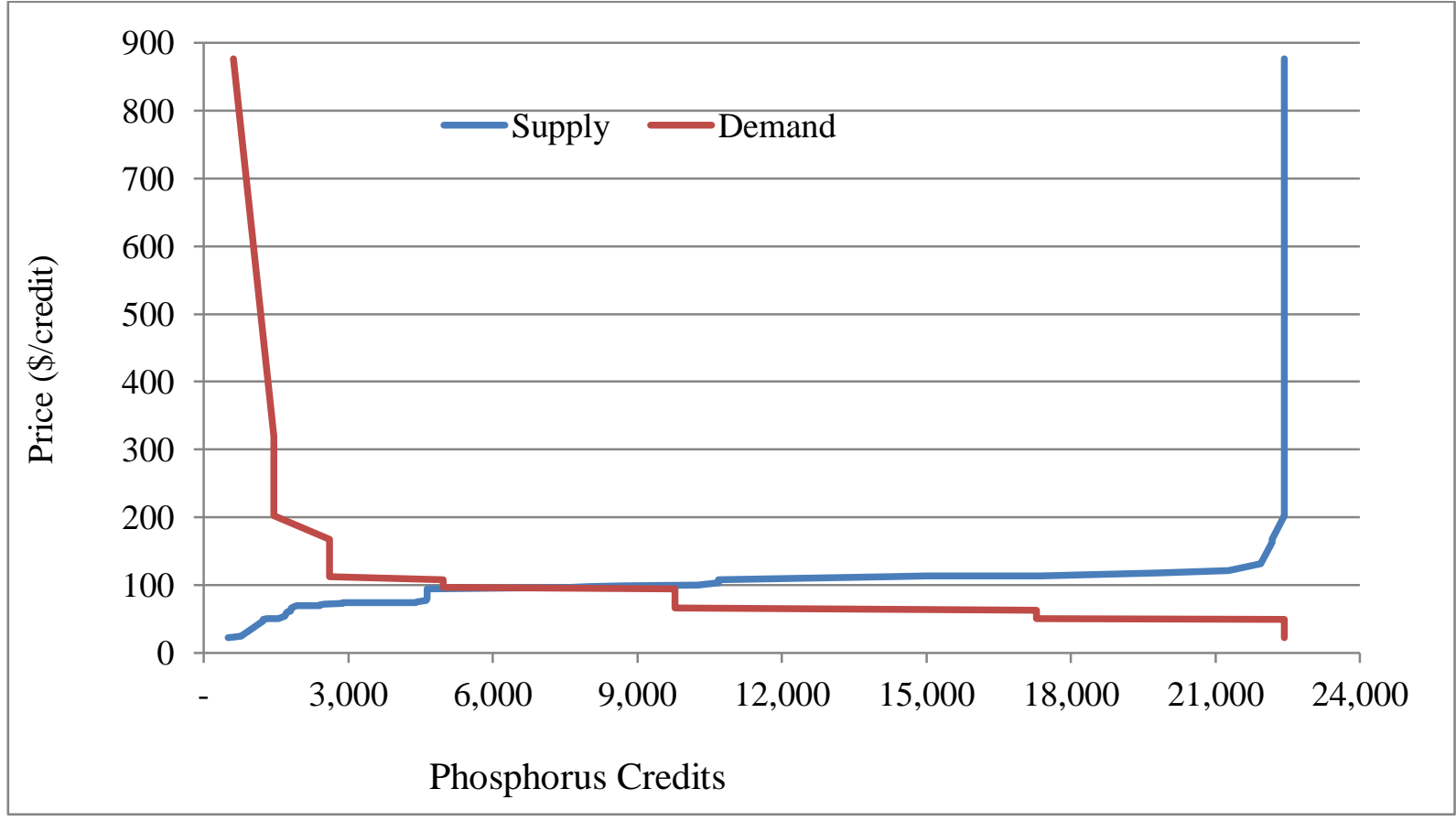

Figure C13: Potential Demand and Supply of TP Credits in a Single Nutrient Market in Scenario 5

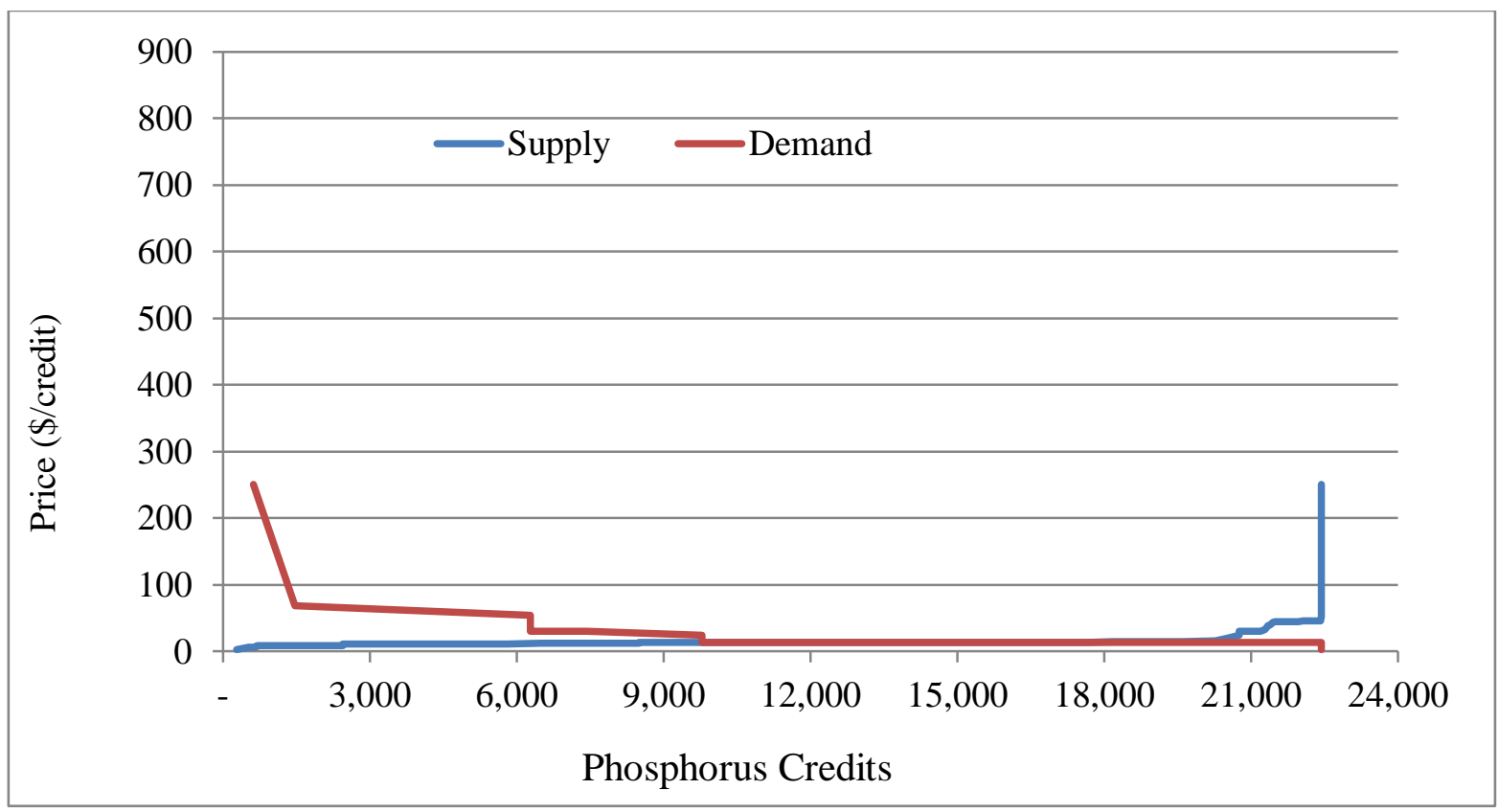

Figure C14: Potential Demand and Supply of TP Credits in a Combined Nutrient Market in Scenario5 


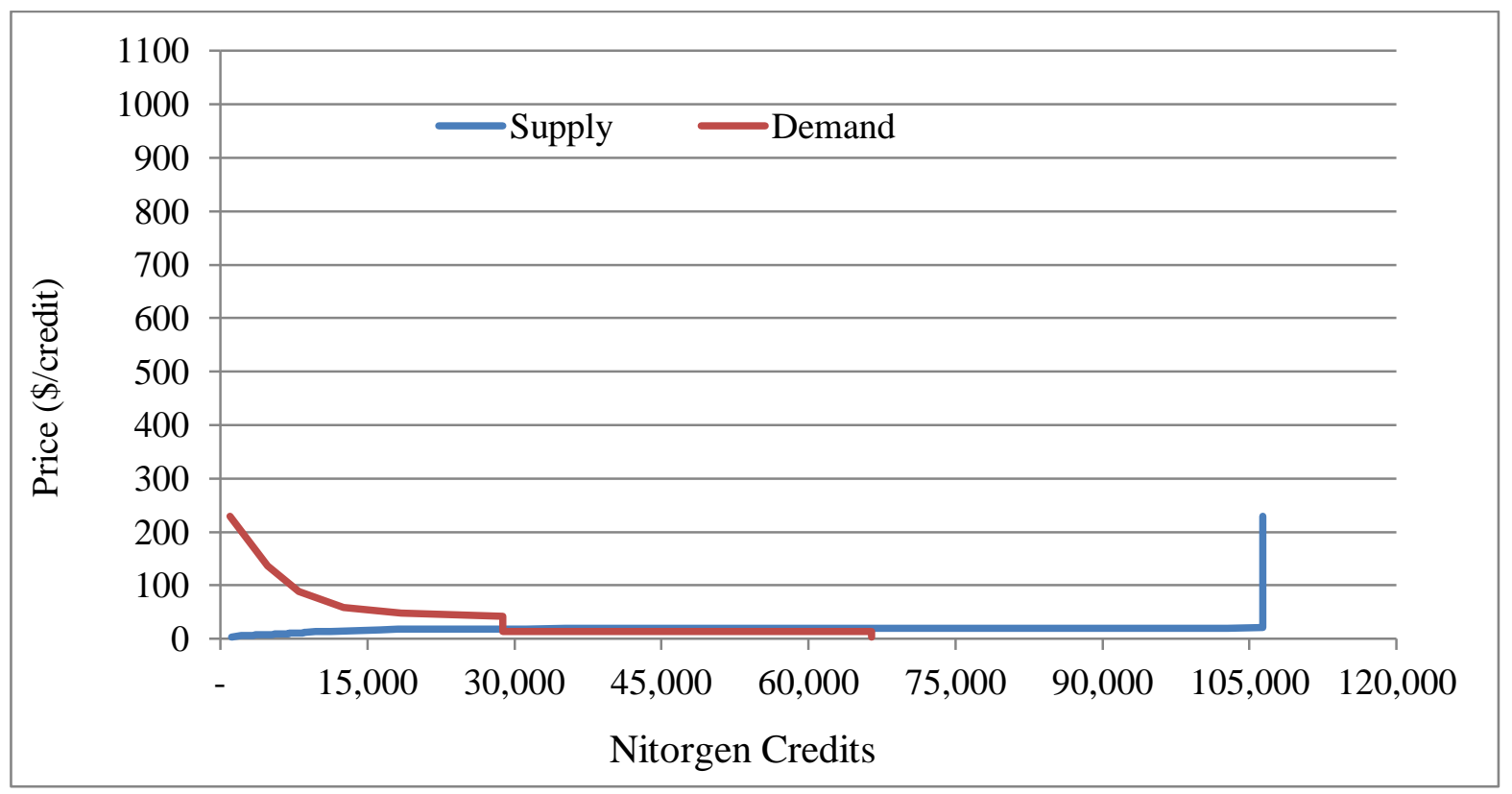

Figure C15: Potential Demand and Supply of TN Credits in a Combined Nutrient Market in Scenario 5

Scenario 6: Trading Ratio (2:1), WWTP's Effluent Limit (3.0 mg/l TN, $0.1 \mathrm{mg} / \mathrm{l} \mathrm{TP})$, and baseline requirement (Existing Level of BMPs)

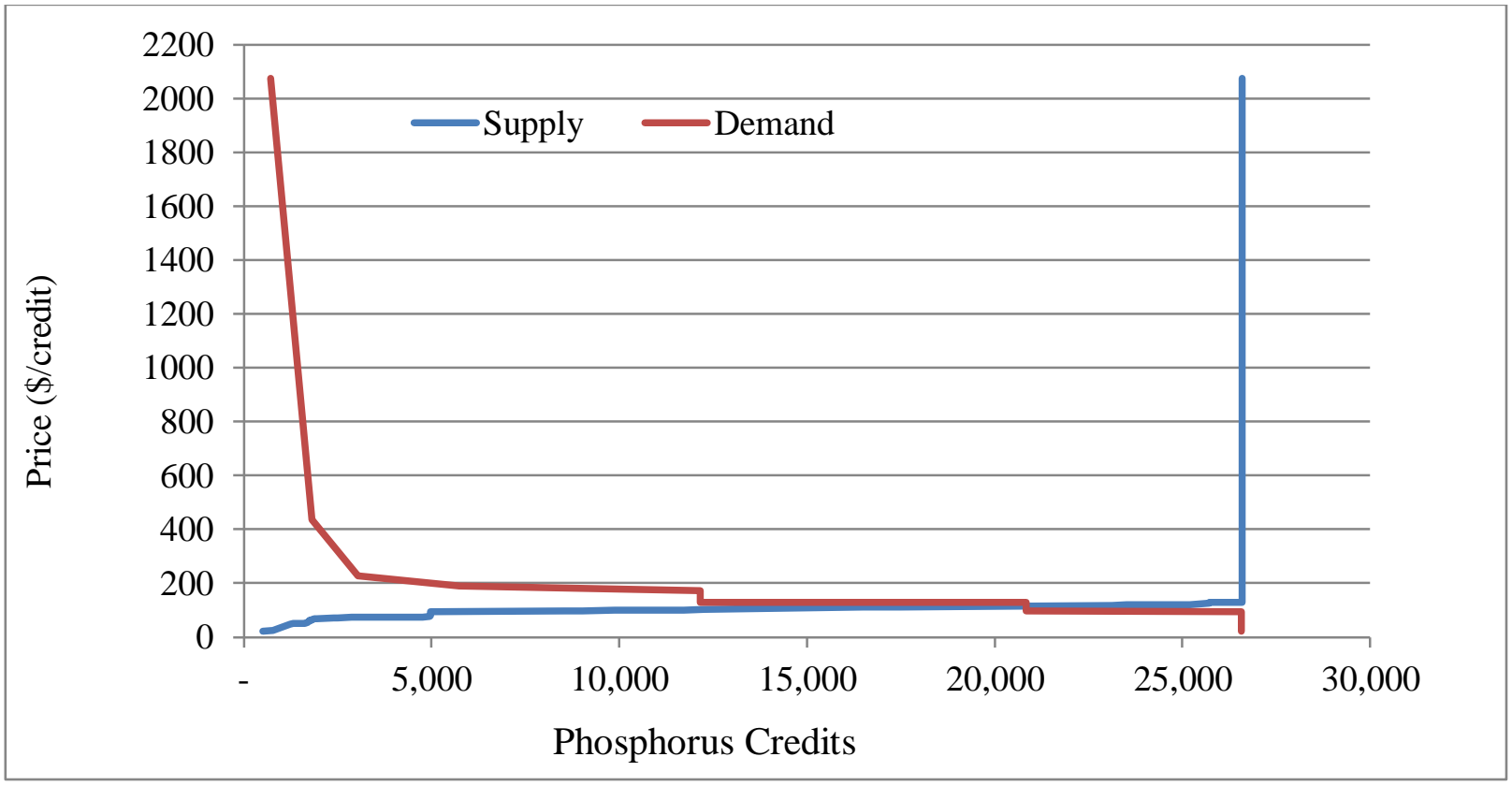

Figure C16: Potential Demand and Supply of TP Credits in a Single Nutrient Market in Scenario 6 


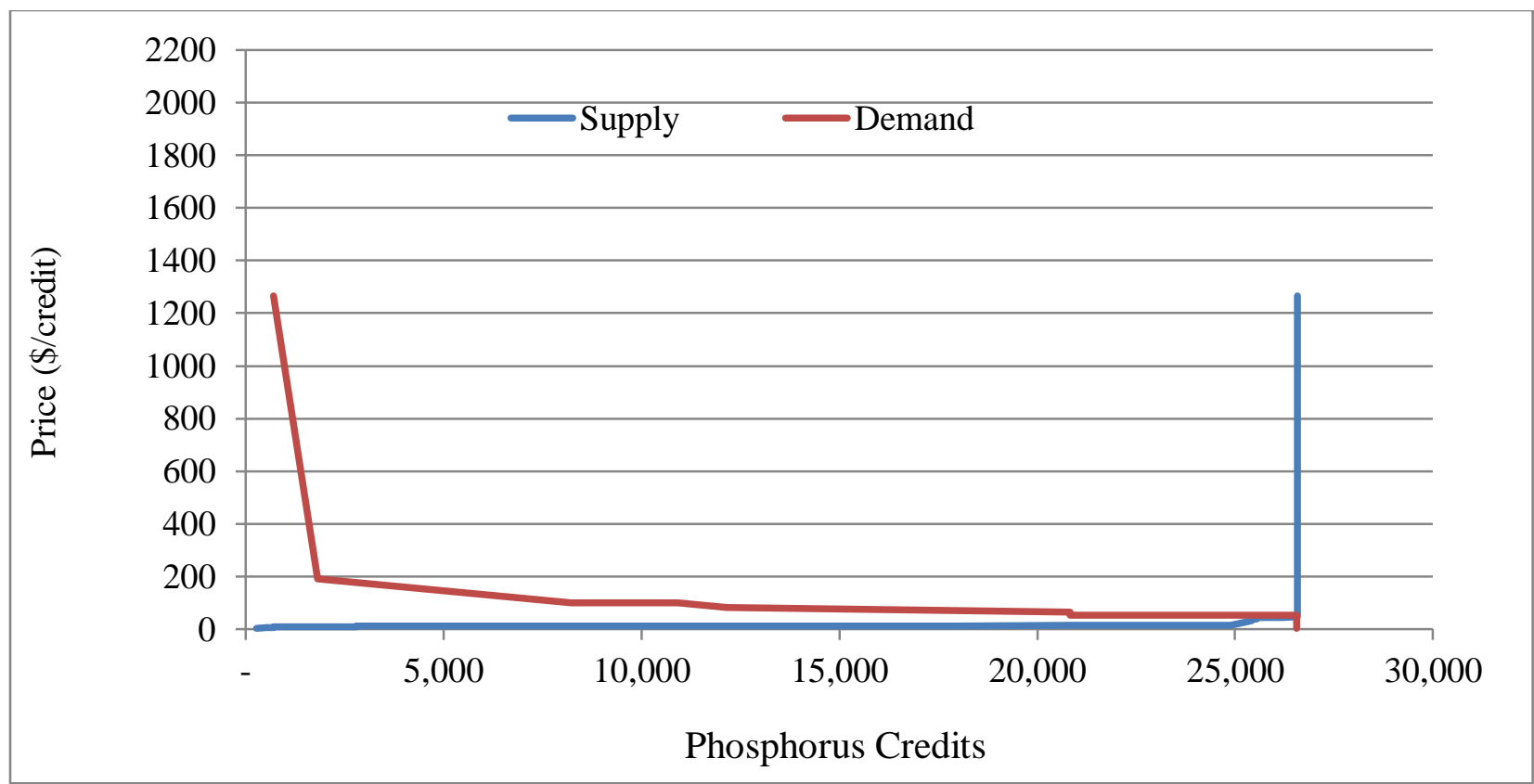

Figure C17: Potential Demand and Supply of TP Credits in a Combined Nutrient Market in Scenario 6

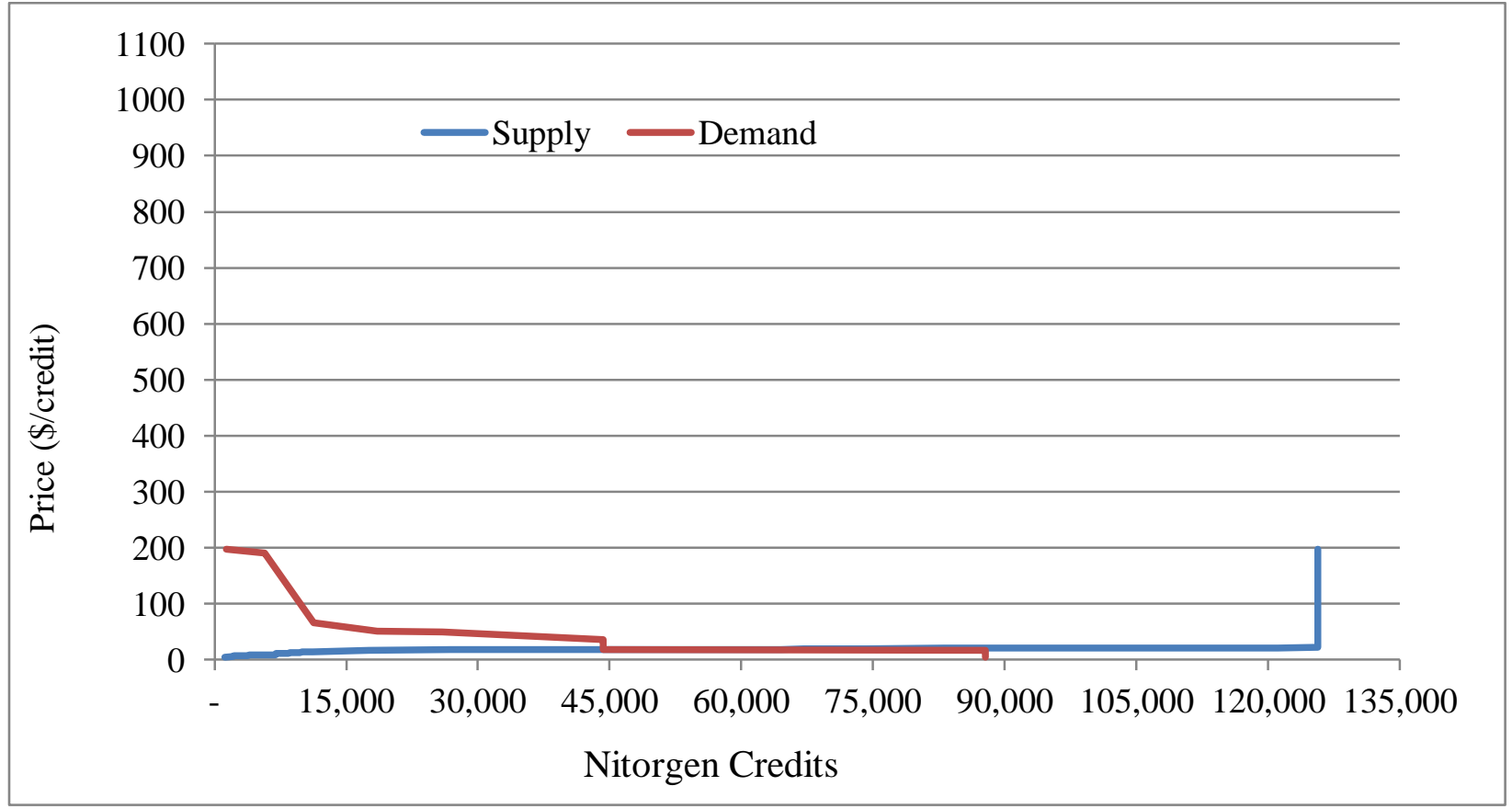

Figure C18: Potential Demand and Supply of TN Credits in a Combined Nutrient Market in Scenario 6 
Scenario 7: Trading Ratio (1:1), WWTP's Effluent Limit ( $8.0 \mathrm{mg} / \mathrm{l} \mathrm{TN}, 1 \mathrm{mg} / \mathrm{l} \mathrm{TP})$, and baseline requirement (100\% Nutrient Management Plan)

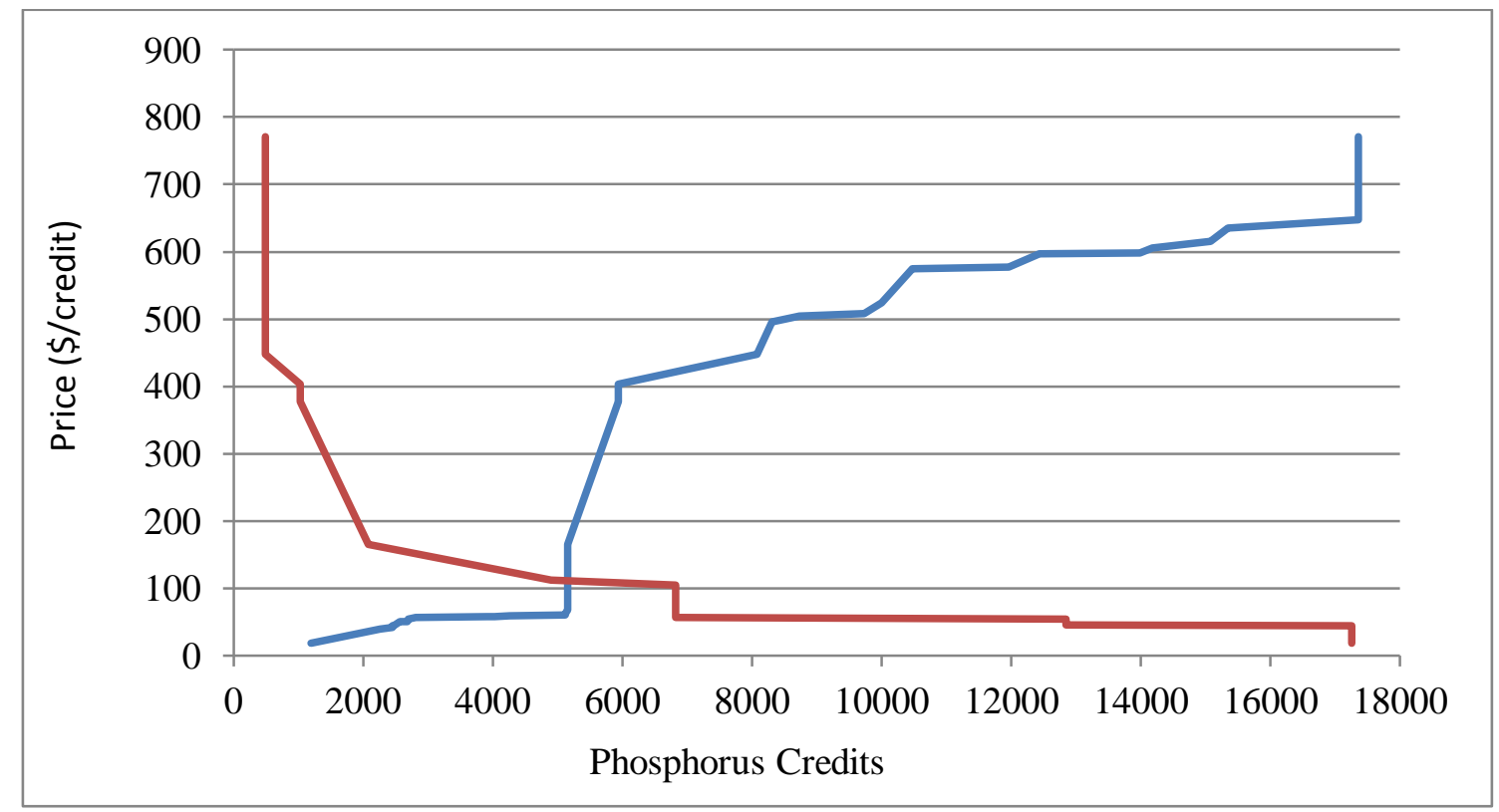

Figure C19: Potential Demand and Supply of TP Credits in a Single Nutrient Market in Scenario 7

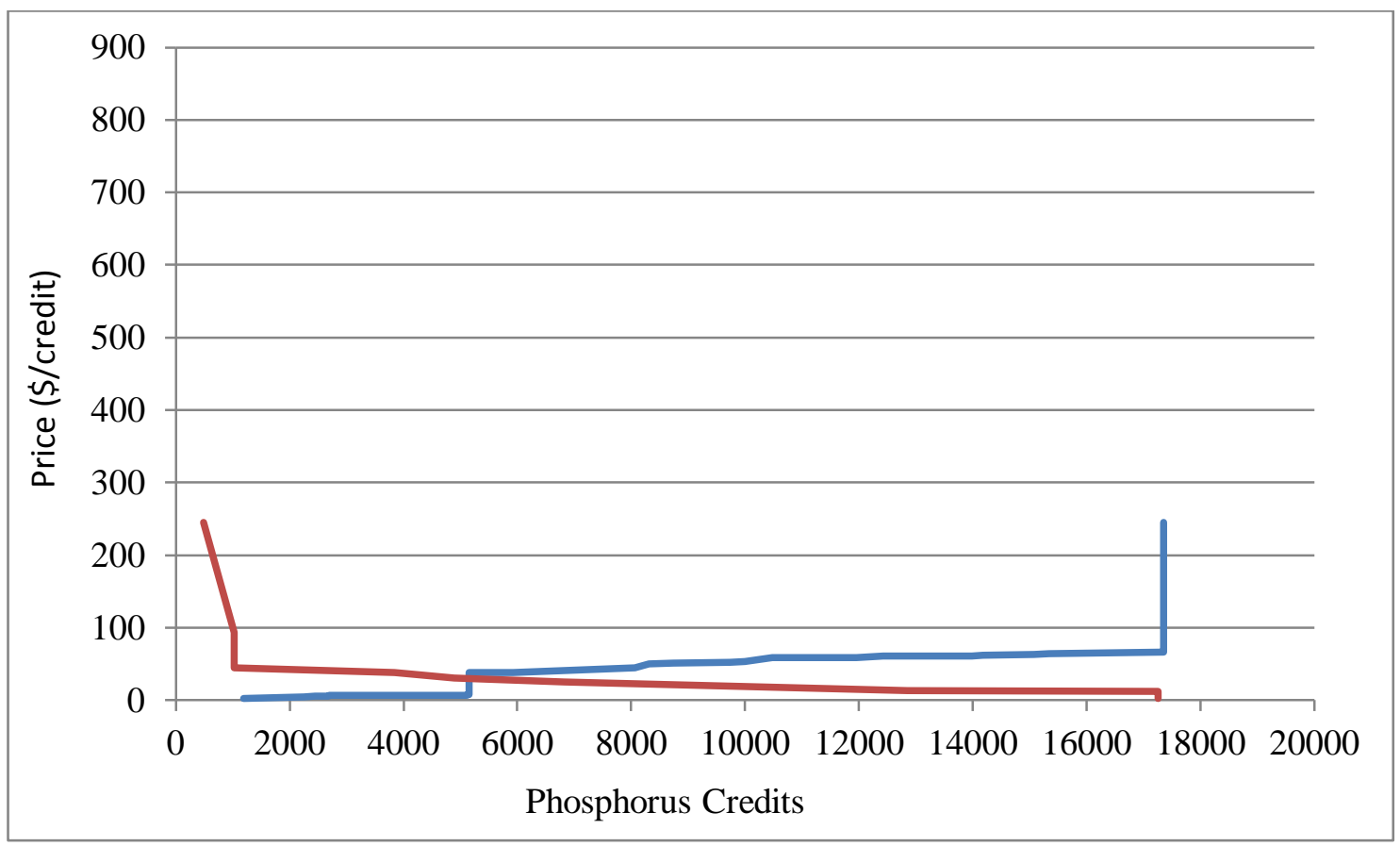

Figure C20: Potential Demand and Supply of TP Credits in a Combined Nutrient Market in Scenario 7 


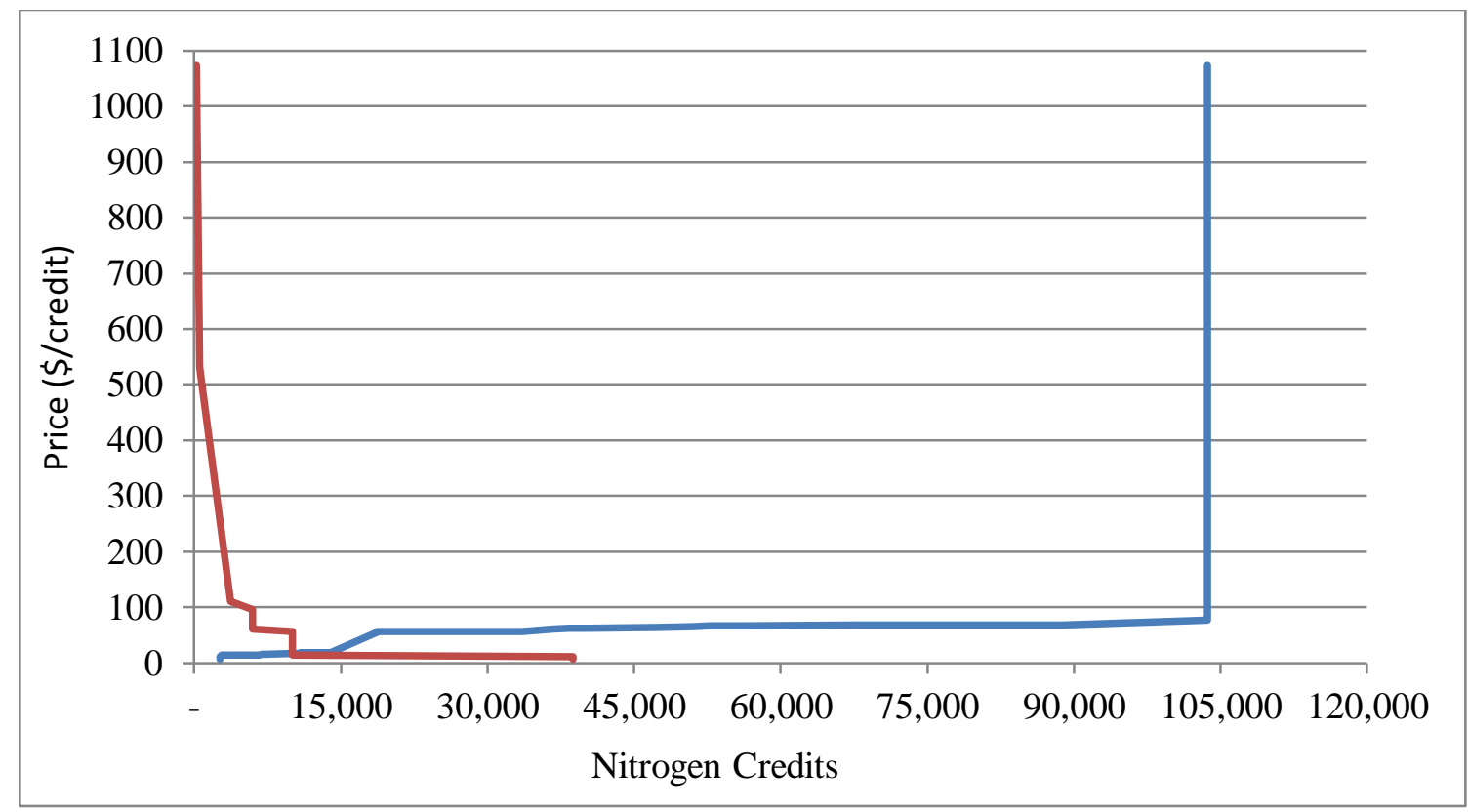

Figure C21: Potential Demand and Supply of TN Credits in a Combined Nutrient Market in Scenario 7

Scenario 8: Trading Ratio (1:1), WWTP's Effluent Limit (5.0 mg/l TN, $0.5 \mathrm{mg} / \mathrm{l} \mathrm{TP})$, and baseline requirement (100\% Nutrient Management Plan

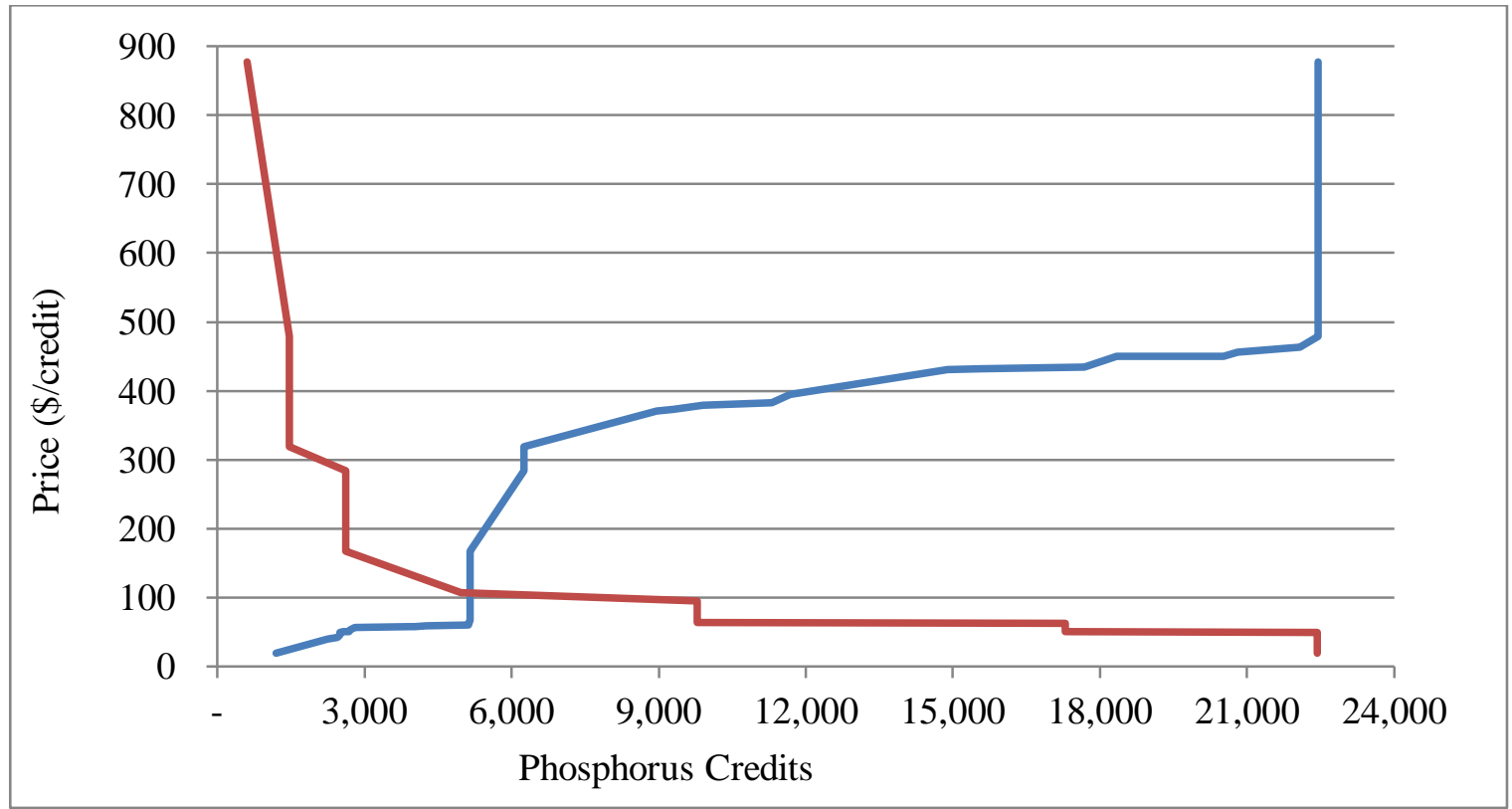

Figure C22: Potential Demand and Supply of TP Credits in a Single Nutrient Market in Scenario 8 


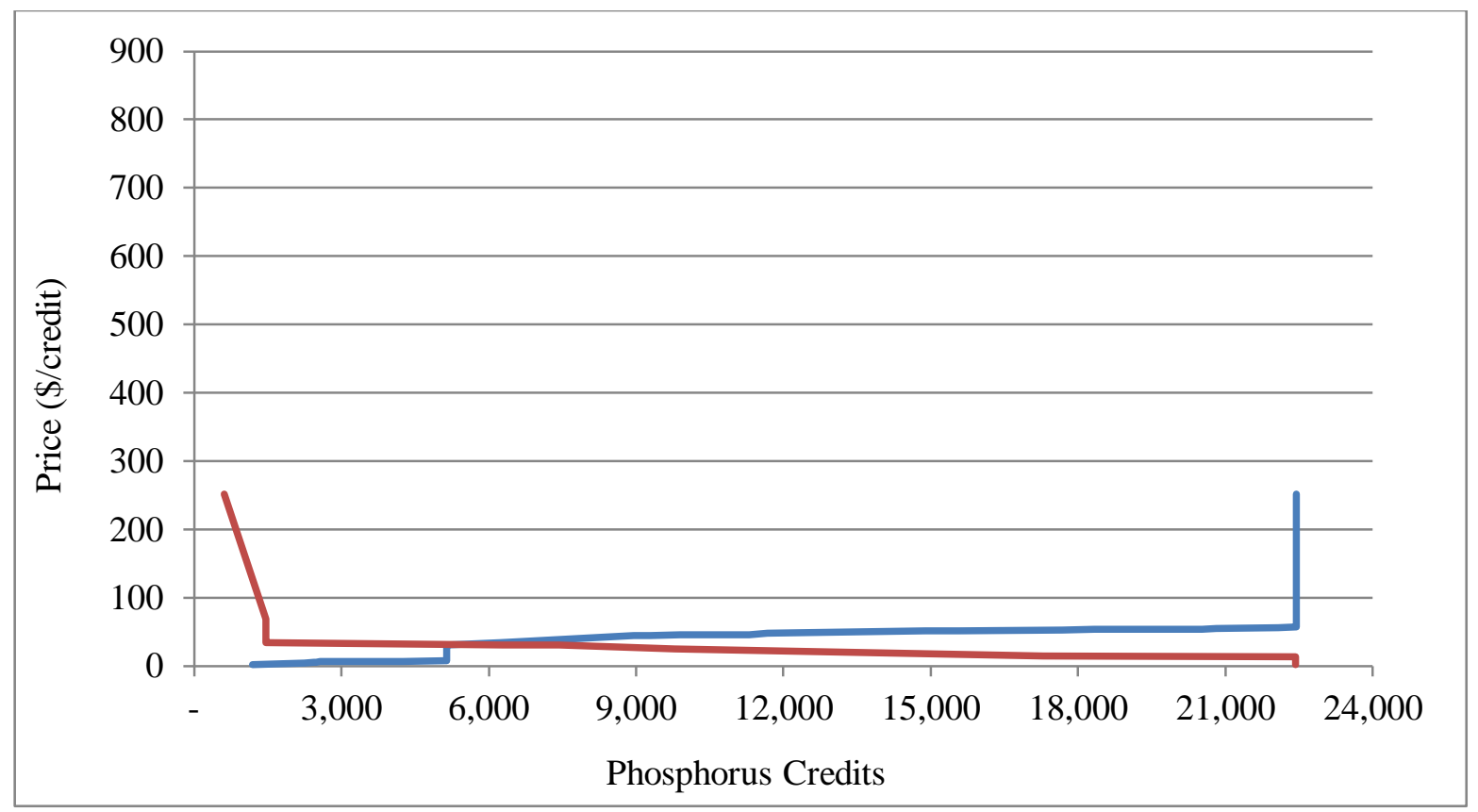

Figure C23: Potential Demand and Supply of TP Credits in a Combined Nutrient Market in Scenario 8

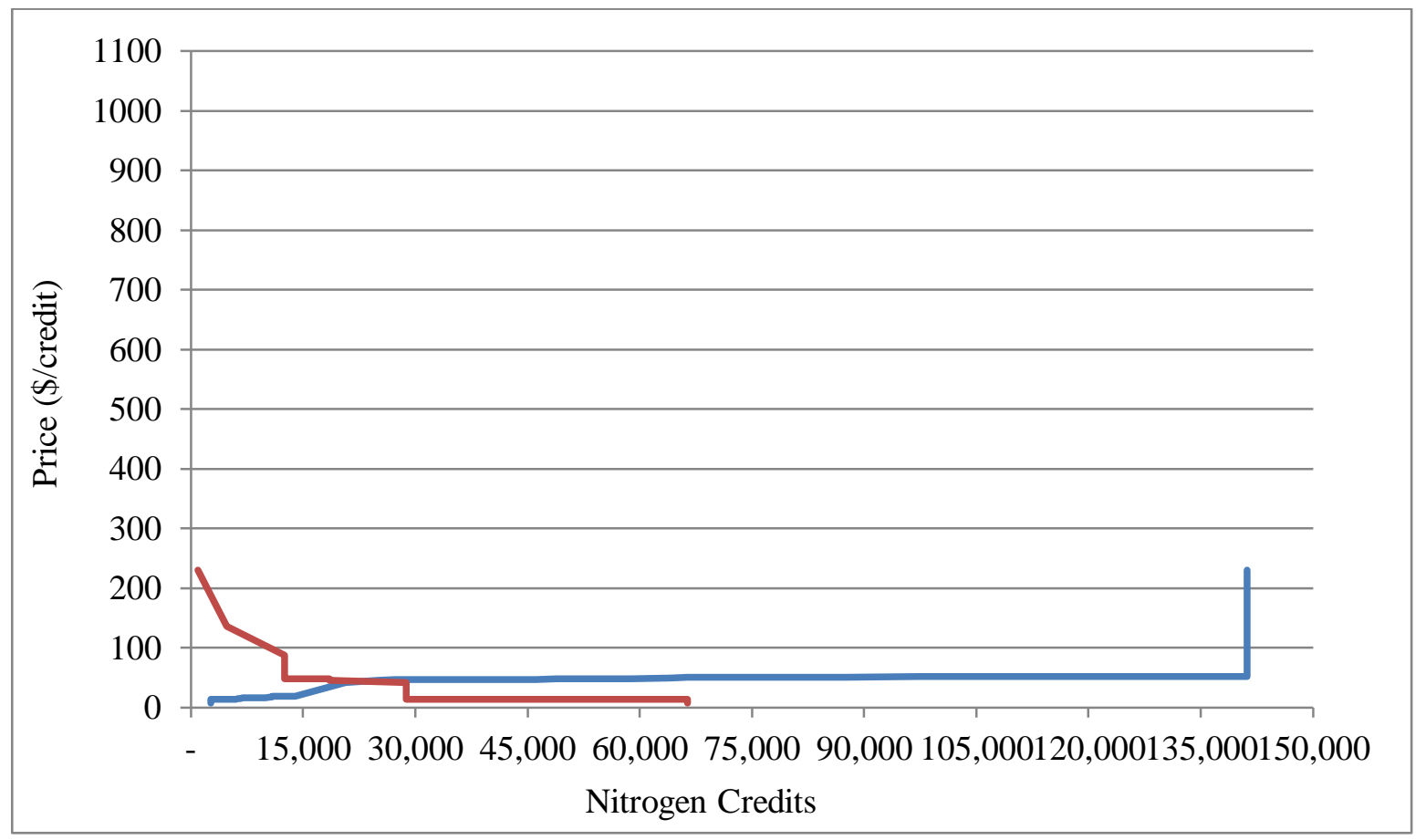

Figure C24: Potential Demand and Supply of TN Credits in a Combined Nutrient Market in Scenario 8 
Scenario 9: Trading Ratio (1:1), WWTP's Effluent Limit (3.0 mg/l TN, $0.1 \mathrm{mg} / \mathrm{l} \mathrm{TP}$ ), and baseline requirement (100\% Nutrient Management Plan

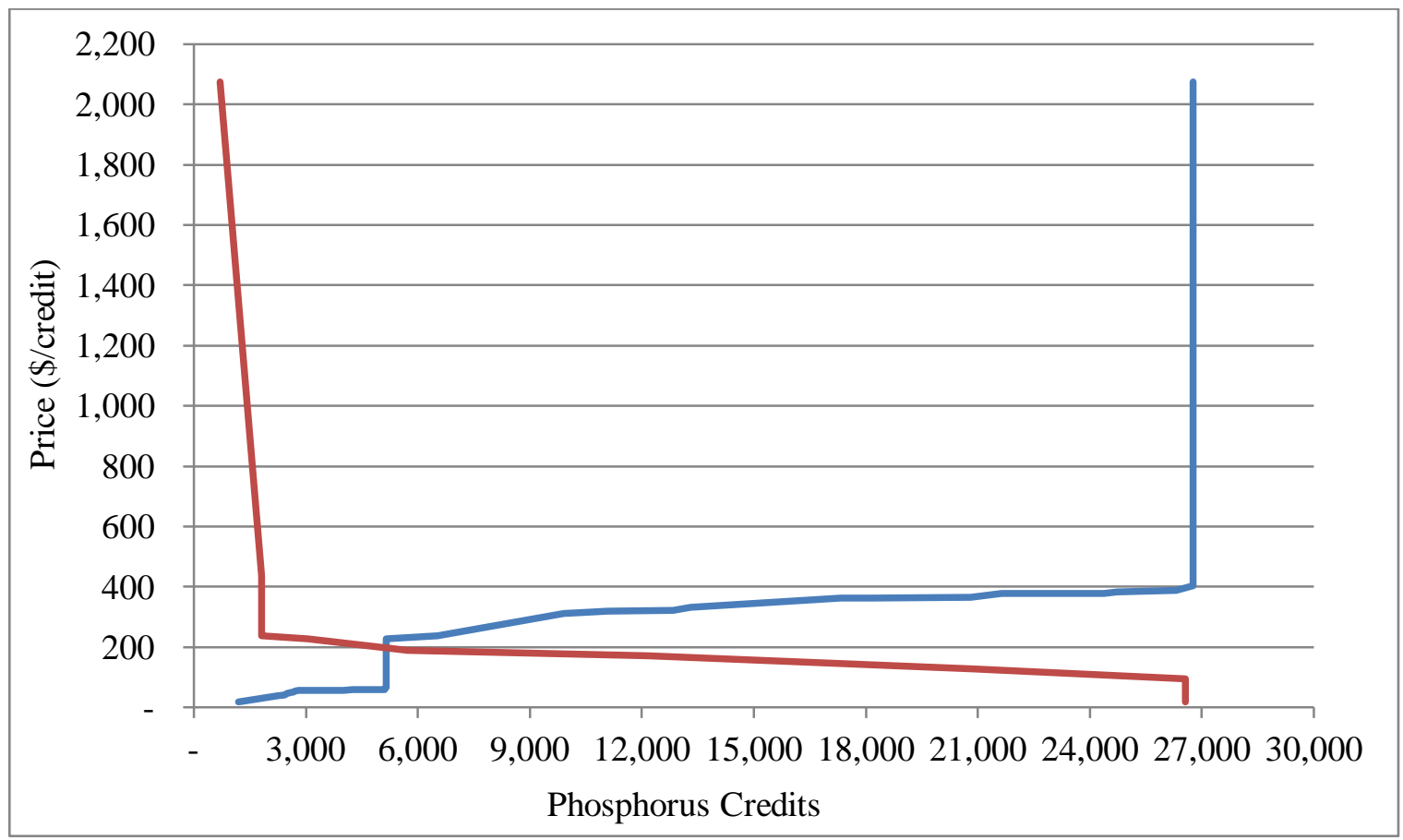

Figure C25: Potential Demand and Supply of TP Credits in a Single Nutrient Market in Scenario 9

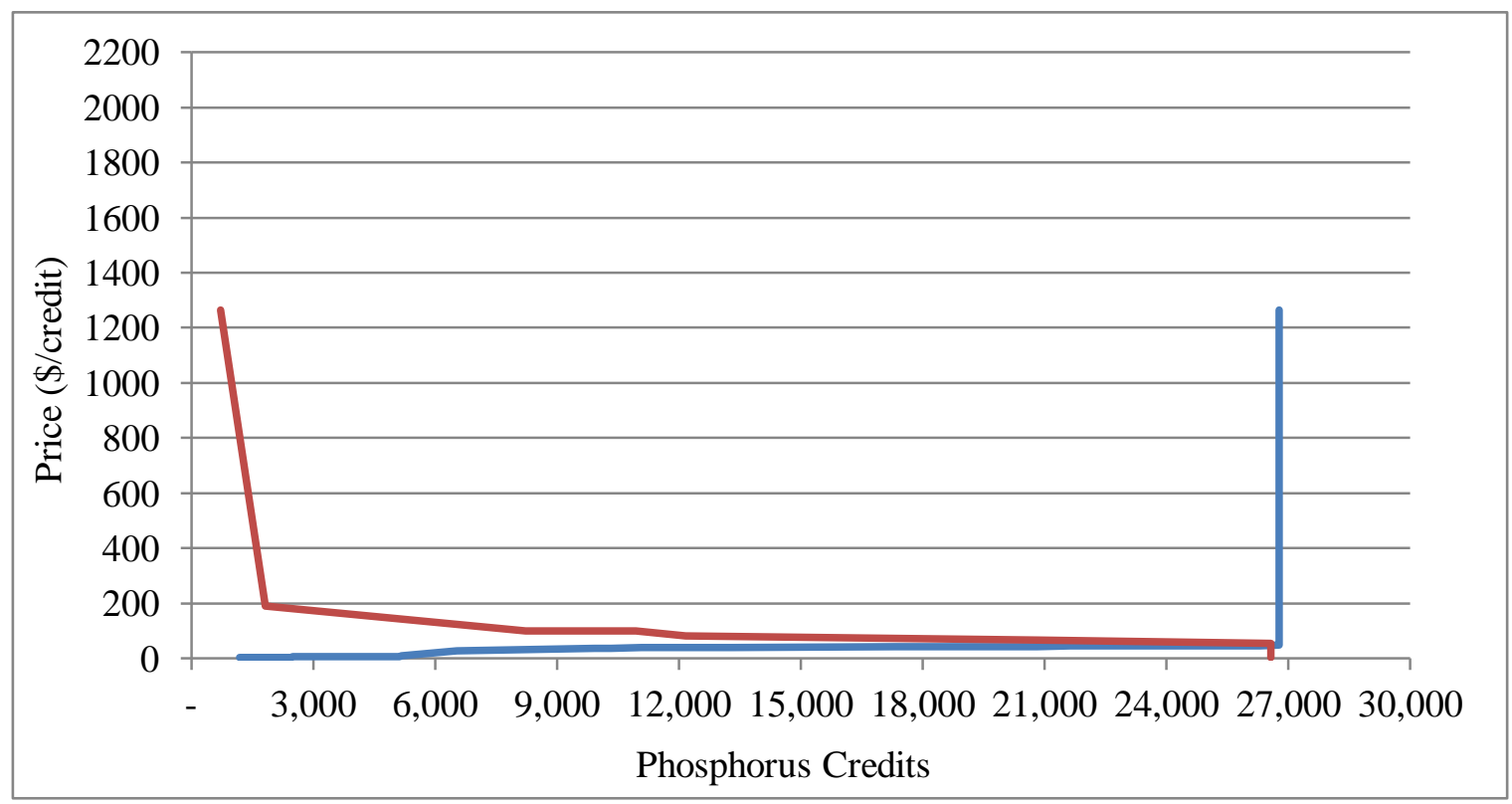

Figure C26: Potential Demand and Supply of TP Credits in a Combined Nutrient Market in Scenario 9 


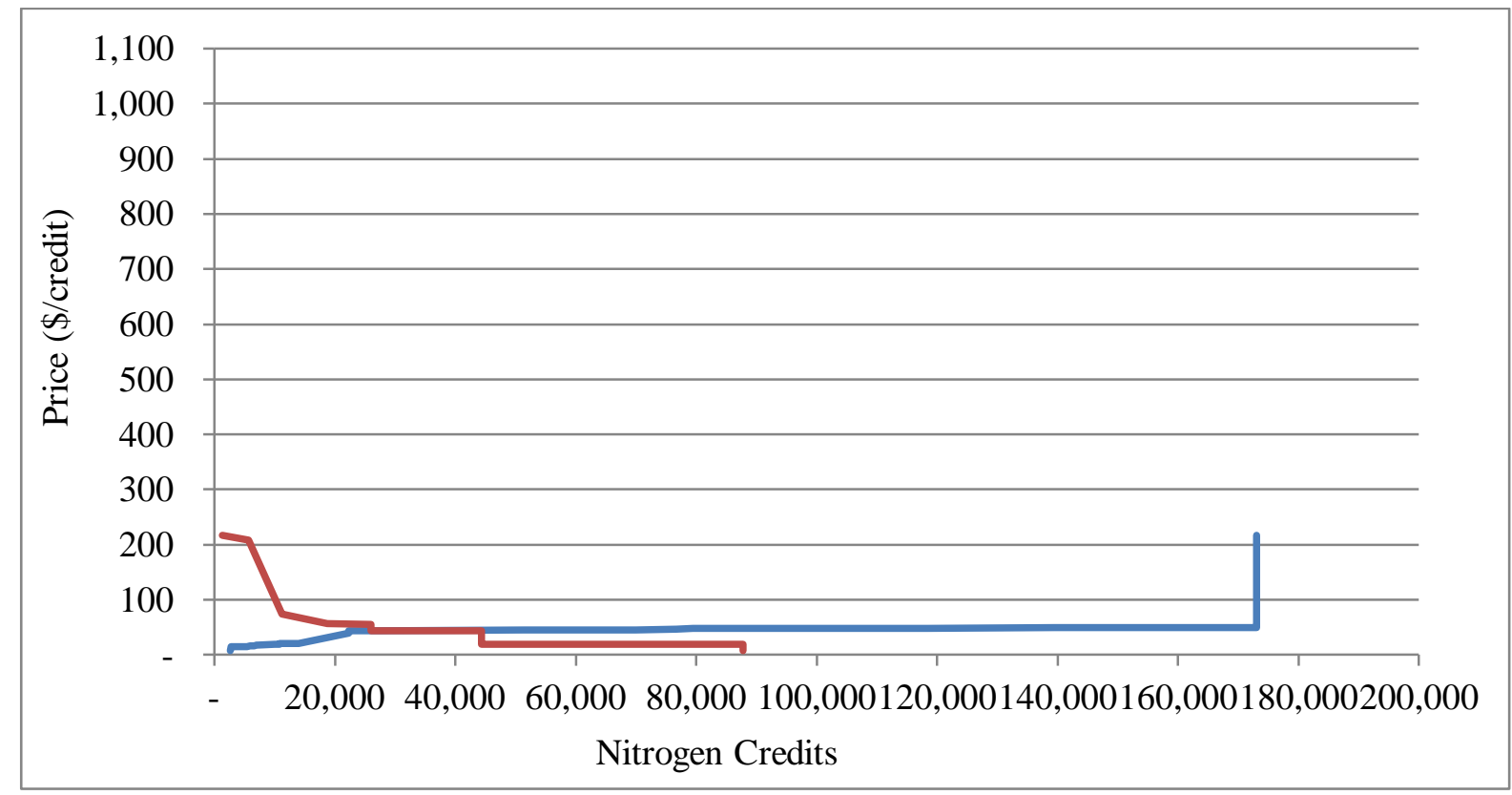

Figure C27: Potential Demand and Supply of TN Credits in a Combined Nutrient Market in Scenario 9

Scenario 10: Trading Ratio (2:1), WWTP's Effluent Limit (8.0 mg/l TN, $1 \mathrm{mg} / \mathrm{l} \mathrm{TP}$ ), and baseline requirement (100\% Nutrient Management Plan

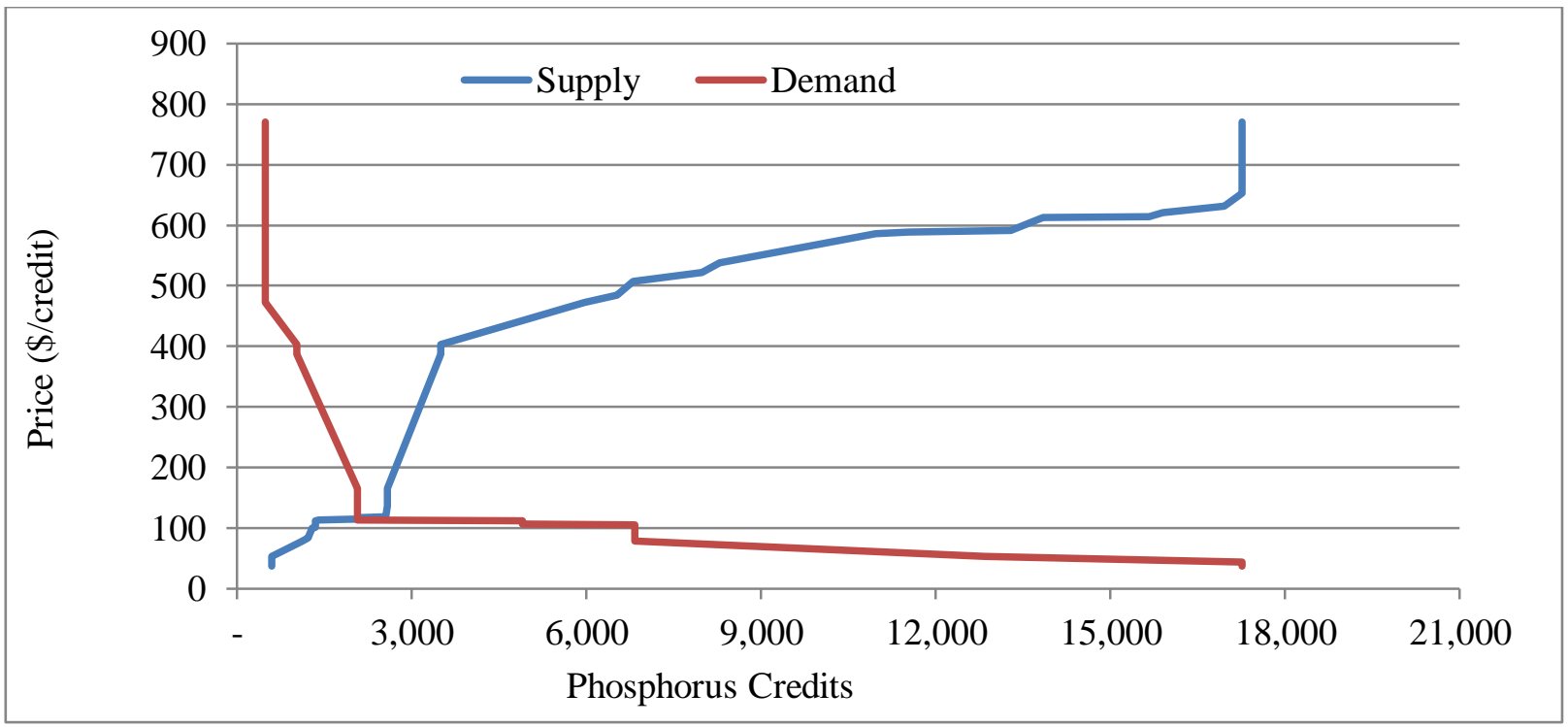

Figure C28: Potential Demand and Supply of TP Credits in a Single Nutrient Market in Scenario 10 


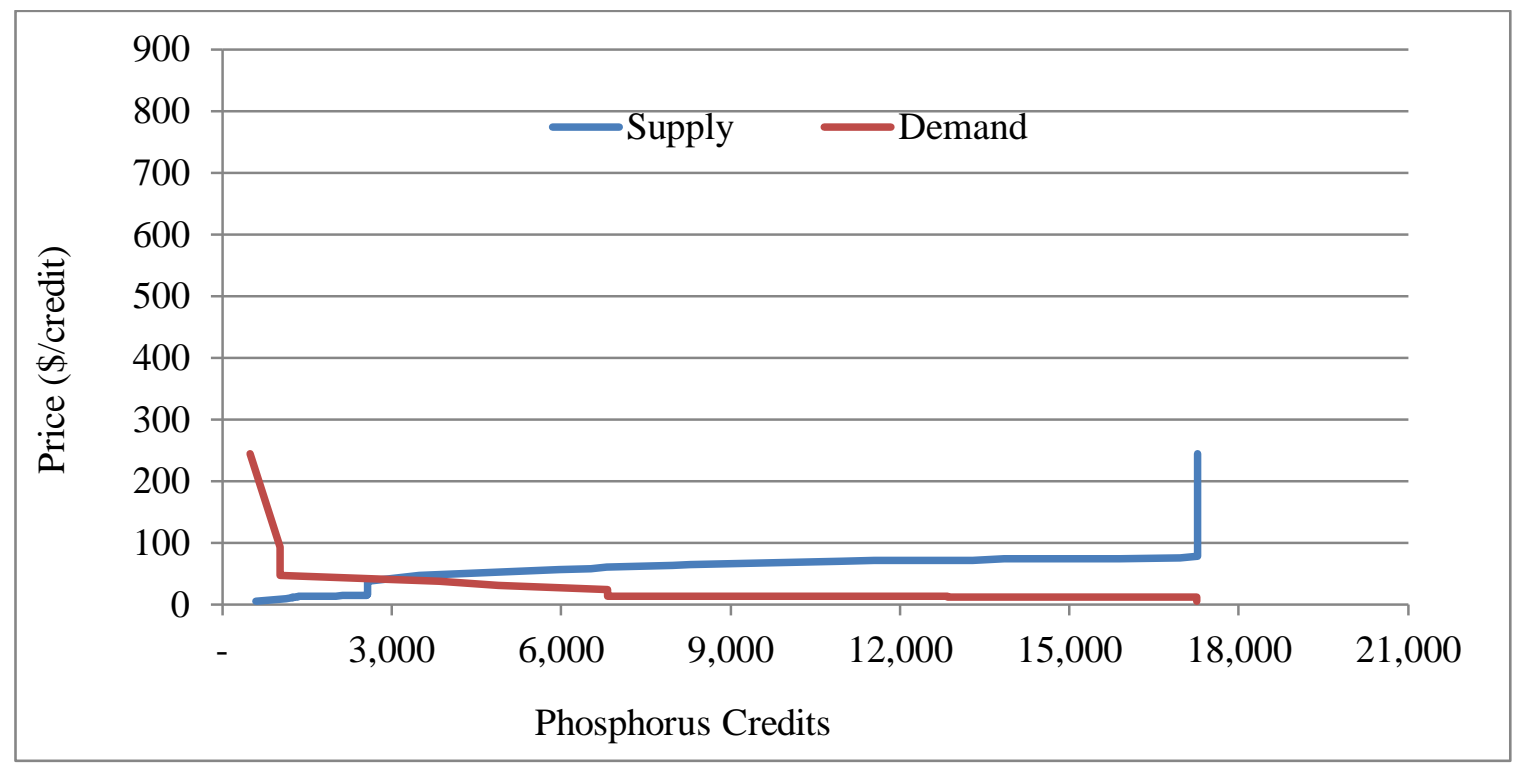

Figure C29: Potential Demand and Supply of TP Credits in a Combined Nutrient Market in Scenario 10

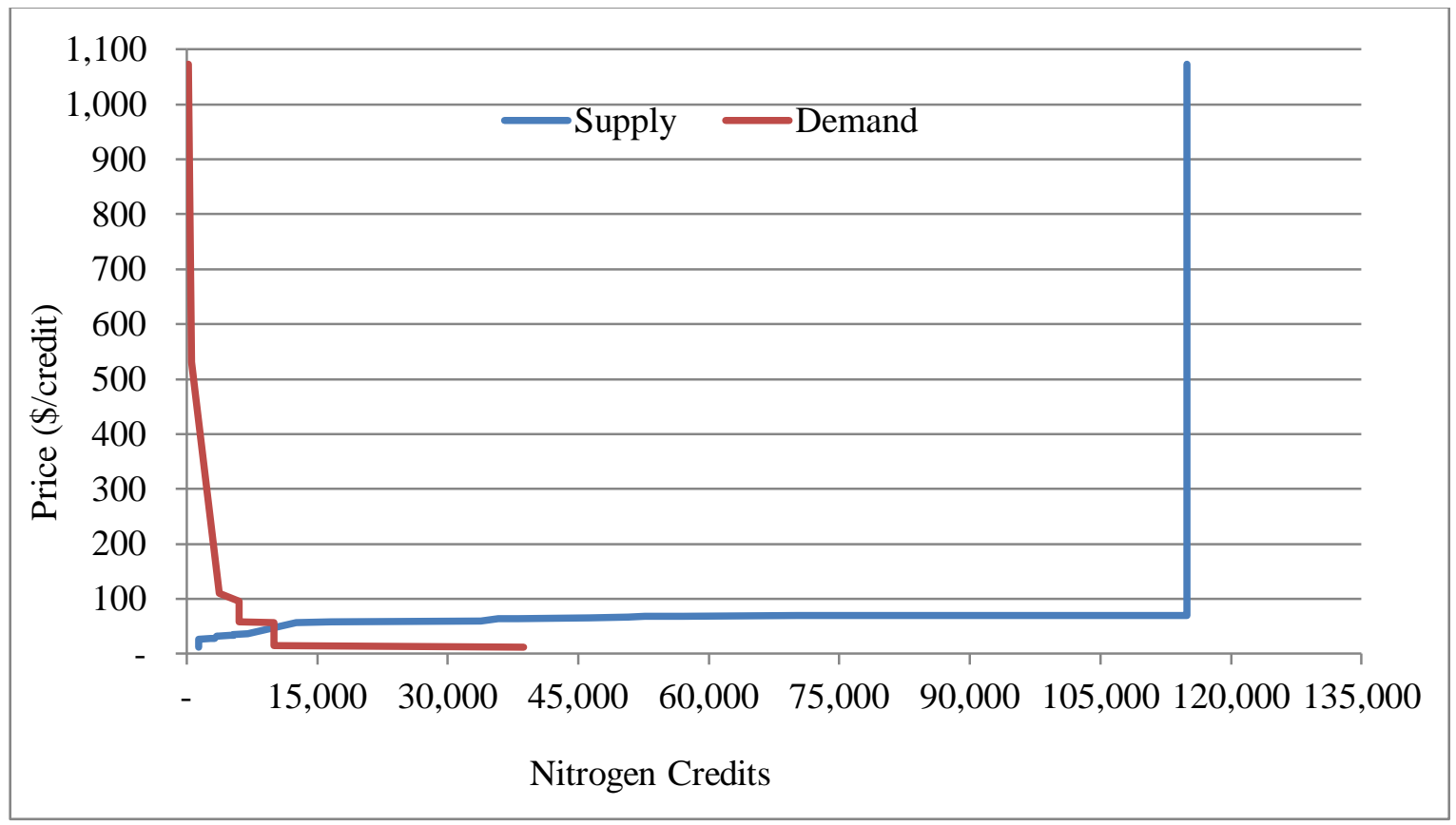

Figure C30: Potential Demand and Supply of TN Credits in a Combined Nutrient Market in Scenario 10 
Scenario 11: Trading Ratio (2:1), WWTP's Effluent Limit (5.0 $\mathrm{mg} / \mathrm{l} \mathrm{TN}, 0.5 \mathrm{mg} / \mathrm{l} \mathrm{TP})$, and baseline requirement (100\% Nutrient Management Plan

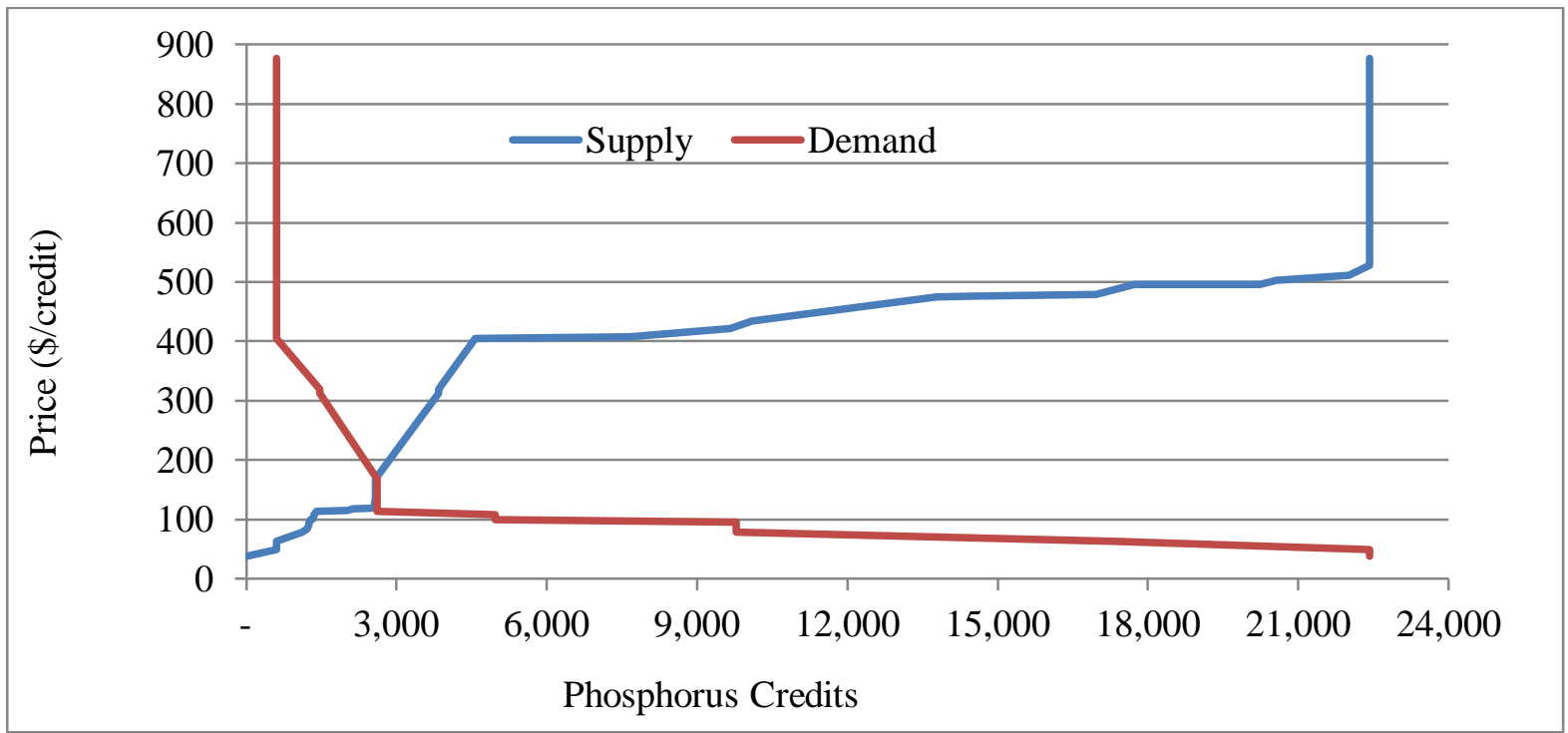

Figure C31: Potential Demand and Supply of TP Credits in a Single Nutrient Market in Scenario 11

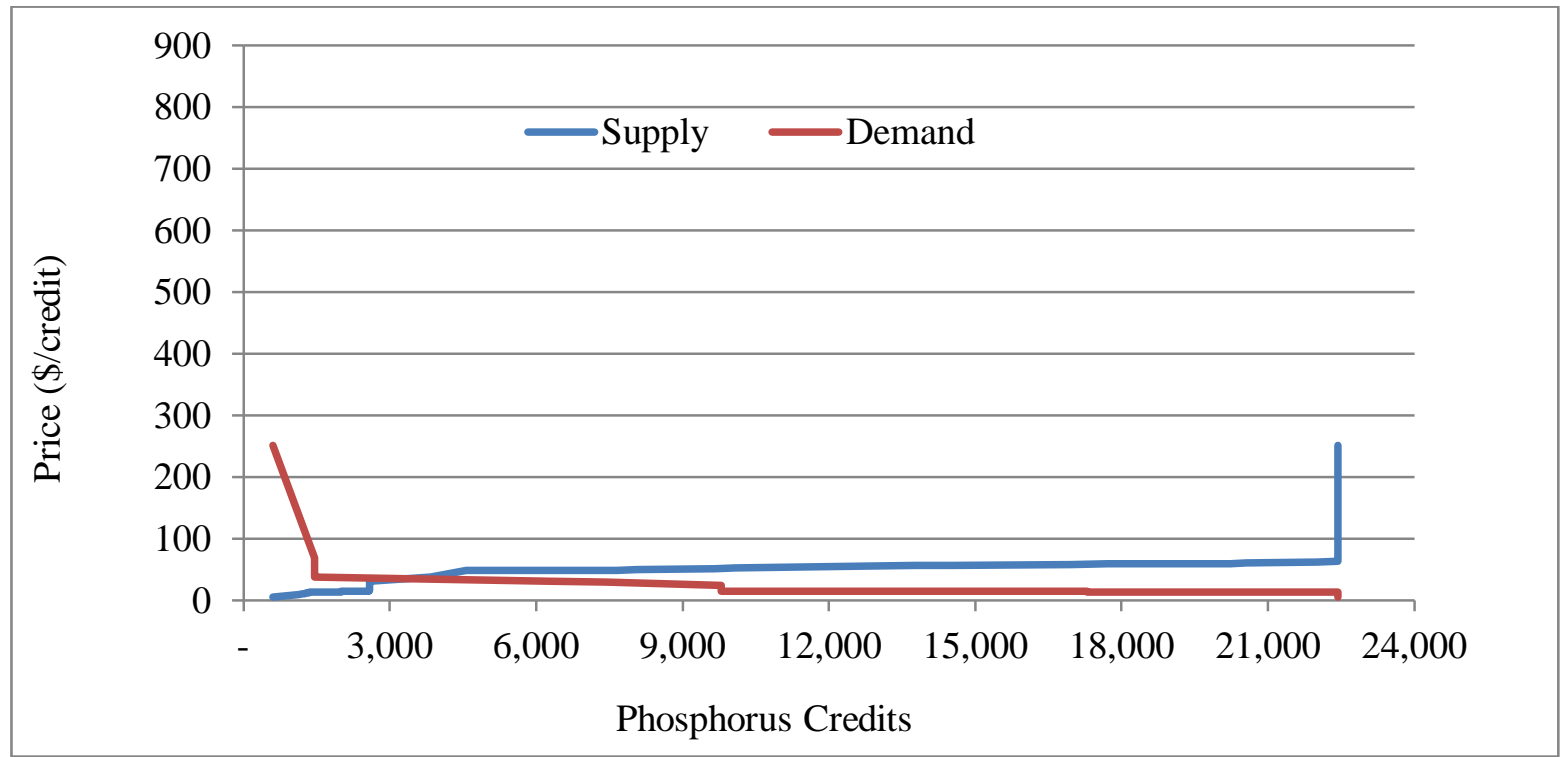

Figure C32: Potential Demand and Supply of TP Credits in a Combined Nutrient Market in Scenario 11 


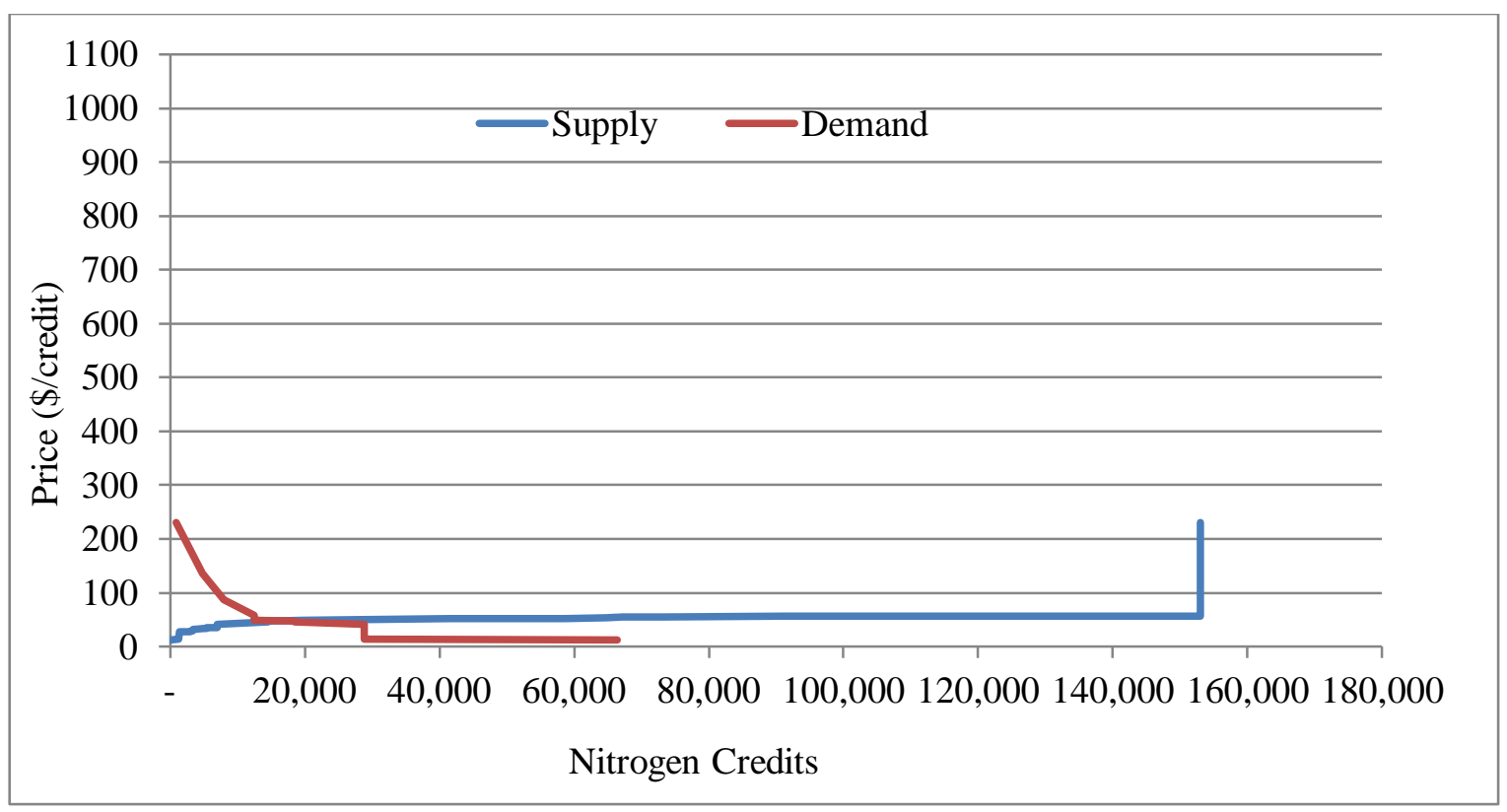

Figure C33: Potential Demand and Supply of TN Credits in a Combined Nutrient Market in Scenario 11

Scenario 12: Trading Ratio (2:1), WWTP's Effluent Limit (3.0 mg/l TN, $0.1 \mathrm{mg} / \mathrm{l} \mathrm{TP})$, and baseline requirement (100\% Nutrient Management Plan

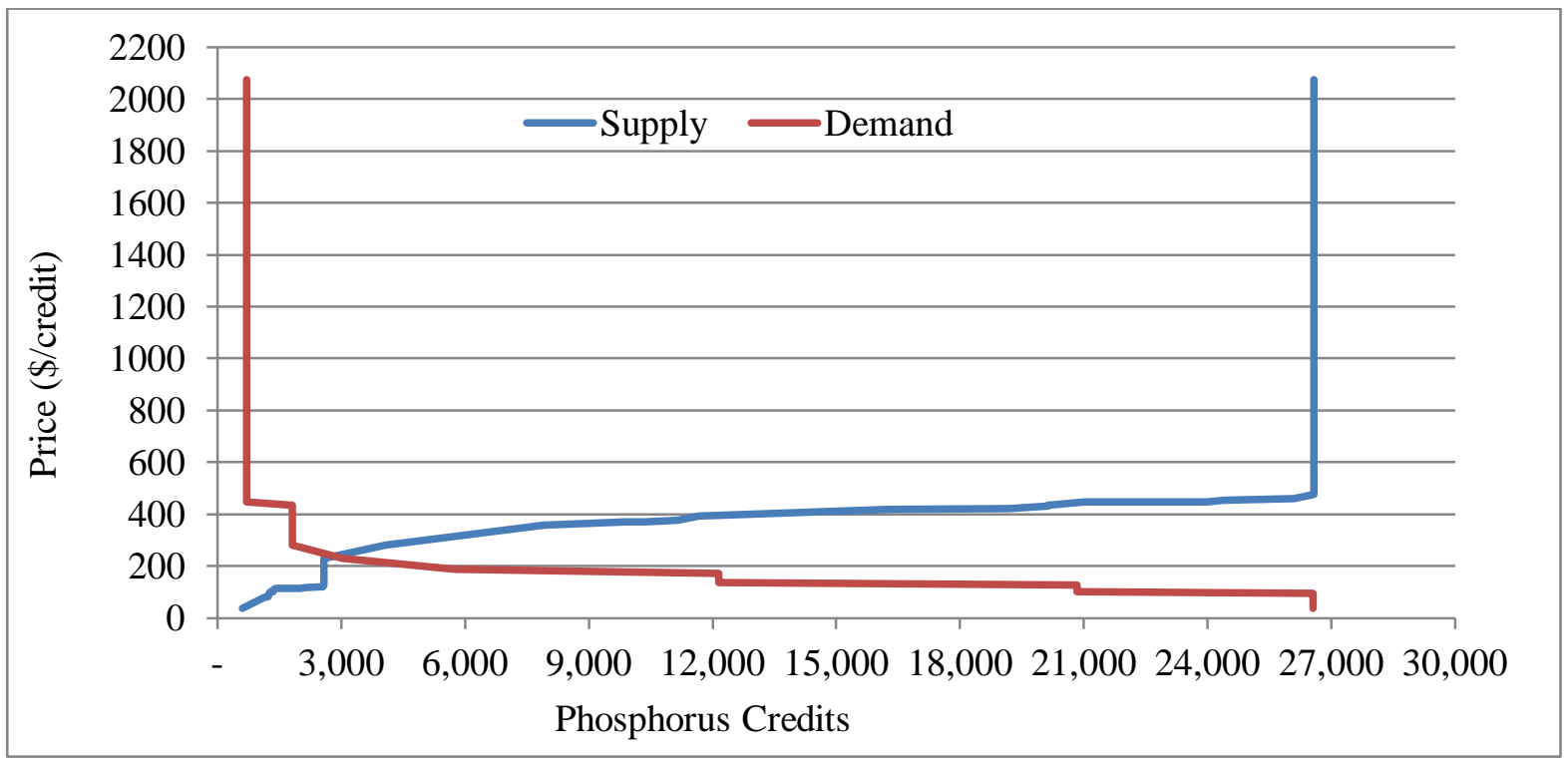

Figure C34: Potential Demand and Supply of TP Credits in a Single Nutrient Market in Scenario 12 


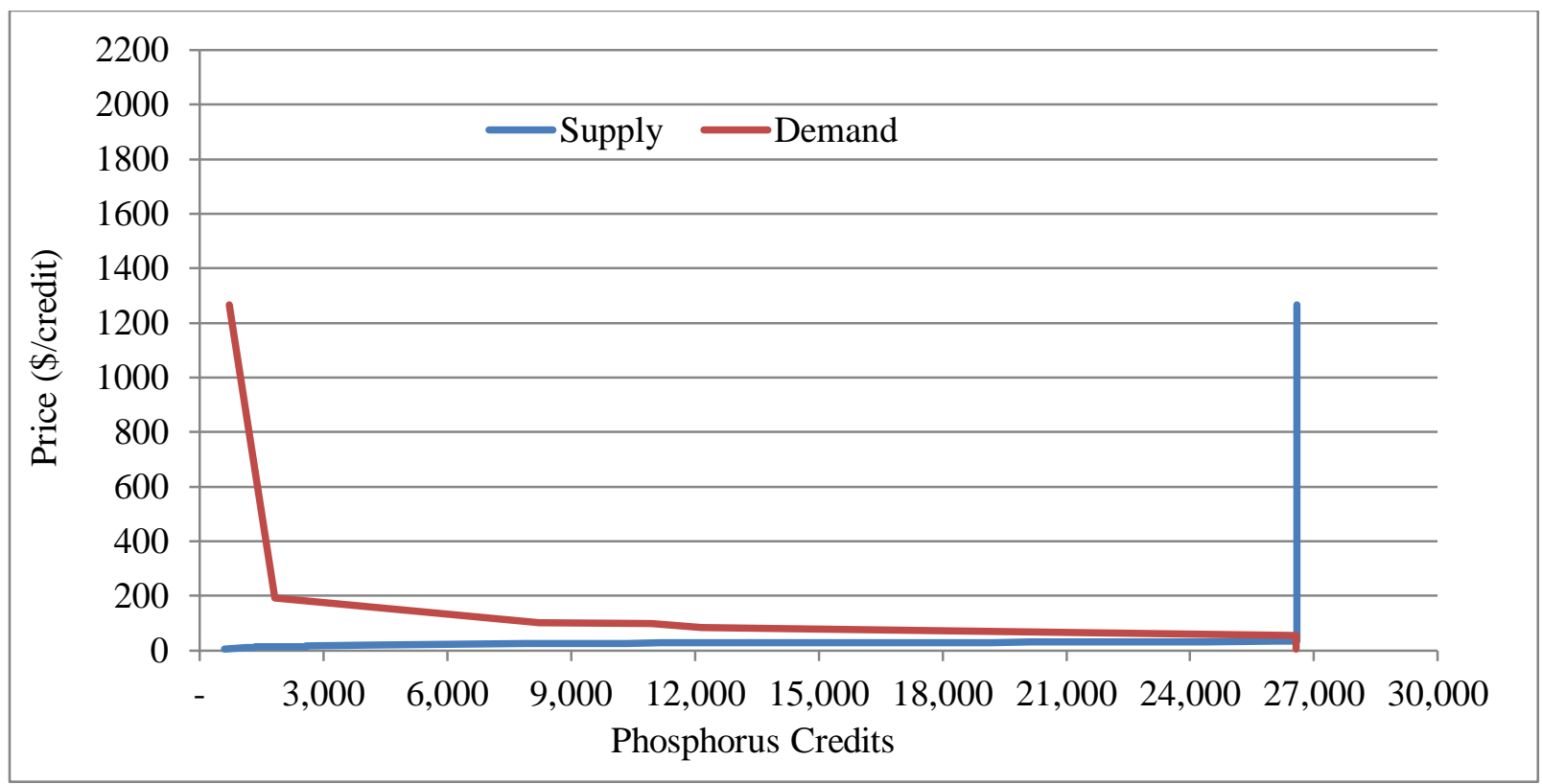

Figure C35: Potential Demand and Supply of TP Credits in a Combined Nutrient Market in Scenario 12

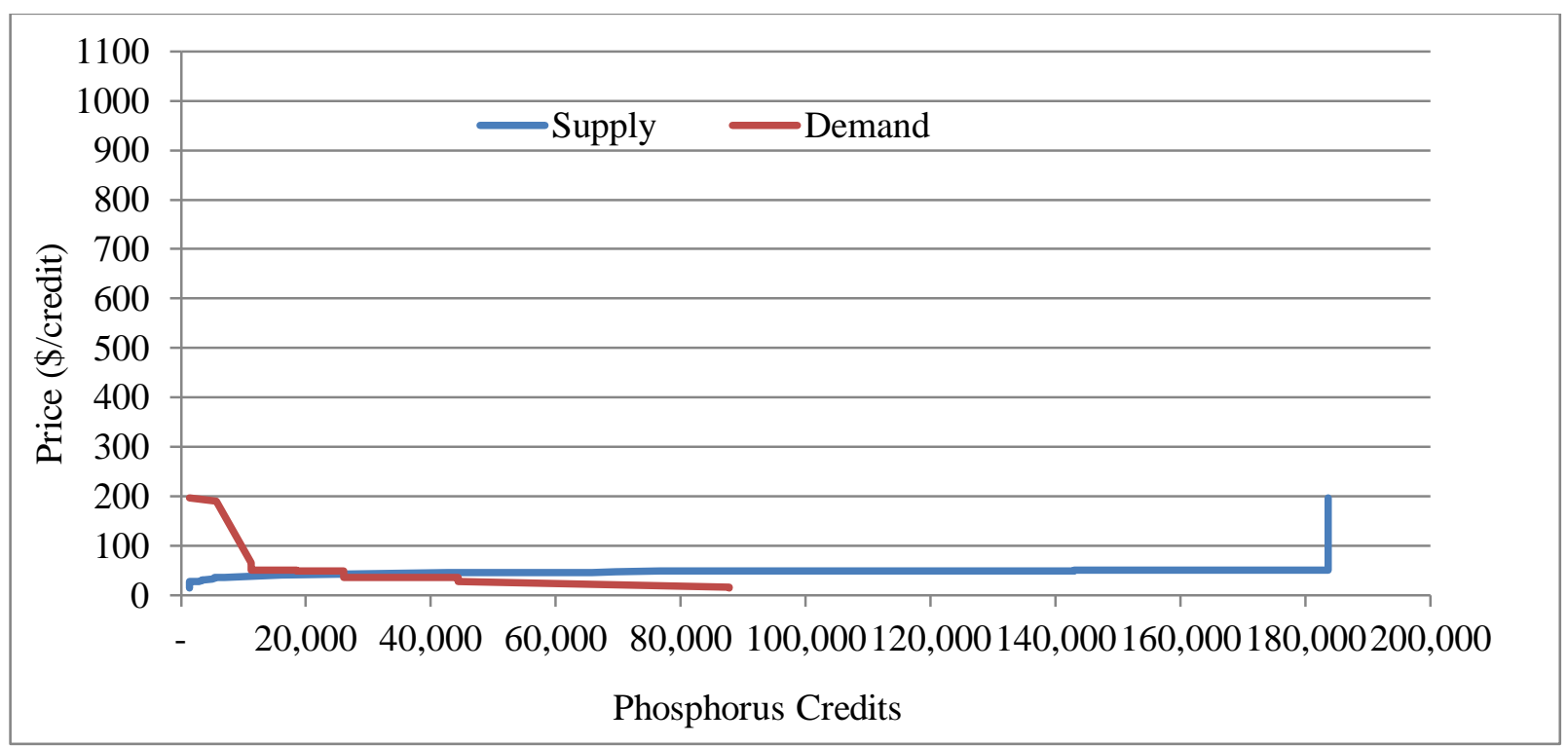

Figure C36: Potential Demand and Supply of TN Credits in a Combined Nutrient Market in Scenario 12 


\title{
APPENDIX D: SURVEY OF FARM BEST MANAGEMENT PRACTICES IN CROP LAND
}

\author{
Survey of Farm Best Management Practices in Crop Land \\ West Virginia University \\ Spring 2011
}

\section{Introduction}

This survey is being conducted as part of a research project about implementation of best management practices by farmers in the Greenbrier Valley Conservation District. This research is part of an effort to assess the feasibility of establishing a nutrient trading program in the Kanawha River basin. All responses are voluntary and you may choose to answer or not answer any of the questions asked. All information collected in this survey will be kept strictly confidential. No information about individual responses will be revealed. For more information about this survey, please contact: Alan Collins, Professor in Agricultural and Resource Economics, West Virginia University, 304-293-5486 or alan.collins@ mail.wvu.edu. There are at most 14 questions to answer in this survey so that it should take less than 10 minutes to complete.

Section A. General Information about Your Farm Operation.

(A1) We are interested in finding out the current management of land described by:

Parcel ID: Area: acres

in Greenbrier County. Please indicate below which choice best describes how this land is managed? (Please check one)

\footnotetext{
$\square$ As owner, I actively manage this land. Please continue to question A2.

The land is currently idle. Please continue to question A2.

$\square$ The land is leased to another farmer and I take an active role in its management. Please continue to question A2.

The land is leased and I am not involved in its management. Please skip to Section D on page 6.

$\square$ Other, please explain:
}

(Please skip to Section D on page 6)

(A2) How would you describe your farm operation? (Please check one)

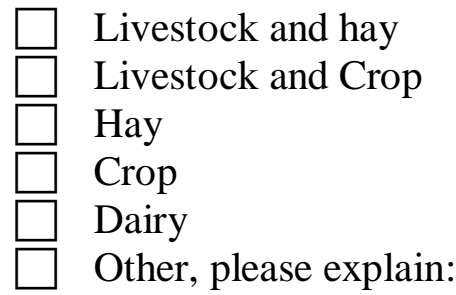


(A3) Based on 2010, about what percentage of your annual household income comes from farming? (Please check one)

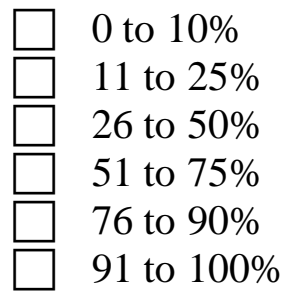

Section B. Best management practices on the parcel (s) described in Question A1 undertaken by you or your lease holder.

(B1) Which of the following best management practices have you (or a tenant) implemented at own expense on the parcel (s) described in Question A1 since January 2000? (Please check all that apply)

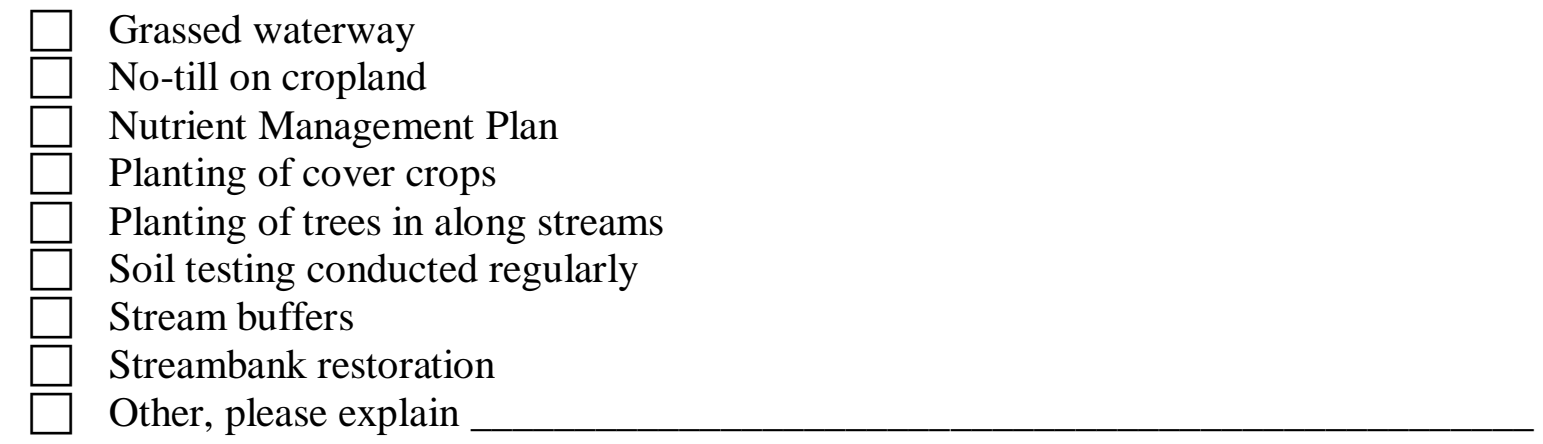

(B2) Which of the following best management practices have you or your tenant implemented with NRCS cost share assistance on the parcel (s) described in Question A1 since January 2000? (Please check all that apply)

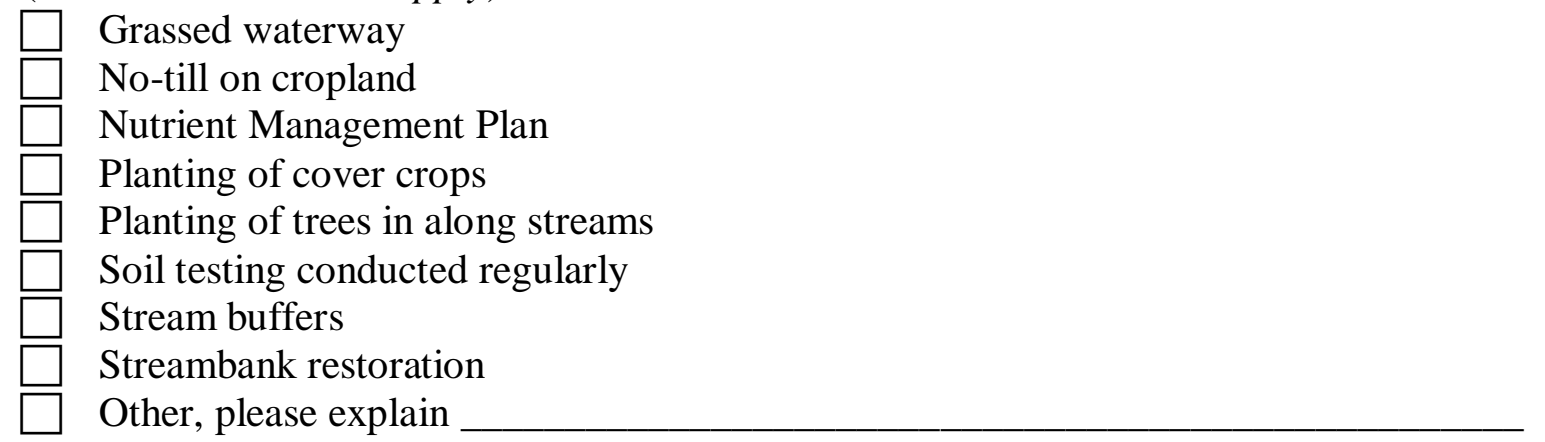


(B3) Please estimate how much of the following best management practices have you (or your tenant) implemented either on your own or with NRCS cost share assistance on the parcel (s) described in Question A1since January 2000? (Please fill in your responses)

\begin{tabular}{|l|r|r|}
\hline \multicolumn{1}{|c|}{ BMP } & On your own cost & With NRCS cost share \\
\hline Grassed waterway & feet & feet \\
\hline No-till on cropland & acres \\
\hline Nutrient Management Plan & acres & acres \\
\hline Planting of cover crops & acres & acres \\
\hline Planting of trees in along streams & acres & stream feet \\
\hline Soil testing regularly & stream feet & how often? \\
\hline Stream buffers & how often? & stream miles \\
\hline Streambank restoration & stream miles & stream feet \\
\hline
\end{tabular}

Other, please explain

(B4) Among this same list of best management practices as in the above three questions, are there any practices that you are interested in implementing on your farm operation but have not had the time and/or money to do yet? (Please check all that apply)

$\begin{array}{ll}\square & \text { Grassed waterway } \\ \square & \text { No-till on cropland } \\ \square & \text { Nutrient Management Plan } \\ \square & \text { Planting of cover crops } \\ \square & \text { Planting of trees in along streams } \\ \square & \text { Soil testing conducted regularly } \\ \square & \text { Stream buffers } \\ \square & \text { Streambank restoration } \\ \square & \text { Other, please explain }\end{array}$

Section C. This section contains questions about your interest in water quality plus nutrient trading and some questions about you. Briefly, nutrient trading involves payments to farmers for implementing best management practices on their farms. Such trades occur when dischargers of nutrients (for example, waste water treatment plants discharging nitrogen and phosphorus into rivers) pay farmers to implement best management practices in order to generate credits for reduced nutrient pollution in streams or rivers. These credits then can be used by dischargers in lieu of reducing their own discharges of nutrients.

(C1) Is there a river or stream running through your property? (Please check one)

No

Yes

(C2) How concerned are you about the quality of water in rivers and streams in your area? (Please check one)

Very concerned

Somewhat concerned

Not concerned at all 
(C3) Prior to receiving this survey, how much did you know about nutrient trading? (Please check one)

$\square$ I knew a lot.

I had some knowledge.

$\square$ I knew very little.

I have never heard of nutrient trading.

(C4) Are you interested in learning more about nutrient trading?

$\square$ No

$\square$ Yes

If your response is Yes, please fill out insert at the back of this survey

(C5) What is your age group?

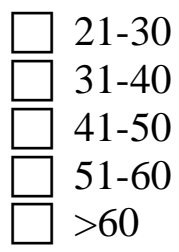

(C6) What is the highest level of education that you completed?

$\square$ Eighth grade or less

$\square$ High school diploma or GED

Technical school

$\square$ College degree

Graduate school

(C7) What was your total household income for 2010?
$\square$ Under $\$ 20,000$
$\$ 21,000$ - $\$ 34,999$
$\$ 35,000$ - $\$ 49,999$
$\$ 50,000-\$ 74,999$
$\$ 75,000$ - $\$ 99,999$
$\$ 100,000$ - $\$ 149,999$
$\$ 150,000$ or more

(C8). Additional Comments:

This is the end of the survey. Thank you for answering these questions. Your time is very much appreciated. 
Section D. This section is for LANDLORDS ONLY who are not actively involved in management of their land. It contains questions related to current land manager's information and your knowledge of best management practices implemented by the current land manager.

(D1) Who is currently managing the land described in Question A1?

Name:

Mailing address:

City, State, Zip:

(D2) Are you aware of best management practices implemented by the lease holder on the parcel (s) described in Question A1since January 2000?

$\square$ No - end of the survey, thank you

$\square$ Yes - Please continue to Question D3

(D3) To the best of your knowledge, which of the following best management practices have implemented on the parcel (s) described in Question A1 since January 2000? (Please check all that apply)

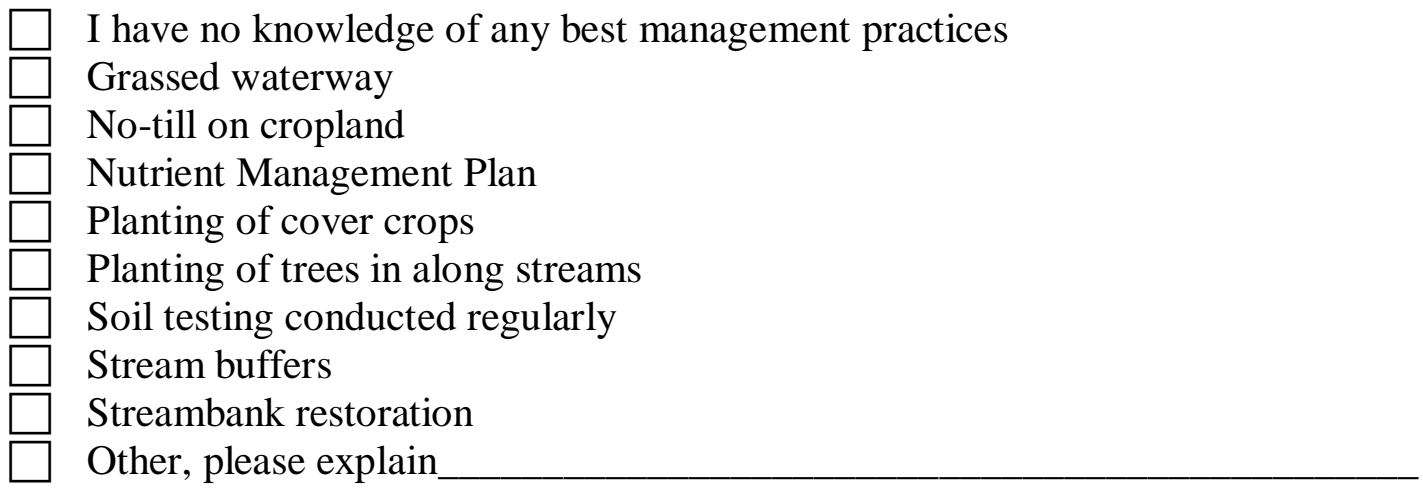

\section{E. Additional Comments:}

This is the end of the survey. Thank you for answering these questions. Your time is very much appreciated. 


\title{
APPENDIX E: SURVEY OF FARM BEST MANAGEMENT PRACTICES IN PASTURE LAND
}

\author{
Survey of Farm Best Management Practices in Pasture Land \\ West Virginia University \\ Spring 2011
}

\section{Introduction}

This survey is being conducted as part of a research project about implementation of best management practices by farmers in the Greenbrier Valley Conservation District. This research is part of an effort to assess the feasibility of establishing a nutrient trading program in the Kanawha River basin. All responses are voluntary and you may choose to answer or not answer any of the questions asked. All information collected in this survey will be kept strictly confidential. No information about individual responses will be revealed. For more information about this survey, please contact: Alan Collins, Professor in Agricultural and Resource Economics, West Virginia University, 304-293-5486 or alan.collins@ mail.wvu.edu. There are at most 14 questions to answer in this survey so that it should take less than 10 minutes to complete.

Section A. General information about your farm operation.

(A1) We are interested in finding out the current management of land described by:

Parcel ID: Area: acres

in Greenbrier County. Please indicate below which choice best describes how this land is managed? (Please check one)

As owner, I actively manage this land. Please continue to question A2.

The land is currently idle. Please continue to question A2.

The land is leased to another farmer and I take an active role in its management. Please continue to question A2.

$\square$ The land is leased and I am not involved in its management. Please skip to Section D on page 6.

Other, please explain:

(Please skip to Section D on page 6)

(A2) How would you describe your farm operation? (Please check one)

Livestock and hay

Livestock and Crop

Hay

Crop

Dairy

Other, please explain: 
(A3) Based on 2010, about what percentage of your annual household income comes from farming? (Please check one)

\begin{tabular}{l}
$\square \quad 0$ to $10 \%$ \\
$\square \quad 11$ to $25 \%$ \\
\hline$\square \quad 26$ to $50 \%$ \\
$\square \quad 51$ to $75 \%$ \\
$\square \quad 76$ to $90 \%$ \\
$\square \quad 91$ to $100 \%$
\end{tabular}

Section B. Best management practices on the parcel (s) described in Question A1 undertaken by you or your lease holder.

(B1) Which of the following best management practices have you (or a tenant) implemented at own expense on the parcel (s) described in Question A1 since January 2000? (Please check all that apply)

Prescribed grazing management

Watering facility

Nutrient management plan

Animal waste storage facility

Fencing of livestock from streams

Planting of trees in along streams

Stream buffers

Streambank restoration

Winter grazing areas away from streams

Other, please explain

(B2) Which of the following best management practices have you or your tenant implemented with NRCS cost share assistance on the parcel (s) described in Question A1 since January 2000? (Please check all that apply)

Prescribed grazing management

Watering facility

Nutrient management plan

Animal waste storage facility

Fencing of livestock from streams

Planting of trees in along streams

Stream buffers

Streambank restoration

Winter grazing areas away from streams

Other, please explain 
(B3) Please estimate how much of the following best management practices have you (or your tenant) implemented either on your own or with NRCS cost share assistance on the parcel (s) described in Question A1since January 2000? (Please fill in your responses)

\begin{tabular}{|l|r|r|}
\hline BMP & On your own cost & With NRCS cost share \\
\hline Prescribed grazing management & feet & feet \\
\hline Watering facility & number & number \\
\hline Nutrient Management Plan & acres & acres \\
\hline Animal waste storage facility & number & number \\
\hline Fencing of livestock from streams & miles & miles \\
\hline Planting of trees in along streams & stream feet & stream feet \\
\hline Stream buffers & stream miles & stream miles \\
\hline Streambank restoration & stream feet & acres feet \\
\hline $\begin{array}{l}\text { Winter grazing areas away from } \\
\text { streams }\end{array}$ & acres & \\
\hline
\end{tabular}

Other, please explain

(B4) Among this same list of best management practices as in the above three questions, are there any practices that you are interested in implementing on your farm operation but have not had the time and/or money to do yet? (Please check all that apply)

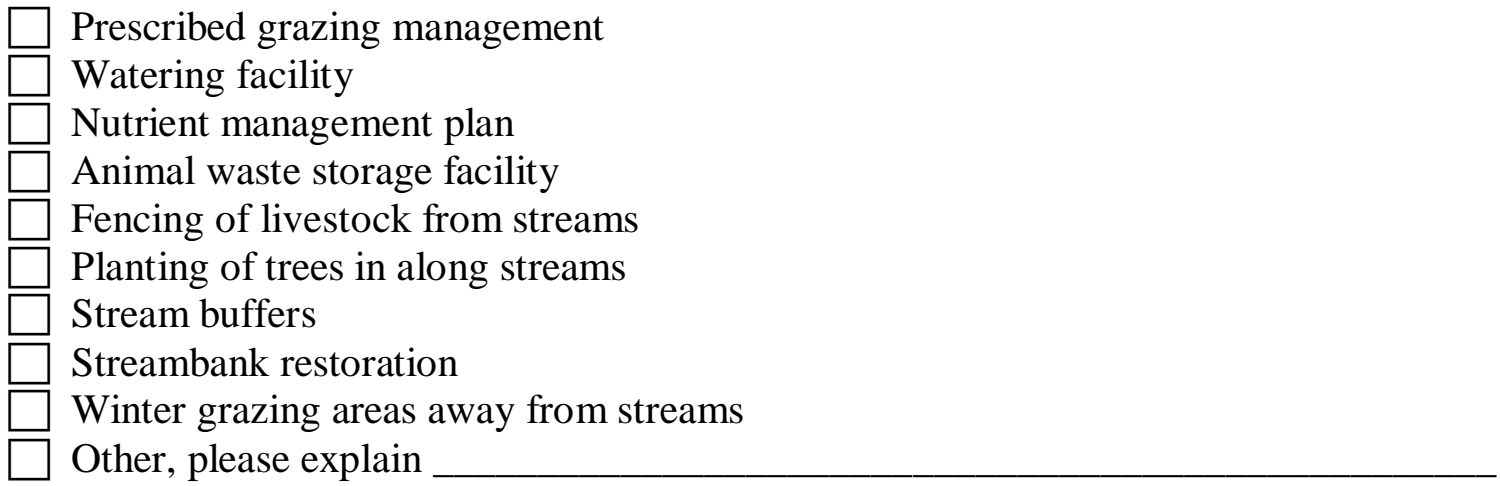

Section C. This section contains questions about your interest in water quality plus nutrient trading and some questions about you. Briefly, nutrient trading involves payments to farmers for implementing best management practices on their farms. Such trades occur when dischargers of nutrients (for example, waste water treatment plants discharging nitrogen and phosphorus into rivers) pay farmers to implement best management practices in order to generate credits for reduced nutrient pollution in streams or rivers. These credits then can be used by dischargers in lieu of reducing their own discharges of nutrients.

(C1) Is there a river or stream running through your property? (Please check one)

No

Yes 
(C2) How concerned are you about the quality of water in rivers and streams in your area? (Please check one)

$\square$ Very concerned

Somewhat concerned

Not concerned at all

(C3) Prior to receiving this survey, how much did you know about nutrient trading? (Please check one)

$\square$ I knew a lot.

I had some knowledge.

I knew very little.

I have never heard of nutrient trading.

(C4) Are you interested in learning more about nutrient trading?

$\square$ No

Yes

If your response is Yes, please fill out insert at the back of this survey

(C5) What is your age group?
21-30
$31-40$
41-50
$51-60$
$>60$

(C6) What is the highest level of education that you completed?

$\square$ Eighth grade or less

High school diploma or GED

Technical school

$\square$ College degree

Graduate school

(C7) What was your total household income for 2010?

$\square$ Under $\$ 20,000$

$\$ 21,000-\$ 34,999$

$\$ 35,000-\$ 49,999$

$\$ 50,000-\$ 74,999$

$\$ 75,000$ - $\$ 99,999$

$\$ 100,000$ - $\$ 149,999$

$\$ 150,000$ or more

(C8). Additional Comments:

This is the end of the survey. Thank you for answering these questions. Your time is very much appreciated. 
Section D. This section is for LANDLORDS ONLY who are not actively involved in management of their land. It contains questions related to current land manager's information and your knowledge of best management practices implemented by the current land manager.

(D1) Who is currently managing the land described in Question A1?

Name:

Mailing address:

City, State, Zip:

(D2) Are you aware of best management practices implemented by the lease holder on the parcel (s) described in Question A1since January 2000?

$$
\begin{aligned}
& \square \quad \text { No - end of the survey, thank you } \\
& \square \quad \text { Yes - Please continue to Question D3 }
\end{aligned}
$$

(D3) To the best of your knowledge, which of the following best management practices have implemented on the parcel (s) described in Question A1 since January 2000? (Please check all that apply)

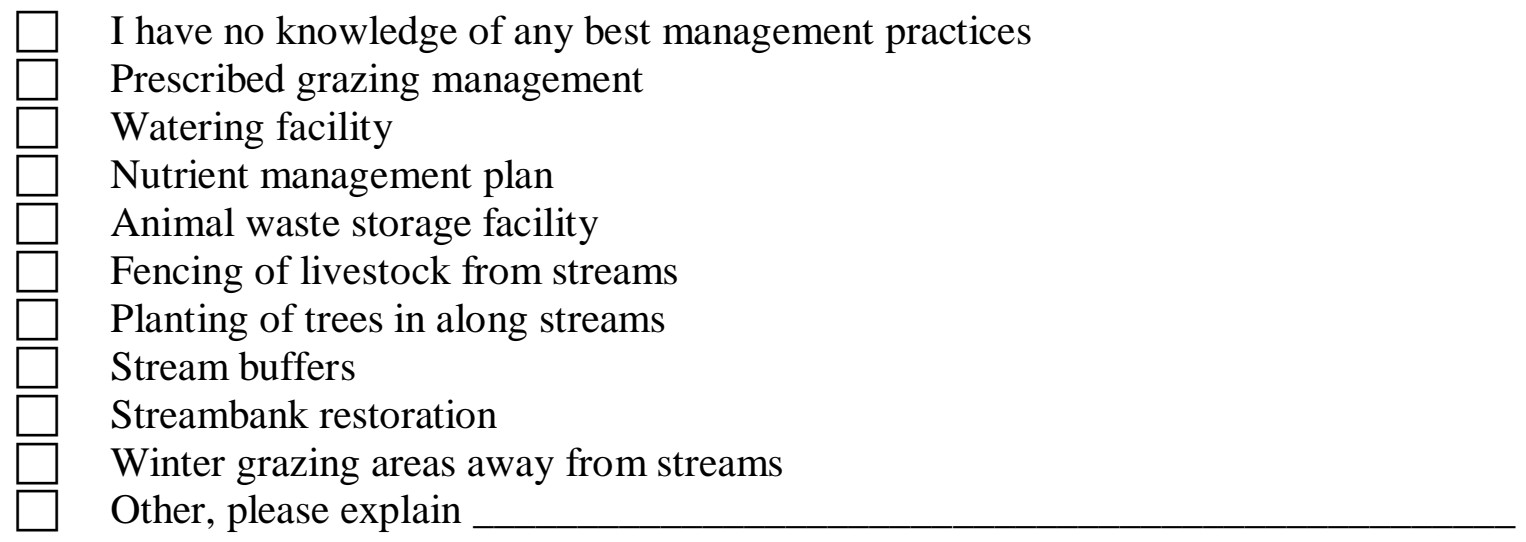

\section{E. Additional Comments:}

This is the end of the survey. Thank you for answering these questions. Your time is very much appreciated. 